FABRIZZIO RODRIGUES COSTA

Caracterização tecnológica do minério de ouro da Mina Morro do Ouro - Paracatu, MG 


\section{FABRIZZIO RODRIGUES COSTA}

Caracterização tecnológica do minério de ouro da Mina Morro do Ouro - Paracatu, MG

Dissertação apresentada à Escola

Politécnica da Universidade de São Paulo

para obtenção do título Mestre em

Ciências

São Paulo

2016 


\section{FABRIZZIO RODRIGUES COSTA}

Caracterização tecnológica do minério de ouro da Mina Morro do Ouro - Paracatu, MG

Dissertação apresentada à Escola

Politécnica da Universidade de São Paulo para obtenção do título Mestre em Ciências

Área de Concentração:

Engenharia Mineral

Orientador:

Prof. Dr. Henrique Kahn 
Este exemplar foi revisado e alterado em relação à versão original, sob responsabilidade única do autor e com a anuência de seu orientador.

São Paulo, 15 de março de 2016.

Assinatura do autor

Assinatura do orientador

Catalogação-na-publicação

Costa, Fabrizzio Rodrigues

Caracterização tecnológica do minério de ouro da Mina Morro do Ouro - Paracatu, MG / F. R. Costa - versão corr. São Paulo, 2016.

148 p.

Dissertação (Mestrado) - Escola Politécnica da Universidade de São Paulo. Departamento de Engenharia de Minas e de Petróleo.

1. Caracterização tecnológica de minérios 2. Minérios auríferos 3. Análise de imagens automatizada 4. Microscopia eletrônica de varredura I. Universidade de São Paulo. Escola Politécnica. Departamento de Engenharia de Minas e de Petróleo II. $t$. 


\section{DEDICATÓRIA}

Dedico esse texto à minha família que me acompanhou nessa jornada.

Ariane, Wilson, Ana Clara e Henrique....amo vocês. 


\section{AGRADECIMENTOS}

Agradeço ao meu orientador Prof. Dr. Henrique Kahn pela oportunidade de realizar este trabalho, pela paciência e dedicação à pesquisa. A Profa. Dra. Carina Ulsen, Dra. Manuela Tassinari e Dra. Giuliana Ratti pelos ensinamentos.

Aos meus amigos do LCT que sempre estiveram de prontidão para ajudar. Aos técnicos Juscelino, Erílio, Ingled e Fernanda, aos geólogos Daniel Uliana, Juliana Antoniassi, Sheila Schuindt, Renato Contessotto, ao engenheiro de minas Guilherme Nery e os químicos Saulo Colenci e Paulo Feldbaum. Dedico também aos amigos Daniel Bortoleto e toda a turma da Geologia USP de 2000.

Agradeço à empresa Kinross Brasil Mineração por possibilitar a realização deste estudo por meio do fornecimento das amostras em especialmente para aos amigos da Gerência de Serviços Técnicos; Eldrick Esper, Reginaldo Rugolo, Luis Fernando e Wardan Martins pela inestimável ajuda e contribuição.

E finalmente, agradeço a minha esposa Ariane e aos meus pais, Adão e Iracema, pela confiança, dedicação e carinho. Aos meus irmãos, Ludmilla e Jerryson pelo apoio. Serei eternamente grato a vocês! 
"O mestre disse a um dos seus alunos: Yu, queres saber em que consiste o conhecimento? Consiste em ter consciência tanto de conhecer uma coisa quanto de não a conhecer. Este é o conhecimento".

(Confúcio) 


\section{RESUMO}

As unidades de beneficiamento de minério de ouro buscam cada vez mais uma produção de baixo custo e maximização dos ganhos financeiros. A caracterização tecnológica está inserida em uma abordagem multidisciplinar que permite agregar conhecimento, alternativas de otimização e redução nos custos de operação.

Inserida como uma ferramenta na caracterização tecnológica, a análise de imagens automatizada tem importante papel no setor mineral principalmente pela rapidez das análises, robustez estatística e confiabilidade nos resultados. A técnica pode ser realizada por meio de imagens adquiridas em microscópio eletrônico de varredura, associada a microanálises químicas sendo utilizada em diversas etapas de um empreendimento mineiro.

Este estudo tem como objetivo a caraterização tecnológica de minério de ouro da Mina Morro do Ouro, Minas Gerais na qual foi utilizado a técnica de análise de imagens automatizada por MLA em um conjunto de 88 amostras.

Foi possível identificar que $90 \%$ do ouro está na fração acima de $0,020 \mathrm{~mm}$; o quartzo e mica representam cerca de $80 \%$ da massa total do minério; os sulfetos apresentam diâmetro de círculo equivalente entre 80 e 100 um e são representados por pirita e arsenopirita, com pirrotita, calcopirita, esfalerita e galena subordinada.

Também foi possível observar que o ouro está majoritariamente associado à pirita e arsenopirita e com o aumento de teor de arsênio, cresce a parcela de ouro associado à arsenopirita. As medianas das distribuições de tamanho dos grãos de ouro apresentam um valor médio de $19 \mu \mathrm{m}$. Verificou-se que a composição dos grãos de ouro é bastante diversa, em média $77 \%$ de ouro e $23 \%$ de prata.

Para material abaixo de $0,50 \mathrm{~mm}$ observa-se uma parcela expressiva de perímetro exposto dos grãos de ouro (média $73 \%$ ); o ouro incluso (21\% do total dos grãos de ouro) está associado a pirita e arsenopirita, sendo que em 14 das 88 amostras este valor pode superar $40 \%$ do total de ouro contido.

A ferramenta da análise de imagens automatizada mostrou-se bastante eficiente definindo características particulares o que fornece de forma objetiva subsídios para os trabalhos de planejamento de mina e processamento mineral.

Palavras-chave: análise quantitativa de imagens; minério de ouro; arsenopirita 


\section{ABSTRACT}

Evolution in gold ore processing units are increasingly focused towards efficiency seeking routines, leading to a low-cost and maximal financial gain. The mineral characterization, inserted into a multidisciplinary approach enables a knowledge adding dynamics that results in optimization alternatives and consequent operating cost reduction.

Being one of commonly used tools in mineral characterization, automated image analysis plays an important role in the mining sector mainly due to its rapid analysis, statistical robustness and reliability of the results. The technique can be performed using images acquired in a scanning electron microscope, usually associated with chemical microanalysis having applications in different stages of a mining venture.

The following study aims to produce a mineral characterization using an automated image analysis technique by MLA in a set of 88 samples from the Morro do Ouro gold mine, located in Minas Gerais State, Brazil.

Results showed that $90 \%$ of gold content is above the $0,02 \mathrm{~mm}$ size fraction; quartz and mica are the mayor mineral phases identified representing roughly $80 \%$ of the total; sulfides have equivalent circle diameter ranging from 80 to $100 \mu \mathrm{m}$ present mainly as pyrite and arsenopyrite.

It was also noted that gold is mainly associated with pyrite and arsenopyrite and that there is a correlation between the higher share of gold associated with arsenopyrite as a function of higher contents in arsenic. The median size distributions of gold grains have an average of $19 \mu \mathrm{m}$. It was found that the composition of the gold is highly diverse, on average $77 \%$ gold and $23 \%$ silver.

For material below $0.50 \mathrm{~mm}$, was observed that a significant portion of the exposed gold grains circumference (average $73 \%$ ); the included gold (21\% of total grains of gold) is associated with pyrite and arsenopyrite, and that in 14 of 88 samples this value may exceed $40 \%$ of the gold contained.

The automated image analysis tool proved to be very efficient defining particular features, which provides an objective subsidy for mine planning work and mineral processing.

Keywords: automated image analysis; gold ore; arsenopyrite 


\section{LISTA DE ILUSTRAÇÕES}

página

Figura 2.1 - Esquema dos ambientes de formação dos depósitos de ouro 21

Figura 2.2 - Produção de ouro em escala industrial e garimpeira $(1988$ - 2014) .....28

Figura 2.3 - Cotação média anual do preço do ouro (1968 - 2014) 30

Figura 2.4 - Recuperação de ouro em relação ao tamanho do grão 34

Figura 2.5 - Partícula binária seccionada em distintas regiões .42

Figura 2.6 - Esquema geral de classificação no MLA .45

Figura 2.7 - Ilustração do fenômeno de difração de raios $X$ 49

Figura 2.8 - Mapa Geológico da Faixa Brasília 52

Figura 2.9 - Coluna estratigráfica dos grupos Canastra, Vazante e Ibiá 53

Figura 2.10 - Amostras do depósito Morro do Ouro .54

Figura 2.11 - Seção esquemática do depósito Morro do Ouro indicando horizontes mineralizados. .55

Figura 2.12 - Seção esquemática do corpo de minério tipo B2 .57

Figura 2.13 - Fluxograma da usina de processamento I .59

Figura 2.14 - Fluxograma da usina de processamento II - Cominuição 60

Figura 2.15 - Fluxograma da usina de processamento II - Flotação 61

Figura 3.1 - Amostragem de testemunho de sondagem 65

Figura 3.2 - Amostragem na de frente de lavra.... 66

Figura 3.3 - Fluxograma das atividades realizadas 67

Figura 3.4 - Aspecto geral das amostras estudadas - amostra tal qual. 68

Figura 3.5 - Equipamentos utilizados para cominuição e divisão da amostra 68

Figura 3.6 - Peneirador Haver EML 450 utilizado no peneiramento a úmido ..... 69

Figura 3.7 - Procedimento de separação por líquidos densos e equipamento. .71

Figura 3.8 - Equipamentos utilizados para difração de raios $X$ 72

Figura 3.9 - Equipamentos utilizados para divisão da amostra .73

Figura 3.10 - Procedimento de coleta e processamento dos dados - MLA. 74

Figura 4.1 - Relação entre teores de arsênio e ouro - banco de dados da Kinross..78 
Figura 4.2 - Relação entre teores de enxofre e ouro - banco de dados da Kinross ..79 Figura 4.3 - Correlação entre teores de enxofre, arsênio e ouro nas amostras estudadas.

Figura 4.4 - Distribuição de massa para peneiramento em 0,020 mm.... .82

Figura 4.5 - Distribuição de enxofre para peneiramento em 0,020 mm .83

Figura 4.6 - Distribuição de arsênio para peneiramento em 0,020 mm. .83

Figura 4.7 - Distribuição de ouro para peneiramento em 0,020 mm .84

Figura 4.8 - Distribuição em massa para separações em líquido denso (fração$0,50+0,020 \mathrm{~mm})$

Figura 4.9 - Distribuição de enxofre para separações em líquido denso (fração $0,50+0,020 \mathrm{~mm})$

Figura 4.10 - Distribuição de arsênio para separações em líquido denso (fração $0,50+0,020 \mathrm{~mm})$

Figura 4.11 - Distribuição de ouro para separações em líquido denso (fração $0,50+0,020 \mathrm{~mm})$.

Figura 4.12 - Sobreposições dos difratogramas de raios $X$ das amostras estudadas

Figura 4.13 - Composição mineralógica das amostras estudadas (fração -0,50+0,020 $\mathrm{mm})$. .90

Figura 4.14 - Composição normalizada dos sulfetos (fração -0,50+0,020mm) .91

Figura 4.15 - Distribuição de enxofre entre os principais sulfetos (fração -0,50+0,020 $\mathrm{mm})$.

Figura 4.16 - Correlação entre sulfetos na amostra e teor de enxofre (fração $0,50+0,020 \mathrm{~mm})$

Figura 4.17 - Medianas das distribuições de tamanho de grãos de ouro (D50; ECD) 94 Figura 4.18 - Medianas das distribuições de tamanho para clusters de sulfetos (D50; ECD)

Figura 4.19 - Associação dos grãos de ouro por perímetro de contato - acessível, não encapsulado e incluso (produto afundado, fração -0,50+0,020 mm) .96 
Figura 4.20 - Associação dos grãos de ouro por perímetro de contato (produto

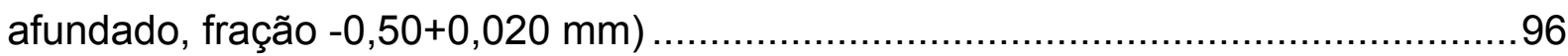

Figura 4.21 - Composição média estimada dos grãos de ouro ……..........................99

Figura 4.22 - Composição média estimada dos grãos de ouro e sua relação com o diâmetro de círculo equivalente do ouro 100

Figura 5.1 - Distribuição mineralógica dos sulfetos nas amostras - classes de teor de arsênio (\% massa; fração $-0,50+0,020 \mathrm{~mm}$ ) 105

Figura 5.2 - Distribuição de enxofre nos sulfetos - teores de arsênio por classe....106 Figura 5.3 - Distribuição acumulada abaixo - tamanho dos grãos de ouro por classe de teor de arsênio (\%) 107

Figura 5.4 - Distribuição granulométrica dos sulfetos por faixa de teor de arsênio fração $-0,5+0,020 \mathrm{~mm}$ 108

Figura 5.5 - Distribuição da associação mineral por perímetro de contato - associação do ouro com os principais minerais - fração -0,50+0,020 mm 110

Figura 5.6 - Perímetro exposto das partículas de sulfetos - fração -0,50+0,020 mm 111

Figura 5.7 - Associação mineral por perímetro de contato - Sulfetos totais; fração $0,50+0,020 \mathrm{~mm}$

Figura 5.8 - Ouro acessível, não encapsulado e incluso determinados a partir dos perímetros de contato dos grãos de ouro (produto afundado; fração $-0,50+0,020 \mathrm{~mm}$ )

Quadro 2.1 - Principais depósitos de ouro de escala mundial 22

Quadro 2.2 - Tipos de minérios auríferos, modo de ocorrência e exemplos 31

Quadro 2.3 - Principais trabalhos relacionados ao depósito Morro do Ouro 63

Quadro 3.1 - Condição de coleta dos difratogramas .72

Fotomicrografia 2.1 - llustração sobre a acessibilidade do ouro 46

Fotomicrografia 2.2 - Ouro potencialmente não extraído - 2D .48 
Fotomicrografia 4.1 - Detalhe de grãos de ouro observados no MEV/EDS - produto afundado, fração $-0,50+0,020 \mathrm{~mm}$

\section{LISTA DE TABELAS}

Tabela 2.1 - Reservas minerais de ouro por unidade de federação. 27

Tabela 2.2 - Principais empresas produtoras de ouro em 2012, incluindo garimpo ..29

Tabela 2.3 - Principais minerais, compostos e conteúdo de ouro 33

Tabela 2.4 - Principais técnicas analíticas para análise de ouro .40

Tabela 3.1 - Composição e densidade dos principais minerais presentes no depósito Morro do Ouro. 70

Tabela 3.2 - Propriedades dos grãos de ouro a partir do perímetro de contato (modelo de extração dos dados do MLA - grain properties)... .76

Tabela 4.1 - Medianas das distribuições de tamanho de sulfetos (D50 - $\mu \mathrm{m}$; ECD) nas amostras estudadas .93

Tabela 4.2 - Sumário das associações dos grãos de ouro por perímetro de contato (produto afundado, fração $-0,50+0,020 \mathrm{~mm}$ ). 97

Tabela 5.1 - Relação das amostras classificadas 102

Tabela 5.2 - Análise granulométrica, teores e distribuição de ouro, arsênio e enxofre para as classes de minério. 103

Tabela 5.3 - Sumário comparativo das separações minerais por liquido denso (TBE $2,95 \mathrm{~g} / \mathrm{cm}^{3}$ ) 104

Tabela 5.4 - Associação mineral de grãos de ouro por perímetro de contato para as classes de minério (fração $-0,5+0,020 \mathrm{~mm}$ ) . 110 


\section{LISTA DE ABREVIATURAS E SIGLAS}

BSE backscattered electrons - elétrons retroespallhados

BWI $\quad$ work index de Bond

CFEM compensação financeira pela exploração de minérios

CIC carvão em coluna

CIL carvão em lixiviação

CIP carvão em polpa

$\mathrm{cm}^{3} \quad$ centímetro(s) cúbico(s)

CSF $\quad$ Cráton do São Francisco

d50 diâmetro médio na qual $50 \%$ das partículas estão abaixo da fração

DNPM Departamento Nacional de Produção Mineral

EDS energy dispersive spectroscopy - espectrômetro de energia dispersiva

FBM Faixa Brasília Meridional

FBS Faixa Brasília Setentrional

GSB Greenstone belts

g gramas

IBRAM Instituto Brasileiro de Mineração

IOCG Iron Oxide Copper Gold

$\mathrm{kg} \quad$ quilogramas

Ma milhões de anos

MEV microscópio eletrônico de varredura

MLA Mineral Liberation Analyser

Mt milhões de toneladas $-10^{6}$ toneladas

Mt/a milhões de toneladas por ano

$\mathrm{Oz} \quad$ unidade de medida ouro em onças

ppb partes por bilhão

ppm partes por milhão

QEMSCAN Quantitative evaluation of minerals by scanning electron microscopy

ROM Run of mine - movimentação de minério da mina

SAG moagem semiautógena 


$\begin{array}{ll}\text { SedEx } & \text { depósitos sedimentares exalativos } \\ \text { SPL_LT } & \text { Sparse Phase Liberation Analysis } \\ \mathrm{t} & \text { toneladas } \\ \text { US\$ } & \text { unidade monetária norte americana } \\ \text { VMS } & \text { depósitos sulfetos maciços vulcanogênicos } \\ \text { XBSE } & \text { Extended BSE Liberation Analysis } \\ \text { WAD } & \text { weak acid dissociable cyanide } \\ \text { Mm } & \text { micrômetro }\end{array}$




\section{SUMÁRIO}

página

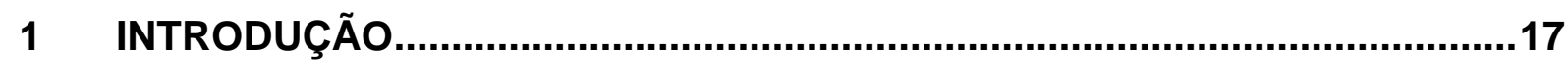

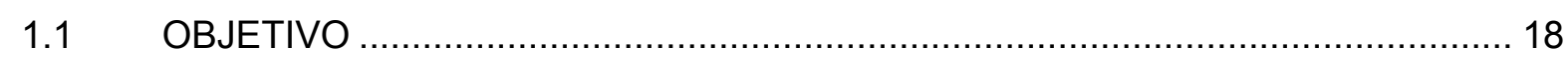

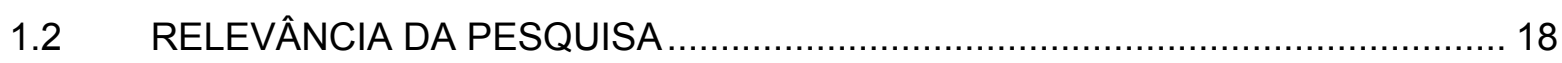

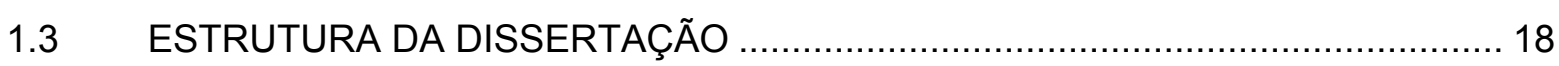

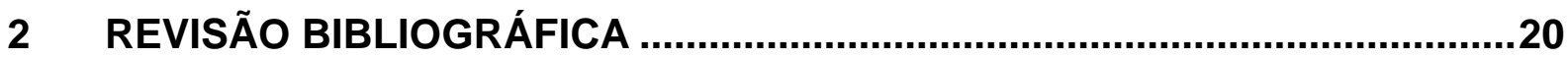

2.1 CONSIDERAÇÕES SOBRE OS DEPÓSITOS DE OURO .................................. 20

2.1.1 Modelo metalogenético do depósito do Morro do Ouro .....................................25

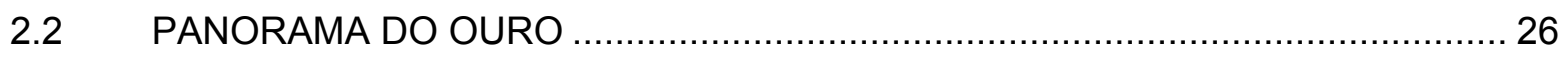

2.2.1 Evolução dos preços no mercado nacional e internacional .................................29

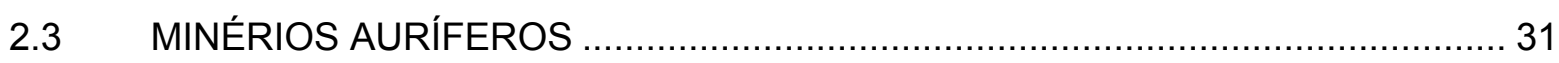

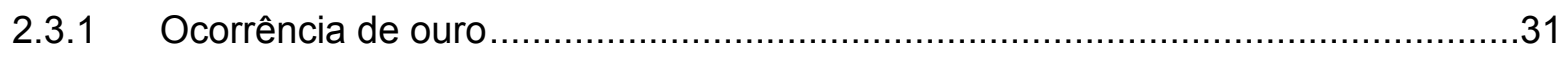

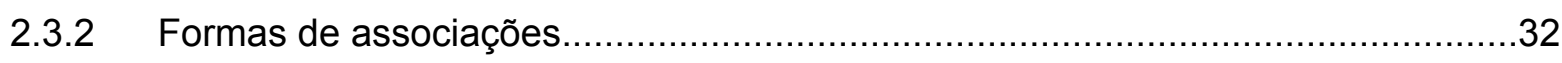

2.3.3 Fatores que afetam a extração do ouro .........................................................33

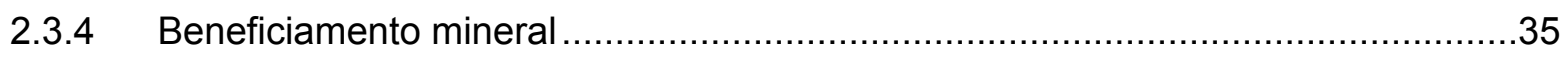

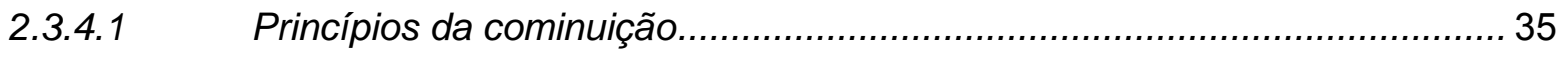

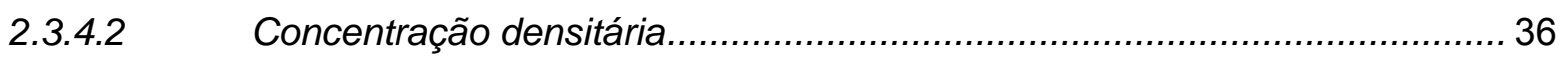

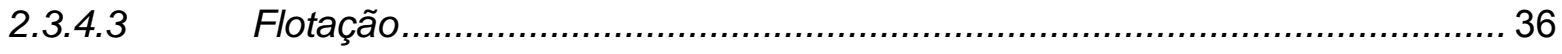

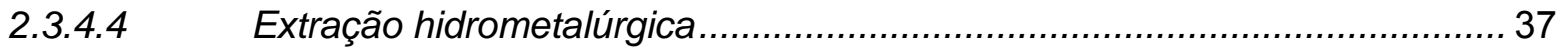

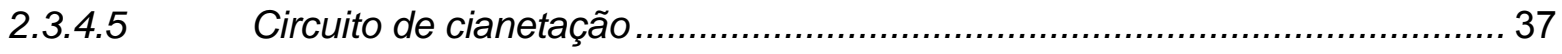

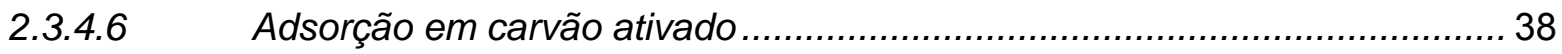

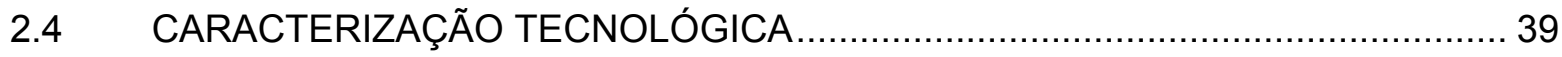

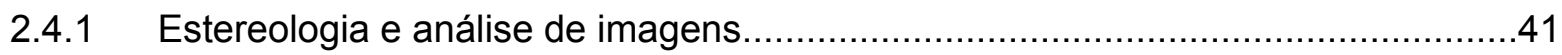

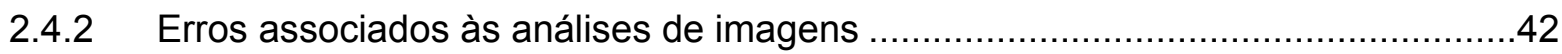

2.4.3 Microscopia eletrônica de varredura e mineralogia quantitativa automatizada......43

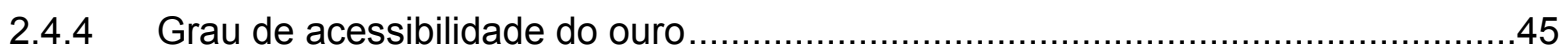

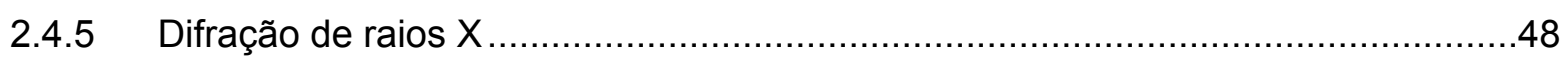

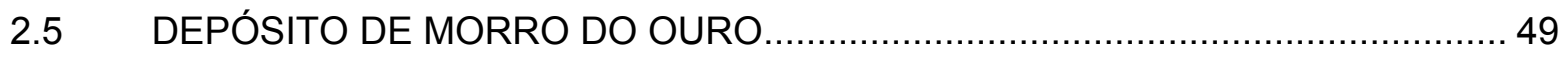

2.5.1 Histórico da exploração de ouro no Morro do Ouro ............................................49

2.5.2 Enquadramento geológico-geotectônico .........................................................51

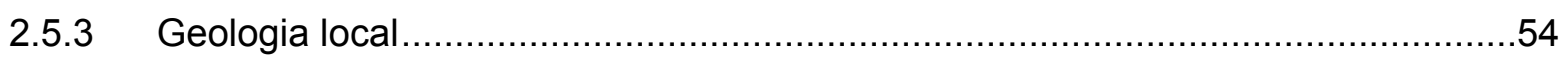




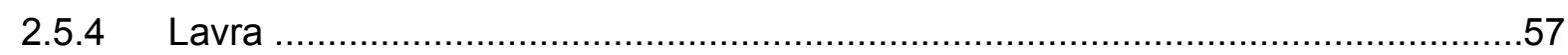

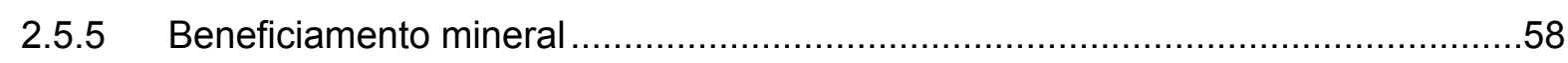

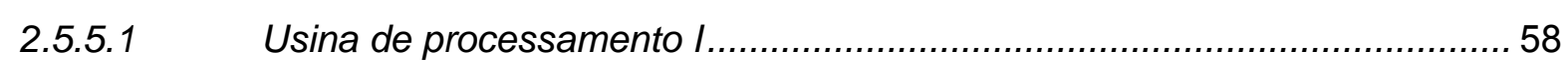

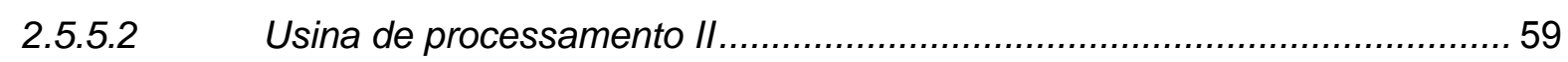

2.5.6 Trabalhos sobre caracterização do minério do Morro do Ouro ...............................62

3 MATERIAIS E MÉTODOS.......................................................................65

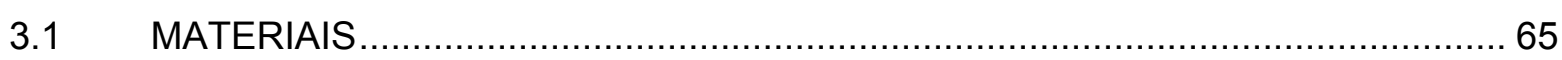

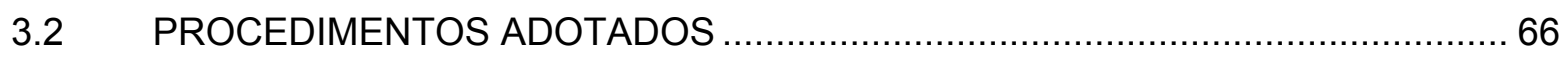

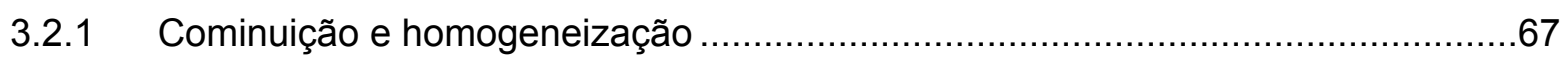

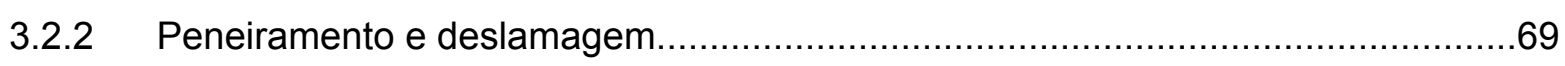

3.2.3 Separações minerais em líquidos densos .......................................................69

3.2.4 Difração de raios $X$ e análises químicas ...........................................................

3.3 CARACTERIZAÇÃO MINERALÓGICA E ASSOCIAÇÕES .................................. 73

3.4 CÁLCULO DAS ASSOCIAÇÕES DOS GRÃOS DE OURO EM PERÍMETRO DE

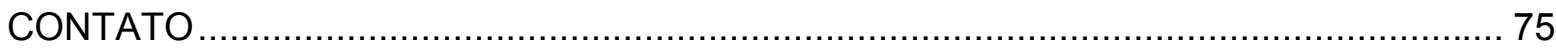

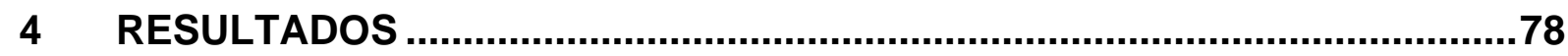

4.1 CORRELAÇÕES QUÍMICAS A PARTIR DO BANCO DE DADOS ANALÍTICO ... 78

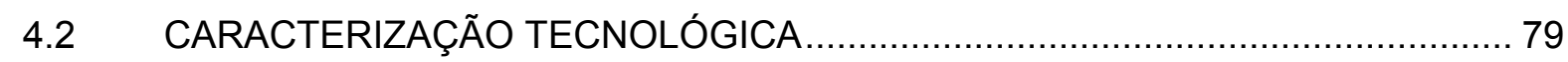

4.2.1 Composição química das amostras estudadas ................................................79

4.2.2 Correlação entre teores nas amostras estudadas................................................80

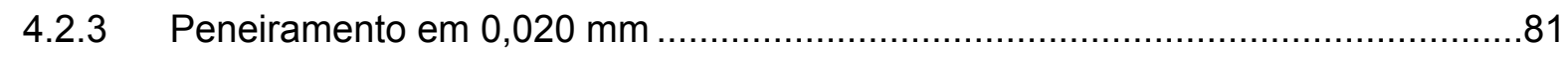

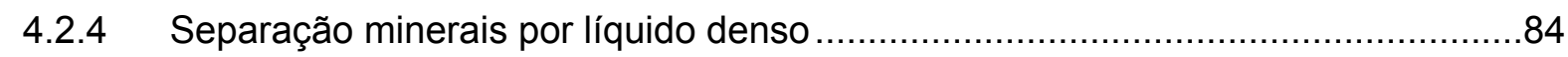

4.2.5 Composição mineralógica das amostras estudadas .............................................88

4.2.6 Distribuição de enxofre entre os principais sulfetos .........................................92

4.2.7 Tamanho de grãos de ouro e de clusters de sulfetos ........................................93

4.2.8 Associações dos grãos de ouro por perímetro de contato .....................................95

4.2.9 Formas de ocorrência e estimativa da composição de ouro ................................97

5 DISCUSSÃO DOS RESULTADOS ........................................................... 101

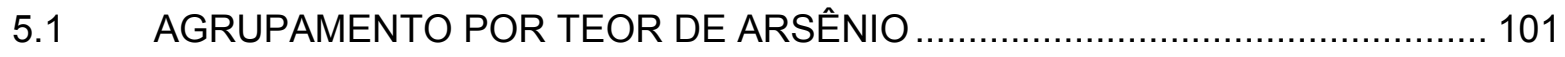

5.2 CLASSIFICAÇÃO POR PENEIRAMENTO EM 0,020 MM ................................ 102

5.2.1 Análise granulométrica e separações minerais ................................................102

5.3 SEPARAÇÕES MINERAIS POR LÍQUIDOS DENSOS ................................ 104 


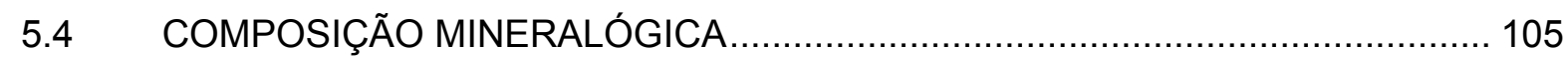

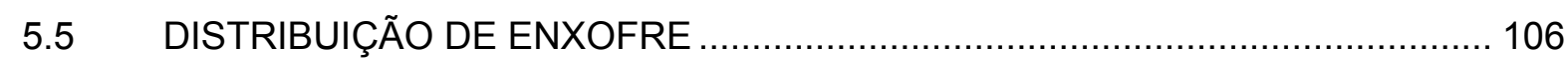

5.6 TAMANHOS DOS GRÃOS DE OURO E DE SULFETOS ................................. 107

5.7 ASSOCIAÇÕES MINERAIS DE OURO E SULFETOS ................................... 109

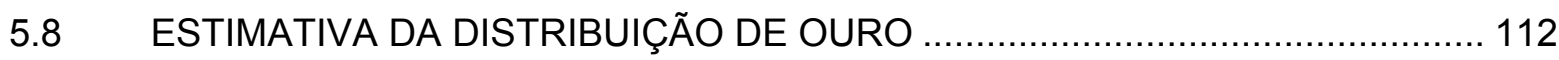

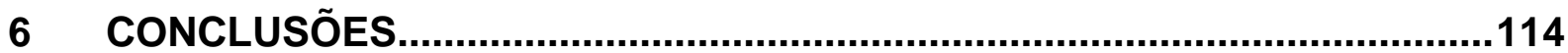

6.1 SUGESTÕES DE TRABALHOS COMPLEMENTARES ................................. 117

REFERÊNCIAS BIBLIOGRÁFICAS ................................................................119

APÊNCIDE 1 - Proveniência e composição química das amostras ........................128

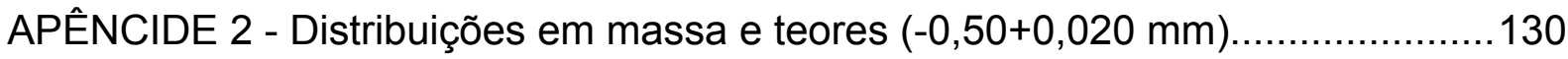

APÊNCIDE 3 - Separações em líquido denso $\left(3,30 \mathrm{~g} / \mathrm{cm}^{3} ;-0,50+0,020 \mathrm{~mm}\right) \ldots \ldots . .132$ APÊNCIDE 4 - Composições mineralógicas das amostras estudadas (fração -

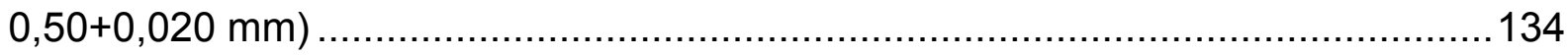

APÊNCIDE 5 - Estimativa da distribuição de enxofre estudadas (fração -0,50+0,020

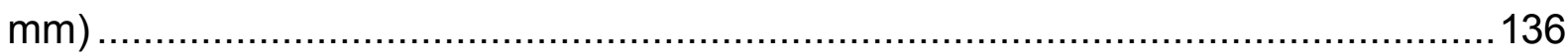

APÊNCIDE 6 - Granulação média dos sulfetos (fração -0,50+0,020 mm) .............138

APÊNCIDE 7 - Caracterização dos grãos de ouro (fração -0,50+0,020 mm) .........140

APÊNCIDE 8 - Características dos grãos de ouro (fração -0,50+0,020 mm) .........142

APÊNCIDE 9 - Associações dos grãos de ouro por perímetro de contato (2D) .....144 APÊNCIDE 10 - Imagens de elétrons retroespalhados - Grãos de ouro acessível.146 APÊNCIDE 11 - Imagens de elétrons retroespalhados - Grãos de ouro não

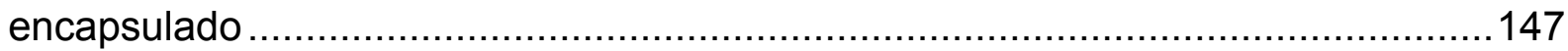

APÊNCIDE 12 - Imagens de elétrons retroespalhados - Grãos de ouro inclusos ...148 


\section{INTRODUÇÃO}

A constante busca por um empreendimento de mineração cada vez mais eficiente, com uma produção de baixo custo e aliado a um ganho financeiro maximizado é o objetivo da indústria, não só mineral, mas de todo o setor produtivo.

Em uma unidade de beneficiamento de minério de ouro, as instalações de processamento respondem por grande parte do custo geral no empreendimento mineiro. Um estudo mineralógico, em referência ao desempenho do minério na usina de processamento, permite agregar conhecimento gerando alternativas de otimização e consequente redução dos custos no processamento.

A mina Morro do Ouro, localizada no município de Paracatu, Minas Gerais, responde por 29\% da produção nacional de ouro (IBRAM, 2012). Em 2013 foram produzidas 500.380 onças troy de ouro e em $2014,521.026$ onças representando um aumento de $4,1 \%$ na produção ${ }^{1}$.

Embora o empreendimento esteja em atividade desde os anos 90, o conhecimento em relação as características tecnológicas do minério ainda são escassas, principalmente quanto a precisão dos dados.

No presente trabalho foram analisadas as características tecnológicas de amostras que compõe três corpos de minério definidos pela empresa em relação ao seu conteúdo de arsênio, enxofre e ouro. As amostras foram analisadas quanto a sua composição mineralógica, associações entre os sulfetos e ouro e características dos grãos de ouro e partículas de sulfetos. Foram analisadas um conjunto de oitenta e oito amostras pontuais provenientes de sondagens e frentes de lavra (representatividade de 1 a $3 \mathrm{~m}$ ). Para a determinação de composição mineralógica, identificação dos grãos de ouro, suas características e associações com sulfetos foi empregada análise de imagens automatizada por meio do sistema MLA (Mineral Liberation Analyser).

\footnotetext{
${ }^{1}$ http://2014annualreport.kinross.com/pdf/annual-report-2014.pdf
} 


\subsection{OBJETIVO}

O objetivo do trabalho é estabelecer as associações mineralógicas e características dos sulfetos e dos grãos de ouro do depósito Morro do Ouro.

\subsection{RELEVÂNCIA DA PESQUISA}

As recentes mudanças no setor mineral implicam em um novo ambiente de trabalho de intensa competição não só no Brasil, como no exterior. As tendências de internacionalização das operações bem como o fluxo de investimento fazem com que as empresas adotem técnicas de avaliação e processamento dos minérios visando à redução do risco e maximização do investimento.

Dentro dessa perspectiva, aliado ao sistema teórico e prático, a possibilidade de geração de conhecimento através do estudo das características das associações mineralógicas do ouro e dos sulfetos, pode propiciar melhorias no planejamento de lavra e no desempenho no processamento do minério na usina, o que significa melhor aproveitamento dos recursos minerais e maior retorno financeiro.

Outro fator relevante é a contribuição do trabalho em relação ao estudo da caracterização tecnológica para minérios auríferos. Encontram-se escassos trabalhos científicos acerca do tema abordado na dissertação que vão desde a fundamentação teórica até a relação do ouro com o arsênio.

\subsection{ESTRUTURA DA DISSERTAÇÃO}

Esta dissertação encontra-se organizada em sete capítulos:

Capítulo 1 - Introdução: O capítulo situa a dissertação no contexto do tema escolhido apresentando ao leitor o objetivo e relevância da pesquisa.

Capítulo 2 - Revisão bibliográfica: Apresenta o contexto atual da caracterização tecnológica e a suas aplicações no processamento mineral. São descritas nesse capítulo também as principais técnicas de caracterização tecnológica e o contexto geológico da área de estudo.

Capítulo 3 - Materiais e métodos: Descreve e detalha o procedimento experimental empregado e os materiais estudados. 
Capítulo 4 - Resultados: Apresenta os principais resultados obtidos a partir da metodologia aplicada para as amostras estudadas.

Capítulo 5 - Discussão dos Resultados: Discute os resultados obtidos, correlacionando os principais aspectos e suas diferenças.

Capítulo 6 - Conclusões: O capítulo retoma os principais aspectos discutidos e os resultados mais significativos da dissertação. $O$ último subitem sugere estudos adicionais acerca do tema.

Referências bibliográficas: Trabalhos utilizados para discorrer e analisar acerca do tema abordado.

Nas figuras, tabelas e quadros produzidos pelo próprio autor, onde não há referência na parte inferior, entende-se como fonte: do autor. 


\section{REVISÃo BIBLIOGRÁFICA}

\subsection{CONSIDERAÇÕES SOBRE OS DEPÓSITOS DE OURO}

O ouro possui alta resistência ao ataque químico, alta condutividade elétrica, ductilidade e alta densidade $\left(19,3 \mathrm{~g} / \mathrm{cm}^{3}\right)$. É um metal raro e o seu teor médio na crosta terrestre é de $3 \mathrm{ppb}$ e em jazidas é 10.000 vezes maior, ou seja, cerca de 0,3 ppm (O'CONNOR et al., 1994).

O ouro tem sido um bem mineral mais almejado por, pelo menos, 7.000 anos. No Egito antigo, a região do deserto oriental enquadrado no embasamento pré-cambriano Arabian-Nubian abasteceu o império com cerca de 250 minas com a produção durante as diferentes dinastias egípcias (KLEMM et al., 2001).

Em geral, a classificação dos depósitos minerais promove um cenário essencial para delimitação das estratégias de pesquisa, avaliação de prospectos e de recursos em uma determinada área (ROBERT et al., 1997).

Os depósitos de ouro sempre detiveram um grande trabalho e esforço na sua classificação devido à sua grande diversidade genética. Além disso, as classificações são levadas em consideração sob diferentes aspectos, seja pela sua gênese, geoquímica, potencial econômico ou pelo contexto geotectônico, o que amplia cada vez mais quando essas variáveis são relacionadas e integradas.

Na sua classificação, também pode ocorrer a superposição de eventos com dois ou mais sistemas hidrotermais constituindo depósitos híbridos ou, ainda, a superposição de ambientes geotectônicos distintos, tal como arcos continentais superpostos em terrenos vulcânicos, acarretando dificuldades na determinação das feições geológicas relativas a cada ambiente (SILLITOE, 1994).

Desde o Arqueano, os depósitos de ouro têm sido formados em uma grande variedade de ambientes. Essa variabilidade implica em diferentes agentes de transporte e concentração como, por exemplo, interações magmáticas, hidrotermais (rocha-fluído) e processos sedimentares (GROVES et al., 2005; BIERLEIN et al., 2006). Exemplo importante de formação aurífera no Arqueano são os depósitos orogênicos hospedados em greenstone belts (GSB), os quais hospedam mineralizações de ouro 
de classe mundial, com mais de 500 toneladas de ouro. No Brasil, por exemplo, temse operações no greenstone belts de Crixás (JOST et al., 1991), pela empresa AngloGold Ashanti (Mineração Serra Grande) e Rio Itapicuru (MELLO et al., 1996), com a Brio Gold (Mineração Fazenda Brasileiro).

Segundo FRIMMEL (2008), um modo de classificar os depósitos auríferos é com base no seu ambiente geotectônico e geológico de formação. A Figura 2.1, sumariza os principais ambientes geotectônicos e o Quadro 2.1 apresenta os principais exemplos proeminentes para cada tipo.

Figura 2.1 - Esquema dos ambientes de formação dos depósitos de ouro

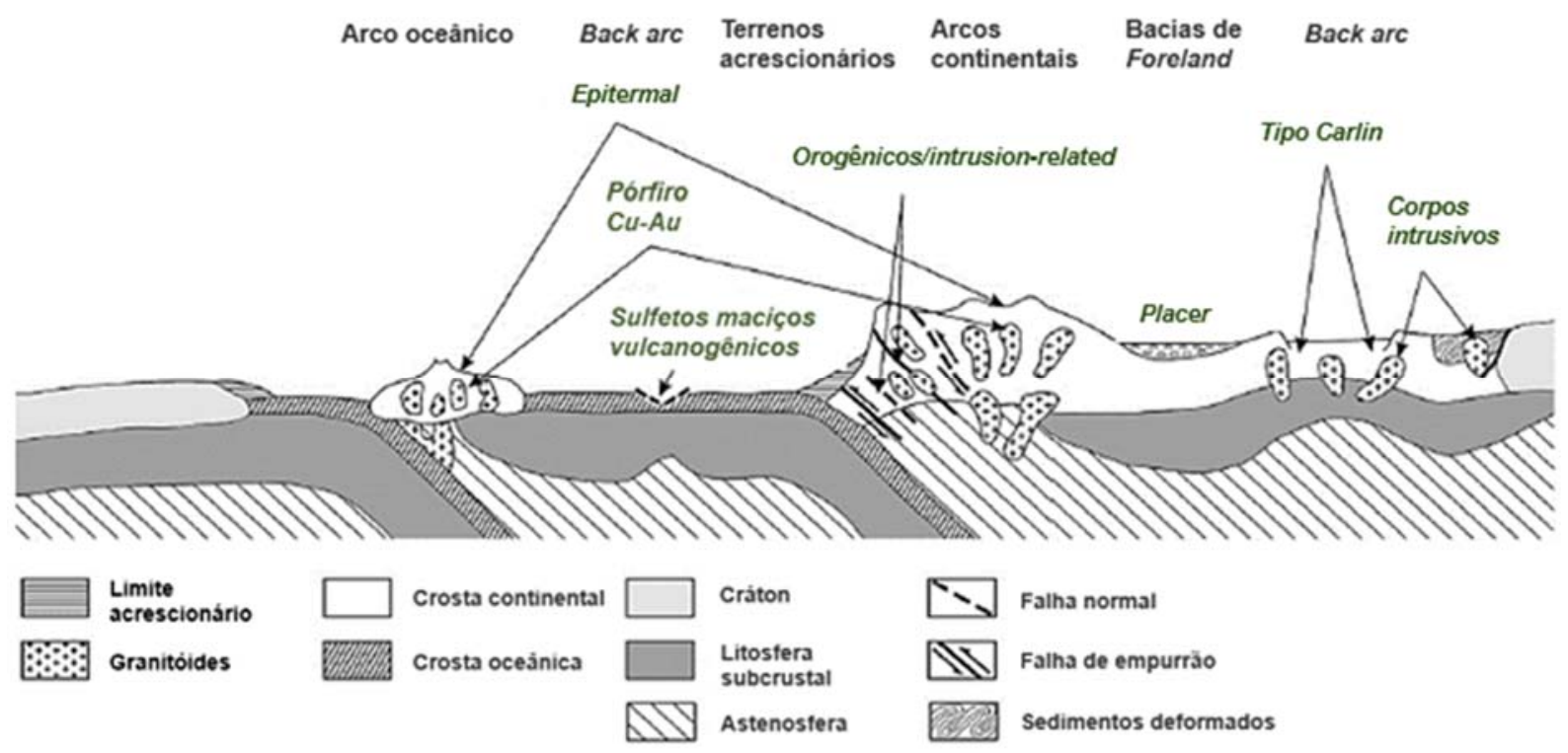

Esquema ilustrando os ambientes litosféricos em grande escala da formação dos principais tipos de depósitos de ouro. Modificado de (GROVES et al., 2005).

Os depósitos de paleoplacers consistem em camadas estratiformes associadas a conglomerados e arenitos com enriquecimento em finas camadas carbonáticas e associados a corpos intrusivos juntamente com corpos orogênicos. Exemplos nesse contexto incluem os depósitos em conglomerados da Bacia Sul Africana de Witwatesrand e de Jacobina (MASCARENHAS et al., 1998). Nos depósitos de Witwatesrand ocorrem anomalias de urânio-ouro desenvolvidas em quatro fases principais, sendo a primeira com a concentração de minerais pesados controlada por processos de sedimentação detríticas que resultou na formação do delta e em horizontes de ouro. A segunda fase provocou a maturação da matéria orgânica 
existentes nas rochas sedimentares o que ocasionou nódulos de betume que enveloparam as maiores concentrações de uraninita. A fase seguinte foi responsável pela fase de maturação e circulação de fluidos ricos em hidrocarbonetos seguido pela precipitação de sulfetos e ouro antigênicos (ROBB et al., 1995). Esse depósito atingiu um pico de produção de 1.000 toneladas de ouro em 1970, sendo notadamente a maior bacia produtora de ouro em escala global, correspondendo por cerca de $40 \%$ de todo ouro já produzido (HARTNADY, 2009).

Quadro 2.1 - Principais depósitos de ouro de escala mundial

\begin{tabular}{|c|c|c|c|c|}
\hline Depósito/província & País & Feição geotectônica & $A u(t)$ & Teor (ppm) \\
\hline \multicolumn{5}{|l|}{ Paleoplacers } \\
\hline Witwatesrand & África do Sul & Cráton do Kaapvaal & 96,703 & $2.0-10$ \\
\hline Berelekh & Rússia & Plataforma da Sibéria & 2,179 & 12.0 \\
\hline Tarkwa & Gana & Cráton africano & 2,158 & 1.5 \\
\hline \multicolumn{5}{|c|}{ Orogênicos e intrusivos } \\
\hline Muruntau $\left(1^{\circ}\right)$ & Uzbequistão & Orogenia Tien Shan & 6,137 & 3.5 \\
\hline Ashanti & Gana & Cráton africano & 3,169 & $2.0-7.0$ \\
\hline Golden Mile & Austrália & Cráton do Yilgarn & 2,079 & 2.0 \\
\hline Telfer & Austrália & Orogenia Paterson & 1,527 & 1.5 \\
\hline Homestake & Canadá & Orogenia TransHudson & 1,237 & 8.3 \\
\hline Olimpiada $\left(8^{\circ}\right)$ & Rússia & Cráton da Sibéria & 1,030 & 3,5 \\
\hline Sukhoi Log & Rússia & Cráton da Sibéria & 1,361 & 2.5 \\
\hline \multicolumn{5}{|c|}{ Pórfiros de Cu-Au em arcos vulcânicos } \\
\hline Grasberg $\left(2^{\circ}\right)$ & Indonésia & Arco de llha & 6,817 & 0.9 \\
\hline Kalmakyrsk & Uzbequistão & Arco continental & 1,299 & 0.6 \\
\hline Boddington $\left(10^{\circ}\right)$ & Austrália & Cráton do Yilgarn & 1,277 & 0.9 \\
\hline Cananea & México & Arco continental & 1,269 & 0.3 \\
\hline Ok Tedi & Papua Nova Guiné & Arco de Ilha & 1,128 & 1.0 \\
\hline Porgera & Papua Nova Guiné & Arco de llha & 1,113 & 3.5 \\
\hline Bingham & Estados Unidos & Arco continental & 1.001 & 0.3 \\
\hline \multicolumn{5}{|l|}{ Epitermal } \\
\hline Pueblo Viejo ( $\left.3^{\circ}\right)$ & República Dominicana & Arco de llha & 12,5 & 1,4 \\
\hline Ladolam (Lihir) & Papua Nova Guiné & Arco de llha & 2,074 & 3.2 \\
\hline Veladero $\left(9^{\circ}\right)$ & Argentina & Arco continental & 21,49 & 0,6 \\
\hline Yanacocha $\left(4^{\circ}\right)$ & Peru & Arco continental & 1,956 & 1.2 \\
\hline \multicolumn{5}{|l|}{ Tipo Carlin } \\
\hline Newmont & Estados Unidos & Back arco & 2,788 & 1.7 \\
\hline Betze Post & Estados Unidos & Back arco & 1,702 & 4.1 \\
\hline Carlin Trend $\left(5^{\circ}\right)$ & Estados Unidos & Back arco & 1,278 & 1.6 \\
\hline Cortez $\left(6^{\circ}\right)$ & Estados Unidos & Back arco & 1,258 & 1.4 \\
\hline Goldstrike $\left(7^{\circ}\right)$ & Estados Unidos & Back arco & 1,957 & 0.3 \\
\hline
\end{tabular}




\begin{tabular}{lllll}
\hline Depósito/província & País & Feição geotectônica & Au (t) & Teor (ppm) \\
\hline Depósitos IOCG & & & & \\
Olympic Dam & Austrália & Cráton Gawler & 1,995 & 0.6 \\
Salobo & Brasil & Província dos Carajás & 1,000 & 0.4 \\
Ernest Henry & Austrália & Orogenia Barramundi & 0,200 & 0.5 \\
Vulcânicos - VMS & & Back arco & 1,611 & \\
Horne & Canadá & Abitibi Greenstone Belt & & 6,1 \\
Mount Morgan & Austrália & Arco de ilha Calliope & 0,300 & 4,8 \\
Escarnitos & & Arcos vulcânicos & 1,467 & \\
Magmáticos & & Terrenos ultramáficos & 1,333 & \\
Sin-sedimentares & & Margem passiva & 1,070 & \\
\hline
\end{tabular}

Principais classes de depósitos de ouro, acima de $1000 \mathrm{t}$ de ouro. Adaptado de FRIMMEL (2008). Entre parênteses, a classificação quanto a produção de ouro em 2014 [http://www.mining.com/the-worldstop-10-gold-mines/].

Os depósitos em zonas extensionais ocorrem preferencialmente em ambiente de retroarco (back arc) e são tipicamente corpos mineralizados hospedados em rochas sedimentares clásticas em greenstone belts. Nesse contexto, se inserem também os depósitos VMS. A mineralização aurífera ocorre principalmente na forma disseminada, associada aos sulfetos como pirita, marcassita, arsenopirita, entre outros. O principal modelo genético para esse tipo de depósito é o tipo Carlin localizado em Nevada, EUA e está relacionado ao enriquecimento de ouro, antimônio, mercúrio, tálio e bário transportados por fluídos metamórficos e magmáticos (CLINE et al., 2005).

Os depósitos denominados do tipo Carlin são epigenéticos hospedados em rochas sedimentares de baixo grau (siltitos e carbonatos). Os sulfetos ocorrem disseminados e em corpos alongados com controle estrutural, estratigráfico e associados com sistemas de corpos intrusivos distais (CLINE et al., 2005). Este tipo de depósito corresponde a $9 \%$ de todo ouro produzido mundialmente e são reconhecidos no nordeste do estado americano de Nevada e noroeste de Utah sendo os mais importantes produtores de ouro no oeste dos Estados Unidos.

Os depósitos orogênicos são associados a zonas orogênicas, ou seja, zonas de fechamento orogenético e que não necessariamente se aplicam ao Arqueano ou a terrenos GSB. Esse termo foi proposto por GROVES et al., (1998), em substituição do termo depósito de ouro mesotermal. O mesmo autor sugere a denominação devido ao fato dos depósitos serem formados durante os processos de deformação compressional e transpressional em margens de placas convergentes em ambientes 
de orogenia acrescionária ou colisional. Neste tipo de depósito, as associações mais frequentes na fácies xisto verde incluem carbonato - sulfeto \pm mica \pm clorita que resultam na interação de fluidos de baixa salinidade e ricos em $\mathrm{CO}_{2}$. Exemplos clássico de depósitos de ouro orogênicos são os depósitos no Quadrilátero Ferrífero, Grupo Nova Lima (LOBATO et al., 2001), base do Grupo Quebra Osso (SCHORSCHER et al., 1978).

Os depósitos $\mathrm{IOCG}^{2}$ incluem mineralização principalmente de cobre, por vezes associado a ouro, com controle estrutural proeminente em veios hidrotermais, brechas e abundância de óxidos de ferro com baixo teor de titânio (magnetita e/ou hematita) e assinatura geoquímica distinta (elementos terras raras, $\mathrm{Co}, \mathrm{Ag}, \pm U, P$ ), entre outras (WILLIAMS et al., 2005). Os depósitos polimetálicos da Província de Carajás (Igarapé Bahia, Alemão, Cristalino, Gameleira, Salobo e Sossego) são relacionadas a esse tipo genético. O depósito de Sossego compreende em duas grandes jazidas com estilos distintos de alteração hidrotermal com diferentes rochas hospedeiras e intensidade de interação rocha-fluído distintas (MONTEIRO et al., 2008).

Os depósitos do tipo $\mathrm{VMS}^{3}$ são as maiores fontes de $\mathrm{Zn}, \mathrm{Cu}, \mathrm{Pb}, \mathrm{Ag}$ e $\mathrm{Au}$, tendo como subprodutos $\mathrm{Co}, \mathrm{Sn}, \mathrm{Se}, \mathrm{Mn}, \mathrm{Cd}$, In, Bi, Te, Ga e Ge. Eles ocorrem tipicamente como lentes de sulfetos polimetálicos que se formam próximo do assoalho oceânico em ambientes de vulcanismo submarino por meio de focos de descargas de fluidos hidrotermais ricos em metais. Embora os depósitos do tipo SedEx ${ }^{4}$ sejam classificados como exalativos, ele não são considerados um subtipo do deposito VMS por não ter associação com vulcanismo ativo (GALLEY et al., 2007).

Os depósitos de ouro pórfiro são uma variante dos depósitos de cobre pórfiro que tem como característica teores de ouro acima de 1,5 ppm. No geral, os depósitos de cobre pórfiro ricos em ouro não diferem dos demais depósitos porfiríticos de Cu-Mo, entretanto, os primeiros apresentam uma maior quantidade de magnetita hidrotermal em relação aos demais. Os depósitos de Cu-Au estão associados com arcos de ilhas, enquanto os depósitos de Cu-Mo pórfiro estão associados com arcos continentais.

\footnotetext{
2 IOCG: iron oxide copper-gold.

${ }^{3}$ VMS: sulfetos maciços vulcanogênicos

${ }^{4}$ SedEx: depósitos sedimentares exalativos
} 
São exemplos nesse contexto, os depósitos localizados em arcos de ilhas no sudoeste do Pacifico, tais como Grasberg e Batu Hijau na Indonésia; Panguna e Ok Tedi em Papua Nova Guiné (SUN et al., 2015).

Depósitos epitermais nas quais se encontram mineralizações de ouro são aqueles que são formados em profundidade de até $1 \mathrm{~km}$ da superfície através de sistemas hidrotermais de baixas temperaturas (abaixo de $300^{\circ} \mathrm{C}$ ) e são associados a ambientes vulcânicos. Os depósitos formados nesse tipo de ambiente podem ter formas e tamanhos muito variados mas geralmente estão relacionados a estruturas de amplitude regional. Podem ocorrer na forma de veios, stockworks ou ainda disseminados.

A característica principal dos depósitos epitermais é a alteração hidrotermal produzida nas rochas encaixantes, que podem fornecer importantes informações na caracterização dos depósitos. (HEDENQUIST et al., 1996). A classificação mais utilizada foi proposta por HENLEY (1991). Este autor divide os depósitos epitermais em dois tipos: alta sulfetação (ou ácidosulfato) e baixa sulfetação (ou adularia-sericita) baseados principalmente no tipo de alteração e mineralogia do depósito.

\subsubsection{Modelo metalogenético do depósito do Morro do Ouro}

O depósito Morro do Ouro é um depósito disseminado em filitos deformado e metamorfizado em fáceis xisto-verde de baixo grau (Formação Paracatu, Membro Morro do Ouro), no Brasiliano (850-500 Ma), com dobras isoclinais, recumbentes e zonas de cisalhamento de caráter dúctil-rúptil (SCHOBBENHAUS et al., 2001).

Para OLIVER et al., (2015), o depósito de ouro de baixo teor está associado a um intenso cisalhamento e cavalgamento ocorrido no ciclo Brasiliano. Lentes maciças e lâminas de quartzo-sulfetos-carbonatos alterada, ocorrem associados a mineralização de ouro formado nos estágios iniciais da história de deformação. Essas lentes e veios foram transformadas em boudins, durante o avanço progressivo das zonas de cisalhamento (shear strain). Perfis geoquímicos realizados em amostras de minério de ouro permitiu o reconhecimento de um protólito homogêneo em relação aos elementos $\mathrm{Ti}, \mathrm{Al}, \mathrm{Zr}$, V, e terras raras, incluindo a lapa com atributos similares às do minério. Isótopos de oxigênio, hidrogênio e enxofre não revelaram uma fonte externa 
distinta de fluido, que ao contrário, revela um equilíbrio fluido-rocha com o filito durante o metamorfismo regional (fáceis xisto-verde).

Trabalhos realizados na década de 90 já sinalizaram para um contexto orogênico, definindo a mineralização de ouro como sendo hospedada em filitos grafitosos associado geneticamente em zonas de cisalhamento nesse contexto (FREITAS SILVA et al., 1996; MYASHITA, 2005 ).

Para MYASHITA (2005), as observações de campo sugerem mineralização ou remobilização sin-tectônica da assembleia sulfetada, pois são frequentes as concentrações de sulfetos em sombras de pressão e zonas de distensão. Desta forma, a indicação da gênese em depósito do tipo Carlin tornam-se dificultadas, já que as observações de campo não permitem inferir a respeito de remobilizações e zonas de sulfetos sobrepostas após o evento tectônico, além da não constatação de granitogênese concomitante à formação dos litotipos do Grupo Canastra.

\subsection{PANORAMA DO OURO}

Segundo relatório da World Gold Council' , no primeiro trimestre de 2015, o consumo global de ouro foi de $55 \%$ para a indústria de joias, $10 \%$ para tecnologia e $35 \%$ para ativos financeiros.

Embora o Brasil apresente ampla distribuição territorial, cerca de $90 \%$ da produção aurífera interna é proveniente de apenas cinco estados: Minas Gerais (51,6\%), Goiás $(18,8 \%)$, Bahia $(11,7 \%)$, Pará $(10,1 \%)$ e Mato Grosso $(7,8 \%)$. Por outro lado, as maiores reservas de ouro estão no Estado da Bahia com 1.291.355 kg de ouro contido lavrável, seguido por Minas Gerais, com 581.814 kg (DNPM, 2010). A Tabela 2.1 apresenta as principais reservas minerais de ouro por unidade de federação.

\footnotetext{
${ }^{5}$ World Gold Council - http://www.gold.org/supply-and-demand/gold-demand-trends
} 
Tabela 2.1 - Reservas minerais de ouro por unidade de federação

\begin{tabular}{lrrrr}
\hline Unidades da federação & \multicolumn{3}{c}{ Reservas (kg) } & Lavrável (kg) \\
& Medida & Indicada & Inferida & - \\
\hline Alagoas & 4.040 & 10.176 & 27.040 \\
Amapá & 13.581 & 27.910 & 34.550 & 33.390 \\
Amazonas & 4.967 & 2,152 & & 654 \\
Bahia & 1.342 .755 & 75.637 & 134.600 & 1.291 .355 \\
Goiás & 48.583 & 85.771 & 29.965 & 71.050 \\
Maranhão & 441.125 & 155.638 & 10.793 & 22.675 \\
Mato Grosso & 183.693 & 114.238 & 179.495 & 73.885 \\
Minas Gerais & 789.916 & 464.707 & 308.046 & 581.814 \\
Pará & 465.487 & 704.64 & 1.062 .543 & 488.104 \\
Paraiba & 792 & 404 & 54 & \\
Paraná & 7.197 & 8.695 & 4.187 & 14.010 \\
Rio Grande do Norte & 1.418 & 220 & & 547 \\
Rio Grande do Sul & 7.97 & 1.557 & 2.292 & 3.314 \\
Rondônia & & 3.332 & 8.189 & 3.332 \\
Santa Catarina & 1.590 & 1.246 & 961 & \\
São Paulo & 1.620 & 2.104 & 468 & 1.627 \\
Tocantins & 2.092 & 3.154 & 6.475 & 2.092 \\
\hline
\end{tabular}

Fonte: adaptado de DNPM (2010).

No ano de 2012, a exportação de ouro no Brasil representou $6,1 \%$ do setor mineral que teve como predomínio o minério de ferro, com $80,1 \%$ do total (IBRAM, 2012) ${ }^{6}$. No ano de 2015, a taxa de arrecadação fiscal (CFEM) representou um aumento de 21,1\% (70,3 milhões de reais) em relação ao ano anterior (55,4 milhões de reais). Em relação a todo o bem mineral explorado, o ouro representou, em $2015,4,6 \%$ de toda a arrecadação e em 2014, 3,2\%. Esse aumento expressivo se deve principalmente a caída da arrecadação para o minério de ferro, que de 2014 para 2015 foi de $36,3 \%$. (2014: 1,1 bilhões reais e 2015: 790 milhões de reais) ${ }^{7}$.

A Figura 2.2 apresenta a evolução da produção de ouro para a indústria e lavra garimpeira. Os dados mostram que a produção aurífera em escala industrial vem aumentando, enquanto a produção proveniente dos garimpos vem diminuindo, refletindo uma inversão na situação comparativamente com os anos de 1980 e 1990.

\footnotetext{
${ }^{6}$ http://www.ibram.org.br/sites/1300/1382/00003797.pdf

${ }^{7}$ https://sistemas.dnpm.gov.br/arrecadacao/extra/Relatorios/arrecadacao_cfem_substancia.aspx
} 
Figura 2.2 - Produção de ouro em escala industrial e garimpeira (1988 - 2014)

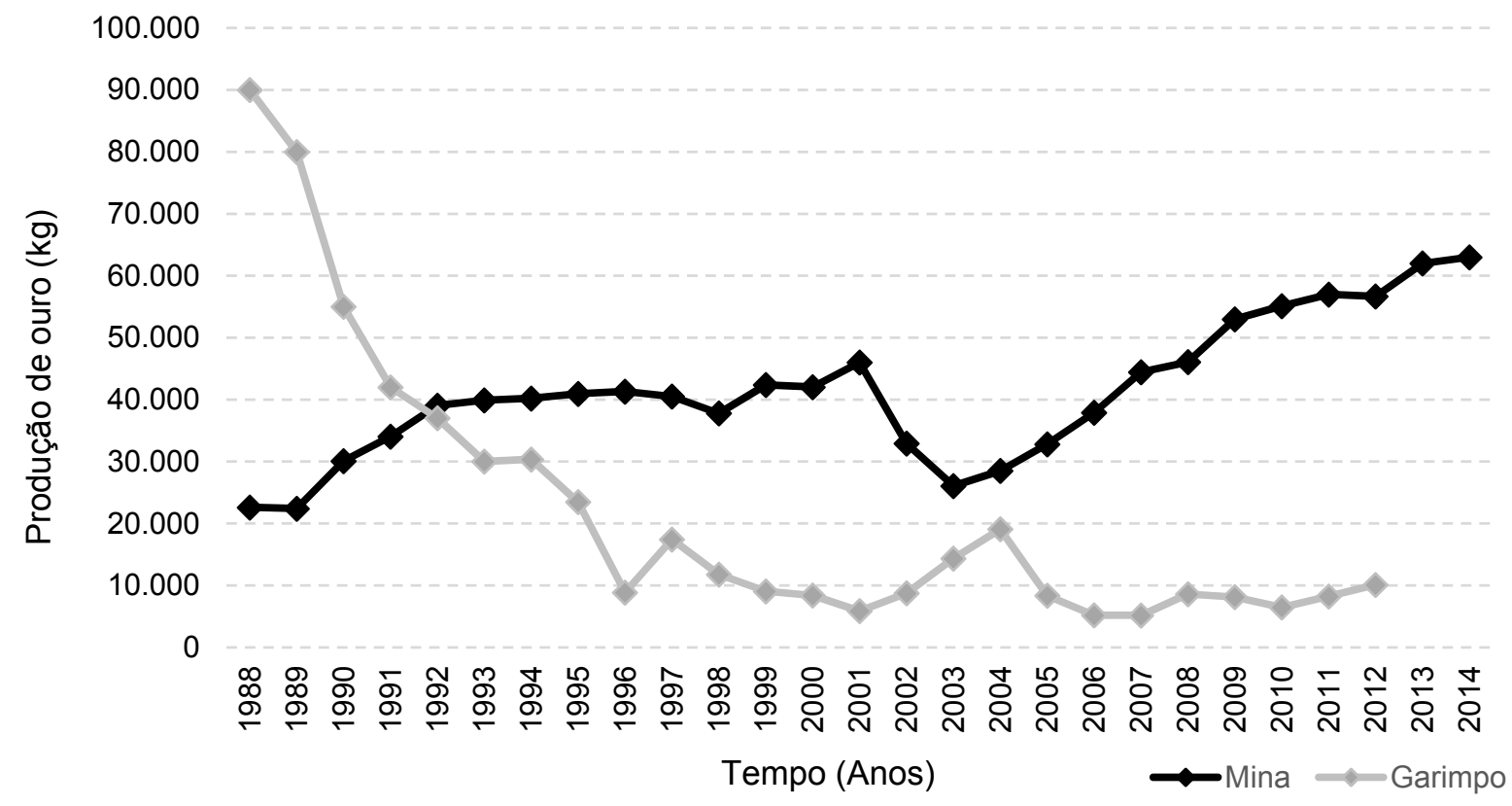

Fonte: DNPM ${ }^{8}$

A produção oriunda da mineração oscilou em torno de 40 mil toneladas na década de 1990. O declínio da atividade garimpeira teve início no final da década de 1980 em decorrência do projeto de lei (Lei 7.805 de 18 de julho de $1989^{9}$ ) que regulamenta a atividade garimpeira sob permissão concedida pelo DNPM à pessoa física ou coorporativa de garimpeiros autorizada a funcionar como empresa. O órgão exige ainda a obrigatoriedade da licença ambiental prévia, que deveria ser concedida pelo órgão ambiental competente sendo considerado punível com prisão a realização de trabalhos de extração de substâncias minerais, sem a competente permissão, concessão ou licença. Um outro projeto de lei (Lei no. 8.176 de 8 de fevereiro de $1991^{10}$ ) veio a agravar a situação dos garimpeiros levando-os à clandestinidade ao considerar como crime, na modalidade de usurpação, a produção de bens ou a exploração de matéria-prima pertencentes à União, sem autorização legal ou em desacordo com as obrigações impostas pelo título autorizativo.

\footnotetext{
${ }^{8}$ http://www.dnpm.gov.br/assuntos/economia-mineral

${ }^{9}$ http://Www.planalto.gov.br/ccivil_03/LEIS/L7805.htm

${ }^{10}$ http://www.planalto.gov.br/CCivil_03/leis/L8176.htm
} 
No Brasil, 10 empresas respondem por $88 \%$ da produção de ouro; as principais empresas produtoras de ouro do Brasil em 2012, segundo o Instituto Brasileiro de Mineração (IBRAM, 2012) estão relacionadas na Tabela 2.2.

Tabela 2.2 - Principais empresas produtoras de ouro em 2012, incluindo garimpo

\begin{tabular}{lcc}
\hline Empresa & UF & Participação (\%) \\
\hline Kinross Brasil Mineração S.A. & MG & 29,0 \\
AngloGold Ashanti Brasil Mineração Ltda. & MG/GO & 22,0 \\
Yamana Gold & GO/BA & 17,0 \\
Jaguar Mining & MG & 7,0 \\
Outras & & 13,0 \\
Garimpos & & 12,0 \\
\hline
\end{tabular}

Fonte: adaptado de IBRAM (2012).

O Brasil é o décimo primeiro maior produtor de ouro, com produção de 70 toneladas em 2014. A China é a maior produtora, com 450 toneladas $(15,7 \%$ da produção mundial), seguida pela Austrália com $10,6 \%$, pela Rússia ( $8,5 \%$ da produção mundial) e EUA (7,3\%) (USGS, 2015).

\subsubsection{Evolução dos preços no mercado nacional e internacional}

O ouro durante um longo período serviu como garantia de valor, o que, em períodos de grande instabilidade no setor financeiro, tem conduzido muitos investidores a mantê-lo como valor de refúgio, ou seja, o ativo (ouro) mantém seu valor em períodos conturbados ou de condições adversas de mercado (BAUR et al., 2010). O grande aumento do preço do ouro a partir de 2005 deve-se essencialmente à sua procura para a indústria da ourivesaria, de tecnologia e pelo fato do mercado ter sido impulsionado por investidores que procuram um meio seguro de investimento. Para estes investidores, a aquisição de ouro é vista como uma garantia numa situação de crise.

Ao longo da década de 1970, houve um aumento significativo nos preços dos metais, tendo o ouro vivido, no período, um crescimento muito expressivo (Figura 2.3). Essa subida no preço do metal foi ocasionada pela suspensão da conversibilidade entre o dólar e o ouro tomada pelos Estados Unidos o que, a partir de então, gerou incertezas quanto ao valor da moeda americana ao longo do tempo, mas não o ouro como 
referência. Dessa forma, criou-se uma quebra histórica estável entre os dois ativos, favorecendo à especulação do ouro. Em pouco mais de 5 anos, o ouro passou de 35 US\$/oz ${ }^{11}$ em 1970 para 161 US\$/oz em 1975. Para Araújo (2013), as flutuações do preço do ouro podem estar ligadas a seis fatores: a evolução do dólar, rendimento de outros ativos, a demanda (oferta e procura) de ouro, as reservas internacionais de ouro, a inflação e as influências macroeconômicas.

O aumento dos preços do ouro em 1980 foi ocasionado principalmente pela instabilidade da economia americana, o aumento no preço do petróleo, a intervenção da antiga União Soviética no Afeganistão e a revolução iraniana. Outro aumento significativo nos preços do ouro foi a partir de 2001 com o aumento forte da economia chinesa e pela instabilidade dos mercados globais.

Figura 2.3 - Cotação média anual do preço do ouro (1968 - 2014)

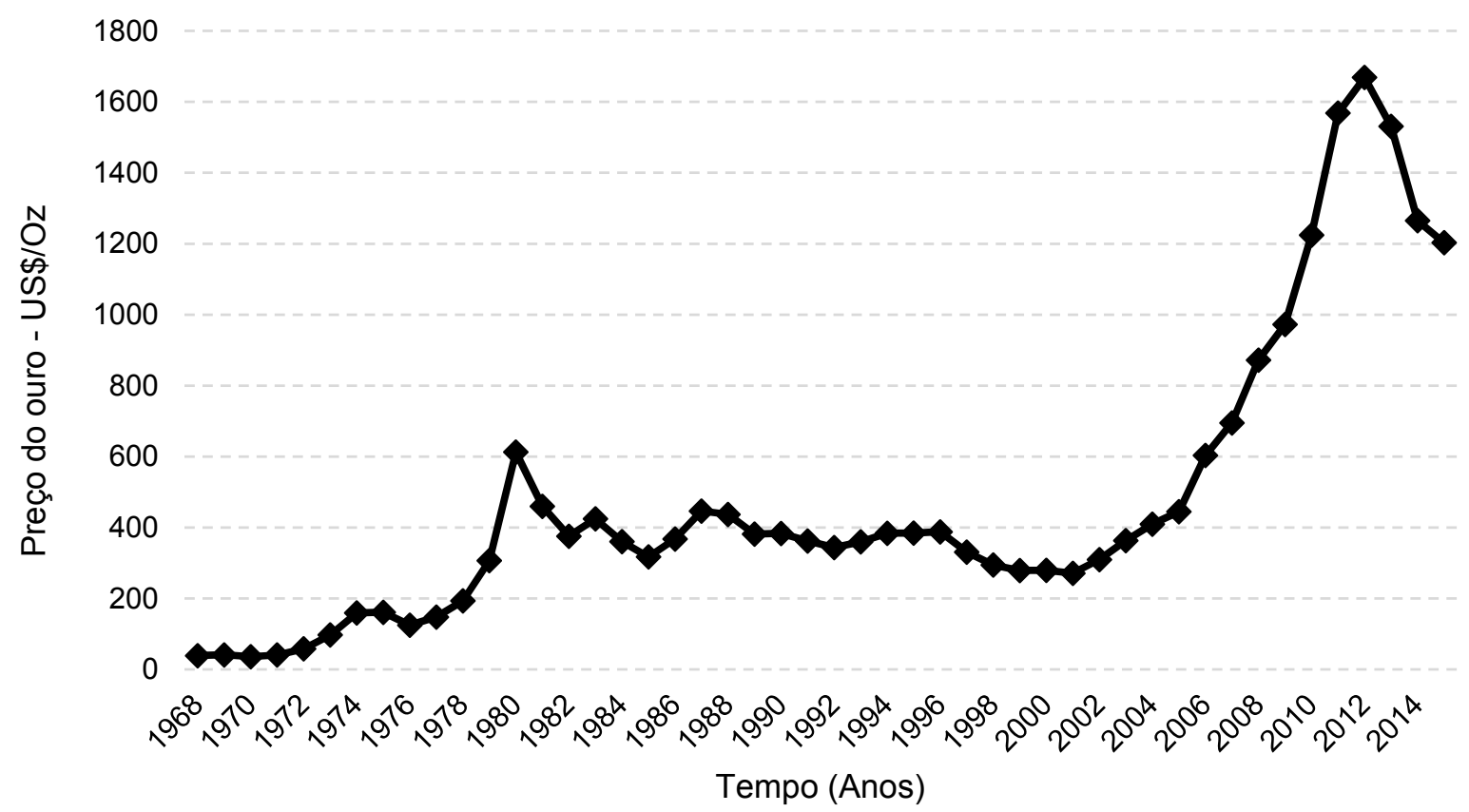

Fonte: London Bullion Market Association - LBMA ${ }^{12}$

11 US\$/oz: Preço da onça por dólar sendo 1 onça troy equivalente a 31,103 gramas

${ }^{12}$ http://www.lbma.org.uk/pricing-and-statistics 


\subsection{MINÉRIOS AURÍFEROS}

\subsubsection{Ocorrência de ouro}

Os minérios auríferos são comumente classificados no processo metalúrgico em duas categorias principais: "free-milling" e minérios refratários. Minérios de ouro do tipo "free-milling" são definidos como aqueles onde mais $90 \%$ de ouro pode ser recuperado por lixiviação via cianetação convencional. Minérios refratários são aqueles que tem baixa recuperação de ouro ou recuperação aceitável com a utilização significativa de reagentes ou processos mais complexos de tratamento (ustulação, etc.) (ZHOU et al., 2004).

Com base nas características mineralógicas e técnicas de processamento mineral, os minérios auríferos podem ser agrupados em 11 tipos (ZHOU et al., 2004). O Quadro 2.2 apresenta as suas principais formas de ocorrência e exemplos de depósitos relacionados.

Quadro 2.2 - Tipos de minérios auríferos, modo de ocorrência e exemplos

\begin{tabular}{|c|c|c|}
\hline Tipos de minério & Modo de ocorrência do ouro & Exemplos \\
\hline placers & $\begin{array}{l}\text { ouro livre ou liberado nos processos iniciais } \\
\text { com tamanho médio de } 50-100 \mu \mathrm{m}\end{array}$ & $\begin{array}{l}\text { Witwatersrand (África do Sul); } \\
\text { Jacobina (Brasil) }\end{array}$ \\
\hline veios de quartzo & $\begin{array}{l}\text { ouro nativo em veios de quartzo com porções } \\
\text { de telúrio e raramente auroestabite e } \\
\text { maldonita. }\end{array}$ & $\begin{array}{lcr}\text { Timmins } & \text { Camp; } & \text { Hollinger- } \\
\text { Mclntrye (Canadá), } & \text { Muruntau } \\
\text { (Uzbesquistão), Linglong (China) }\end{array}$ \\
\hline oxidados & $\begin{array}{l}\text { ouro ocorre parcialmente liberado com } \\
\text { incremento da liberação em zonas de alteração }\end{array}$ & $\begin{array}{l}\text { Pierina e Yanacocha (Peru), } \\
\text { Yilgarn (Australia) }\end{array}$ \\
\hline minérios ricos em prata & $\begin{array}{l}\text { ouro ocorre como electrum embora kustelita } \\
\text { possa estar presente. }\end{array}$ & $\begin{array}{l}\text { Rochester, Candelaria e } \\
\text { tombstone (EUA); La Coipa } \\
\text { (Chile) }\end{array}$ \\
\hline $\begin{array}{l}\text { minérios de cobre } \\
\text { sulfetado }\end{array}$ & $\begin{array}{l}\text { ouro ocorre como grãos grossos liberados e } \\
\text { finos encapsulado em pirita e sulfeto de cobre }\end{array}$ & $\begin{array}{l}\text { Grasberg (Indonésia); } \\
\text { Tolgoi (Mongólia) }\end{array}$ \\
\hline minérios de ferro & $\begin{array}{l}\text { ouro ocorre como partículas liberadas, mistas } \\
\text { ou inclusas em sulfetos (pirita, marcassita e } \\
\text { pirrotita) ou como grãos submicroscópicos em } \\
\text { sulfetos. }\end{array}$ & Corpos sulfetados \\
\hline $\begin{array}{l}\text { minérios com alto teor de } \\
\text { arsênio }\end{array}$ & $\begin{array}{l}\text { ouro liberado e incluso principalmente em } \\
\text { arsenopirita e produtos oxidados }\end{array}$ & $\begin{array}{l}\text { Giant Yellowknife (Canadá), São } \\
\text { Bento e Morro do Ouro (Brasil) }\end{array}$ \\
\hline minérios telúricos & $\begin{array}{l}\text { ouro ocorre na forma nativa ou em } \\
\text { teluretos/teluratos, podendo estar associadas a } \\
\text { sulfetos. }\end{array}$ & $\begin{array}{l}\text { Cripple Creek, Emperor (Fiji), } \\
\text { Kalgoorlie (Australia) }\end{array}$ \\
\hline minérios carbonosos & $\begin{array}{l}\text { ouro ocorre em finos grãos e submicroscópico } \\
\text { em sulfetos e sua superfície pode adsorver } \\
\text { material orgânico e FeOx }\end{array}$ & $\begin{array}{l}\text { Carlin, Cortez, Getchell, Betze e } \\
\text { Meikle (EUA), Jinya, Gaolong, } \\
\text { Lannigou (China) }\end{array}$ \\
\hline
\end{tabular}

Fonte: adaptado de ZHOU et al., (2004). 
Desde o início dos anos 1980, uma grande quantidade de trabalhos tem sido publicada a respeito da caracterização de minérios de ouro, particularmente minérios refratários (HENLEY, 1989; CHRYSSOULIS et al., 1990; KOJONEN et al., 1999). Por outro lado, os minérios de ouro tidos como "free-milling" vêm sendo cada vez mais explorados e, consequentemente, mais raros, ao passo que os refratários vêm recebendo mais atenção à sua complexidade no processo de beneficiamento.

A forma de ocorrência é de fundamental importância para o tratamento de minérios auríferos. Em um contexto de formação dos depósitos auríferos em ambiente magmático, o ouro, devido às suas propriedades siderófilas (fraca afinidade com silicatos e alta por metais), tende a se concentrar nos fluídos hidrotermais residuais e nas subsequentes fases metálicas e sulfídicas, ao invés da fase silicatada, que se forma nos estágios iniciais de cristalização do magma (MILTZAREK, 2000).

\subsubsection{Formas de associações}

O ouro, devido ao seu caráter pouco reativo, é encontrado na natureza principalmente em sua forma nativa (metálica). Entretanto, sua composição é muito variável em virtude de substituições por outros metais em solução sólidas e apresenta ocorrência em expressivo número de compostos e minerais. A Tabela 2.3 apresenta uma classificação abrangente quanto aos compostos de ouro (ZHOU et al., 2004).

Ouro e prata apresentam grande afinidade e formam soluções sólidas com diferentes proporções. Electrum é um mineral que consiste numa variedade de ouro nativo contendo $25 \%$ ou mais de prata, apresentando o mesmo padrão de estrutura cristalina. Outras variações de ouro podem ocorrer com cobre, paládio e menos comumente, com mercúrio. Outros minerais importantes são a aurostibita ( $\left.\mathrm{AuSb}_{2}\right)$ e minerais com telúrio como a calaverita $\left(\mathrm{AuTe}_{2}\right)$, krennerita $(\mathrm{Au}, \mathrm{Ag}) \mathrm{Te}_{2}$ e aurostibita $\left(\mathrm{AuSb}_{2}\right)$ (HARRIS, 1990). 
Tabela 2.3 - Principais minerais, compostos e conteúdo de ouro

\begin{tabular}{|c|c|c|}
\hline Mineral & Fórmula & Conteúdo de Ouro (\%) \\
\hline ouro nativo & $\mathrm{Au}$ & $>75$ \\
\hline electrum & $\mathrm{Au}, \mathrm{Ag}$ & $50-75$ \\
\hline kustelita & $(\mathrm{Au}, \mathrm{Ag})$ & $<50$ \\
\hline aurostibita & $\mathrm{AuSb}_{2}$ & $43-51$ \\
\hline auricupreto & $\mathrm{Cu}_{3} \mathrm{Au}$ & $50-56$ \\
\hline tetraauricupreto & $\mathrm{CuAu}$ & $70-76$ \\
\hline maldonita & $\mathrm{Au}_{2} \mathrm{Bi}$ & $63-68$ \\
\hline weishanita & $(\mathrm{Au}, \mathrm{Ag})_{3} \mathrm{Hg}_{2}$ & 56.9 \\
\hline anyuiita & $\mathrm{AuPb}_{2}$ & $27-33$ \\
\hline yuanjiangita & AuSn & 62.4 \\
\hline zvyagintsevita & $(\mathrm{Pd}, \mathrm{Pt}, \mathrm{Au})_{3}(\mathrm{~Pb}, \mathrm{Sn})$ & \\
\hline \multicolumn{3}{|c|}{ teluretos e teluratos } \\
\hline calaverita & $\mathrm{AuTe}_{2}$ & $39-44$ \\
\hline krennerita & $(\mathrm{Au}, \mathrm{Ag}) \mathrm{Te}_{2}$ & $30-44$ \\
\hline sylvanita & $\mathrm{AgAuTe}_{4}$ & $24-30$ \\
\hline montbrayita & $(\mathrm{Au}, \mathrm{Sb})_{2} \mathrm{Te}_{3}$ & $38-45$ \\
\hline kostovita & $\mathrm{CuAuTe}_{4}$ & $\sim 25$ \\
\hline \multicolumn{3}{|c|}{ sulfetos e selenetos } \\
\hline liujinyita & $\mathrm{Ag}_{3} \mathrm{AuS}_{2}$ & $18.6-36$ \\
\hline untenbogaardita & $\mathrm{Ag}_{3} \mathrm{AuS}_{2}$ & $27-35$ \\
\hline nagyagita & $\mathrm{Pb}_{5} \mathrm{Au}(\mathrm{Te}, \mathrm{Sb})_{4} \mathrm{~S}_{5,8}$ & 10 \\
\hline fischesserita & $\mathrm{Ag}_{3} \mathrm{AuS}_{2}$ & $\sim 27.3$ \\
\hline
\end{tabular}

Fonte: adaptado de ZHOU et al., (2004).

\subsubsection{Fatores que afetam a extração do ouro}

A opção pela concentração gravítica e flotação no processamento de minério de ouro, pré-tratamento (oxidação por pressão, bioxidação e moagem ultrafina) e extração (lixiviação) depende da forma na qual o grão de ouro se apresenta, seja ele livre, submicroscópico, coloidal ou ainda pelas suas características mineralógicas, tais como tamanho do grão e forma, composição e associação. Na maioria dos depósitos de ouro, o minério passa por algum processo de cominuição para que se obtenha um grau de liberação adequado ao processamento. Assim, os principais fatores que podem afetar a recuperação metalúrgica do ouro são discutidos a seguir.

Tamanho do grão: O tamanho de grão de ouro pode ser um fator significativo na eficiência nos processos de recuperação, principalmente nos processos de 
concentração gravítica. Na etapa de lixiviação, o ouro em granulação grossa pode ser incompletamente lixiviado devido a relação tamanho e tempo de residência. Outro fator é a ineficiência da aderência do grão de ouro às bolhas na flotação e a tendência de acúmulo na base das células de flotação devido à sua alta densidade. Por outro lado, ouro abaixo de $5 \mu \mathrm{m}$ apresenta baixa eficiência na flotação, problema que pode ser ocasionado principalmente pela remoagem do material SIMON et al., (1999). No Figura 2.4, observa-se a relação do tamanho da partícula com a sua recuperação no processo de flotação.

Figura 2.4 - Recuperação de ouro em relação ao tamanho do grão

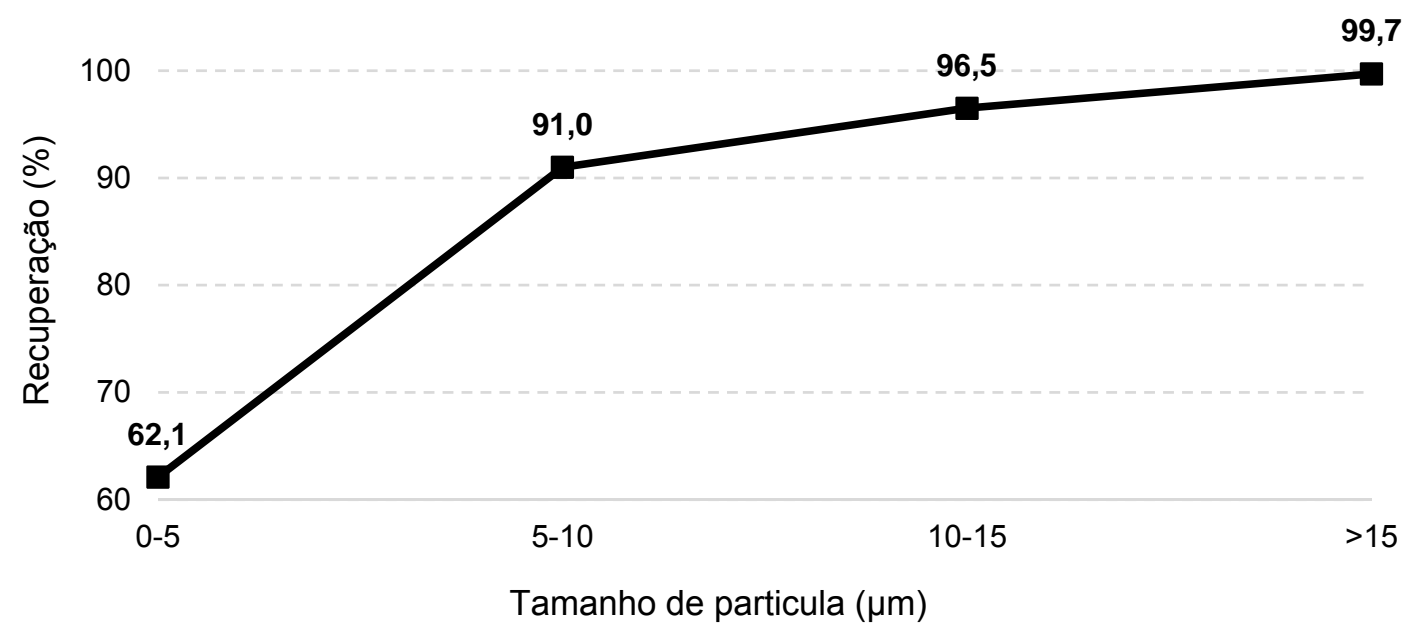

Fonte: adaptado de SIMON et al., (1999).

\section{Recobrimento (slime coating):}

Os minerais argilosos classificados como ganga ocorrem em uma variedade de depósitos de minério de ouro, cobre pórfiro, níquel de baixo teor, minério do grupo da platina, entre outros. Em alguns casos, a proporção de minerais de argila associados aos minérios pode chegar a $80 \%$ (FORBES et al., 2014).

As partículas finas $(<10 \mu \mathrm{m})$, principalmente de argila e óxidos de ferro, podem causar problema na flotação de muitos minerais, principalmente de sulfetos. Essas finas partículas aderem à superfície do mineral hidrofóbico tornando-o hidrofílico, o que dificulta a flotação dessas partículas. As operações unitárias de deslamagem que separam as finas partículas previamente à flotação tem sido usado para minimizar tal efeito (HUYNH et al., 2000). 


\section{Preg-robbing:}

O termo conhecido como preg robbing, refere-se às perdas de ouro pela absorção do complexo aurodicianeto $\left(\mathrm{Au}(\mathrm{CN})_{2}\right)$ da solução cianetada por constituintes do próprio minério. Estes constituintes podem ser matéria carbonosa (carbono amorfo e grafite), clorita, calcopirita (RESS et al., 2000) e minerais argilosos (ilita, caolinita e pirofilita) (ADAMS et al., 1998).

\subsubsection{Beneficiamento mineral}

\subsubsection{Princípios da cominuição}

Os processos de cominuição agrupam um conjunto de operações unitárias que tem por finalidade reduzir, por ação mecânica externa e interna, um sólido de determinado tamanho em fragmentos de tamanho menor. Nesse sentido, a cominuição consiste em estágios de britagem (britadores de mandíbulas, giratórios, cônicos, de impacto e rolos, entre outros), e se aplica desde a mina até a sua adequação ao processo industrial com a moagem (vibratórios, barras, bolas, autógena ou semiautógena, rolos de alta pressão e verticais, entre outros). A depender das características do minério, pode-se utilizar moagem autógena ou semiautógena em combinação com outras operações de cominuição (GALERY, 2011).

Os mecanismos de fragmentação podem ser classificados de acordo com as características do minério e nas etapas na qual o minério se encontra. A britagem é a operação de fragmentação dos blocos maiores obtidos através dos mecanismos de compressão e impacto enquanto que a moagem é um refinamento para a adequação em um produto para o processo industrial (pelotização, lixiviação, combustão, flotação, concentração física, etc). O principal mecanismo atuante na moagem é a abrasão e o produto obtido é da ordem de centenas ou dezenas de micrometros (SILVA, 2012).

Ainda segundo Silva (2012), os principais mecanismos de fragmentação envolvidos na cominuição são:

- Impacto: quando a força é aplicada de forma rápida e com intensidade bem superior à resistência da partícula 
- Compressão: a força é aplica de forma lenta, promovendo a propagação de fraturas que aliviam os esforços

- Atrição/abrasão: a concentração localizada de esforços provoca o surgimento de pequenas fraturas superficiais, com pequena diminuição de tamanho da partícula original e geração de partículas finas.

\subsubsection{Concentração densitária}

A concentração densitária é o processo pelo qual partículas de diferentes tamanhos, formas e massa específica são separadas umas das outras pela força da gravidade ou pela força centrífuga (SAMPAIO et al., 2005). No beneficiamento dos minérios auríferos, devido ao contraste de densidade entre os minerais de minério e os minerais de ganga, a concentração por processos densitários tem importante aplicação.

Este processo tem sua importância assegurada devido às altas tonelagens processadas e, em princípio, por serem os mais baratos em termos de investimento na instalação e custo operacional (CHAVES et al., 2013).

Os principais equipamentos utilizados industrialmente na concentração densitária do ouro são os jigues, as aspirais concentradoras, mesas oscilantes e os concentradores centrífugos.

\subsubsection{Flotação}

A flotação por espuma é uma operação de concentração mineral efetuada pela diferença nas propriedades superficiais das partículas. O método trata misturas heterogêneas de partículas suspensas em fase aquosa (polpas).

A seletividade do processo de flotação se baseia nos distintos graus de hidrofobicidade da superfície de diferentes minerais, ou seja, está associado à sua molhabilidade pela água (PERES, 2007). Partículas mais hidrofóbicas são menos ávidas por água

A separação ocorre quando os minerais que se deseja flotar se tornam hidrofóbicos devido a adição de surfactantes (denominados coletores) que formam uma película hidrofóbica na superfície do mineral, impedindo a hidratação de sua superfície em 
meio aquoso. Na sequência, bolhas de ar são inseridas ao sistema e possibilitam a adesão destas partículas às bolhas e consequente arraste à superfície, sendo removidos da camada de espuma por transbordo. Por sua vez, as partículas hidrofílicas são recobertas por moléculas de água e permanecem na fase aquosa acompanhando o fluxo de água.

Muitos minérios auríferos com comportamento refratário na cianetação direta, apresentam grãos de ouro altamente disseminados ou encapsulados em minerais sulfetados, como pirita e arsenopirita. Um procedimento para minimizar o efeito refratário é o processamento por flotação dos sulfetos (flotação bulk), na qual se tem melhores resultados do que na flotação seletiva do ouro (MARSDEN et al., 1992; BADRI et al., 2013).

\subsubsection{Extração hidrometalúrgica}

Após a obtenção do pré-concentrado do processamento mineral, a extração do metal de interesse (ouro) de sua ganga ocorre pelas reações de dissolução de ouro em meio aquoso. O cianeto utilizado na lixiviação provém de sais, como cianeto de sódio $(\mathrm{NaCN})$, de potássio $(\mathrm{KCN})$ e cálcio $\left(\mathrm{Ca}(\mathrm{CN})_{2}\right)$, sendo os dois primeiros mais utilizados devido à maior solubilidade em água (CIMINELLI, 2002).

\subsubsection{Circuito de cianetação}

O perfeito entendimento das variáveis de processo do circuito de cianetação de determinado minério ou concentrado e de seu inter-relacionamento com as demais componentes, são requisitos básicos para uma operação adequada de cianetação (CIMINELLI, 2002).

A velocidade de reação de dissolução do ouro é dependente das concentrações de cianeto e oxigênio. Além destas concentrações, outras variáveis são: $\mathrm{pH}$, granulometria das partículas, tempo de lixiviação, densidade e concentração de sólidos da polpa, temperatura, pré-aeração e agitação (GOMES, 1999). 


\subsubsection{Adsorção em carvão ativado}

Carvão ativado é uma denominação genérica dada a uma grande quantidade de materiais carbonosos amorfos com elevada área de superfície específica (até 1.200 $\mathrm{m}^{2} / \mathrm{g}$ ) devido à grande quantidade de poros em sua estrutura (GOMES, 1999). O carvão é utilizado para adsorção do ouro em soluções cianetadas e deve ter as seguintes características (FREITAS et al., 2002):

- elevada cinética de adsorção de espécie em fase líquida e capacidade de carregamento;

- resistência a abrasão para garantir um consumo aceitável de carvão e reduzir perda de ouro carregado nos finos de carvão;

- distribuição granulométrica relativamente grossa a fim de facilitar sua separação da polpa por peneiramento.

Os processos a base de carvão ativado, usualmente empregados na indústria para a recuperação do ouro a partir de soluções ou polpa cianetadas, passam por três etapas distintas:

- carregamento: adsorção do cianocomplexo $\mathrm{Au}(\mathrm{CN})_{2}$ nos poros do carvão;

- eluição: dessorção do cianocomplexo, obtendo uma solução mais concentrada;

- produção: extração do metal contido no licor através de eletrólise com zinco.

Os seguintes processos de adsorção em carvão ativado são utilizados industrialmente para a recuperação do ouro a partir de soluções cianetadas (GOMES, 1999; FREITAS et al., 2002):

- CIP (carbon in pulp) - carvão em polpa: carvão ativado entra em contato com a polpa já cianetada, em fluxo contra-corrente;

- CIL (carbon in leaching) - carvão em lixiviação: a adsorção se realiza juntamente com a cianetação e é indicada para minérios que contém material carbonoso;

- CIC (carbon in column) - carvão em coluna: solução cianetada clarificada, proveniente de lixiviação em pilha ou tanques, alimenta uma série de colunas contendo carvão ativado. 
- Lixiviação em pilha (heap leaching) - sistema de extração de ouro por lixiviação em pilha de minério britado na qual é composto por uma base impermeabilizante, tubulações centrais e periféricas e trincheiras também impermeabilizante.

\subsection{CARACTERIZAÇÃO TECNOLÓGICA}

A caracterização tecnológica, termo conhecido em inglês como ore dressing, process mineralogy ou applied mineralogy está intimamente ligada ao estudo de aspectos específicos dos corpos de minério e produtos da usina e fornece subsídios para metalurgistas, engenheiros de processos e geólogos no planejamento de lavra e desenvolvimento e otimização do processo de beneficiamento de minérios (HENLEY, 1983).

O termo caracterização tecnológica está voltada para a avaliação dos parâmetros básicos do corpo mineralizado, relacionado às alternativas tecnológicas de tratamento de minério (SANT'AGOSTINO et al., 1997). Segundo os mesmos autores, a expressão possui um sentido mais amplo na qual se reportam em dois seguimentos tecnológicos distintos: um deles ligado à exploração de lavra ou mina e o outro às técnicas de beneficiamento e processamento na adequação para a indústria de transformação.

Nos estudos de viabilidade e implantação de um empreendimento mineiro, a caracterização é de grande importância pois ajuda na determinação das características mineralógicas dos corpos de minérios, na caracterização do potencial de recuperação e identificação do seu comportamento frente ao processo de beneficiamento.

As aplicações das informações mineralógicas ajudam a entender e resolver problemas durante toda a cadeia mineral, desde a pesquisa mineral até os produtos gerados no beneficiamento ou mesmo na metalurgia. Isso envolve a interpretação dos dados na exploração mineral, processamento, rejeitos, hidrometalurgia, pirometalurgia e refino.

Um fator importante em qualquer técnica analítica é o conceito de amostragem, definida como uma sequência de operações que tem por objetivo retirar uma parte 
representativa da amostra de um dado lote sem inserir mudanças significativas em suas outras propriedades (GY, 1998).

O ouro por ter uma alta densidade $\left(19,3 \mathrm{~g} / \mathrm{cm}^{3}\right)$, é mais susceptível as diferenças no conteúdo da sub-amostra devido forte segregação quando liberadas (CHIEREGATI, 2007).

A Tabela 2.4 apresenta as principais técnicas empregadas na análise de minério de ouro: elas podem ser classificadas em duas categorias: convencional (itens de 1 a 5) e análises instrumentais (itens de 6 a 13).

Tabela 2.4 - Principais técnicas analíticas para análise de ouro

\begin{tabular}{|c|c|c|c|c|}
\hline & Técnica & Abreviação & $\begin{array}{l}\text { Limite de } \\
\text { detecção }\end{array}$ & Aplicação \\
\hline 1 & Fire assay & FA & $0,1-50 \mathrm{ppm}$ & $\begin{array}{l}\text { determinação de ouro em } \\
\text { todas as formas }\end{array}$ \\
\hline 2 & Lixiviação (cianetação) & $\mathrm{CN}$ & - & $\begin{array}{l}\text { recuperação de ouro por } \\
\text { cianeto }\end{array}$ \\
\hline 3 & Concentração gravimétrica & GC & - & $\begin{array}{l}\text { concentração de ouro } \\
\text { gravimétrico }\end{array}$ \\
\hline 4 & Digestão ácida & ADL & - & $\begin{array}{l}\text { determinação de ouro } \\
\text { associado com carbonatos, } \\
\text { sulfetos e silicatos }\end{array}$ \\
\hline 5 & Microscopia ótica & OM & $\sim 0,2-0,5 \mu \mathrm{m}$ & $\begin{array}{l}\text { análise de partículas, } \\
\text { mineralogia, } \\
\text { alterações }\end{array}$ \\
\hline 6 & Imagem automática digital & ADIS & - & $\begin{array}{l}\text { escaneamento e medições - } \\
\text { mineralogia e associações }\end{array}$ \\
\hline 7 & $\begin{array}{l}\text { Microscopia eletrônica de } \\
\text { varredura }\end{array}$ & SEM & semi-quantitativa & $\begin{array}{l}\text { Escaneamento, identificação } \\
\text { mineral, morfologia e } \\
\text { associações minerais }\end{array}$ \\
\hline 8 & $\begin{array}{l}\text { Mineralogia quantitativa } \\
\text { automatizada por feixe de elétrons }\end{array}$ & $\begin{array}{l}\text { Qemscan - } \\
\text { MLA; TIMA: } \\
\text { Mineralogic }\end{array}$ & - & $\begin{array}{l}\text { escaneamento, identificação } \\
\text { mineral, liberação e morfologia } \\
\text { mineral }\end{array}$ \\
\hline 9 & Microanálises química & EPMA & $\begin{array}{l}0,1 \% \text { EDS } 0,02 \% \\
\text { WDS }\end{array}$ & $\begin{array}{l}\text { composição de ouro e outros } \\
\text { minerais }\end{array}$ \\
\hline 10 & $\begin{array}{l}\text { Espectrometria de massa de íons } \\
\text { secundários }\end{array}$ & D-SIMS & ppm & $\begin{array}{l}\text { quantificação e mapeamento } \\
\text { de ouro em sulfetos e FeOx }\end{array}$ \\
\hline 11 & $\begin{array}{l}\text { Emissão de raios } X \text { por indução de } \\
\text { prótons }\end{array}$ & $\mu$-PIXE & ppm & $\begin{array}{l}\text { quantificação e mapeamento } \\
\text { de ouro em sulfetos e silicatos }\end{array}$ \\
\hline 12 & Laser ablation & $\begin{array}{l}\text { LAM-ICP- } \\
\text { MS }\end{array}$ & ppm-ppb & $\begin{array}{l}\text { quantificação de ouro em } \\
\text { sulfetos, silicatos e óxidos }\end{array}$ \\
\hline 13 & $\begin{array}{l}\text { Time of flight espectrômetro de } \\
\text { massa }\end{array}$ & TOF-LIMS & $\mathrm{ppm}$ & $\begin{array}{l}\text { quantificação da área do ouro e } \\
\text { composição química }\end{array}$ \\
\hline
\end{tabular}

Fonte: adaptado de (ZHOU et al., 2004) 
A conexão entre a mineralogia e o desempenho do minério na usina já era descrito desde a década de 1970, com a caracterização de partículas quanto ao tamanho e composição determinada por microscopia eletrônica de varredura (GRANT et al., 1977). Após essa década, houve uma popularização do uso desta técnica juntamente com avanço dos equipamentos e desenvolvimento de sistemas acoplados com EDS e análise de imagens, como QEMSCAN e, posteriormente, o MLA - Mineral Liberation Analyser. Com isso, desenvolveu-se uma plataforma inovadora para a análise de imagens automatizada, hoje complementada por outros sistemas similares - TIMA, Mineralogic e IncaMineral, dentre outros.

Com o avanço a automatização das técnicas quantitativas de análise de imagens, a caracterização tecnológica tem sido utilizada em apoio nos estudos nas áreas de geologia, amostragem, mineralogia e processamento mineral com inúmeros exemplos de desenvolvimento e aplicações sendo publicadas ao longo das últimas décadas (HABERLAH et al., 2011; LOTTER, 2011).

\subsubsection{Estereologia e análise de imagens}

Estereologia é definida como o estudo de estruturas tridimensionais a partir de imagens bidimensionais, normalmente com a utilização de seções planas (RUSS, 1986).

A análise de imagens tem sido usada no ramo de mineralogia aplicada para determinação da mineralogia quantitativa, grau de liberação mineral, distribuição granulométrica de grãos, partículas e suas inclusões, associações minerais, entre outras características relacionadas à sua morfologia (PETRUK, 2000). Para FORTEY (1995), o termo se refere à análise computacional das informações quantitativas coletadas de forma digital.

A análise de imagem foi um campo que se expandiu rapidamente devido aos avanços na computação, algoritmos e no aprimoramento das técnicas de microscopia. Em geral, o método envolve a análise computacional bidimensional e são determinadas de forma direta, por uma variedade de métodos de análise de imagens incluindo estimativa visual, contagem de grãos, intercepto linear, medidas de área e outras (HENLEY, 1983). 


\subsubsection{Erros associados às análises de imagens}

Existem muitas fontes de erro que podem ser relacionados à análise de imagens. Esses erros podem estar relacionados ao erro fundamental, que é o menor erro existente para uma amostra coletada em condições ideais, ou ainda erro relacionado à preparação da amostra e estatística das partículas.

RUSS (1986) considera que, como na maioria das medições há erros resultantes de viés nas técnicas utilizadas, torna-se necessário o uso de métodos estatísticos para avaliar a magnitude desses erros. O emprego de métodos automatizados de análise de imagens permite aumentar substancialmente o número de dados e, em consequência, ter maior robustez na análise estatística, minimizando o erro (JONES, 1987).

Um erro estereológico na análise uni e bidimensional pode resultar em dados superestimados conforme a posição em que a partícula é cortada e exposta. Dependendo da posição em que a partícula é seccionada, a seção exposta pode não representar as proporções médias das fases presentes. Na Figura 2.5, as três seções na partícula representam graus de liberação diferentes, apresentando partículas totalmente livres (partícula 1) e partículas mistas (partícula 3) (FANDRICH et al., 1998).

Figura 2.5 - Partícula binária seccionada em distintas regiões

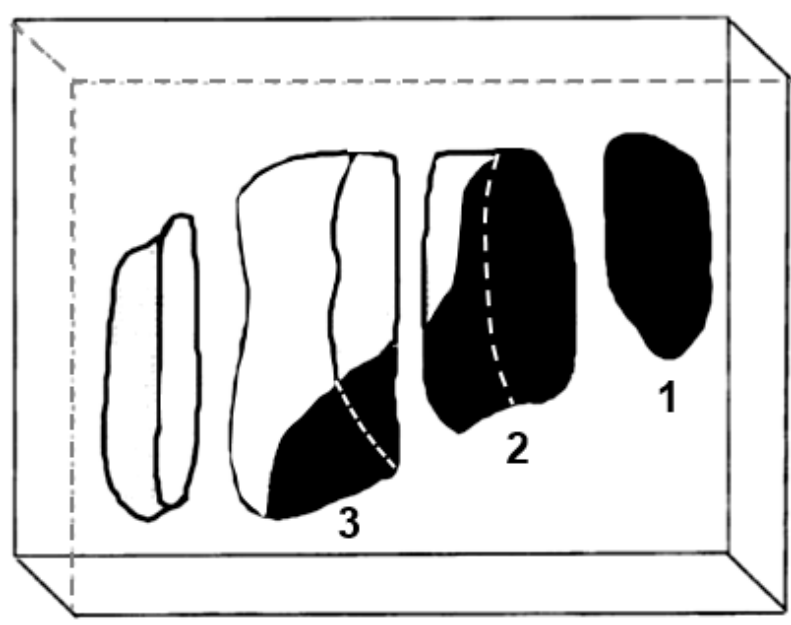

Fonte: modificado de FANDRICH et al., 1998. 
2.4.3 Microscopia eletrônica de varredura e mineralogia quantitativa automatizada

As ferramentas de análise de imagens quantitativas automatizadas vêm evoluindo ao longo dos últimos anos tornando-a mais robusta, rápida e com maior confiabilidade na geração de dados estatísticos confiáveis (PETRUK, 1989; FANDRICH et al., 2007).

Técnicas de microscopia óptica (MO) utilizadas em estudos mineralógicos em rochas, minérios e produtos de processamento mostram baixa robustez estatística, elevado tempo na coleta e baixo nível de detalhe. A microscopia eletrônica de varredura (MEV) é uma poderosa ferramenta por meio da qual é possível alcançar um nível de detalhe tanto maior quanto o seu poder de magnificação em relação à microscopia óptica.

As imagens geradas com detector de elétrons retroespalhados (BSE) permitem a distinção entre as fases presentes pela diferença de número atômico médio, representado pelos distintos tons de cinza; esta informação pode ser complementada com composição química pontual obtida a partir de espectrômetros por dispersão de energia (EDS) para a facilitar a identificação de minerais presentes em uma amostra (GRANT et al., 1977). Outros detectores permitem a obtenção de informações como a catodoluminescência. Esse tipo de técnica permite observar diferenças composicional em uma mesma partícula de um determinado mineral através de elétrons secundários (GÖTZE, 2002).

A aplicação de mineralogia automatizada na exploração mineral é uma área relativamente nova, com aplicações que incluem o grupo da platina, ouro, minerais metálicos (DOBBE et al., 2009; AYLING, 2011).

Os dois principais sistemas comerciais de análise de imagem automatizada existentes no mercado são o MLA (Mineral Liberation Analyser) e o QEMSCAN (Quantitative Evaluation of Minerals by Scanning Electron Microscopy), ambos atualmente comercializados pela empresa FEI. Outros sistemas similares foram introduzidos mais recentemente, tais como o TIMA (TESCAN), o INCAMineral (Oxford) e o Mineralogic (Zeiss). A seguir é apresentado uma descrição sucinta dos sistemas supracitados: 
- QEMSCAN ${ }^{13}$ (Quantitative Evaluation of Minerals by Scanning Electron Microscopy): emprega uma plataforma de microscopia eletrônica de varredura (MEV) com uma fonte de feixe de elétrons em combinação com hardware exclusivo controlando até quatro detectores de energia dispersiva de raios $\mathrm{X}$ (EDS) (GOTTLIEB et al., 2000).

- MLA $^{14}$ (Mineral Liberation Analyser): sistema de automação controla o sistema de EDS; o grande diferencial inicial do sistema MLA é o mecanismo que permitia combinar análise de imagens por elétrons retroespalhados (BSE) e espectros de raios $X$ característicos (GU, 2003).

- TIMA ${ }^{15}$ (TESCAN Integrated Mineral Analyzer): é um sistema de análise de imagens automatizada integrado ao microscópio eletrônico de varredura desenvolvido essencialmente para coleta de BSE e EDS.

- INCAMineral ${ }^{16}$ (Oxford Instruments): módulo complementar ao INCAFeature que permite combinação de imagens e de raios $X$ para a obtenção de dados de mineralogia modal, grau de liberação entre outros.

Esses sistemas possibilitam detalhar as características quantitativas de forma automatizada em curto espaço de tempo, com a coleta de um volume expressivo de informações como composição química e mineralógica, partição dos elementos químicos, associações minerais, liberação e distribuição de partículas mistas.

O princípio básico consiste na segmentação das fases minerais através da distinção de tons de cinza (contraste de número atômico - imagem de BSE) e aquisição de espectros de raios $X$ em cada feição discriminada para posterior classificação dos minerais mediante comparação com um banco de padrões pré-definido, como exemplificado na Figura 2.6.

\footnotetext{
${ }^{13} \mathrm{http}: / / \mathrm{www}$. fei.com/products/sem/qemscan/

${ }^{14} \mathrm{http}: / / \mathrm{www}$.fei.com/products/sem/mla/

${ }^{15} \mathrm{http}: / / \mathrm{www}$. tescan.com/en/products/tima/tima-Im

${ }^{16} \mathrm{http}: / / \mathrm{www}$.oxford-instruments.com/products/microanalysis/solutions/mineral-liberation
} 
Figura 2.6 - Esquema geral de classificação no MLA
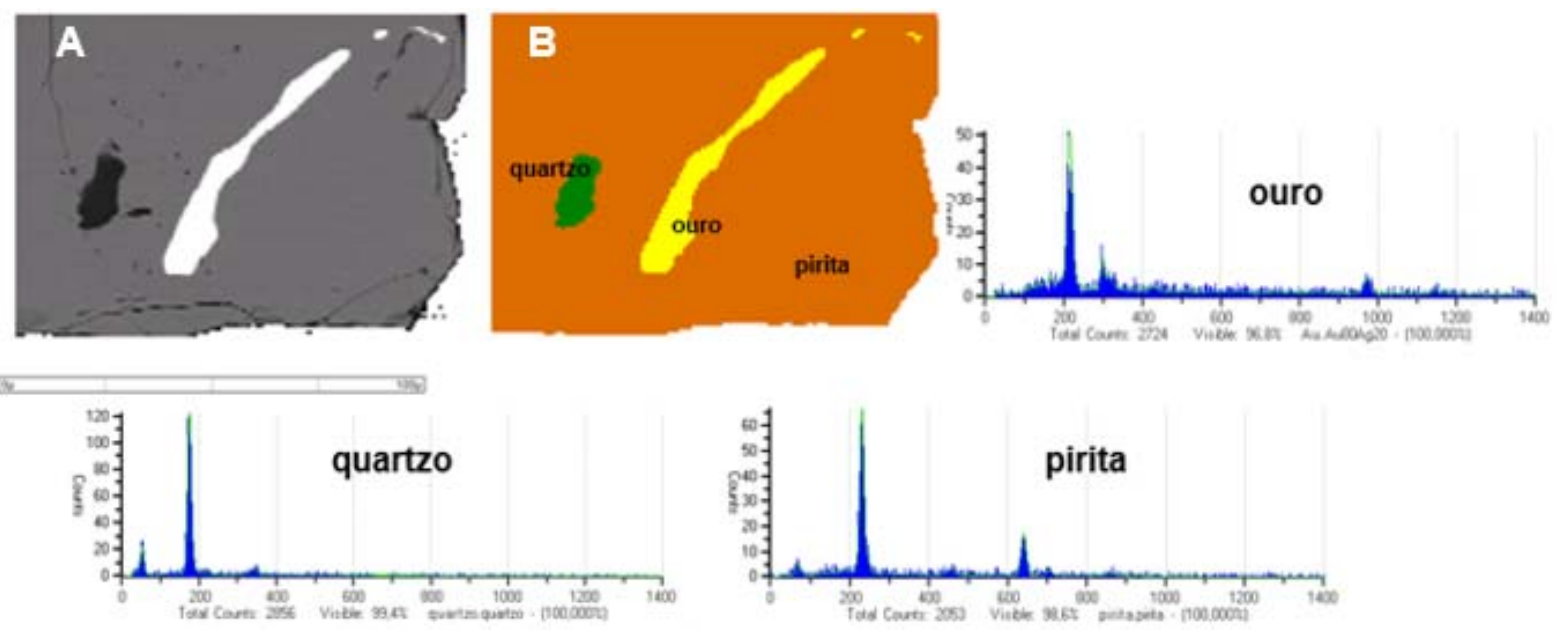

Legenda: A foto A: mostra a imagem de BSE - contraste de número atômico. Nela é possível observar pelo menos 3 fases minerais distintas indicadas pelos tons de cinza. A imagem $B$, indica a segmentação e classificação dos minerais mediante comparação do banco de padrões pré-definido obtido pelos espectros das diferentes fases minerais (ouro, quartzo e pirita).

A partir das imagens digitais geradas e processadas, através de algoritmos próprios, estes sistemas são capazes de compilar em um banco de dados todas as informações relativas a cada partícula e grão mineral discriminado na análise.

\subsubsection{Grau de acessibilidade do ouro}

As operações unitárias de cominuição e concentração têm por objetivo a obtenção de um produto dentro da especificação para o aproveitamento industrial. As operações por separações e concentração são baseadas em diferenças físicas ou físicoquímicas entre as espécies minerais e as suas propriedades diferenciadoras, como a densidade (concentração densitária), susceptibilidade magnética (concentração magnética) e propriedades de superfície (flotação, separação eletroestática). A eficiência na separação de componentes de um material depende da precisão do processo de concentração e será mais eficiente onde as fases minerais encontrem-se individualizadas ou livres, pois desta forma as diferenças entre as mesmas são mais evidentes.

Existe uma relação entre liberação e fragmentação, ou seja, quanto mais fina a fragmentação, maior probabilidade das partículas estarem liberadas. Porém, a 
fragmentação deve ser limitada ao estritamente necessário devido ao custo elevado das operações de cominuição e o desempenho insatisfatório de partículas ultrafinas (abaixo de $10 \mu \mathrm{m}$ ) nos processos de concentração.

A Fotomicrografia 2.1 apresenta diferentes graus de perímetro exposto para percolação de uma solução cianetada. Note que a figura, o grão de ouro mesmo não sendo livre possui um facilitador para percolação da solução, tornando-o acessível.

\section{Fotomicrografia 2.1 - Ilustração sobre a acessibilidade do ouro}

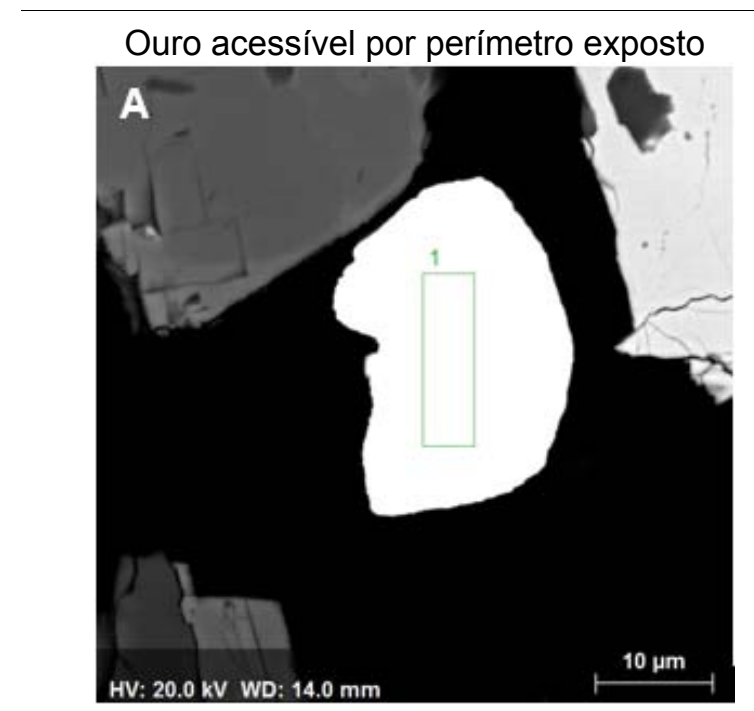

Ponto: Au (1)

perímetro parcialmente exposto e acessível

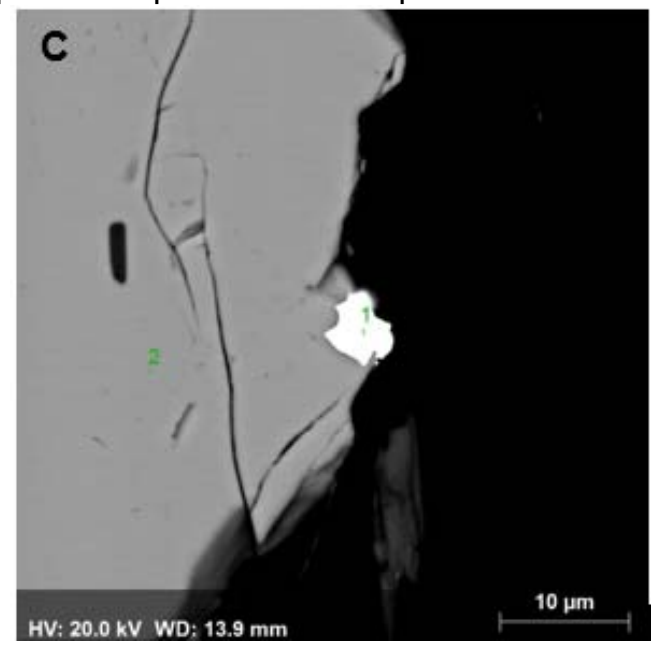

Pontos: Au (1), arsenopirita (2)

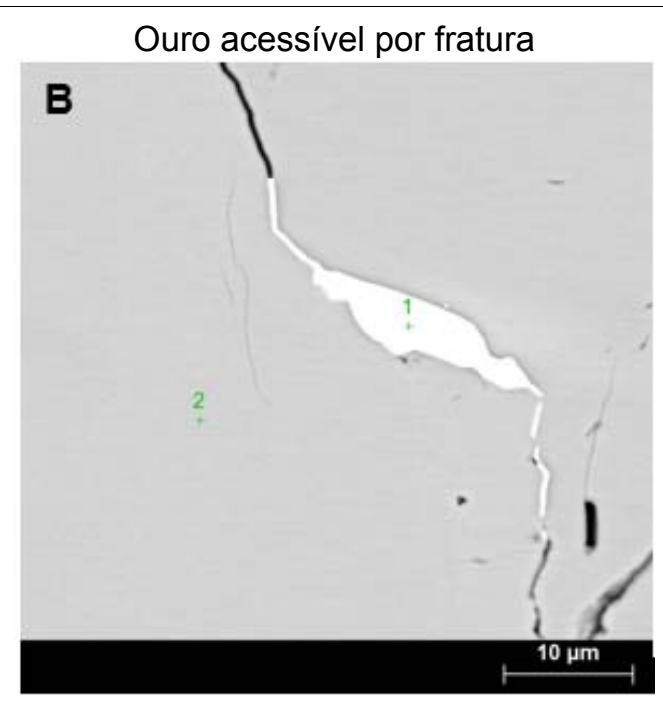

Pontos: Au (1); pirita (2)

perímetro parcialmente exposto e acessível

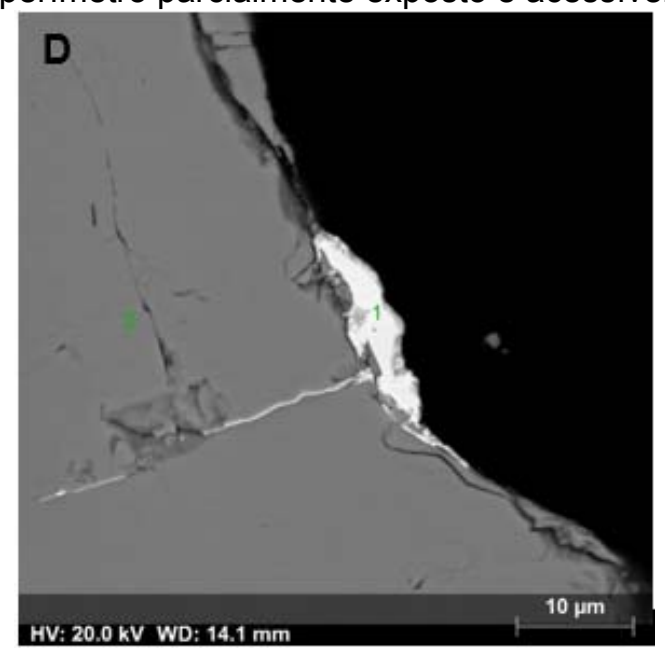

Pontos: Au (1), arsenopirita (2)

Legenda: Imagem A: grão de ouro totalmente livre, o que indica ser $100 \%$ recuperável e $100 \%$ exposto. Imagem B: grão de ouro com mínima porção exposta e acessível, passível de ser lixiviada. A associação mineral é inteiramente composta por pirita. Imagem C e D: grãos de ouro associado a arsenopirita com aproximadamente $40 \%$ (C) e $70 \%$ de superfície exposta (D). 
Adicionalmente para minérios auríferos, o conceito clássico de grau de liberação descrito por Gaudin (1939), perde o seu significado quando os processos empregados para a sua recuperação e extração se baseiam em propriedades específicas desse elemento, como por exemplo, a formação de amálgamas com mercúrio e lixiviação por soluções alcalinas de cianeto. A definição clássica para liberação mostra que numa população de partículas de diferentes espécies minerais, o grau de liberação de uma das espécies consiste no percentual deste mineral que ocorre como partículas livres em relação ao total de partículas (mistas ou livres). Já o grau de associação corresponde ao percentual do mineral que se encontra misto (duas ou mais fases) em relação ao total (GAUDIN, 1939).

O ouro amalgamável constitui a parcela de ouro em relação ao ouro total contido passível de ser recuperada por processos densitários, seguidos de amalgamação pelo mercúrio. Para Tassinari (1996), a amalgamação é ineficiente para extração de ouro fino com limites de aplicação de $10 \mu \mathrm{m}$ em condições operacionais usuais de processamento mineral. Por outro lado, em condições controladas de laboratório é possível recuperar as partículas de ouro liberadas até a granulação de $40 \mu \mathrm{m}$ e também de partículas mistas em que o ouro constitua mais de $10 \%$ do perímetro exposto. O ouro passível de ser lixiviado é a parcela de ouro na qual se encontra com algum perímetro exposto a soluções alcalinas de cianeto, seja na superfície ou incluso em partículas cujo ouro seja acessível por microfraturas.

A Fotomicrografia 2.2 apresenta diferentes formas de inclusão dos grãos de ouro em imagem bidimensional (2D). Em ambos os exemplos, não seria possível a ação da solução, pois não há um meio facilitador/condutor para a percolação. Por se tratar de uma observação bidimensional, o ouro pode ser passível de extração por caminhos localizados em uma outra parte do grão, não visualizada na imagem. Assim, a informação de acessibilidade do ouro por análise de imagem pode ser subdimensionada.

Por critério, o termo "perímetro exposto" será definido como sendo a porção dos grãos de ouro passíveis de serem extraídos por ação de uma solução lixiviante, o que, em relação à sua superfície, apenas 1 pixel exposto configura o potencial de extração. 
Fotomicrografia 2.2 - Ouro potencialmente não extraído - 2D

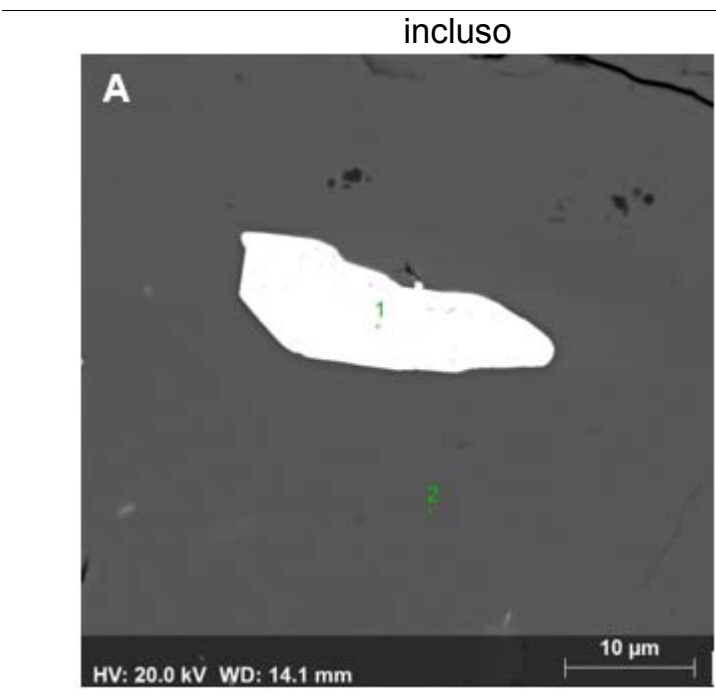

Pontos: Au (1), pirita (2)

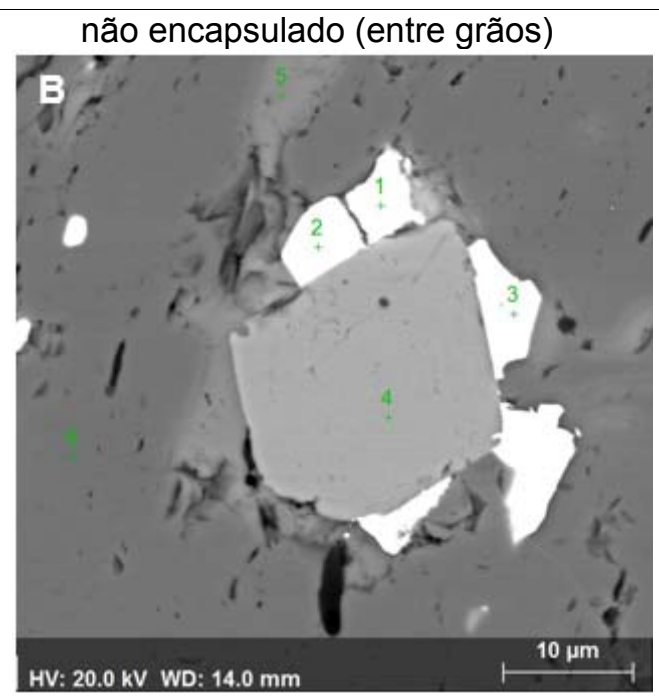

Pontos: galena (1 e 2), ouro (3), arsenopirita (4), (calcopirita (5) e pirita (6).

Legenda: Imagem A: grão de ouro incluso na pirita. Por se tratar de uma imagem 2D, não é possível observar possíveis fraturas em outras posições da partícula. Imagem B: partícula mista com grãos de ouro em contato com duas ou mais fases. Essa situação é classificada como grãos de ouro não encapsulados.

\subsubsection{Difração de raios $X$}

A técnica de difração de raios X (DRX) apresenta uma grande variedade de aplicações em diversos campos do conhecimento correspondendo a uma das principais técnicas de caracterização de materiais cristalinos. Pode ser empregada na engenharia e ciências dos materiais, metalurgia, mineração, química e geociências, além de outras áreas do conhecimento.

Considerando pelo menos dois planos cristalinos, uma parcela dos raios $\mathrm{X}$, ao atingir a superfície do material, sofre espalhamento elástico sem perda de energia (dispersão ou espalhamento coerente), ou seja, a difração dos raios $X$ vai depender da diferença do trajeto percorrido entre dois planos "d", o comprimento de onda da radiação incidente " $\theta$ " e o comprimento da onda da radiação incidente " $\lambda$ “. Essa condição é expressa na equação de Bragg (eq. 1) (BISH et al.,1989).

A Lei de Bragg e o fenômeno de interação é expressa a seguir (Figura 2.7).

$$
\mathrm{n} \lambda=2 \mathrm{~d} \operatorname{sen} \theta
$$


onde $\lambda$ : corresponde ao comprimento de onda da radiação incidente, " $n$ " à ordem de difração, "d" à distância entre planos para o conjunto de planos hkl (índice de Miller) da estrutura cristalina e $\theta$ ao ângulo de incidência dos raios $X$.

Figura 2.7 - Ilustração do fenômeno de difração de raios X

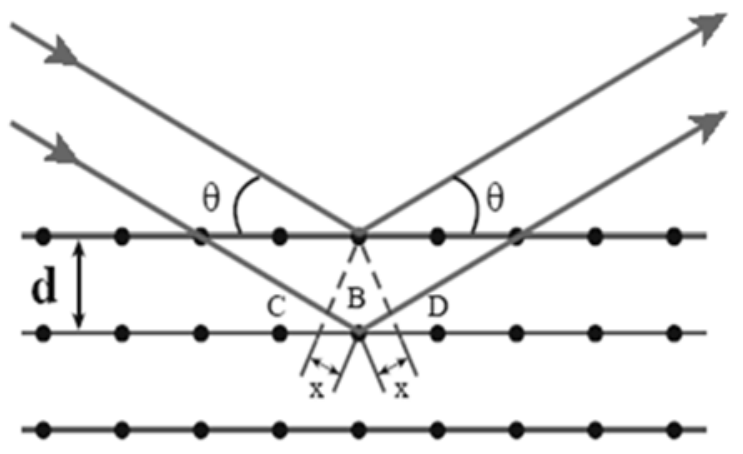

Fonte: Modificado de BISH et al., (1989)

Os instrumentos mais usuais de medida da difração de raios $X$ em materiais geológicos são os difratômetros com análises de amostras pulverizadas (método do pó) (JENKINS, 1989). A identificação das fases cristalinas, de minerais, metais ou outros constituintes, é realizada a partir da comparação do difratograma coletado com fichas catalogadas em bancos de dados de estruturas cristalinas disponíveis e elaboradas pelo ICDD $^{17}$ e outras instituições.

\subsection{DEPÓSITO DE MORRO DO OURO}

\subsubsection{Histórico da exploração de ouro no Morro do Ouro}

A descoberta do ouro de aluvião no início do século XVIII, próximo a um pequeno córrego junto ao Morro da Cruz das Almas, hoje Morro do Ouro, propiciou o surgimento da atual cidade de Paracatu, a noroeste do estado de Minas Gerais.

Como ocorreu em toda a colônia, a mão de obra na sua totalidade era escrava e seu desenvolvimento logo entrou em crise devido à escassez do ouro de aluvião frente aos novos desafios de desenvolvimento em uma área com rocha de dureza maior.

${ }_{17}$ ICCD: International Centre for Diffraction Data 
Assim, foi necessário o desenvolvimento tecnológico e de equipamentos para manter a prosperidade econômica na região.

No período de 1752 e 1787 houve um pico de produção de ouro em Paracatu. Documentos indicam que a partir de 1787, as jazidas já estavam em "estado de exaustão" e o então governador D. Luiz da Cunha Meneses ordenava o confisco dos bens de vários mineradores da cidade por falta de pagamento de impostos (CARVALHO, 1992).

A partir dessa data, vários exploradores a mando da coroa passaram pela região. Segundo o explorador austríaco POHL "a região de Paracatu é pobre, despida de atrativos. A extração é atualmente insignificante, por falta de água para lavagem, limita-se à estação chuvosa". Como o Córrego Rico, nome proveniente da extinta abundância de ouro não justifica mais essa denominação, os donos de escravos foram obrigados a retirá-los das lavras para empregá-los no cultivo do campo.

O declínio da produção aurífera e as suas consequências, como a transferência da população urbana para a zona rural, fez florescer a atividade agropecuária na região. Essa nova atividade lançou as bases para o povoamento regional e desenvolvimento frente a estagnação da produção mineral. Apesar do franco declínio, a região manteve uma atividade pontual de garimpagem que sempre estava presente na rotina da cidade na forma de subsistência.

Somente a partir de 1970, Paracatu passou a atrair a atenção das empresas de exploração mineral, porém sem resultados imediatos, visto que a maioria delas não se sentiram atraídas pelo baixo teor do minério, considerado como não econômico.

Em 1984, a mineradora inglesa Rio Tinto (antes, Rio Tinto Zinc - RTZ) com base em uma pesquisa fundamentada na escavação e amostragem de algumas centenas de poços profundos intensificou os trabalhos para a viabilização da instalação do empreendimento mineiro. Em 1987, a Rio Tinto acertou com a Autram Mineração e Participações (antes TVX Gold Inc) a participação como sócia do empreendimento. Esta associação fez surgir numa nova empresa, Rio Paracatu Mineração S/A, cujo capital passou a ser de $51 \%$ da RTZ e $49 \%$ da Autram. 
A Rio Paracatu Mineração iniciou a sua operação em 1988 com a construção da usina de beneficiamento I sob um capital inicial de 65 milhões de dólares.

Em dezembro de 2004, a companhia canadense Kinross Gold Corporation adquiriu a parcela da mina pertencente a Rio Tinto. Após a aquisição pela Kinross, o empreendimento passou por diversas fases de expansão, chegando à maior produtora de ouro nacional com produção de 520 mil onças de ouro em 2014, uma reserva de 6,541 koz (provada) e um teor médio de $0,41 \mathrm{~g} / \mathrm{t}$.

\subsubsection{Enquadramento geológico-geotectônico}

Este item propõe apresentar uma síntese da evolução geotectônica regional da área de estudo. Essa síntese é resultado da integração de dados estruturais, estratigráficos e geoquímicos.

A Faixa Brasília, na qual a área de estudo faz parte, é um sistema orogênico neoproterozóico situado entre os crátons Amazônico e São Francisco, desenvolvido no contexto colisional que culminou na amalgamação do supercontinente Gondwana. A Faixa Brasília bordeja o Cráton do São Francisco (CSF) enquanto as faixas Paraguai e Araguaia, bordejam o Cráton Amazônico.

MARINI et al., (1981); FUCK (1994) e DARDENNE (2000) definiram a faixa (Figura 2.8) como um conjunto de terrenos acrescidos associados à empurrões de escala crustal que convergiram para leste contra o Cráton do São Francisco. Essa faixa é marcada por dois segmentos distintos: a Faixa Brasília Setentrional (FBS), que tem como característica a orientação NE, e a Faixa Brasília Meridional (FBM) de orientação NW, limitadas pela Megaflexura de Pireneus.

A faixa externa da FBM é marcada por empilhamento tectônico de vários terrenosestratigráficos limitados por importantes superfícies de cavalgamento, a maioria das quais representadas majoritariamente por unidades litoestratigráficas metassedimentares, tais como os grupos Vazante (inferior), Canastra, Ibiá, Paranoá e Araxá-Andrelândia (Superior). Descontinuidades metamórficas podem ocorrer entre os terrenos adjacentes. 
O Grupo Canastra (ALMEIDA, 1967) compreende lascas tectônicas, separadas por falhas de empurrão, compostas por sequências de metassedimentos detríticos representados por quartzitos e filitos com fácies carbonatadas subordinadas. Foi metamorfisada em condições de fácies xisto verde. Segundo BARBOSA et al. (1969), a rochas originaram-se em um contexto bacinal de margem passiva, com sedimentos provenientes possivelmente do Cráton do São Francisco.

Figura 2.8 - Mapa Geológico da Faixa Brasília

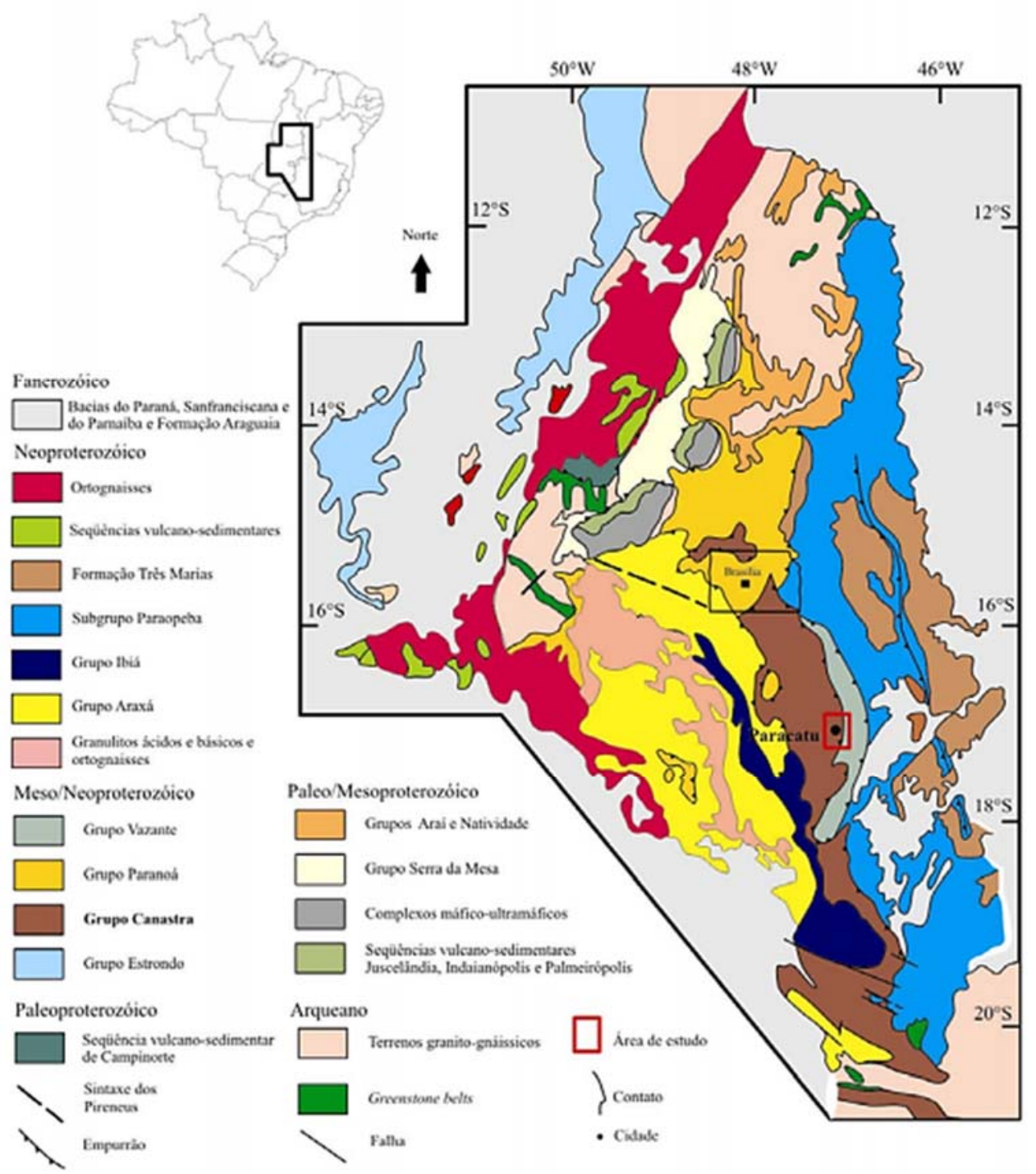

Mapa da geologia regional da Faixa Brasília (FUCK et al., 1994).

DARDENNE (2000) dividiu o Grupo Canastra em duas formações (Figura 2.9): Formação Paracatu e Serra do Landim. A Formação Paracatu é formada por filitos carbonosos cinza escuro com algumas intercalações de lentes de quartzitos. Este 
Grupo se sobrepõe ao Grupo Vazante através de falhamentos inversos e contatos normais ou transicionais com evidências que sugerem a deposição de sedimentos químicos de águas profundas com intercalações de sedimentos terrígenos. A partir desta constatação, Zini (1988) dividiram a Formação Paracatu em dois membros, denominadas Membro Morro do Ouro e Membro Serra da Anta.

Figura 2.9 - Coluna estratigráfica dos grupos Canastra, Vazante e lbiá

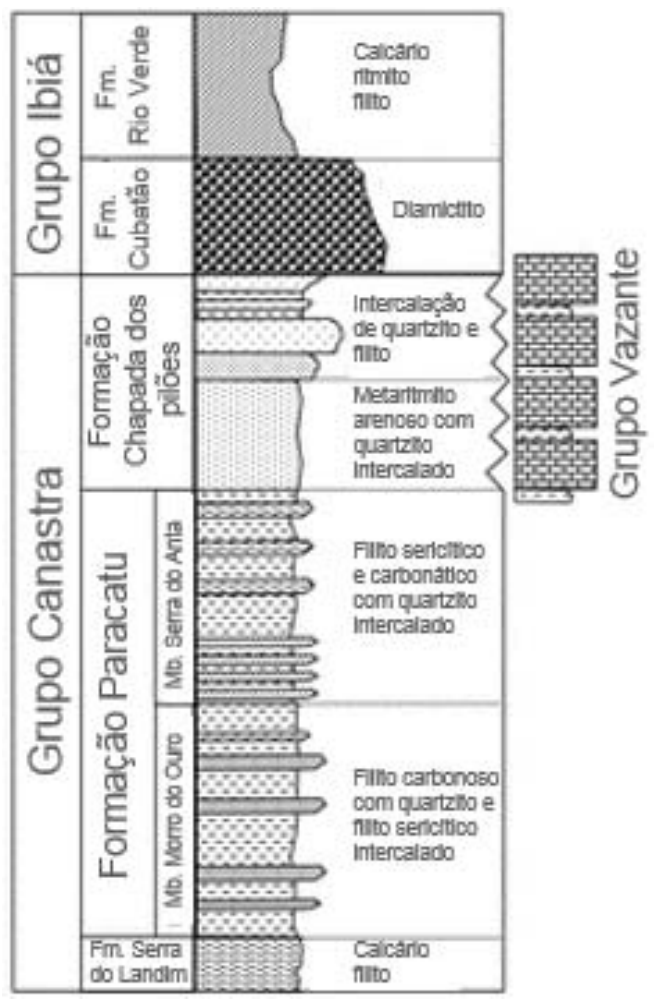

Legenda: Coluna estratigrafia mostrando uma progressiva sequência clástica rasa do Grupo Canastra no qual, próximo da base, é denominado por folhelhos negros metamorfizado em fácies xisto verde (OLIVER et al,. 2015).

O Membro Morro do Ouro, porção inferior da Formação Paracatu, é formada por filitos carbonosos cinza escuro com lentes milimétricas a centimétricas de quartzito. Nesse pacote inferior hospeda-se a mineralização aurífera do depósito do Morro do Ouro. Por sua vez, o Membro Serra da Anta, porção superior, é representada por filitos cinza claro e metasiltito com diminuição das lentes de quartzito.

A Formação Serra do Landim, que compõe a unidade basal do Grupo Canastra, é composta por filitos verdes calcíferos e tem aproximadamente 250 metros de espessura. Foi inicialmente atribuída à Formação Vazante (MADALOSSO et al., 
1978), (MADALOSSO, 1980), porém FREITAS SILVA, (1996) a correlacionou ao Grupo Canastra.

Na Faixa Brasília, os principais depósitos minerais neoproterozóicos são associados ao Arco Magmático de Goiás, com mineralizações de ouro, cobre e esmeraldas; às sequências metassedimentares dos grupos Vazante e Bambuí, com presença de fosfato, chumbo e zinco; às zonas de cisalhamento regionais, com contribuição de ouro e complexos máficos-ultramáficos, nos quais estão presentes mineralizações de cobre, níquel e cobalto.

\subsubsection{Geologia local}

O depósito aurífero Morro do Ouro está inserido no Grupo Canastra, Formação Paracatu, Membro Morro do Ouro, no qual se apresentam filitos deformados com boudins de quartzo que caracterizam o corpo mineralizado, conforme Figura 2.10. A deformação dos filitos é traduzida em estruturas do tipo kink bands, slickensides e sigmoides com sombra de pressão e concentrações sulfetadas.

O depósito está hospedado em filitos carbonosos cinza claro a escuro marcado pela intercalação de níveis de filossilicatos, compostos essencialmente por clorita e lentes de quartzito milimétricas a centimétricas com foliação predominantemente na direção média de $\mathrm{N} 20-40^{\circ}$ mergulhando $10^{\circ} \mathrm{SW}$.

Figura 2.10 - Amostras do depósito Morro do Ouro
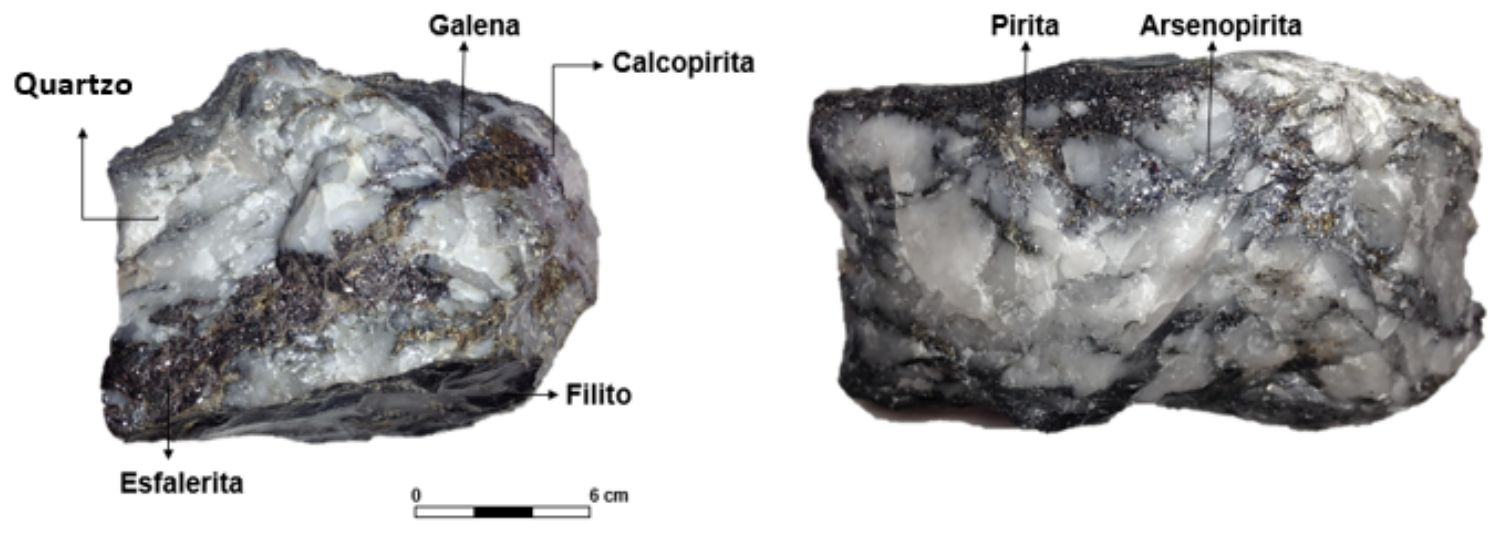

Legenda: Boudins de quartzo com calcopirita, galena, esfalerita, pirita e arsenopirita. Em alguns locais os boudins de quartzo ocorrem laminados com núcleos carbonáticos. 
Juntamente com as estruturas do tipo boudin, ocorre clivagem de crenulação e zonas de sombra de pressão associadas ao estrangulamento das camadas quartzosas. Nas crenulações ocorrem lineações de estiramento com caimento da ordem de $10-15^{\circ}$ para WSW, contidas na foliação, indicando transporte de massa para NE (MYASHITA, 2005).

A mineralização ocorre preferencialmente associada aos boudins de quartzo, nos quais estão contidos os sulfetos e, em menor proporção, carbonatos e silicatos. Os sulfetos (arsenopirita, pirita, galena, pirrotita, etc) podem ocorrer de forma disseminada nos filitos ou ainda em maior proporção, maciça, associados aos boudins de quartzo (DAITX \& ZANARDO 2000).

\section{Figura 2.11 - Seção esquemática do depósito Morro do Ouro indicando horizontes mineralizados.}

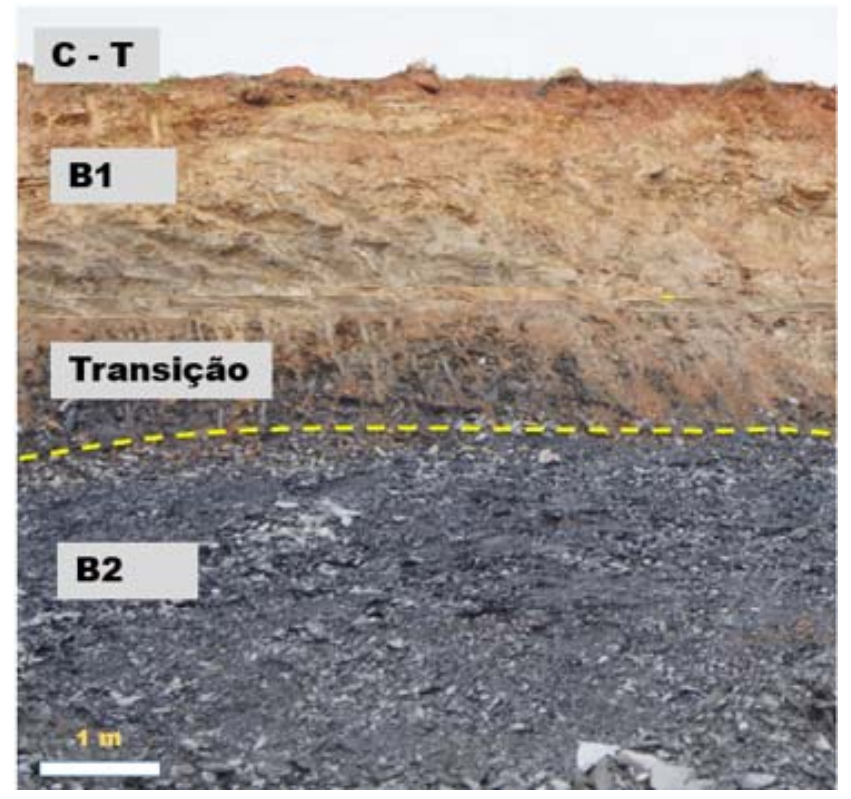

Legenda: Horizontes C e T correspondem aos níveis superficiais. B1 indica minério oxidado e B2, minério sulfetado. A linha amarela indica a zona de transição entre os níveis B1 e B2, localmente denominada B2 friável.

Foram estabelecidos quatro horizontes estratigráficos (Figura 2.11): C, T, B1 e B2, do topo para a base. Os horizontes C, T e B1 constituem a porção oxidada do corpo mineralizado, ao passo que a Unidade B2 representa a parte primária, sulfetada de maior dureza e variável com a profundidade considerada. A espessura do perfil intempérico é variável, não passando de 2 metros e ocorre em função da topografia, 
da intensidade da sulfetação primária e do conjunto de falhas e lineamentos (MOLLER et al., 2001).

A porção oxidada pode atingir pouco mais de 40 metros de espessura em algumas zonas do depósito, principalmente na porção central. O horizonte $\mathrm{C}$ corresponde à rocha completamente alterada, oxidada. O horizonte B1 se refere à rocha menos decomposta, com uma dureza maior em relação ao horizonte $\mathrm{C}$.

O horizonte $\mathrm{T}$ faz parte da transição do $\mathrm{C}$ para o $\mathrm{B} 1$, com cores variáveis e tem espessura de poucos metros $(2 \mathrm{~m})$. As reservas que viabilizaram o empreendimento mineiro de Morro do Ouro referiam-se exclusivamente ao minério dos horizontes $\mathrm{C} \mathrm{e}$ $\mathrm{T}$, para o qual foi definido um teor médio de 0,59 ppm de ouro. Hoje, apenas um remanescente do minério do tipo B1 é lavrado sendo o minério B2 fonte de avaliação de recursos e reservas para a empresa (teor médio de 0,410 g/t).

O minério denominado B2 foi estabelecido com base nos critérios: grau de deformação estrutural, teor em arsênio, textura dos sulfetos, tipos de sulfetos, grau de silicificação. Com base nestes critérios foram identificados corpos com uma relação direta entre teor de arsênio e ouro contido (MOLLER et al., 2001). Diante dessa relação, estabeleceram-se os seguintes corpos de minério (seção esquemática apresentada na Figura 2.12 para o minério B2):

- B2 com teor de arsênio menor que 2500 ppm. O filito ocorre pouco deformado, com o sulfeto disseminado (pirita e pirrotita > arsenopirita) geralmente apresenta textura fina. Teor de ouro é relativamente baixo em relação aos outros corpos mineralizados.

- B2 com teor de arsênio entre 2500 e 4000 ppm. Refere-se ao minério que constitui os corpos com maior proporção de sulfetos e com estruturas mais deformadas (sigmóides, kink bands e boudins deformados) que o minério com teor de arsênio abaixo de 2500 ppm. Este minério representa cerca de $25 \%$ dos recursos totais de minério $B 2$.

- B2 com teor de arsênio maior que 4000 ppm. Refere-se ao minério que preferencialmente ocorre na zona mais central envelopados por níveis de baixo teor de arsênio. Ocorrem de forma descontínua e é pouco espesso dentro do pacote de teor de arsênio de 2500-4000 ppm. São, via de regra, muito 
deformados e sulfetados. São denominados de calha IDS (intensamente deformada e sulfetada).

Figura 2.12 - Seção esquemática do corpo de minério tipo B2

S

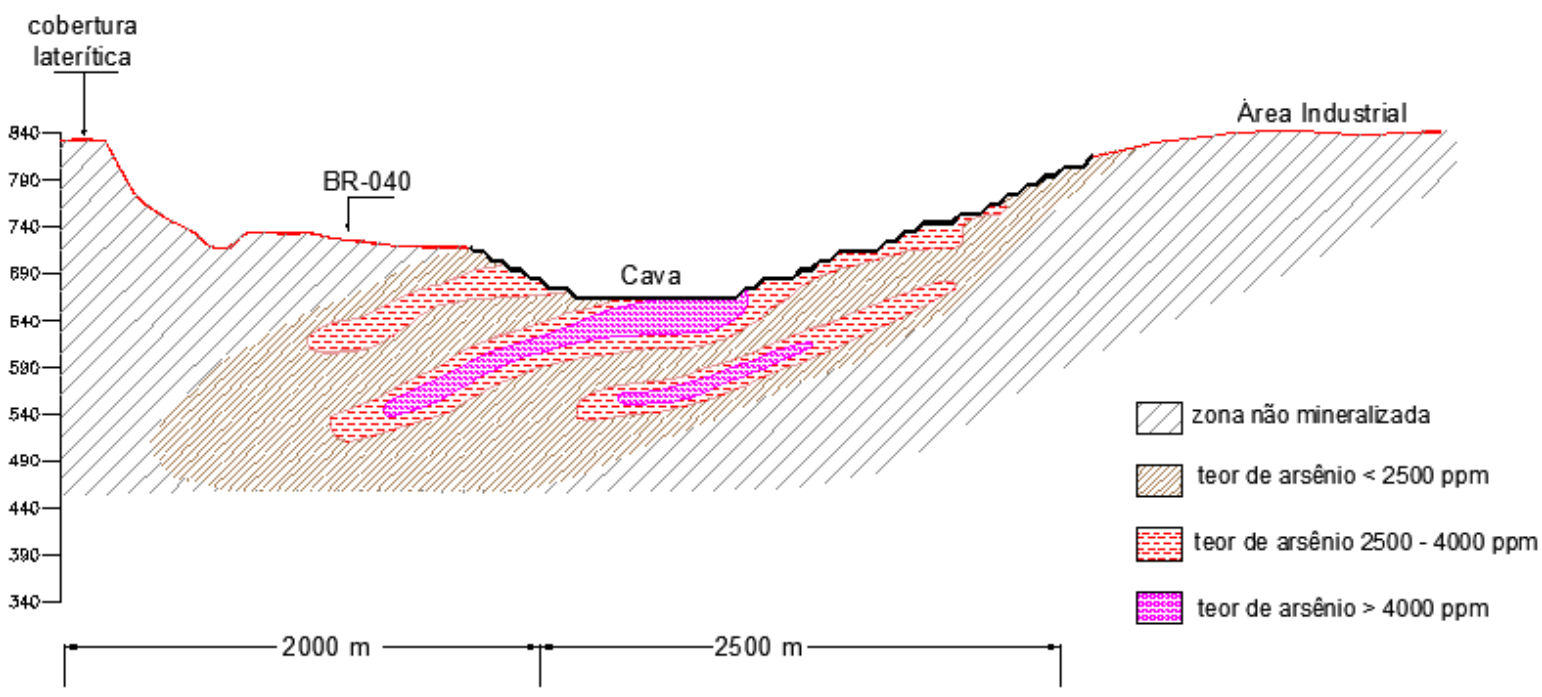

Legenda: As diferentes cores indicam os corpos de minérios em função do teor de arsênio.

\subsubsection{Lavra}

A lavra na mina Morro do Ouro é conduzida através do método convencional a céu aberto em cava (open pit). Nesse método de lavra, o material de cobertura do depósito é retirado deixando o minério exposto para ser lavrado na forma de bancadas. Para Peroni (2008), é um método que apresenta grande recuperação e pouca diluição na lavra. Sua produtividade é bastante elevada e permite a utilização de equipamentos de grande porte.

A unidade de lavra da mina é representada por blocos de $50 \mathrm{~m} \times 50 \mathrm{~m} \times 12 \mathrm{~m}$, estabelecida em função das características gerais do minério e porte dos equipamentos.

A movimentação em 2014 de minério ROM (run of mine) para usina de processamento I foi de aproximadamente $15 \mathrm{Mt} / \mathrm{a}$ mantendo ainda um estoque de $500.000 \mathrm{t}$ no período chuvoso ou indisponibilidade de lavra. Para o minério na usina de processamento II, 
a movimentação de ROM é de cerca de $45 \mathrm{Mt} / \mathrm{a}$ e é conduzida simultaneamente com minério da usina $\mathrm{I}$.

$\mathrm{Na}$ extração do minério para usina de processamento II e estéril são utilizados equipamentos de lavra de maior capacidade produtiva onde o material é $100 \%$ desmontado através de métodos controlados (espoleta eletrônica).

Pelo fato de não existir uma pilha de homogeneização, o blend do minério é feito diretamente na mina, pela lavra simultânea em duas frentes para cada usina.

Diferente da usina de processamento II, a retirada do minério oxidado beneficiado na usina I, é efetuada por desmonte mecânico por escarificação e, em áreas com rochas mais resistentes, é empregada perfuração e desmonte controlado. Atualmente, cerca de $25 \%$ da movimentação mensal é gerada por esse tipo de mecanismo.

O material destinado para a usina II alimenta um britador primário no centro da mina conectado à um transportador de correia de $1.450 \mathrm{~m}$, que movimenta o minério para uma pilha de capacidade de 400 mil toneladas que abastece o moinho SAG no início do processo produtivo da usina de processamento II.

\subsubsection{Beneficiamento mineral}

O complexo minero-metalúrgico contém, atualmente, duas unidades de processamento, denominadas usinas I e II. A distinção entre eles é devido principalmente a tenacidade do minério: a unidade de processamento I recebe minério oxidado e a unidade II, minério sulfetado com um BWI (work index de Bond) acima de $7 \mathrm{kWh} / \mathrm{t}$.

\subsubsection{Usina de processamento I}

A usina de processamento I foi a primeira a ser implantada e tem passado por alterações e ampliações desde o início da lavra em decorrência do aumento de produção e implementação de novas tecnologias para maximizar a recuperação do ouro no processo.

A Figura 2.13 apresenta o fluxograma simplificado do beneficiamento atual do minério aurífero para a usina de processamento I. 
Figura 2.13 - Fluxograma da usina de processamento I

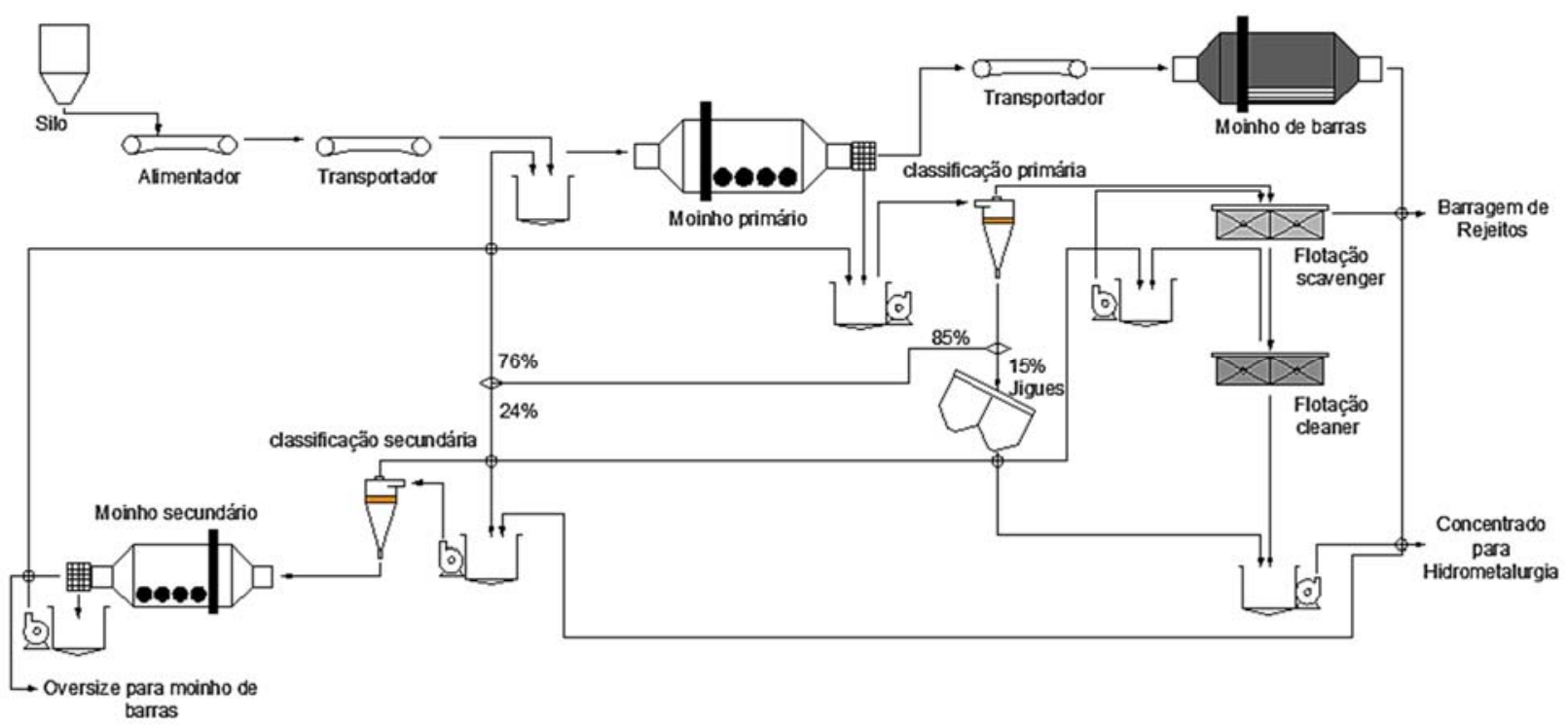

O minério proveniente da lavra passa por diversas etapas até o produto final. Essas etapas são: britagem em britador cônico com 100\% passante em 150 mm, classificação, quatro linhas paralelas de moagem a um $\mathrm{P}_{92}$ de 147 um e concentração através de hidrociclones, jigues e células de flotação. Em seguida, o concentrado produzido na fase anterior é submetido a um processo hidrometalúrgico, em que são empregados o método de lixiviação CIL (carbon in leach), eletrodeposição e fundição até chegar no produto final, o bullion de ouro.

\subsubsection{Usina de processamento II}

Atualmente, a usina II, fruto de quase 25 anos operação com a usina I, à qual foram somados o conhecimento gerado por ensaios piloto e de laboratório e um investimento de quase 570 milhões de dólares ${ }^{18}$, foi projetada para uma taxa nominal de $61 \mathrm{Mt} / \mathrm{a}$. A unidade de britagem consiste de um britador de rolos que alimenta um transportador de longa distância até a pilha de estocagem coberta. Esta estocagem é estratégica do ponto de vista de reserva de minério em caso de manutenção tanto na planta de processamento como no britador primário, conforme pode ser vista na Figura 2.14.

\footnotetext{
18 http://www.kinross.com.br/projeto_expansao.php?id_category=5
} 
Figura 2.14 - Fluxograma da usina de processamento II - Cominuição

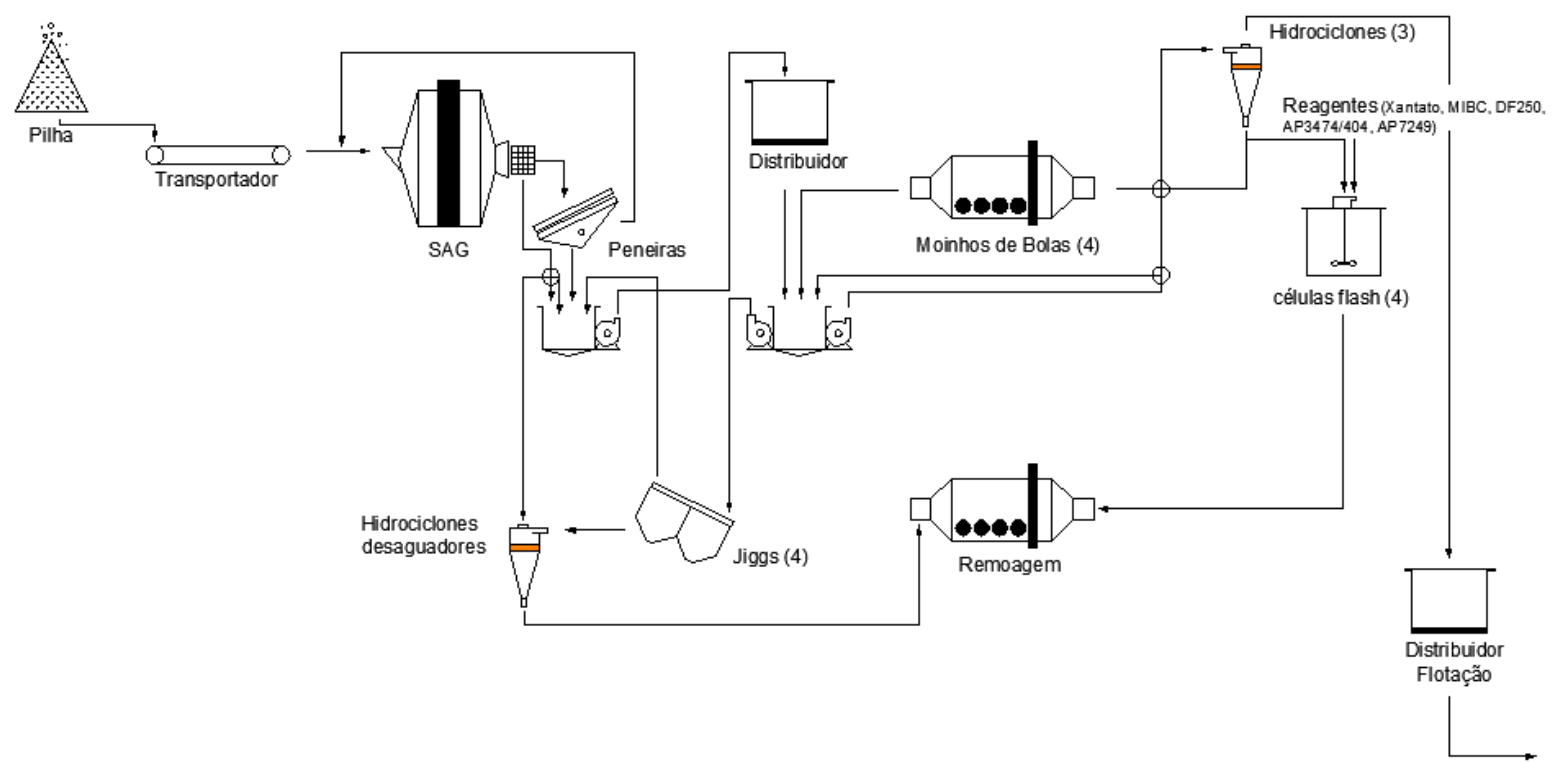

Os transportadores de correias conduzem o minério britado para a etapa de moagem composta por um moinho SAG, com carga aproximada de 10-15\% de bolas, seguido por três moinhos de bolas em paralelo processando cerca 6000 t/h, a um P80 de 105 $\mu \mathrm{m}$. Um estágio de concentração densitária usando jigues na carga circulante dos moinhos foi introduzido na tentativa de recuperação de ouro livre em uma fração mais grossa. O concentrado da jigagem, com teor médio de ouro de 25 ppm, junta-se ao concentrado da flotação para a etapa CIL.

O circuito de flotação consiste em quatro baterias com seis células rougher com hidrociclones alimentando com polpa proveniente do overflow. O concentrado da rougher é novamente flotado em duas baterias com cinco células cleaner (Figura 2.15).

O concentrado da separação densitária combinado ao concentrado da flotação é espessado antes da remoagem para remover a maior parte dos reagentes e para garantir uma densidade ótima de polpa. Os concentrados moídos são espessados novamente antes de serem bombeados para a planta de hidrometalurgia. 
Figura 2.15 - Fluxograma da usina de processamento II - Flotação

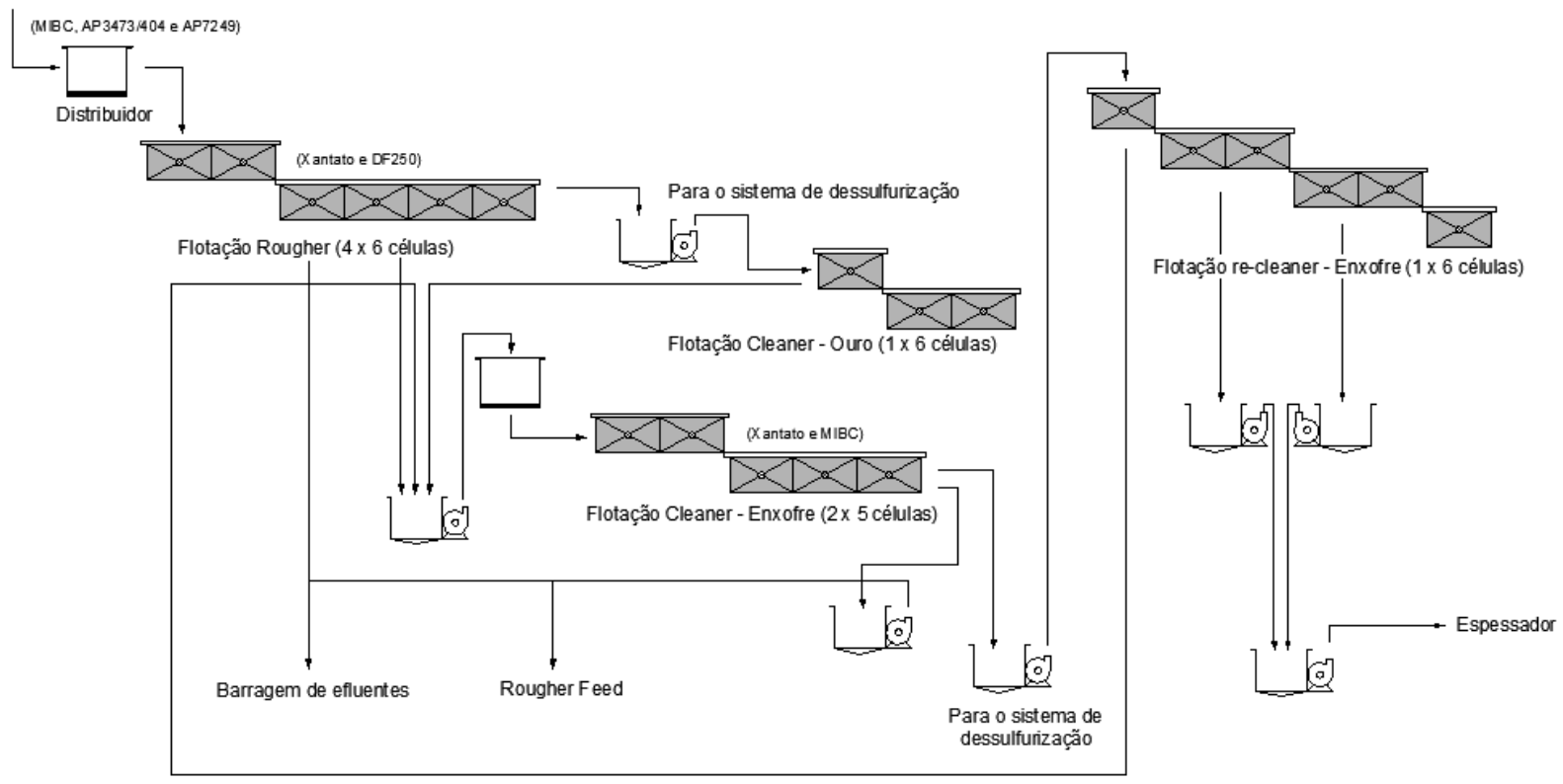

A extração de ouro dos concentrados combinados e remoídos, isto é, dos concentrados densitários e de flotação, é executada em um circuito CIL convencional (8 tanques de lixiviação CIL). A unidade CIL é precedida por um tanque de préaeração que oxida e precipita metais básicos antes da cianetação para reduzir o consumo global de cianeto. O ouro é adsorvido pelo carvão em polpa na unidade CIL. O carvão ativado é removido pelo peneiramento da polpa, sendo o ouro removido do carvão ativado por uma coluna de dessorção e seguido de eletrorecuperação. A fusão do ouro é executada usando-se fornos de indução até o produto em bullion, em uma proporção média de $75 \%$ de ouro e $25 \%$ de prata, além de impurezas como chumbo.

Por fim, o rejeito da hidrometalurgia é previamente tratado no circuito para a destruição do cianeto presente na polpa através de uma solução de metabissulfito de sódio que é adicionada a uma taxa suficiente para reduzir o cianeto livre até abaixo dos limites de detecção e também para reduzir o nível de cianocomplexos dissociáveis em ácido fraco (WAD: "weak acid dissociable cyanide")19. O cianeto dissociável em ácido fraco no reservatório deve estar em concentração inferior a 50 ppm.

\footnotetext{
${ }^{19} \mathrm{http}: / / \mathrm{www} . c y a n i d e c o d e . o r g / c y a n i d e-f a c t s / s a m p l e-a n a l y s i s$
} 


\subsubsection{Trabalhos sobre caracterização do minério do Morro do Ouro}

Os trabalhos em periódicos, dissertações e teses sobre características e variabilidade do minério do Morro do Ouro são escassos. Encontram-se trabalhos relacionados ao tratamento de minérios quanto à flotação e cominuição, geoestatística, geoquímica e gênese do depósito e relatórios técnicos ${ }^{20}$. No Quadro 2.3 encontram-se os principais trabalhos relacionados com o depósito Morro do Ouro ou regiões adjacentes.

Relatórios internos realizados por diversas consultorias, apontam para uma relação direta entre teor de ouro e distribuição de arsênio e enxofre. Estudos efetuados na UNESP - Campus Rio Claro e em laboratórios do Grupo Rio Tinto, situados na Austrália (LATTI, 1999a, 1999b) e também pela Cook University, na Austrália mostram que o ouro está intimamente associado à pirita e à arsenopirita, seja em fraturas, em meio a clusters ou inclusos em partículas livres. Apesar do trabalho ter sido realizado em apenas 3 amostras, o relatório elaborado a pedido da Rio Tinto mostrou que:

- arsenopirita é mais abundante nas porções alteradas (oxidadas) e a pirita no minério sulfetado. No presente trabalho não se verificou esse tipo de relação.

- os corpos de minério diferem em termos de distribuição de ouro: zonas oxidadas contém mais ouro grosso liberado e ultrafino com significativa inclusão em gangas. Ouro em zonas sulfetadas associam-se predominantemente aos sulfetos.

- perda de ouro no processo ocorre em ouro ultrafino e associados às gangas, principalmente silicatos. Recuperação da fração $+0,020 \mathrm{~mm}$ de ouro livre e associado a sulfetos pode ser baixo para um rejeito de $0.08 \mathrm{ppm}$ ainda mais na fração $-0,020 \mathrm{~mm}$ um com 0,03 ppm de ouro.

- ocorrência de ouro associados aos sulfetos em solução sólida: pirita contém baixa concentração de ouro em solução sólida.

\footnotetext{
${ }^{20}$ http://www.kinross.com/pdf/operations/Technical-Report-Paracatu.pdf
} 
Quadro 2.3 - Principais trabalhos relacionados ao depósito Morro do Ouro

\begin{tabular}{|c|c|c|c|c|}
\hline Ano & Tema & Titulo & Autor & Publicado em: \\
\hline 1991 & $\begin{array}{l}\text { geologia } \\
\text { estrutural }\end{array}$ & $\begin{array}{l}\text { Enquadramento litoestratigráfico e } \\
\text { estrutural do depósito de ouro do Morro } \\
\text { do Ouro }\end{array}$ & $\begin{array}{l}\text { FREITAS-SILVA, } \\
\text { F.H. }\end{array}$ & $\begin{array}{l}\text { Dissertação de } \\
\text { mestrado - UnB }\end{array}$ \\
\hline 1991 & $\begin{array}{l}\text { geologia } \\
\text { estrutural }\end{array}$ & $\begin{array}{l}\text { Controles litoestruturais do depósito de } \\
\text { ouro do Morro do Ouro }\end{array}$ & $\begin{array}{l}\text { FREITAS-SILVA, } \\
\text { F.H. et al. }\end{array}$ & $\begin{array}{l}6^{\circ} \text { Simpósio de } \\
\text { geologia de Minas } \\
\text { Gerais }\end{array}$ \\
\hline 1993 & $\begin{array}{l}\text { sensoriamento } \\
\text { remoto }\end{array}$ & $\begin{array}{l}\text { O comportamento espectral e } \\
\text { radiométrico dos filitos carbonosos } \\
\text { portadores de mineralizações auríferas } \\
\text { na Faixa Brasília }\end{array}$ & $\begin{array}{l}\text { MENESES, P. R. } \\
\text { et al. }\end{array}$ & $\begin{array}{l}\text { Anais do VII } \\
\text { SBSR }\end{array}$ \\
\hline 1996 & metalogênese & $\begin{array}{l}\text { Geologia, mineralização e lavra do } \\
\text { Morro do Ouro - Paracatu (MG) }\end{array}$ & MARQUES, F.B & $\begin{array}{l}\text { Congresso } \\
\text { Brasileiro de } \\
\text { Geologia }\end{array}$ \\
\hline 1996 & metalogênese & $\begin{array}{l}\text { New ideas regarding the origin and } \\
\text { tectonic setting of mineral deposits } \\
\text { (Morro Agudo } \mathrm{Zn}-\mathrm{Pb} \text { and Morro do Ouro } \\
\mathrm{Au} \text { ) in the Paracatu-Vazante fold belt, } \\
\text { Minas Gerais }\end{array}$ & THORMAN, C.H & $\begin{array}{l}\text { Congresso } \\
\text { Brasileiro de } \\
\text { Geologia }\end{array}$ \\
\hline 1996 & metalogênese & $\begin{array}{l}\text { Metalogênese do depósito Morro do } \\
\text { Ouro }\end{array}$ & $\begin{array}{l}\text { FREITAS-SILVA, } \\
\text { F.H. }\end{array}$ & $\begin{array}{l}\text { Congresso } \\
\text { Brasileiro de } \\
\text { Geologia - } \\
\text { Salvador }\end{array}$ \\
\hline 1996 & metalogênese & $\begin{array}{l}\text { Metalogênese do depósito Morro do } \\
\text { Ouro }\end{array}$ & $\begin{array}{l}\text { FREITAS-SILVA, } \\
\text { F.H. }\end{array}$ & $\begin{array}{l}\text { Tese de } \\
\text { doutorado }\end{array}$ \\
\hline 1998 & metalogênese & $\begin{array}{l}\text { An overview of main auriferous regions } \\
\text { of brazil }\end{array}$ & MARTINI, S. L. & $\begin{array}{l}\text { Revista Brasileira } \\
\text { de Geociências }\end{array}$ \\
\hline 2001 & metalogenese & $\begin{array}{l}\text { Geologia e recursos minerais do } \\
\text { depósito Morro do Ouro }\end{array}$ & $\begin{array}{l}\text { MOLLER, J. C. et } \\
\text { al. }\end{array}$ & $\begin{array}{l}\text { Bacia do São } \\
\text { Francisco - SBG }\end{array}$ \\
\hline 2000 & petrografia & $\begin{array}{l}\text { Estudo petrográfico e mineralógico de } \\
\text { rochas na Mina Morro do Ouro. }\end{array}$ & DAITX et al. & Trabalho técnico \\
\hline 2000 & $\begin{array}{l}\text { sensoriamento } \\
\text { remoto }\end{array}$ & $\begin{array}{l}\text { Modelo exploratório para depósitos } \\
\text { auríferos do tipo Morro do Ouro com } \\
\text { base em dados e técnicas de } \\
\text { sensoriamento remoto }\end{array}$ & SWALF, P.S. & $\begin{array}{l}\text { Dissertação de } \\
\text { mestrado - } \\
\text { Unicamp }\end{array}$ \\
\hline 2001 & geoestatística & $\begin{array}{l}\text { Modelagem geológica e estocástica da } \\
\text { porção NE da Mina de Morro do Ouro, } \\
\text { Paracatu. }\end{array}$ & SILVA, A. H. M. & $\begin{array}{l}\text { Dissertação de } \\
\text { mestrado - } \\
\text { Unicamp }\end{array}$ \\
\hline 2002 & flotação & Ouro - Rio Paracatu Mineração - RPM & $\begin{array}{l}\text { MELLO MONTE, } \\
\text { M. B. }\end{array}$ & CETEM \\
\hline 2003 & $\begin{array}{l}\text { sensoriamento } \\
\text { remoto }\end{array}$ & $\begin{array}{l}\text { Remote sensing signature of the Morro } \\
\text { do Ouro gold deposit, Minas Gerais, } \\
\text { Brazil, using reflectance spectrometry: } \\
\text { application to mineral exploration using } \\
\text { spaceborne multispectral sensors }\end{array}$ & SWALF, P.S. & $\begin{array}{l}\text { Revista Brasileira } \\
\text { de Geociências }\end{array}$ \\
\hline 2006 & hidrogeologia & $\begin{array}{l}\text { Estudos hidrogeológicos na mina Morro } \\
\text { do Ouro }\end{array}$ & CHAPADEIRO, E. & XIV CBAS \\
\hline 2009 & geoquímica & $\begin{array}{l}\text { Gênese de depósitos dos filitos } \\
\text { carbonosos do depósito Morro do Ouro }\end{array}$ & ALMEIRA, B.S. & $\begin{array}{l}\text { Dissertação de } \\
\text { mestrado - UnB }\end{array}$ \\
\hline 2011 & flotação & $\begin{array}{l}\text { Desenvolvimento de uma rota de } \\
\text { processo de dessulfurização de rejeitos } \\
\text { de um minério aurífero sulfetado }\end{array}$ & JUNIOR, G.G.O. & $\begin{array}{l}\text { Dissertação de } \\
\text { mestrado - UFMG }\end{array}$ \\
\hline
\end{tabular}




\begin{tabular}{|c|c|c|c|c|}
\hline Ano & Tema & Titulo & Autor & Publicado em: \\
\hline 2012 & moagem & $\begin{array}{l}\text { Moagem Semiautógena piloto do } \\
\text { minério de ouro da Rio Paracatu } \\
\text { Mineração }\end{array}$ & SILVA, A.L. & $\begin{array}{l}\text { Dissertação de } \\
\text { mestrado - USP }\end{array}$ \\
\hline 2013 & geometalurgia & $\begin{array}{l}\text { Morro do Ouro geological model with a } \\
\text { metallurgical view }\end{array}$ & ESPER, E. & $\begin{array}{l}\text { GeoMet - } \\
\text { AUSIMM } \\
\text { Conference }\end{array}$ \\
\hline 2015 & metalogênese & $\begin{array}{l}\text { Local and regional mass tranfer during } \\
\text { thrusting, veining and boudinage in the } \\
\text { genesis of the giant shale-hosted } \\
\text { Paracatu Gold Deposit, Minas Gerais, } \\
\text { Brazil }\end{array}$ & OLIVER, N.H.S. & $\begin{array}{l}\text { Economic } \\
\text { Geology }\end{array}$ \\
\hline
\end{tabular}

Obs: Organizado por ano de publicação.

Segundo relatório realizado pela Blue Coast em 2010, o minério sulfetado apresenta como principais características (BLUE COAST METTALURGY, 2010):

- $74 \%$ de liberação de ouro com grãos de ouro acima de $10 \mu \mathrm{m}$ passíveis de serem totalmente recuperadas. 35\% das partículas liberadas são abaixo de 10 $\mu \mathrm{m}$ e não são recuperadas por processos de flotação.

- $\quad$ no geral, as partículas liberadas têm recuperação média de $86 \%$ na flotação.

- até $8 \%$ não será recuperada pois estão em "solução sólida" com arsenopirita e pirita.

- recuperação global no circuito de flotação é de aproximadamente $78 \%$.

Ainda em 2010, um outro estudo a respeito da perda de ouro para o rejeito foi realizado pela AMTEL na qual foi constatado a perda de ouro no circuito de lixiviação pelo fenômeno de preg-robbing, além presença de ouro submicroscópico associado à pirita e arsenopirita (11\% de ouro residual de sulfeto no circuito de finos) (AMTEL, 2010).

A partir de 2013, dentro de um programa estratégico de longo prazo, iniciou-se uma série de trabalhos de geometalurgia com o intuito agregar conhecimento e melhorar a previsão de desempenho do minério nas usinas de processamento. 


\section{MATERIAIS E MÉTODOS}

\subsection{MATERIAIS}

As amostras utilizadas fazem parte de um plano de trabalho denominado "Estudos mineralógicos quantitativos por MEV/MLA" na qual foram selecionadas amostras pontuais em escala de lavra de acordo com o plano anual de lavra dos anos de 2015 e 2016.

As amostras estudadas, cada qual com cerca de $5 \mathrm{~kg}$ foram compostas a partir de um intervalo selecionado de 1 metro de testemunhos de sondagem. A Figura 3.1 ilustra a amostragem nos testemunhos de sondagem (em vermelho).

Figura 3.1 - Amostragem de testemunho de sondagem

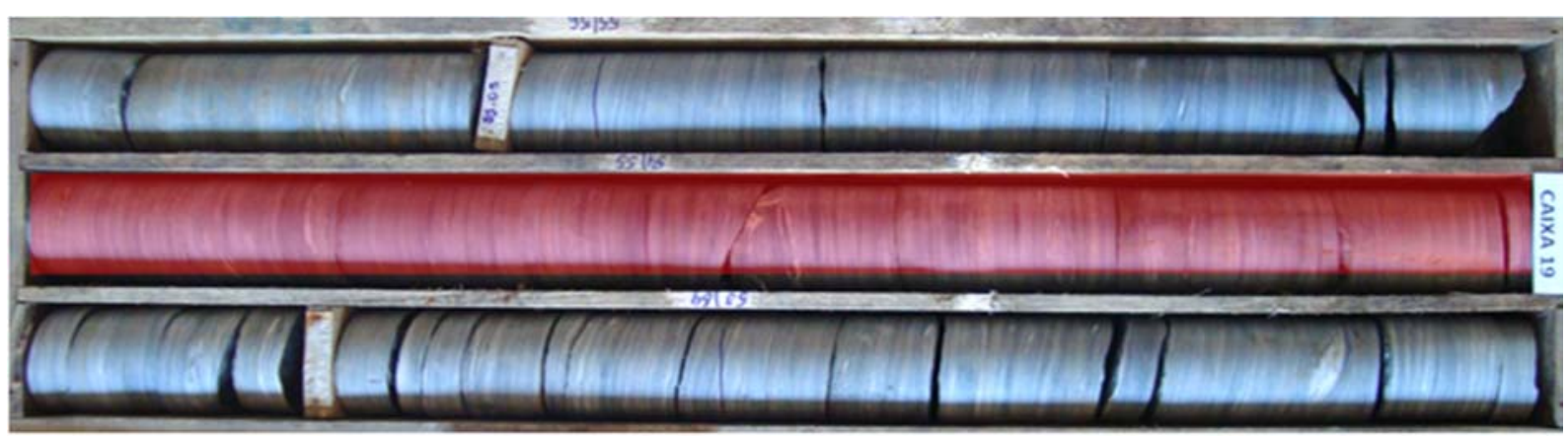

Legenda em vermelho, intervalo amostrado de 1 metro.

As amostras referentes à frente de lavra (fragmentos) foram coletadas em intervalos de aproximadamente 15 centímetros, espaçados de metro a metro, ao longo de uma canaleta em um banco de 12 metros de altura e, posteriormente, agrupadas em um lote respeitando os limites do intervalo do corpo mineralizado. A Figura 3.2 ilustra a metodologia aplicada para a coleta de amostra na frente de lavra. 
Figura 3.2 - Amostragem na de frente de lavra

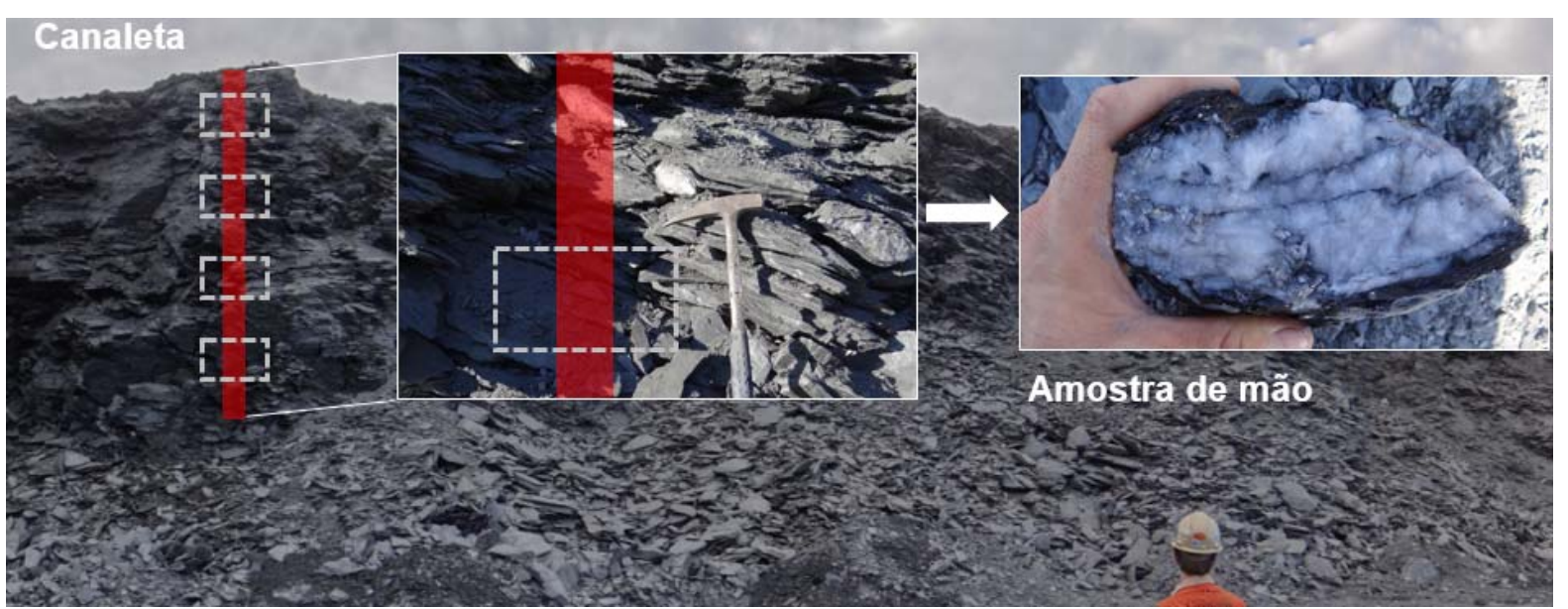

Legenda: áreas demarcadas pelas linhas tracejadas brancas: local de coleta.

\subsection{PROCEDIMENTOS ADOTADOS}

As amostras foram britadas abaixo de 2,36 $\mathrm{mm}$ nas instalações da Kinross e posteriormente amostradas e enviadas para o Laboratório de Caracterização Tecnológica - LCT, do Departamento de Engenharia de Minas e de Petróleo da Escola Politécnica da USP.

Os estudos de caracterização foram realizados de acordo com o procedimento experimental apresentado na Figura 3.3 e detalhado nos itens a seguir.

A primeira etapa envolveu cominuição em britador de rolos abaixo de $0,50 \mathrm{~mm}$ da amostra total $(5 \mathrm{~kg})$ e retirada de duas alíquotas de 500 gramas em amostrador Jones, sendo uma alíquota para o peneiramento a úmido e a outra para análise de difração e análise mineralógica por MLA.

A segunda etapa compreendeu o peneiramento a úmido $(-0,50+0,020 \mathrm{~mm})$ e nova amostragem das alíquotas para ensaio de separação mineral por líquidos densos.

Na terceira e última etapa, apenas o produto afundado resultante das separações em líquidos densos foi amostrado para confecção de seções polidas e execução de estudos de caracterização mineralógica. Todos os procedimentos estão detalhados a seguir. 
Figura 3.3 - Fluxograma das atividades realizadas

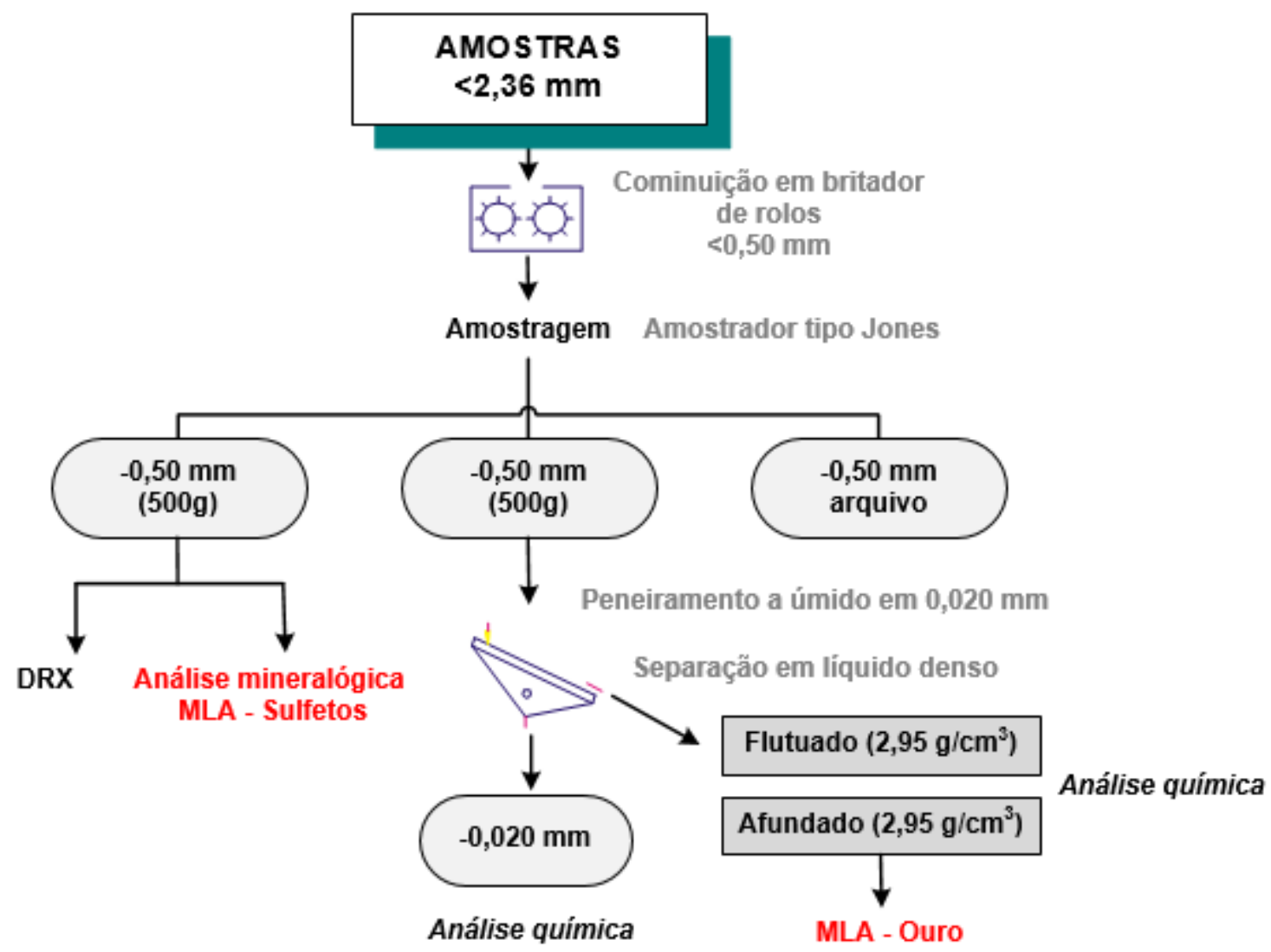

3.2.1 Cominuição e homogeneização

As amostras provenientes da amostragem em testemunho e frente de lavra com granulometria inferior a 2,36 mm passaram por uma operação de fragmentação em escala de laboratório utilizando britador de rolos em circuito fechado com peneira de $0,50 \mathrm{~mm}$ de abertura (Figura 3.4). 
Figura 3.4 - Aspecto geral das amostras estudadas - amostra tal qual

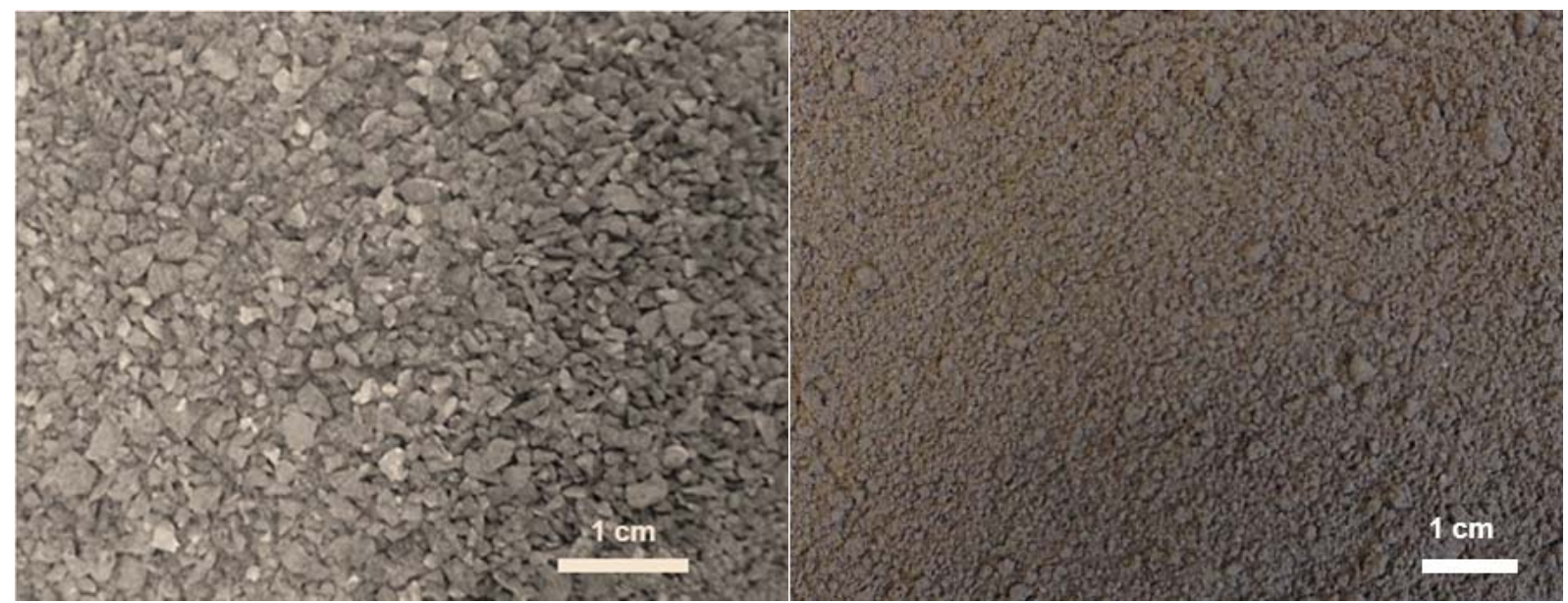

Amostra abaixo de $2,36 \mathrm{~mm}$

Amostra abaixo de $0,50 \mathrm{~mm}$

A divisão da amostra e homogeneização foram realizadas em divisor Jones (16 calhas totais) e retiradas duas alíquotas de $1 / 8$ do total (cerca de $500 \mathrm{~g}$ cada) para as etapas de preparação e análise (Figura 3.5). O restante do material, perfazendo cerca de 4,0 $\mathrm{kg}$, foram armazenadas nas dependências no LCT.

Figura 3.5 - Equipamentos utilizados para cominuição e divisão da amostra

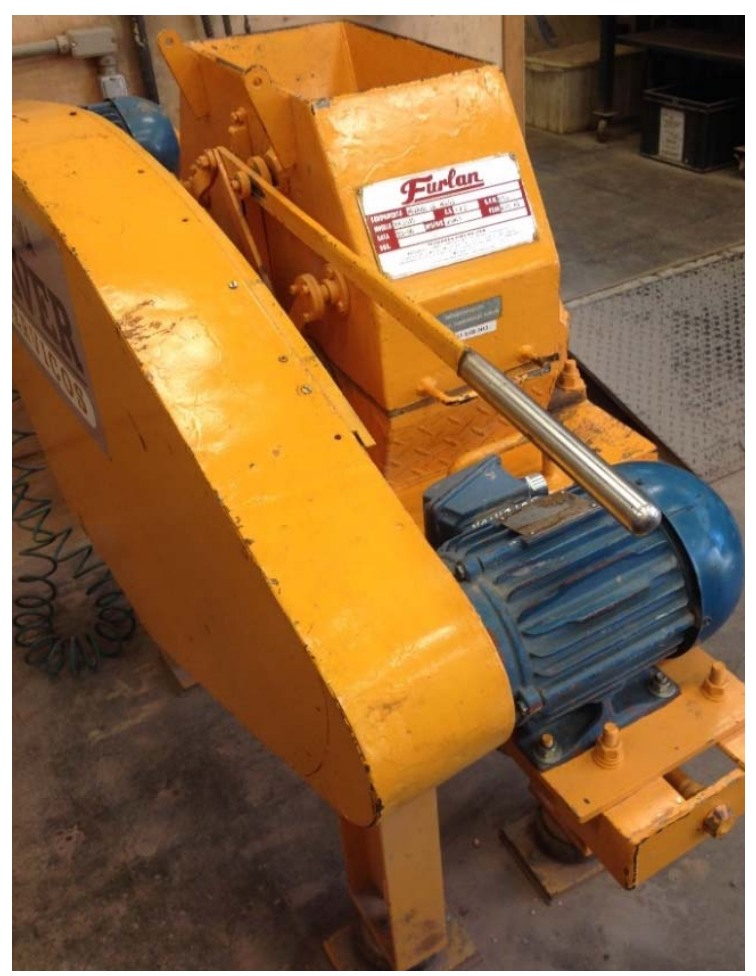

Britador de rolos

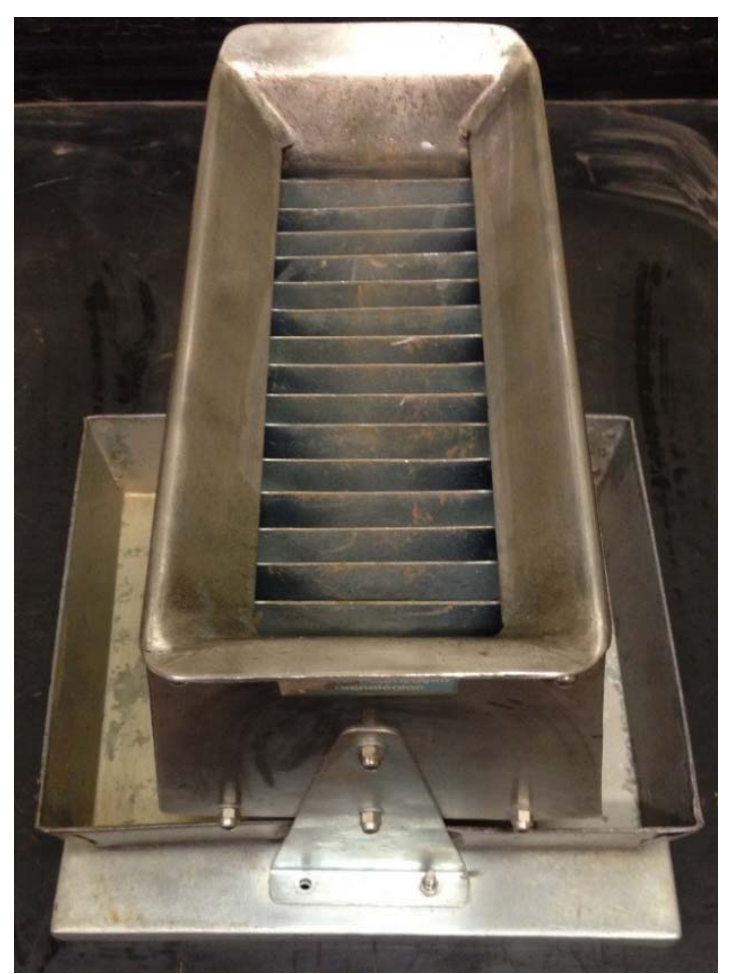

Amostrador Jones 


\subsubsection{Peneiramento e deslamagem}

Após a etapa de cominuição e subdivisão (amostragem), as amostras uma alíquota $(500 \mathrm{~g})$ foi submetida ao peneiramento a úmido sob lavagem intensa em peneira com abertura de $0,020 \mathrm{~mm}$ (Figura 3.6). A fração retida acima de $0,020 \mathrm{~mm}$ foi objeto de separações minerais em líquidos densos e de preparação de seções polidas; já a fração passante em $0,020 \mathrm{~mm}$ foi seca, amostrada e enviada para análise química multielementar por fluorescência de raios $X$ (sem padrões), ouro, arsênio e enxofre em laboratório externo. A caracterização tecnológica do ouro e sulfetos foram realizados somente na fração retida acima de $0,020 \mathrm{~mm}$.

Figura 3.6 - Peneirador Haver EML 450 utilizado no peneiramento a úmido

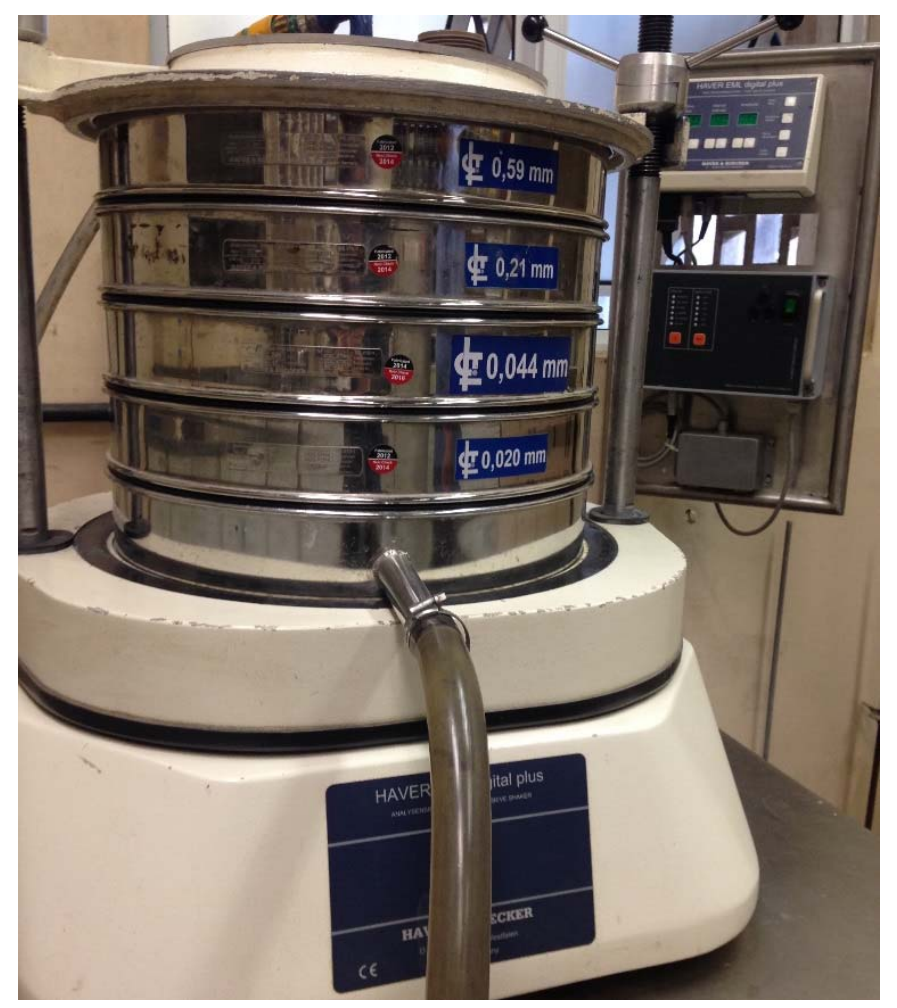

Legenda: Peneiramento em $+0,020 \mathrm{~mm}$. Foi utilizado um conjunto de peneiras acima de $0,020 \mathrm{~mm}$ para melhorar a eficiência no procedimento.

\subsubsection{Separações minerais em líquidos densos}

As separações minerais por líquidos densos da fração retida acima de 0,020 mm objetivaram a concentração de fases minerais com base nas suas densidades. Para o minério estudado, há uma diferença significativa de densidade entre a ganga, 
composta essencialmente por silicatos, e os sulfetos e ouro. A Tabela 3.1 mostra as densidades dos minerais presentes no minério do depósito Morro do Ouro.

O produto afundado foi amostrado para confecção de seções polidas visando caracterizar a forma de ocorrência e associações dos grãos de ouro. Adicionalmente, todos os produtos flutuados e afundados obtidos foram enviados para análise química (Au: Fire assay; S: pirólise em forno de indução e ICP-OES para As) em laboratório externo.

Tabela 3.1 - Composição e densidade dos principais minerais presentes no depósito Morro do Ouro

\begin{tabular}{|c|c|c|}
\hline Mineral & Fórmula ${ }^{21}$ & Densidade $\left(\mathrm{g} / \mathrm{cm}^{3}\right)$ \\
\hline clorita & $(\mathrm{Mg}, \mathrm{Al}, \mathrm{Fe})_{12}(\mathrm{Si}, \mathrm{Al})_{8} \mathrm{O}_{20}(\mathrm{OH})_{16}$ & 2,61 \\
\hline albita & $\mathrm{NaAISi}_{3} \mathrm{O}_{8}$ & 2,63 \\
\hline quartzo & $\mathrm{SiO}_{2}$ & 2,65 \\
\hline mica & $\mathrm{KNaAIMgFe}_{2} \mathrm{Si}_{3} \mathrm{AlO}_{10}(\mathrm{OH}, \mathrm{F})_{2}$ & 2,76 \\
\hline anquerita & $\mathrm{Ca}\left(\mathrm{Fe}^{2+}, \mathrm{Mg}, \mathrm{Mn}\right)\left(\mathrm{CO}_{3}\right)_{2}$ & 3,12 \\
\hline siderita & $\mathrm{FeCO}_{3}$ & 3,70 \\
\hline goethita & $\alpha-\mathrm{FeO}(\mathrm{OH})$ & 3,80 \\
\hline esfalerita & $\mathrm{ZnS}$ & 3,90 \\
\hline calcopirita & $\mathrm{CuFeS}_{2}$ & 4,10 \\
\hline pirrotita & $\mathrm{Fe}_{1-\mathrm{xS}}$ & 4,58 \\
\hline pirita & $\mathrm{FeS}_{2}$ & 5,02 \\
\hline arsenopirita & FeAsS & 6,07 \\
\hline galena & $\mathrm{PbS}$ & 7,40 \\
\hline ouro & $\mathrm{Au}, \mathrm{Ag}$ & 19,3 \\
\hline
\end{tabular}

As separações foram efetuadas com o emprego de tetra-bromo-etano $\left(2,96 \mathrm{~g} / \mathrm{cm}^{3}\right) \mathrm{em}$ centrífuga da marca Novatecnica NT 820. As condições operacionais foram: 2 operações sequenciais de 5 minutos cada, a uma rotação de 900 RPM. A Figura 3.7 mostra o equipamento utilizado e o processo de separação em líquido denso.

${ }^{21}$ Fórmulas e densidades em: http://webmineral.com/ 
Figura 3.7 - Procedimento de separação por líquidos densos e equipamento
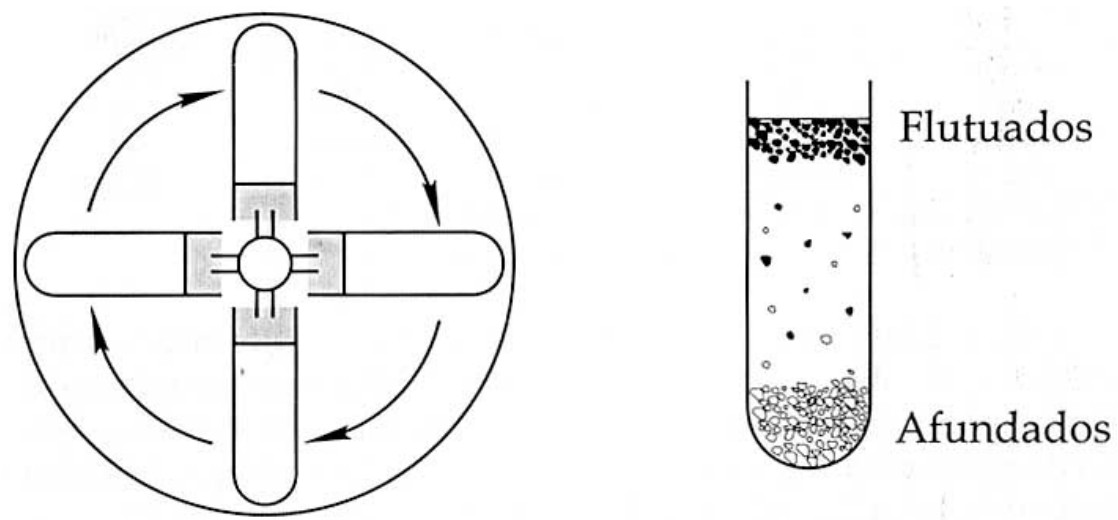

Fonte: adaptado de SAMPAIO et al., (2005)

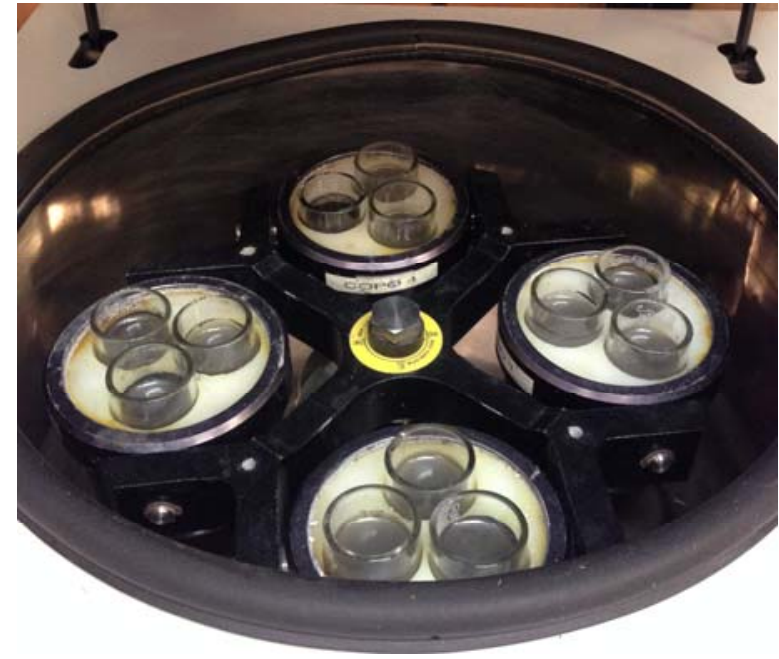

Centrifuga com 4 suportes

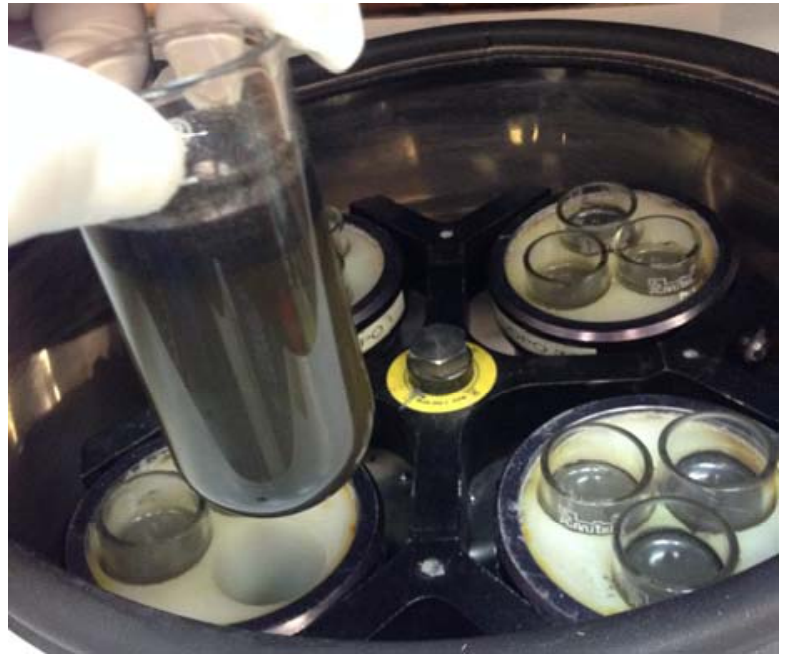

Tubo com material separado

3.2.4 Difração de raios $X$ e análises químicas

A alíquota resultante $(500 \mathrm{~g})$ da separação da amostra total $(5 \mathrm{~kg})$ foi selecionada para a análise de difração de raios $\mathrm{X}$ e analise mineralógica por MLA. Para a análise de difração de raios $\mathrm{X}$, as amostras foram cominuídas em moinho de disco e quarteadas até atingir aproximadamente $30 \mathrm{~g}$. Contraparte das amostras assim processadas, com massa de 100 a $200 \mathrm{~g}$ foram objeto de análises químicas por fluorescência de raios $\mathrm{X}$.

Tais alíquotas foram pulverizadas em moinho planetário Pulverizette 5, marca Fritsch, de forma a se ter granulação inferior a $37 \mu \mathrm{m}$, seguido de prensagem manual em suportes específicos para material em pó (Figura 3.8). 
As análises difratométricas foram realizadas em equipamento X'Pert Pro, marca PANalytical com tubo de Cu e detector sensível à posição (PSD - X'Celerator). As condições de coleta empregadas são apresentadas no Quadro 3.1. A identificação das fases cristalinas foi obtida por comparação do difratograma da amostra com os bancos de dados PDF2 do ICDD - International Centre for Diffraction Data (2003) e PAN-ICSD - PANalytical Inorganic Crystal Structure Database (2007).

Quadro 3.1 - Condição de coleta dos difratogramas

\begin{tabular}{ll}
\hline Radiação & $\mathrm{Cu} \mathrm{K}(\lambda=1,54186 \AA)$ \\
Energia no tubo (voltagem x corrente) & $45 \mathrm{kV} \times 40 \mathrm{~mA}$ \\
Faixa angular $\left({ }^{\circ} 2 \theta\right)$ & 2,5 a $70^{\circ}$ \\
Passo angular $\left({ }^{\circ} 2 \theta\right)$ & $0,02^{\circ}$ \\
Tempo de coleta por passo & $25 \mathrm{~s}$ \\
Tempo total de coleta & 13 min por amostra \\
\hline
\end{tabular}

Figura 3.8 - Equipamentos utilizados para difração de raios $X$

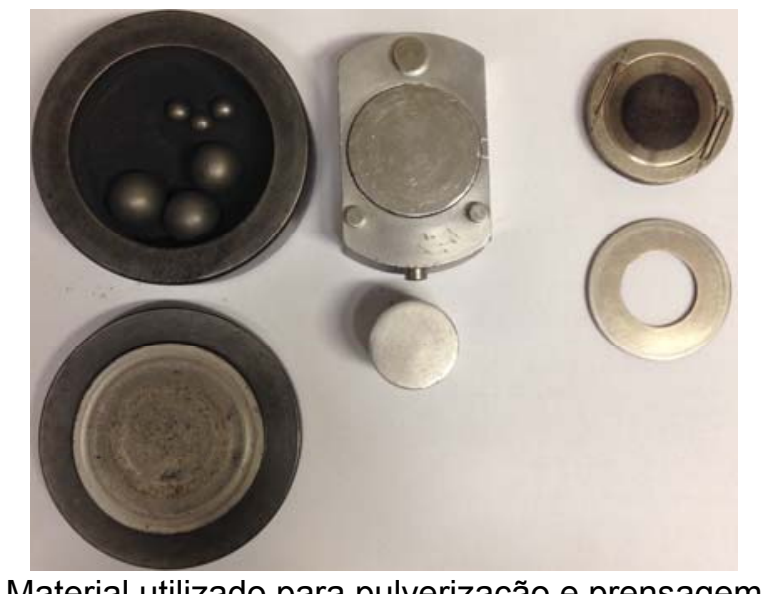

Material utilizado para pulverização e prensagem manual

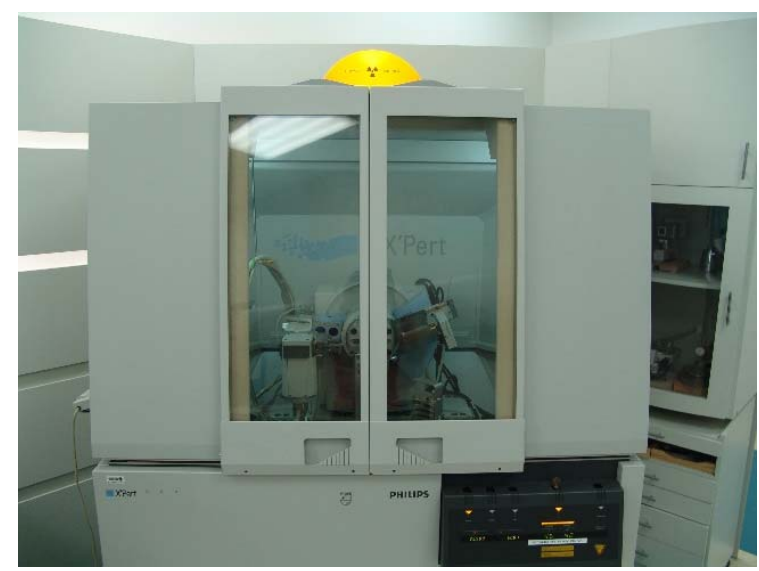

Difratômetro de raios X - X'Pert Pro, marca PANalytical

As análises químicas foram efetuadas em contraparte das amostras objeto de análise por difração de raios $X$. As amostras foram pulverizadas em moinho de panelas HSM250 P, marca Herzog, seguido de amostragem em amostrador rotativo.

Uma alíquota foi analisada por espectrometria de fluorescência de raios $X$ com determinação sem padrões para elementos de $F$ ao $U$ em equipamento Axios Advanced, marca PANalytical; perda ao fogo foi efetuada em temperatura de $1050^{\circ} \mathrm{C}$ por $1 \mathrm{~h} 30 \mathrm{~min}$. As análises de Au, S e As foram realizadas em laboratório externo sendo 
utilizadas as técnicas de fire assay para determinação de ouro, pirólise em forno de indução para enxofre e ICP-OES para As.

Além das amostras tal qual, todos os demais produtos gerados no estudo também foram objeto de determinações de Au, S e As.

\subsection{CARACTERIZAÇÃO MINERALÓGICA E ASSOCIAÇÕES}

A caracterização mineralógica das amostras estudadas e a forma de ocorrência e associações de sulfetos foi efetuada a partir de alíquota do material bulk; já o estudo da forma de ocorrência do ouro e suas associações foi realizada a partir dos produtos afundados em líquidos densos $\left(\mathrm{d}>2,96 \mathrm{~g} / \mathrm{cm}^{3}\right)$.

Em ambas as situações, os produtos acima citados foram amostrados em microamostrador rotativo (Microscal MSR) que possui 20 calhas (Figura 3.9). A depender da massa necessária para a confecção das seções polidas, a amostragem foi realizada coletando a quantidade de calhas ( 1 calha $=1 / 20$ da massa inicial) até se atingir a massa adequada.

Figura 3.9 - Equipamentos utilizados para divisão da amostra
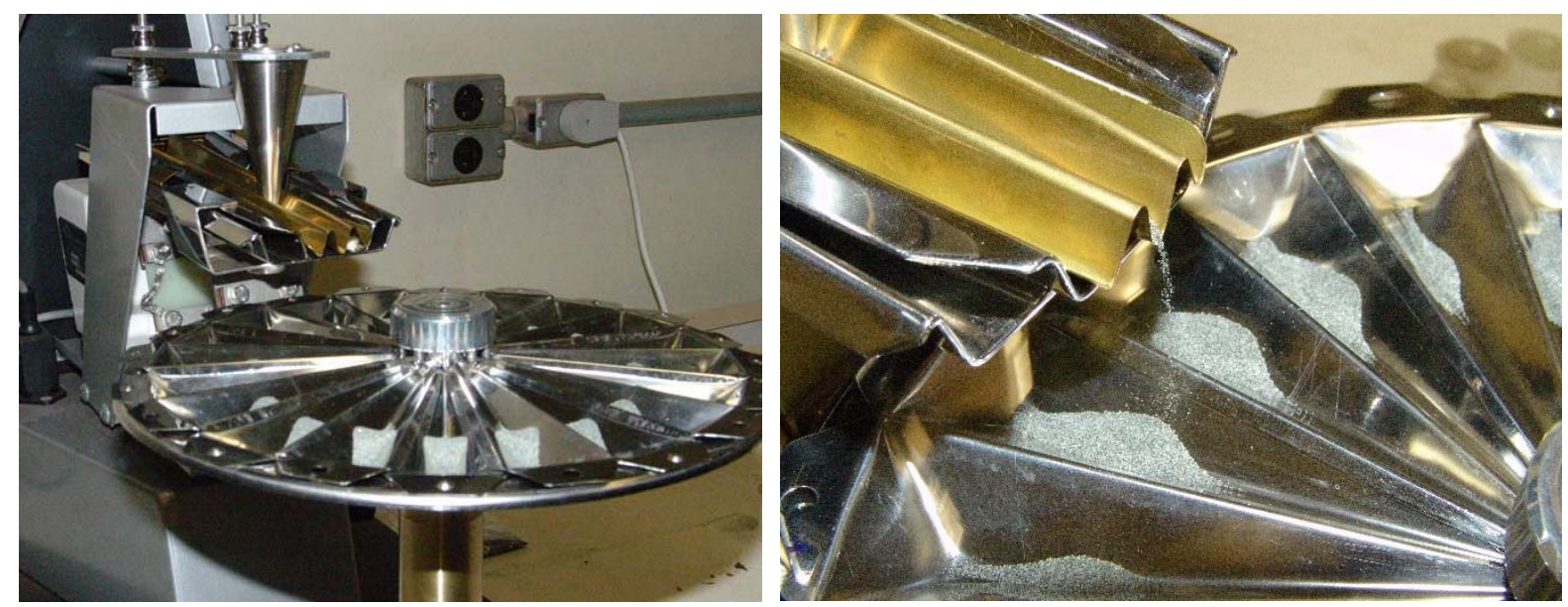

Após a amostragem, foram confeccionadas seções polidas para análise da mineralogia e seções para os produtos afundados em liquido denso (-0,50+0,02 mm). Para a análise mineralógica foram confeccionadas seções polidas do tipo transversal e para o estudo do ouro, seção convencional centrifugada. Foram confeccionadas pelo menos 3 seções polidas para ambos os tipos de seções. Detalhe dos tipos de 
seções polidas e os procedimentos empregados para a preparação das mesmas são apresentados por Carmo (2015).

Os estudos mineralógicos foram efetuados de forma automatizada em seções polidas utilizando software MLA - Mineral Liberation Analyser (FEI) acoplado ao microscópio eletrônico de varredura Quanta 600 FEG (FEI) e espectrômetro por dispersão de energia (EDS) Quantax 4030 com software Esprit (Bruker).

Os procedimentos da análise mineralógica quantitativa utilizando o programa MLA podem ser resumidos nas etapas apresentadas na Figura 3.10.

Figura 3.10 - Procedimento de coleta e processamento dos dados - MLA

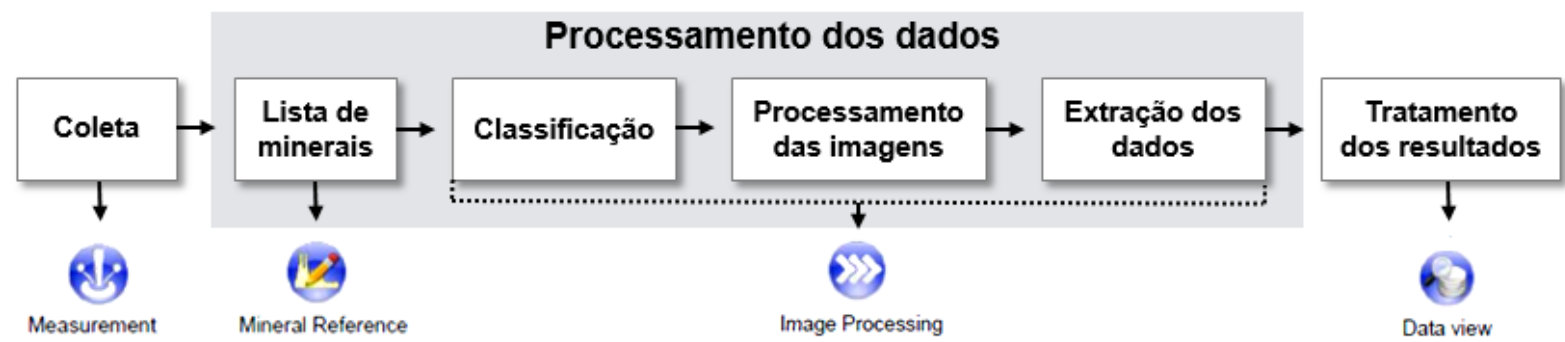

Obs: Procedimento adotado da aquisição dos dados até o tratamento dos resultados. Os softwares (measurement, mineral reference, image processing e data view) dizem respeito ao pacote de utilidades especifico para cada atividade. Adaptado de CARMO, (2015).

A determinação da composição mineralógica, forma de ocorrência e associações dos sulfetos foi efetuada em seções transversais a partir de coleta em modo XBSE que considera contraste de número atômico (imagens de elétrons retroespalhados) e espectros de raios $X$ característico (EDS).

Já a determinação da forma de ocorrência e associações minerais do ouro nos produtos pesados foi realizada a partir do modo SPL, que considera a identificação inicial dos grãos de ouro por contraste de número atômico (elétrons retroespalhados) e espectro de EDS. Uma vez localizado um grão de ouro podem ser identificadas as fases associadas ao mesmo (perímetro de contato).

A busca automatizada dos grãos de ouro foi efetuada a de partir seções polidas de 30 $\mathrm{mm}$ de diâmetro relativas ao produto afundado com um tempo de análise aproximado de 2,5h/seção nas condições de aumento de 300X e 1200 pixels de resolução/campo. 
Um banco de dados específico para o presente estudo, contendo dados de peso específico, composição química e espectro de EDS, foi criado para todos os minerais presentes (mineral reference). Posteriormente, os dados coletados nas análises ao MLA foram comparados com este banco de dados para a classificação dos minerais em cada seção polida.

\subsection{CÁLCULO DAS ASSOCIAÇÕES DOS GRÃOS DE OURO EM PERÍMETRO DE CONTATO}

Como mencionado anteriormente, o processo de separação mineral em líquido denso faz-se necessário para auxiliar na concentração de minerais de interesse dos minerais de minérios já liberados para os processos de extração por lixiviação.

No caso de minerais de minério de ouro, o termo acessibilidade é mais adequado pois o grão de ouro não necessita necessariamente estar liberado, mas parcialmente exposto para ser acessado por uma solução lixiviante através da fratura. A extração de ouro por uma solução de cianeto pode ocorrer através dessa fratura ou algum outro meio que propicia o acesso e a lixiviação do grão de ouro.

A Tabela 3.2 apresenta um exemplo dos parâmetros determinados para cada grão de ouro e a sua respectiva associação com base nos seus perímetros de contato.

Em um processo de extração mineral é clara a importância da quantificação do perímetro exposto do ouro, a sua relação com grãos inclusos e a sua associação com os minerais (sulfetos, silicatos, etc). A parcela do perímetro exposto é diretamente proporcional à capacidade de extração do ouro por uma solução de cianeto. 
Tabela 3.2 - Propriedades dos grãos de ouro a partir do perímetro de contato (modelo de extração dos dados do MLA - grain properties)

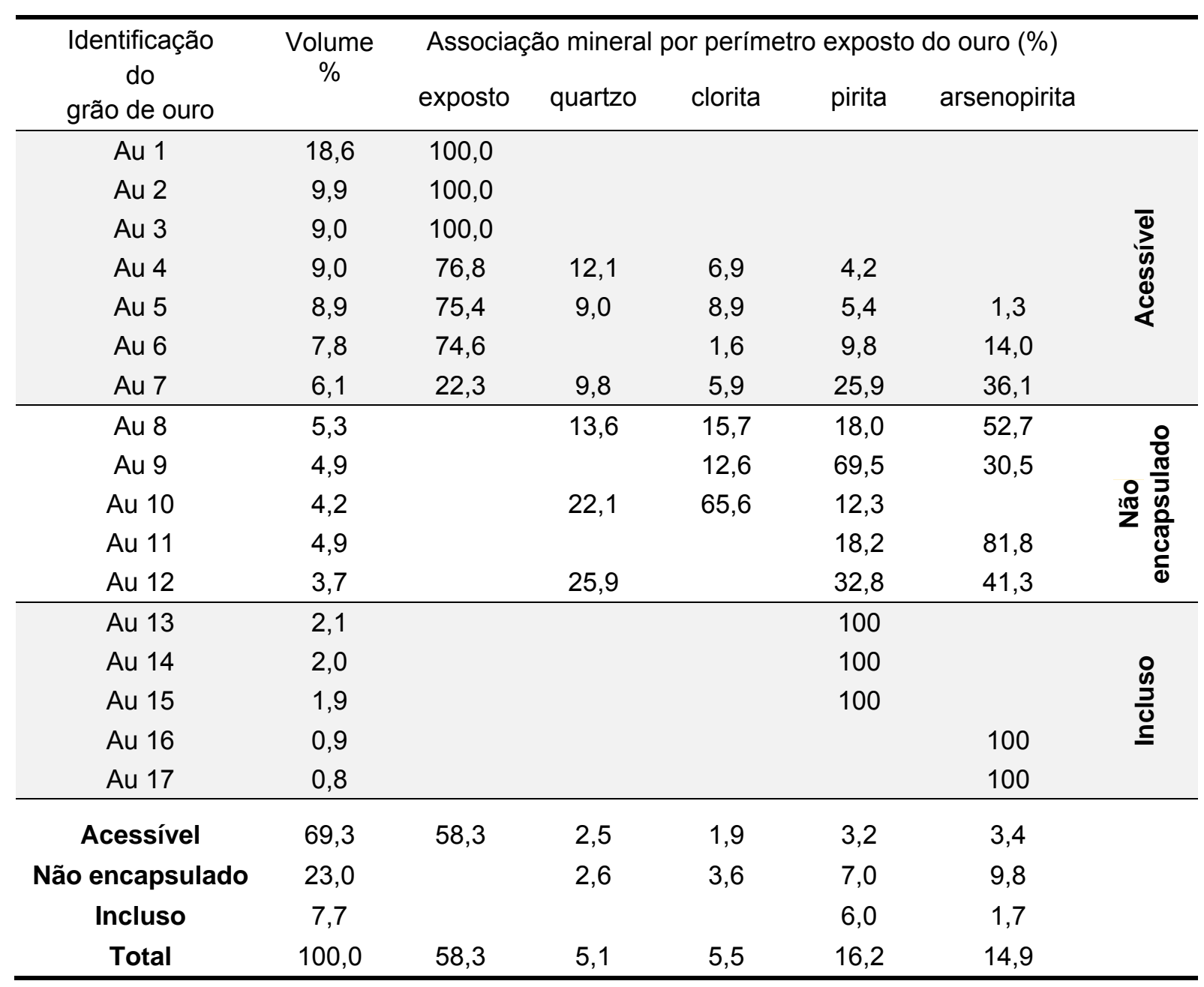

O perímetro exposto é calculado pela equação:

Perímetro exposto: $\Sigma \%$ volume de grãos com perímetro exposto $>0$

(eq. 2)

Na tabela, o perímetro exposto é dado pela soma da \% do volume dos grãos Au1 ao Au7 (eq. 2) maior de $0 \%$ de perímetro exposto. Esse valor mínimo de perímetro exposto é dado por pelo menos 1 pixel exposto. No exemplo da Tabela 3.2, essa somatória significa que $69,3 \%$ do volume dos grãos de ouro apresentam perímetro parcial ou totalmente exposto.

O cálculo dos grãos não encapsulados é obtido pela proporção em volume de grãos cujo perímetro exposto esteja associado a dois ou mais minerais. No exemplo acima, 
se dá pela soma dos grãos Au8 ao Au12, sendo que $23,0 \%$ do ouro está contido nesta associação, anteriormente representado na Fotomicrografia 2.2.

Os grãos inclusos são indicados pela associação em $100 \%$ com único mineral. A totalização é obtida pela somatória da \% volumétrica das fases associadas. No exemplo acima, os grãos inclusos respondem pelas células Au13 ao Au17. No exemplo citado, $6 \%$ do volume total de ouro está incluso na pirita e $1,7 \%$ na arsenopirita. 


\section{RESULTADOS}

\subsection{CORRELAÇÕES QUÍMICAS A PARTIR DO BANCO DE DADOS ANALÍTICO}

A análise dos dados analíticos disponibilizados pela Kinross considerou furos de sondagem que contém informações em intervalos de 1 metro dentro do limite de cada corpo mineralizado. No presente estudo foram levados em consideração os teores de arsênio, enxofre e ouro, pois são eles os elementos determinantes para a delimitação do corpo mineralizado.

A Figura 4.1 apresenta a relação entre os teores de arsênio e ouro para o intervalo de teor de ouro $(0-2,00$ ppm de Au) em 78.305 amostras. Para a relação de teores de enxofre e ouro, conforme se observa na Figura 4.2, foram consideradas 84.079 amostras. As amostras foram analisadas pelo método fire assay para ouro, enxofre pelo método de pirólise em forno de indução com determinação por célula de infravermelho e ICP-OES para As.

Figura 4.1 - Relação entre teores de arsênio e ouro - banco de dados da Kinross

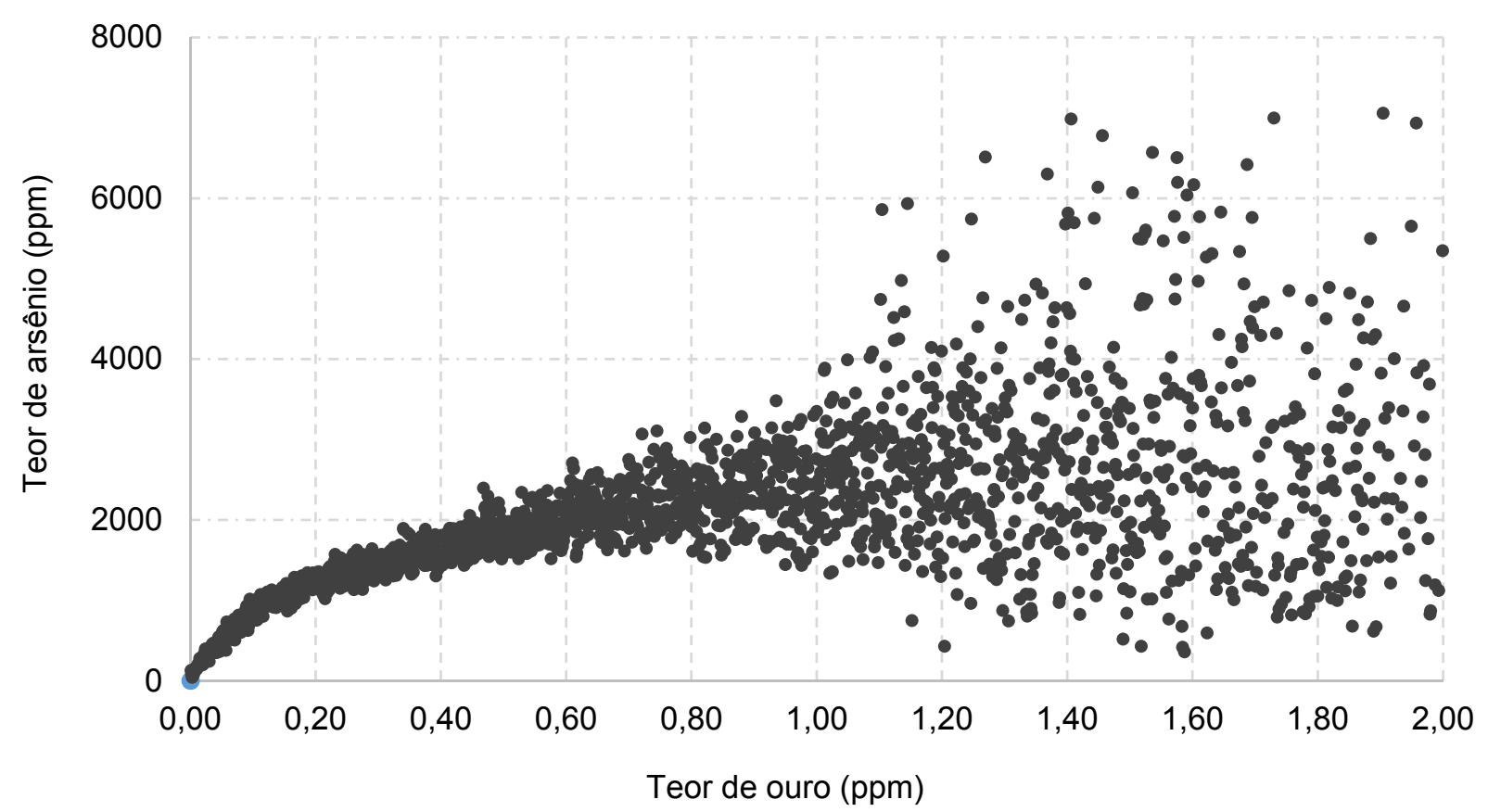

Os dados apresentados mostram uma elevada relação entre teores de ouro e arsênio principalmente em teores até 1 ppm de ouro; uma tendência dispersa de distribuição do arsênio é observada em teores mais elevados de ouro. Esse comportamento pode 
ser eventualmente interpretado como o efeito de clusters, aglomerações ou grãos de ouro com granulação grossa associados a arsenopirita ou pirita, conforme comportamento semelhante observado na Figura 4.2 para a relação entre teores de enxofre e ouro.

Figura 4.2 - Relação entre teores de enxofre e ouro - banco de dados da Kinross

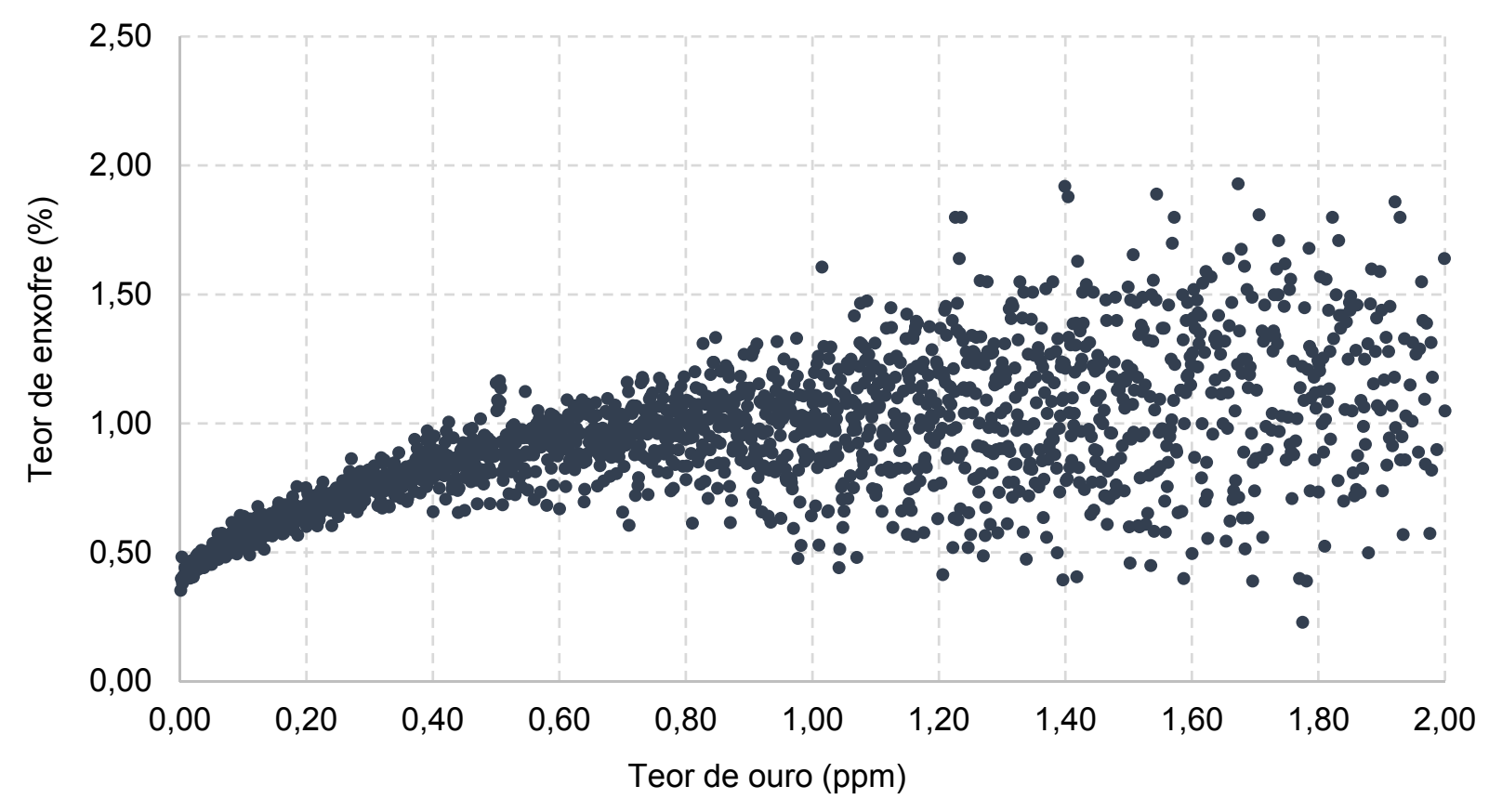

Tendo em vista as relações acima verificadas e que a distinção entre tipos de minérios para fins de lavra considera três classes distintas de teores de arsênio, optou-se, quando da apresentação dos resultados obtidos para as amostras estudadas, o ordenamento das amostras segundo teores crescentes de arsênio.

\subsection{CARACTERIZAÇÃO TECNOLÓGICA}

\subsubsection{Composição química das amostras estudadas}

A composição química das amostras foi determinada por espectrometria de fluorescência de raios $X$ (sem padrões), fire assay para determinação de ouro, pirólise em forno de indução para enxofre e ICP-OES para As, seguindo a mesma metodologia de análise das amostras disponíveis pelo banco de dados da empresa. 
Os teores obtidos para os óxidos maiores, S, As e Au são apresentadas no Apêndice 1, juntamente com informações relativas a amostragem ou proveniência das amostras: sondagens ou frentes de lavra.

Os teores obtidos por fluorescência de raios $\mathrm{X}$ mostram elevado conteúdo de $\mathrm{SiO}_{2}$ nas amostras $(53,1$ a $75,6 \%)$ devido principalmente a presença majoritária de quartzo. 0 $\mathrm{Al}_{2} \mathrm{O}_{3}$ apresenta teores entre 7,0 e 17,3\%, $\mathrm{MgO}$ de 0,55 a 1,46\%, $\mathrm{Na} 2 \mathrm{O}$ de 0,14 a 1,2\% e $\mathrm{K}_{2} \mathrm{O}$ entre 2,64 e 6,85\%; esses óxidos estão presentes principalmente na clorita, mica, caulinita e albita.

Os teores de arsênio ocorrem em uma ampla variação de teores, com mínimo de 229 ppm e máximo de 9121 ppm; os teores de enxofre variam entre 0,01\% e 4,51\%. Alguns outliers de arsênio podem ocorrer devido principalmente a presença de clusters de arsenopirita.

\subsubsection{Correlação entre teores nas amostras estudadas}

A Figura 4.3 apresenta a correlação entre os teores de enxofre, arsênio e ouro nas amostras estudadas.

Os resultados mostram uma leve tendência de crescimento dos teores de ouro juntamente com os teores de arsênio e enxofre, embora com baixos índices de correlação.

Quando correlacionados os teores de enxofre e arsênio, não se verifica relação direta entre os teores; fato que indica que os sulfetos com presença de arsênio, no geral, ocorrem de forma subordinada às demais fases minerais portadoras de enxofre.

O enxofre ocorre predominantemente na pirita, pirrotita e arsenopirita e em menor proporção na galena, esfalerita e calcopirita. Nas figuras seguintes, será possível observar a distribuição do enxofre nas amostras. Já a ocorrência de arsênio, está restrito a arsenopirita e em traços de arsenatos de ferro ( $\mathrm{FeAsO}$ ) e chumbo ( $\mathrm{PbAsO})$.

Os resultados obtidos pela Figura 4.3 em comparação com as Figura 4.1 e Figura 4.2 não apresentam uma relação clara pois o número de dados observados no banco de dados da empresa (por volta de 80.000 análises) é infimamente maior do que as amostras objeto do estudo de caracterização tecnológica. 
Figura 4.3 - Correlação entre teores de enxofre, arsênio e ouro nas amostras estudadas

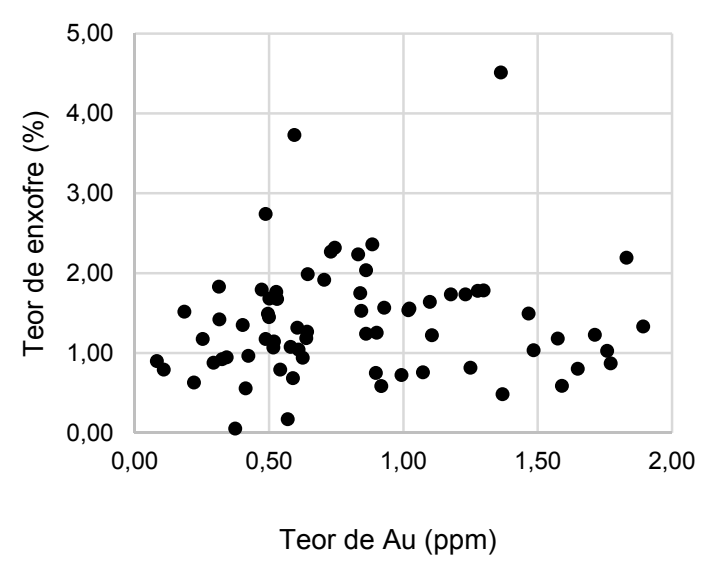

correlação entre enxofre e ouro

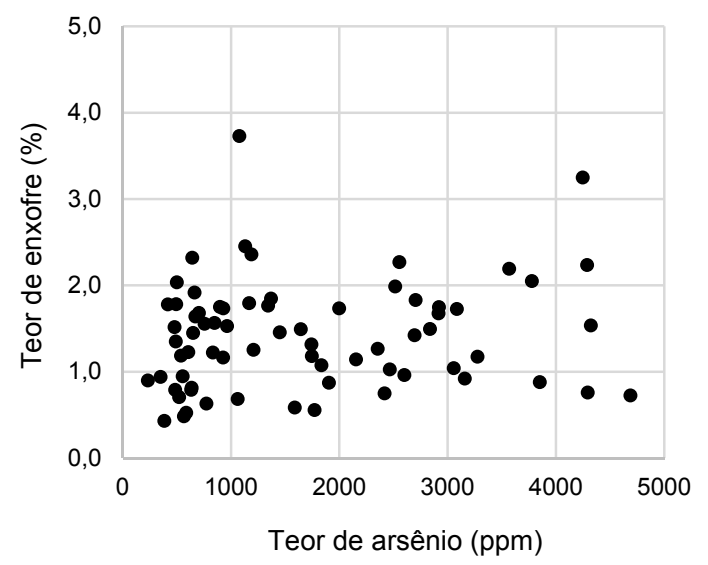

correlação entre enxofre e arsênio

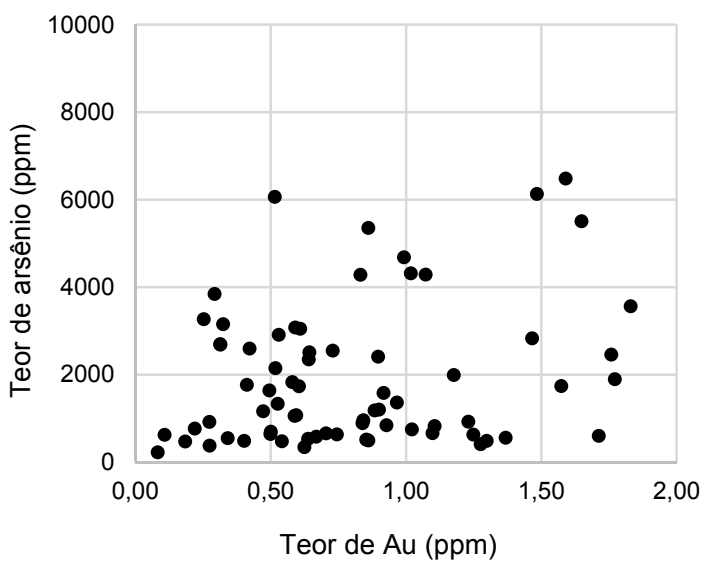

correlação entre arsênio e ouro

\subsubsection{Peneiramento em 0,020 mm}

As amostras estudadas foram objeto de peneiramento a úmido em 0,020 mm seguida de análise químicas com determinações de $S$, As e Au nos produtos obtidos. Estes resultados são apresentados nos Apêndice 2 e discutidos na sequência.

A distribuição de massa nas amostras está exposta na Figura 4.4. Os dados mostram que em média, 20 a 30\% das amostras constituem material passante em 0,020 mm nas condições de cominuição empregadas $(<0,50 \mathrm{~mm})$. 
Figura 4.4 - Distribuição de massa para peneiramento em $0,020 \mathrm{~mm}$

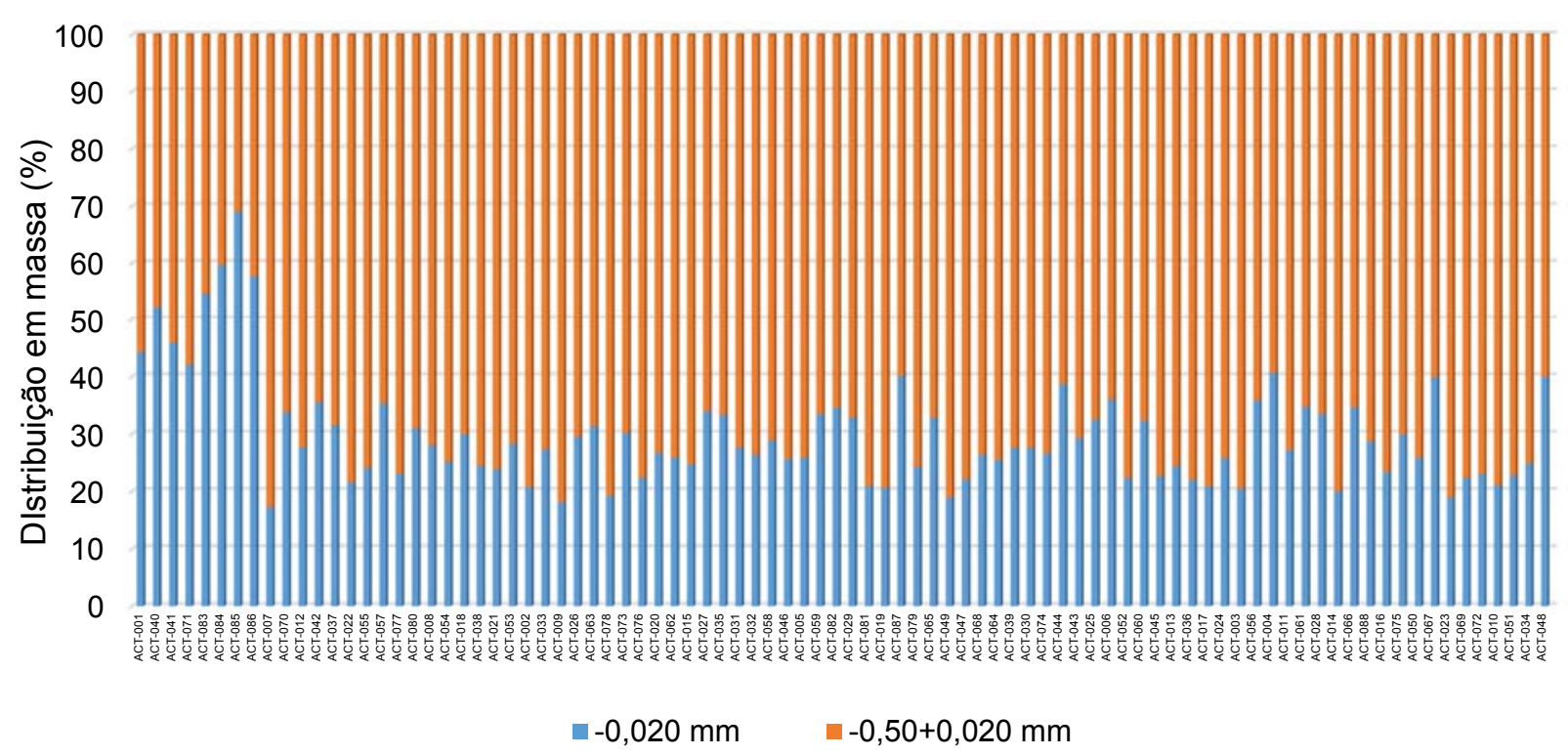

Amostras ACT-001, 040, 041, 071, 083, 084, 085, e 086 apresentam uma distribuição acima de $40 \%$ de finos abaixo da fração 0,020 mm. Esse comportamento mostra uma porção mais alterada do depósito principalmente quando relacionada ao seu conteúdo de sulfetos.

Em virtude desse comportamento, todos os histogramas a seguir serão apresentados com os resultados comparativos entre as amostras iniciando a esquerda com este conjunto de elevado conteúdo de finos (amostras ACT-001, 040, 041, 071, 083, 084, 085, e 086); as demais amostras estão organizadas nos histogramas em teores crescentes de arsênio da esquerda para a direita.

As distribuições de $S$, As e Au para os produtos gerados no peneiramento em 0,020 são apresentadas, respectivamente na Figura 4.5, Figura 4.6 e Figura 4.7 
Figura 4.5 - Distribuição de enxofre para peneiramento em 0,020 mm

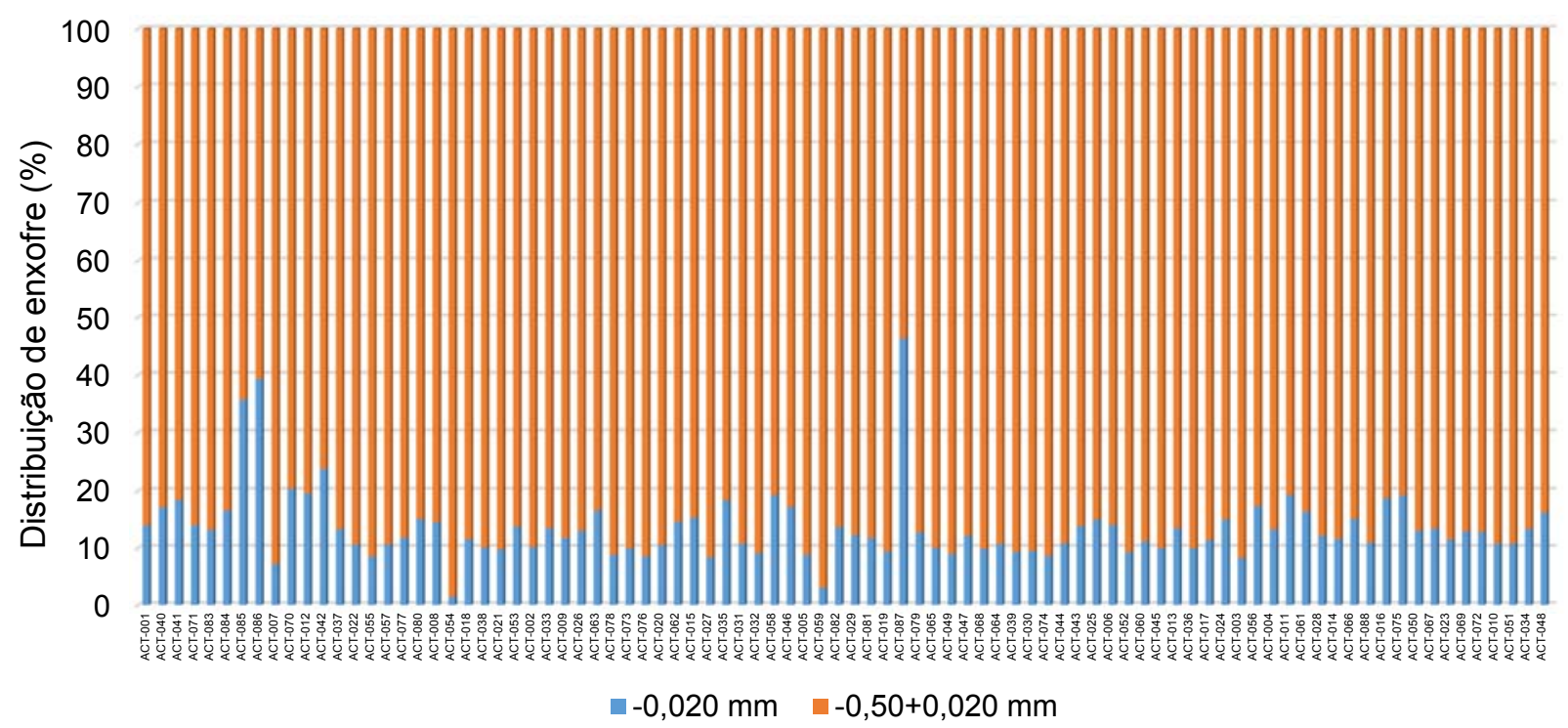

A média da distribuição de enxofre nas amostras estudadas é em torno de $14 \%$ sendo duas amostras com valores bem abaixo da média (ACT-054 e 059). A distribuição de enxofre nas amostras ACT-085, 086 e 087 ficaram acima de $30 \%$ na fração abaixo de $0,020 \mathrm{~mm}$.

Figura 4.6 - Distribuição de arsênio para peneiramento em 0,020 mm

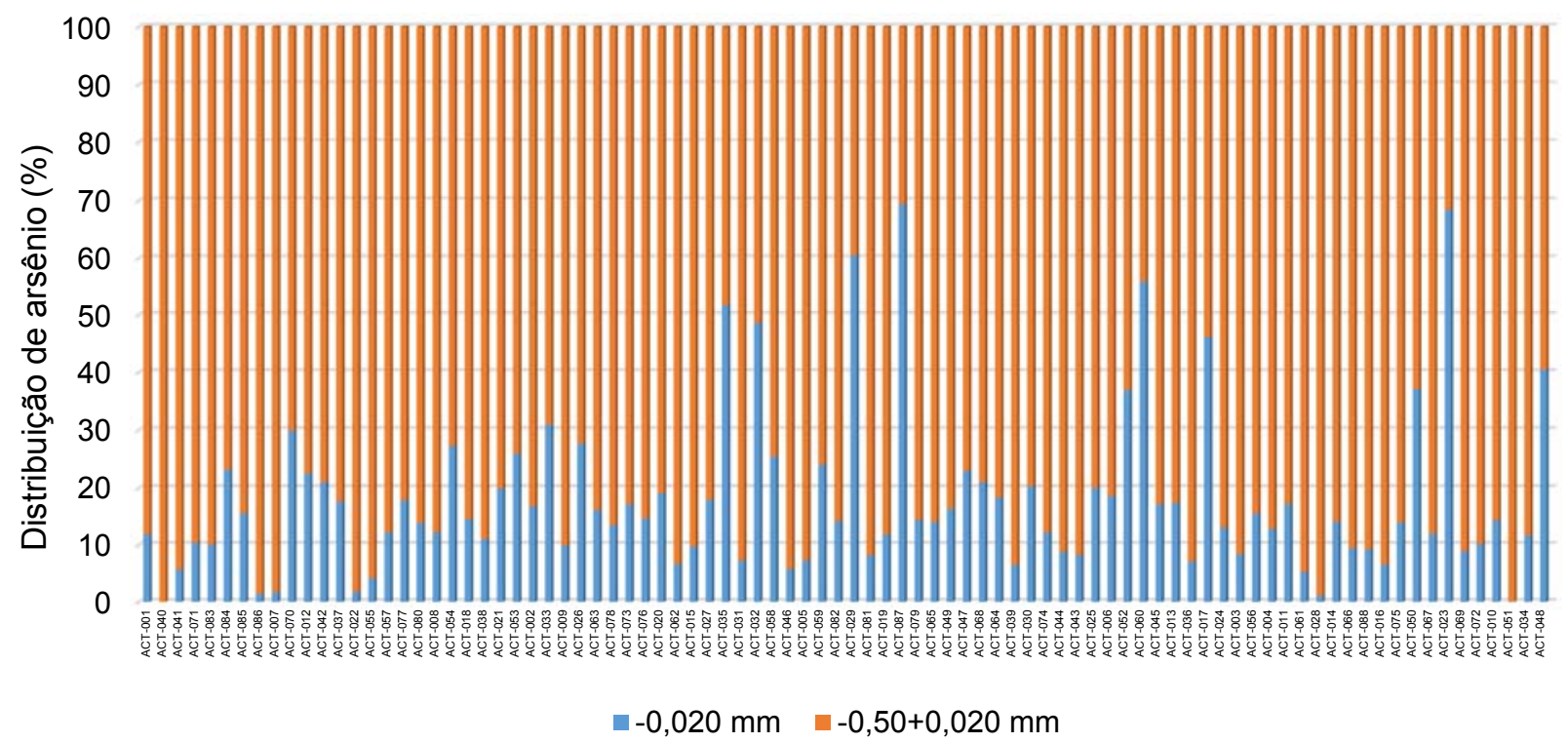


Os resultados para a distribuição de arsênio mostram que o conteúdo de arsênio na fração abaixo de 0,020 mm é superior a 40\% em algumas amostras: ACT-032, 060, 035, 017, 087, 023 e 029.

Figura 4.7 - Distribuição de ouro para peneiramento em 0,020 mm

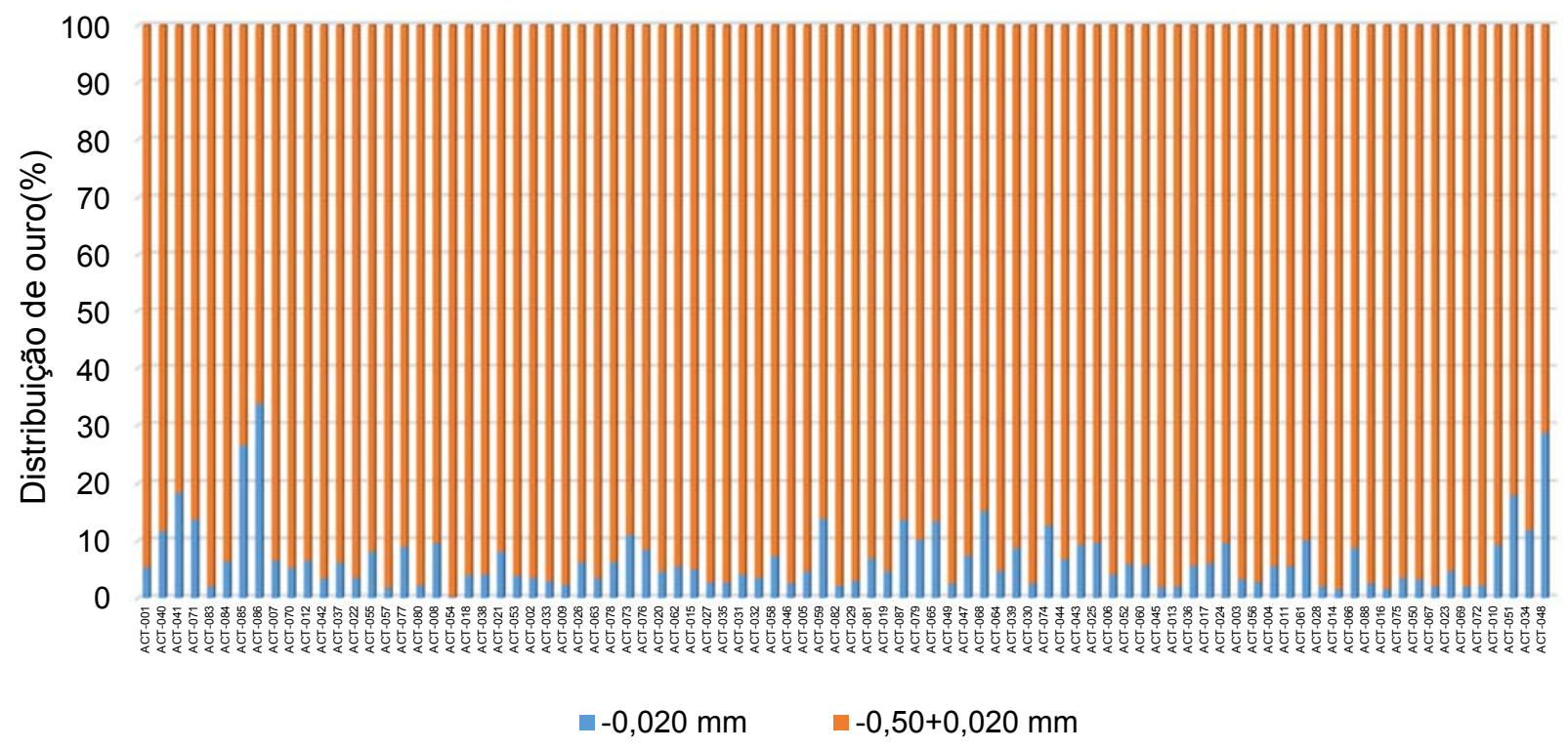

A Figura 4.7 indica que em média de $93 \%$ do ouro contido na amostra está associado ao material retido na fração acima de 0,020 mm (teores médios de 1,7 e 0,21 ppm de $\mathrm{Au}$, respectivamente, para as frações retida e passante em 0,020mm). Destacam-se amostras com proporção de finos acima de $40 \%$ em massa que apresentam proporções de ouro acima da $20 \%$ no material passante de $0,020 \mathrm{~mm}$ (amostras ACT048, 085 e 086). Em contraposição, verificam-se também amostras com mais de $98 \%$ do ouro contido acima de 0,020 mm (ACT-045, 013, 054, 067, 069 e 072).

\subsubsection{Separação minerais por líquido denso}

As frações retidas em $0,020 \mathrm{~mm}$ foram objeto de separações minerais em líquidos densos com emprego de tetra-bromo-etano $\left(\mathrm{d}=2,96 \mathrm{~g} / \mathrm{cm}^{3}\right)$ seguida de análise químicas com determinações de $S$, As e Au nos produtos flutuado e afundado obtidos. Além disso, o produto afundado foi objeto de estudo em seção transversal para estudo das características dos grãos de ouro. 
Estas separações foram realizadas com o intuito de concentrar os minerais de interesse nos produtos afundados para que se tenha uma melhor estatística e robustez no estudo das partículas portadores de ouro. Estes resultados são apresentados nos Apêndice 3 e discutidos na sequência.

A distribuição em massa dos produtos flutuados e afundados nas amostras está exposta na Figura 4.8. Os dados indicam que, em média, a fração afundada representa cerca de $12 \%$ em massa e contêm aproximadamente $95 \%$ do enxofre, $85 \%$ do arsênio e $95 \%$ do ouro contido.

A amostra ACT-087 apresenta uma distribuição em massa no produto afundado muito elevado em relação às outras amostras (54\% da massa total). Esse comportamento é resultado pela elevada quantidade de minerais de alta densidade presentes nesta amostra, tais como ilmenita, rutilo e goethita.

Figura 4.8 - Distribuição em massa para separações em líquido denso (fração$0,50+0,020 \mathrm{~mm})$

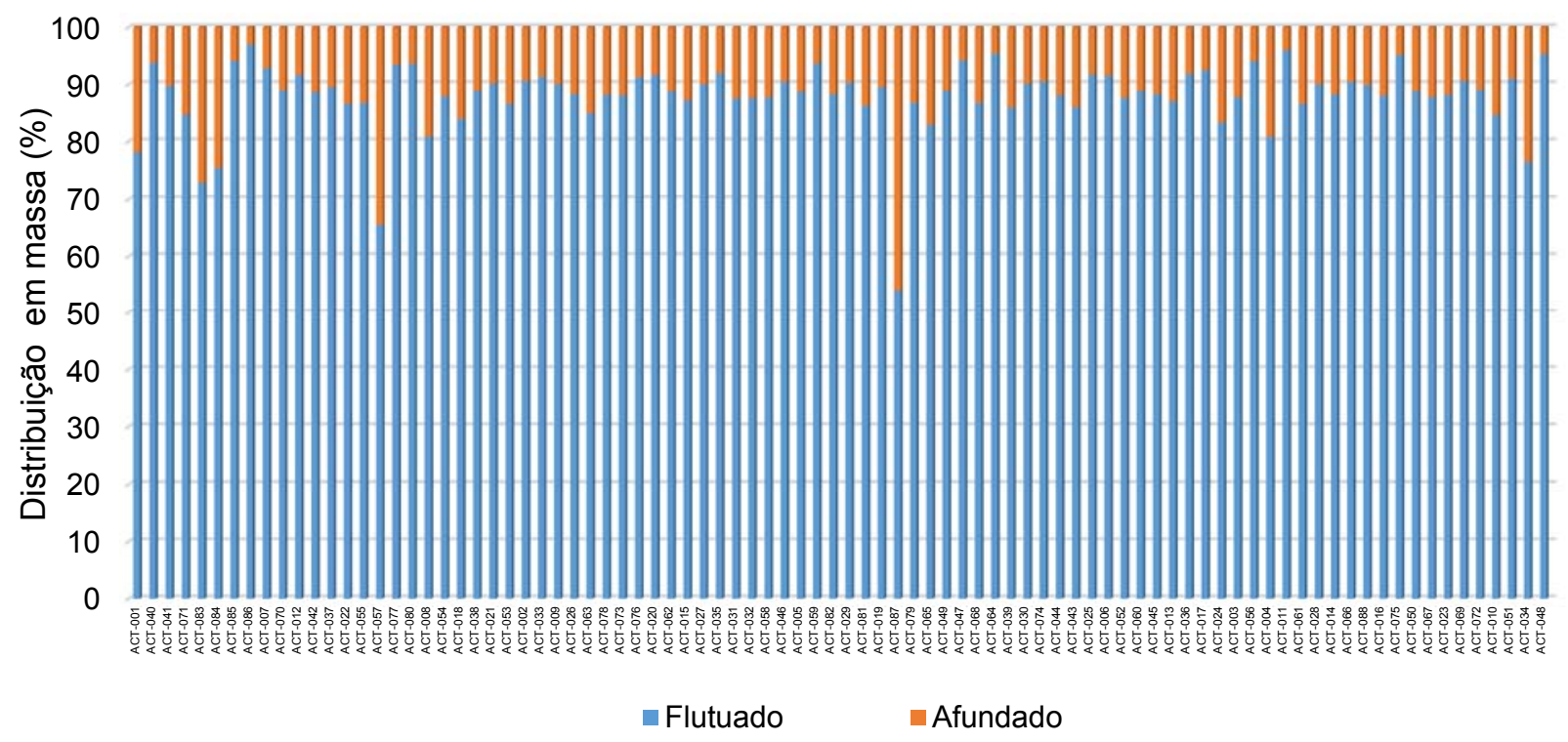

As distribuições de $S$, As e Au para os produtos gerados nas separações em líquido denso são apresentadas, respectivamente, na Figura 4.9, Figura 4.10 e Figura 4.11. 
Figura 4.9 - Distribuição de enxofre para separações em líquido denso (fração $0,50+0,020 \mathrm{~mm}$ )

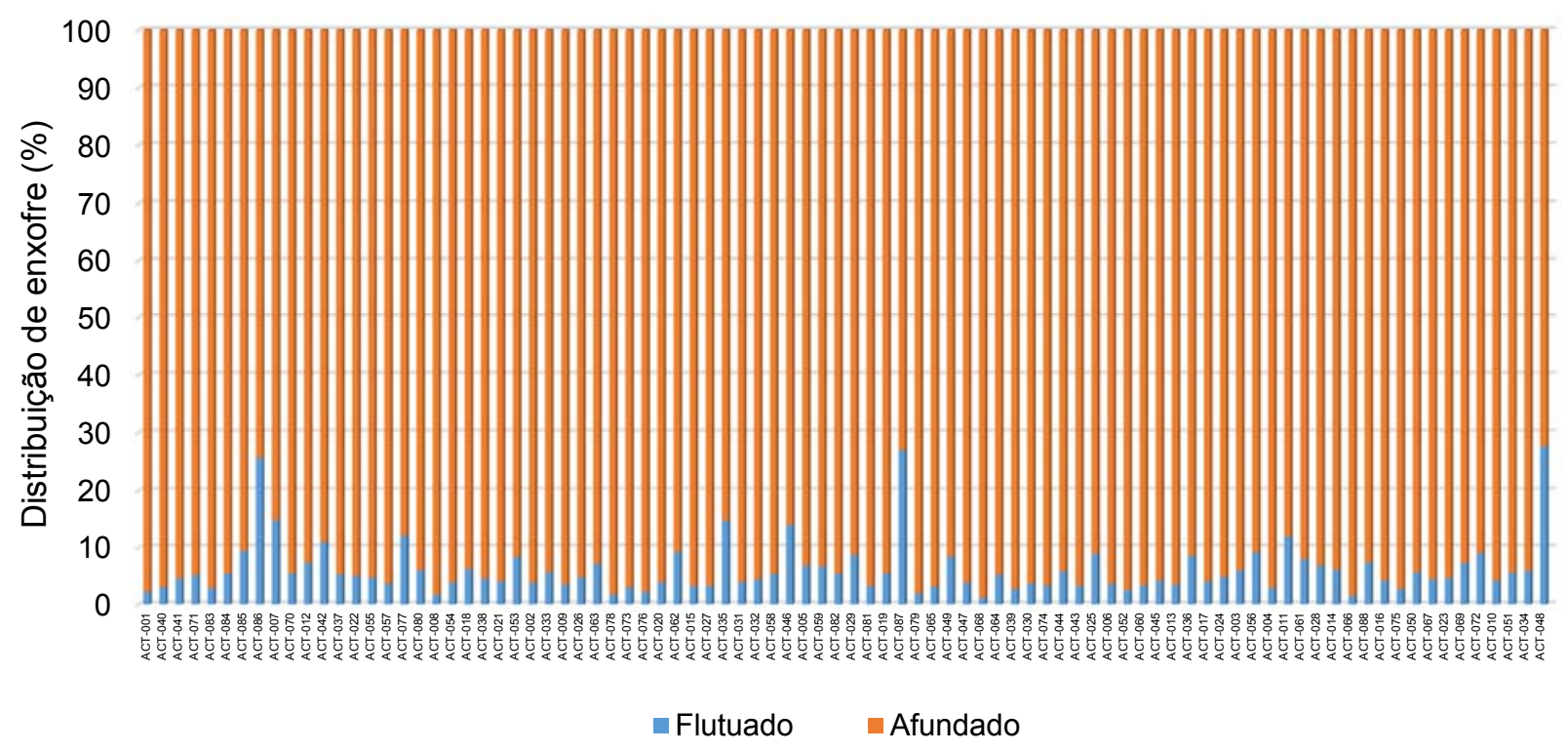

O enxofre na fração acima $0,020 \mathrm{~mm}$ está associado principalmente ao produto afundado, perfazendo cerca de $95 \%$ do total contido. Os produtos flutuados das amostras ACT-086, 087 e 048 apresentam proporções significativamente acima da média, com 25,6; 26,9 e 27,2\%, respectivamente (esse comportamento é reflexo principalmente de maior parcela de partículas mistas de sulfetos associadas a silicatos. A Figura 4.10 apresenta a distribuição de arsênio na fração acima 0,020 mm. Para as amostras (ACT- 007, 032, 060, 053, 087, 052, 050 e 024) o arsênio apresenta significativa associação com o produto flutuado, com proporções acima de $40 \%$ do contido na fração retida em 0,020 mm. Esse conjunto de amostras se assemelha ao já discutido para a distribuição de enxofre; há uma tendência de uma maior interação da arsenopirita no flutuado na forma de partículas mistas com silicatos, o que difere no comportamento da distribuição do arsênio destas amostras. 
Figura 4.10 - Distribuição de arsênio para separações em líquido denso (fração $0,50+0,020 \mathrm{~mm})$

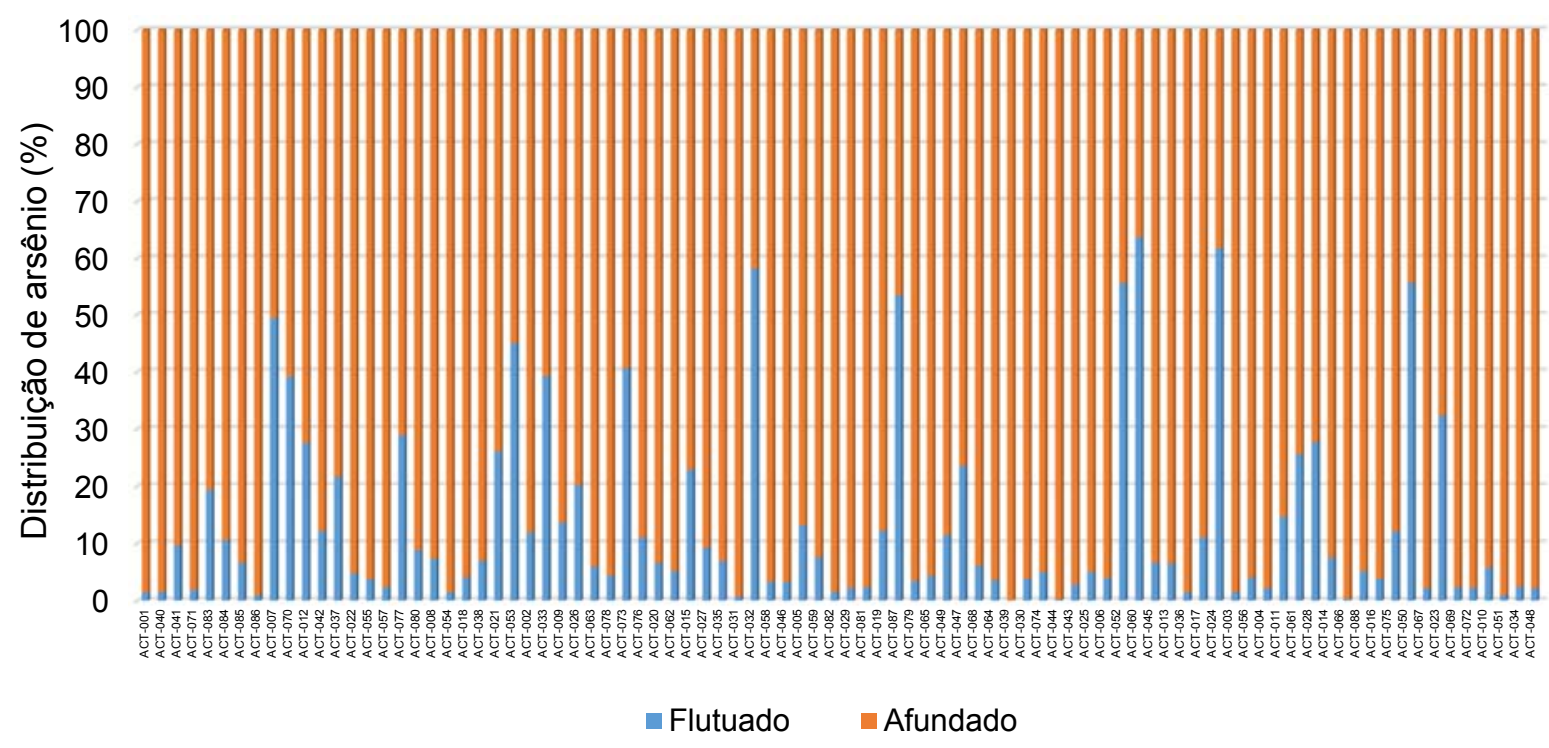

A Figura 4.11 indica que nas amostras estudadas, em média de $85 \%$ do ouro contido na fração acima de 0,020 mm está associado ao produto afundado (teores médios de 0,22 e 17,5 ppm de Au, respectivamente, para o flutuado e o afundado). A distribuição de ouro nos produtos, em geral, se apresenta majoritariamente no produto afundado (84\%) com algumas amostras com maior contribuição no produto flutuado.

Figura 4.11 - Distribuição de ouro para separações em líquido denso (fração $0,50+0,020 \mathrm{~mm}$ )

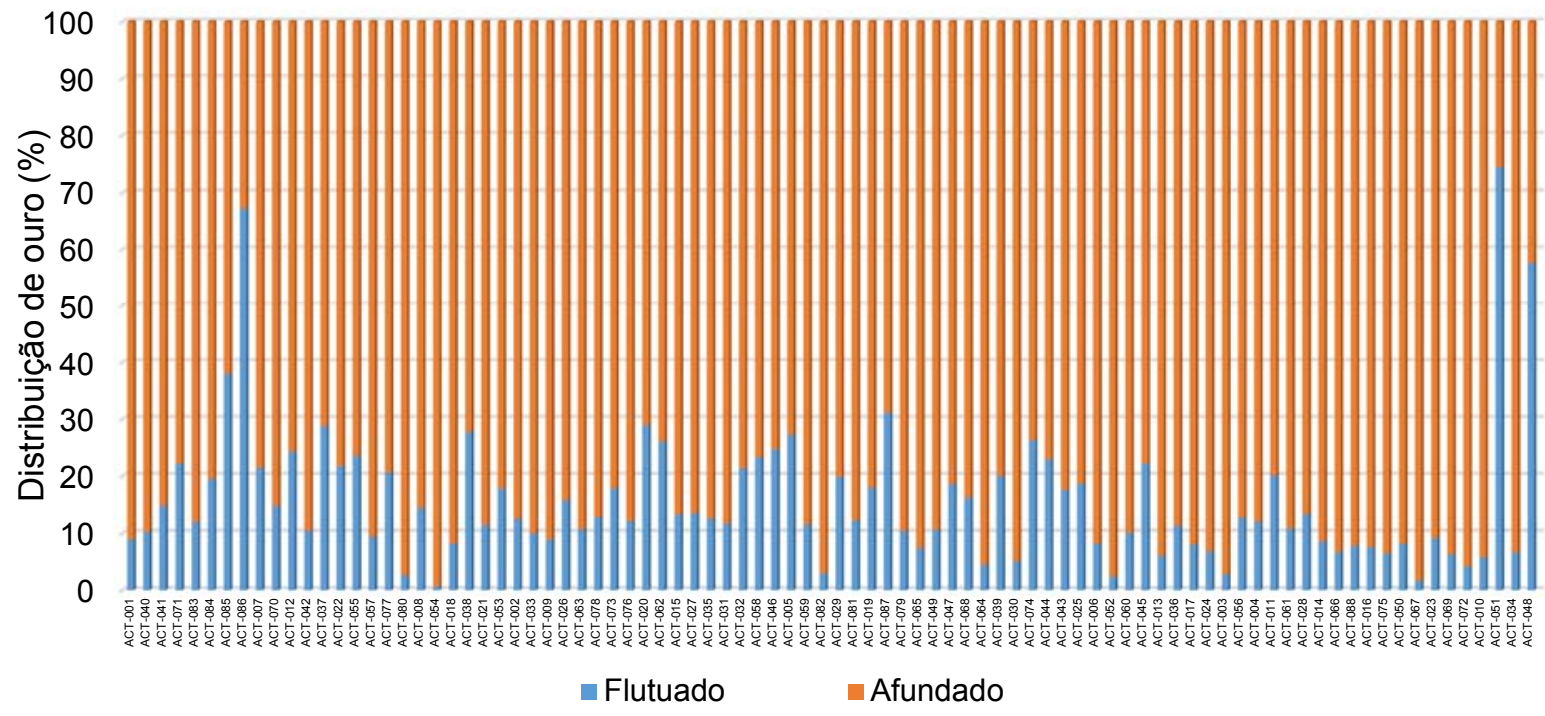


As amostras ACT-048 e 051 apresentam maiores conteúdos de ouro associado a silicatos (quartzo, albita, clorita), 3,0 e 15\% respectivamente; essa associação está refletida em um aumento nos teores de $A u$ nos produtos flutuados (ACT-051: 0,42 ppm; ACT-048: 0,41 ppm). A amostra ACT-086 apresenta uma quantidade muito grande quartzo, possivelmente associado aos boudins.

As amostras ACT-054, 080 e 087 apresentam ouro exclusivamente no produto afundado da fração $+0,020 \mathrm{~mm}$. Esse comportamento é em virtude do menor conteúdo de silicatos nestas amostras ${ }^{22}$.

\subsubsection{Composição mineralógica das amostras estudadas}

Os difratogramas de raios $\mathrm{X}$ obtidos para as amostras apresentaram semelhanças em termos de posição e intensidades relativas entre picos, o que mostra uma mineralogia semelhante entre as amostras.

A Figura 4.12 apresenta a sobreposição dos 88 difratogramas gerados para cada amostra.

O eixo x da figura traz a posição ( ${ }^{\circ} 2$ Theta) entre 5 e $40^{\circ}$ com a identificação dos picos relacionados às principais fases minerais constituintes. Observa-se que alguns picos ocorrem em amostras especificas, como por exemplo, fase constituída por caulinita + clorita (pico em laranja) e goethita (pico em vermelho).

${ }^{22}$ Amostra ACT-087 com $18 \%$ do ouro associado a goethita $+75 \%$ exposto; amostra ACT-054 com $97 \%$ associado do ouro a sulfetos + exposto e amostra ACT-080 com $93 \%$ do ouro associado a arsenopirita e $3 \%$ a pirita. 
Figura 4.12 - Sobreposições dos difratogramas de raios $X$ das amostras estudadas

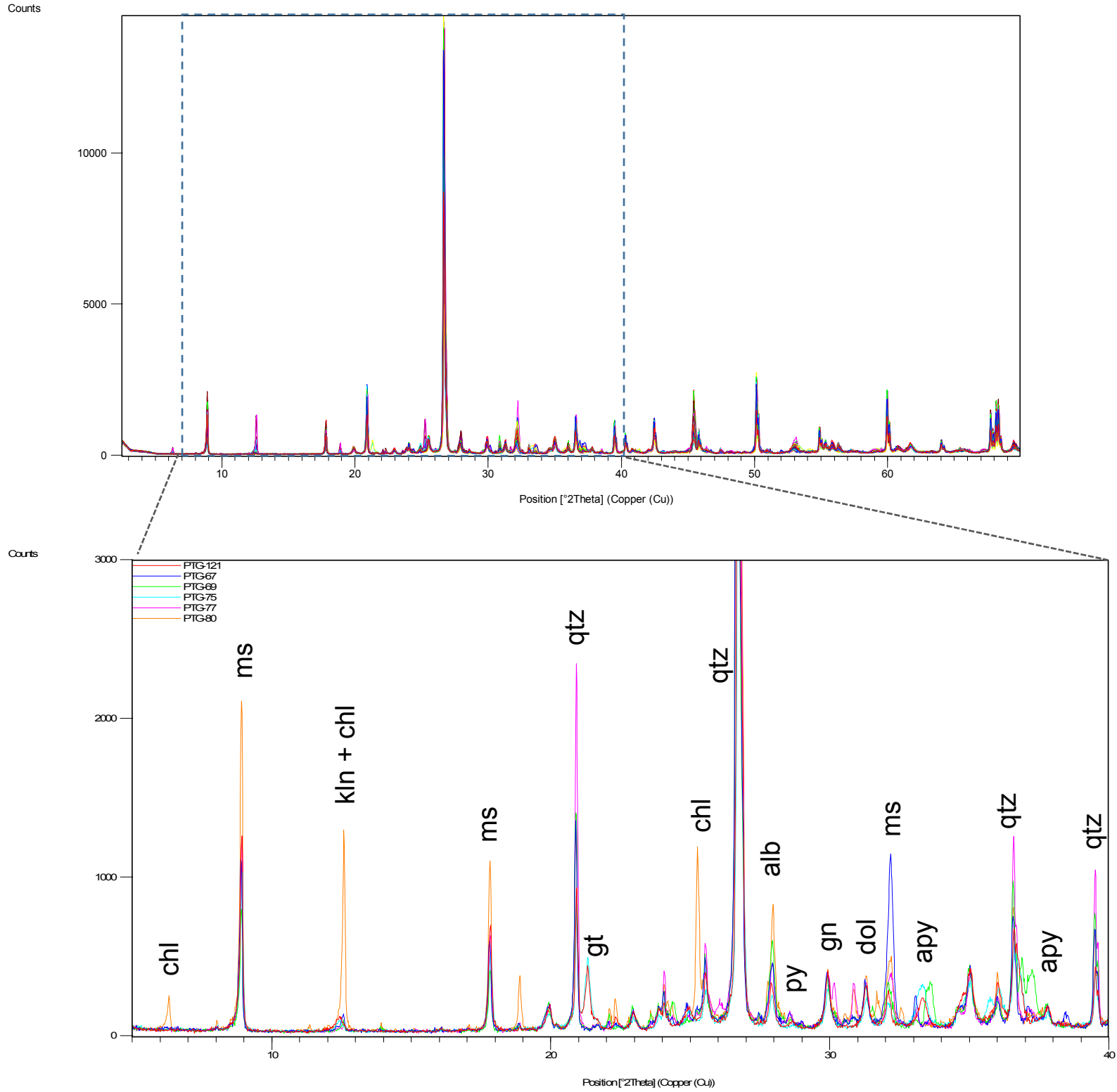

Legenda: chl: clorita; ms: muscovita; kIn: caulinita; qtz: quartzo; gt: goethita; alb: albita; dol: dolomita; py: pirita; apy: arsenopirita; gn: galena.

Entre os minerais de maiores proporções identificados, o quartzo e muscovita foram recorrentes em todas as amostras. Constituintes minerais em menores proporções tais como feldspato (albita), goethita, clorita (clinocloro), caulinita, sulfetos (arsenopirita, pirita, galena) e três variedades de carbonatos: dolomita, anquerita e siderita, ocorrem em proporções variadas nas amostras.

As composições mineralógicas determinadas por MEV-MLA para a fração 0,50+0,020 $\mathrm{mm}$ evidenciam a presença considerável de quartzo e mica, que somadas 
respresentam, em média, $80 \%$ do total. O conjunto de amostras apresenta aproximadamente $10 \%$ de carbonatos (siderita e anquerita), cerca de $5 \%$ de sulfetos (pirita, arsenopirita, pirrotita, calcopirita, esfalerita e galena) e menores proporções de albita, clorita, goethita, ilmenita, rutilo e outros (zircão, cromita, monazita, FeAsO, Au, AlFe-PbAsO, apatita).

A Figura 4.13 apresenta as composições mineralógicas (\% em massa) para as frações retidas em 0,020 $\mathrm{mm}$. Algumas destas se destacam por apresentarem composições mineralógicas distintas:

- A amostra ACT-087: elevado conteúdo de clorita, goethita+ilmenita+rutilo e ausência de sulfetos.

- A amostra ACT-086: elevado conteúdo de quartzo (78\% da massa total) o que sugere um um nível de boudin com baixa proporção de sulfetos $(0,02 \%$ da massa total da amostra) e grande contribuição de ouro no produto flutuado (65\% da distribuição).

Figura 4.13 - Composição mineralógica das amostras estudadas (fração -0,50+0,020 $\mathrm{mm}$ )

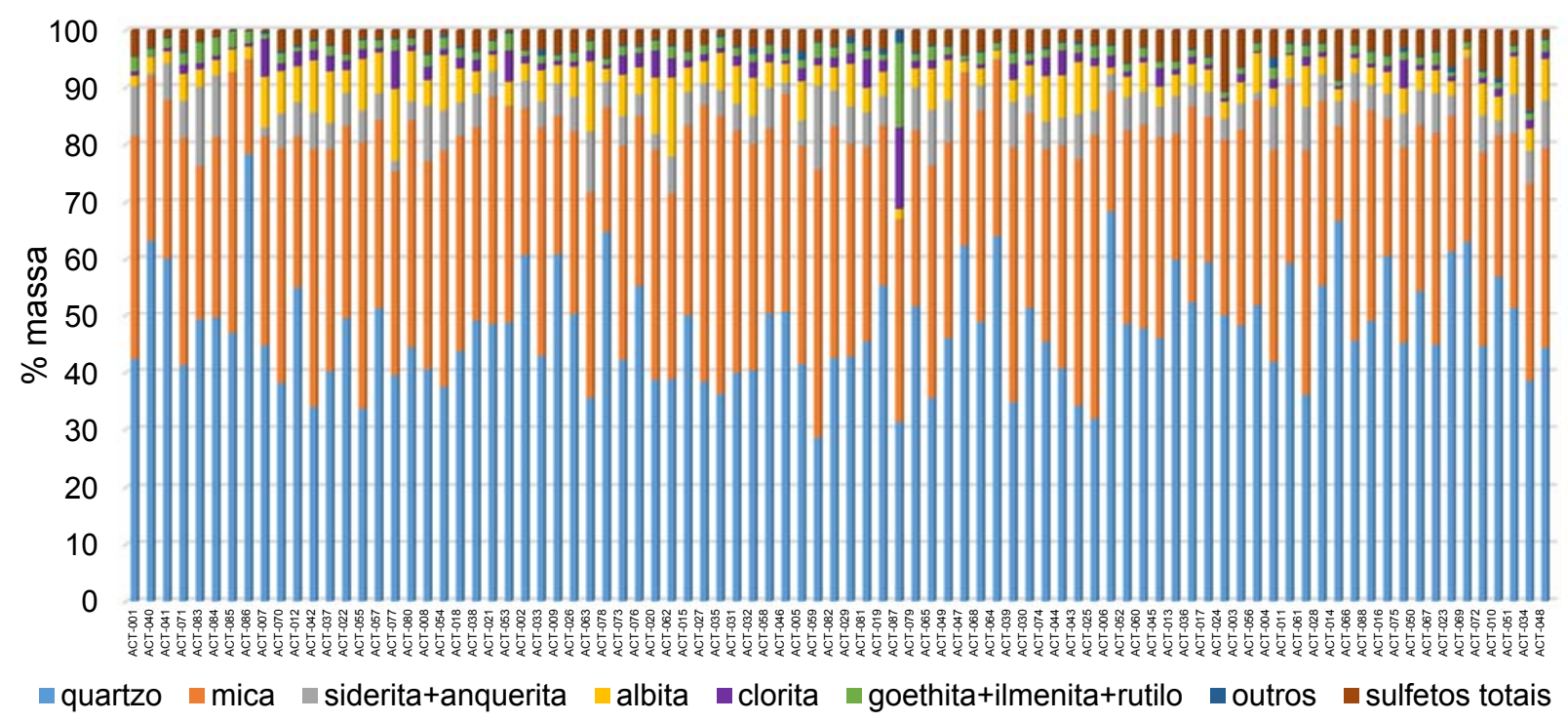

outros: zircão, cromita, monazita, $\mathrm{FeAsO}, \mathrm{Au}, \mathrm{AlFe}-\mathrm{PbAsO}$, apatita; sulfetos totais: pirita, arsenopirita, pirrotita, calcopirita, esfalerita e galena 
O Apêndice 4 apresenta a composição mineralógica detalhada das amostras estudadas.

A Figura 4.14 apresenta comparativamente a distribuição normalizada dos sulfetos (\% em massa). Verifica-se o predominio de pirita e de arsenopirita com pirrotita subordinada. Com o incremento dos teores de arsênio tem-se, paralelamente, expressivo incremento na relação arsenopirita/pirita.

Algumas amostras tem um comportamento distinto:

- pirrotita: em algumas amostras as proporções de pirrotita dentre os sulfetos pode atingir valores de 20 a 53\% relativos (ACT-042, 035, 080, 009, 063, 062, 014, 054, 086 e 048).

- outros sulfetos (calcopirita, esfalerita e galena): a amostra ACT-079 tem uma proporção de $44 \%$ de outros sulfetos, sendo que as amostras ACT- 001, ACT22, ACT-078 e 087 também mostram conteúdos expressivos (15 a 25\% do total de sulfetos).

Figura 4.14 - Composição normalizada dos sulfetos (fração -0,50+0,020mm)

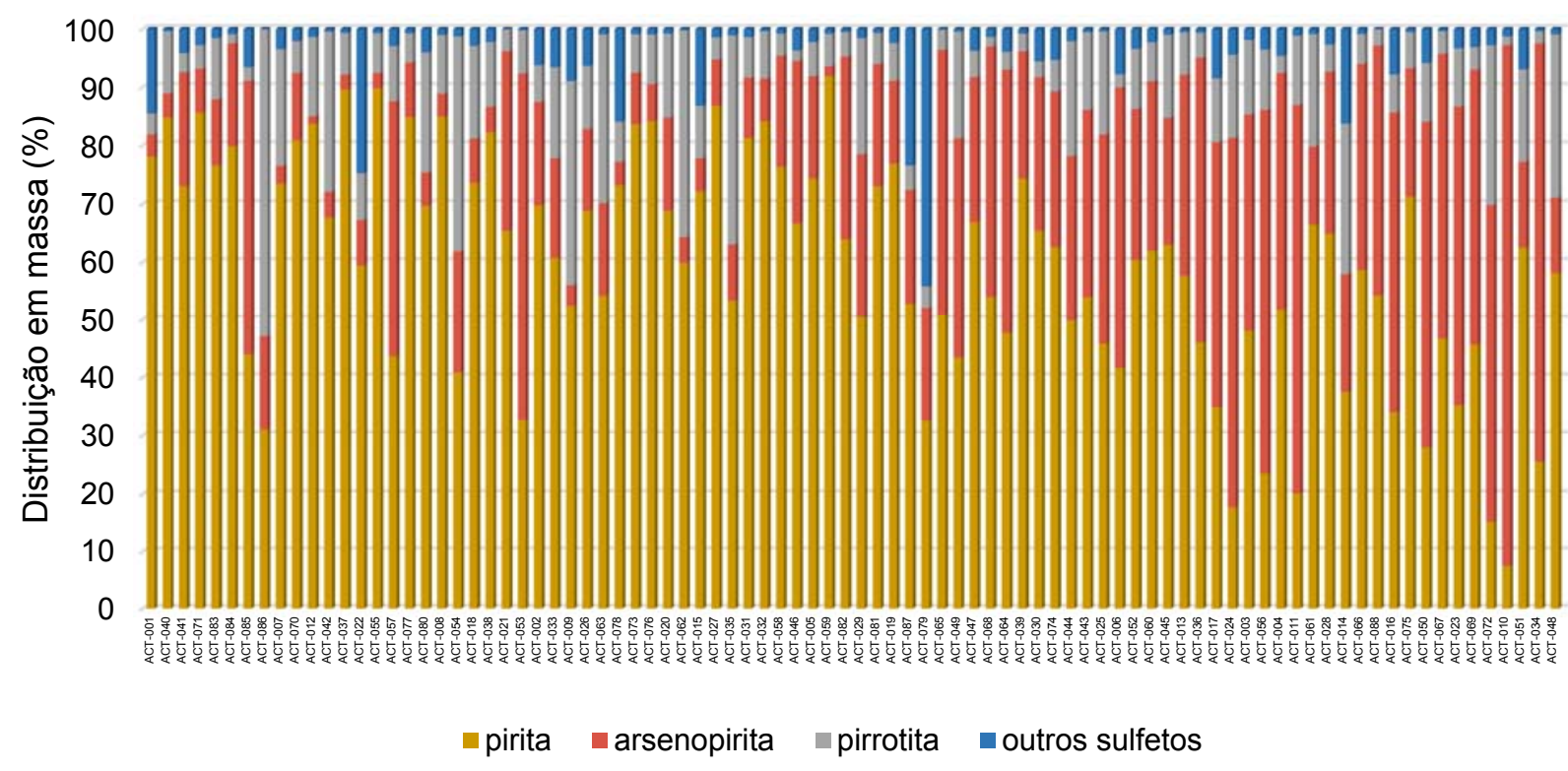

outros sulfetos: calcopirita, esfalerita e galena 
4.2.6 Distribuição de enxofre entre os principais sulfetos

A distribuição de enxofre nas amostras foi obtida partir do sistema MLA para a fração $-0,50+0,020 \mathrm{~mm}$ sendo apresentada na Figura 4.15.

A composição teórica do enxofre nos três principais sulfetos presentes é de $53,4 \%$ na pirita, 37,6\% na pirrotita e 19,6\% na arsenopirita. Em virtude da elevada distribuição em massa de pirita nas amostras e da composição majoritária de enxofre nessa fase, o enxofre se concentra principalmente na fase.

Figura 4.15 - Distribuição de enxofre entre os principais sulfetos (fração -0,50+0,020 $\mathrm{mm}$ )

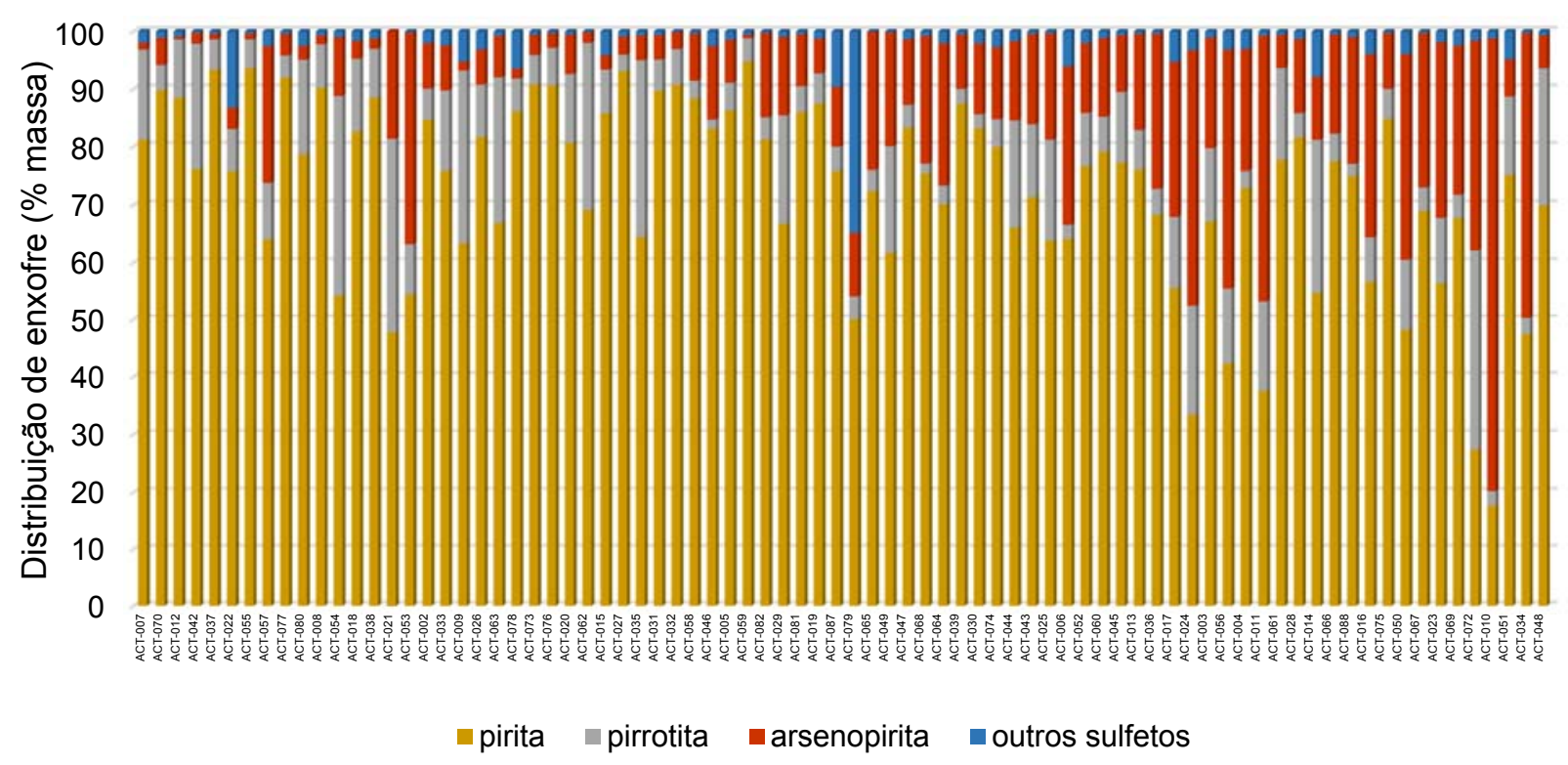

outros sulfetos: calcopirita, esfalerita e galena

A relação entre a distribuição em massa de sulfetos nas amostras e os respectivos teores de enxofre (Figura 4.16) apresenta boa correlação o que demonstra uma relação direta entre seus conteúdos.

O Apêndice 5 apresenta a distribuição de enxofre nas amostras estudadas. 
Figura 4.16 - Correlação entre sulfetos na amostra e teor de enxofre (fração $0,50+0,020 \mathrm{~mm})$

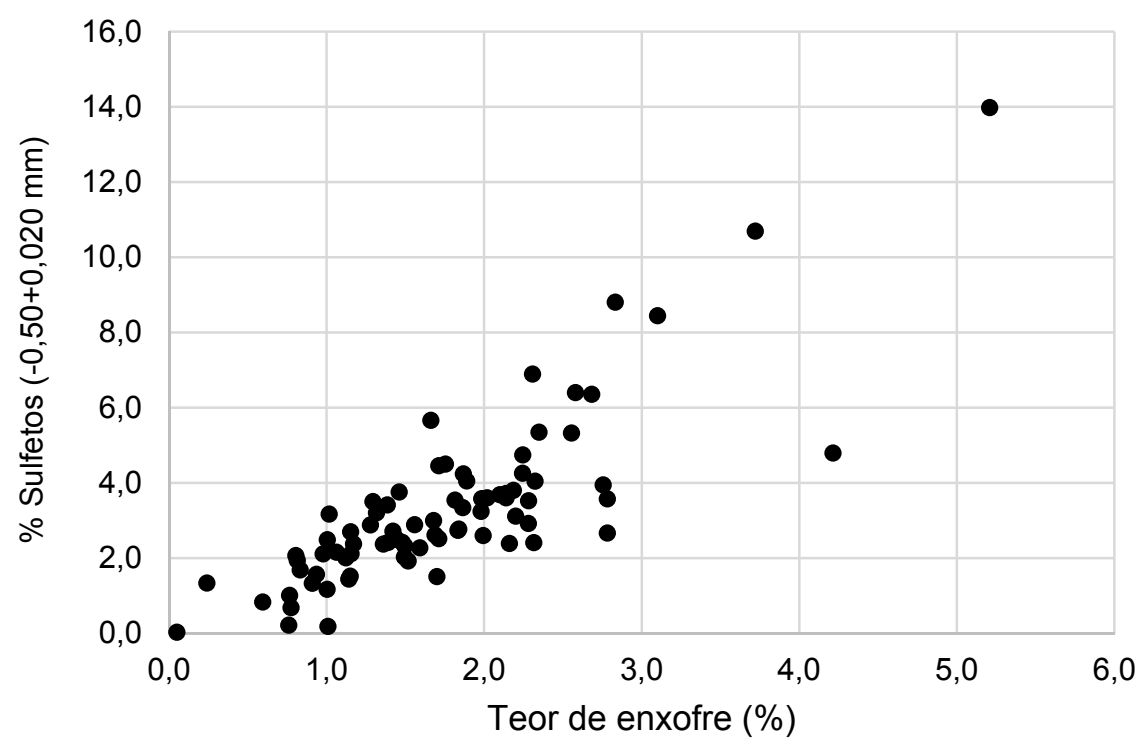

4.2.7 Tamanho de grãos de ouro e de clusters de sulfetos

As medianas das distribuições de tamanho dos grãos de ouro e dos cluster de sulfetos identificados no MLA são detalhadas, respectivamente, nos Apêndices 6 e 7 e ilustradas comparativamente na Sulfetos global: média ponderada pelo tamanho dos grãos dos sulfetos pirita, arsenopirita, pirrotita, calcopirita, esfalerita e galena; ECD: diâmetro de círculo equivalente.

Figura 4.17 e Figura 4.18.

Para os sulfetos foram determinadas as dimensões dos clusters ou agregados sem a individualização de grãos. A mediana dos diâmetros médio do círculo equivalente ( $\mathrm{d}_{50}$ - ECD) para os vários clusters de sulfetos identificados e o global de sulfetos é apresentado na Tabela 4.1.

Tabela 4.1 - Medianas das distribuições de tamanho de sulfetos (D50 - $\mu \mathrm{m}$; ECD) nas amostras estudadas

\begin{tabular}{cccccccc}
\hline $\mathrm{D}_{\mathbf{5 0}}(\boldsymbol{\mu m})$ & $\begin{array}{c}\text { sulfetos } \\
\text { global }\end{array}$ & pirita & arsenopirita & pirrotita & calcopirita & esfalalerita & galena \\
\hline mediana & 101 & 98 & 134 & 51 & 34 & 46 & 39 \\
máximo & 8 & 14 & 14 & 4 & 7 & 4 & 6 \\
Mínimo & 200 & 192 & 460 & 220 & 155 & 206 & 270 \\
\hline
\end{tabular}


Sulfetos global: média ponderada pelo tamanho dos grãos dos sulfetos pirita, arsenopirita, pirrotita, calcopirita, esfalerita e galena; ECD: diâmetro de círculo equivalente.

Figura 4.17 - Medianas das distribuições de tamanho de grãos de ouro ( $D_{50}$; ECD)

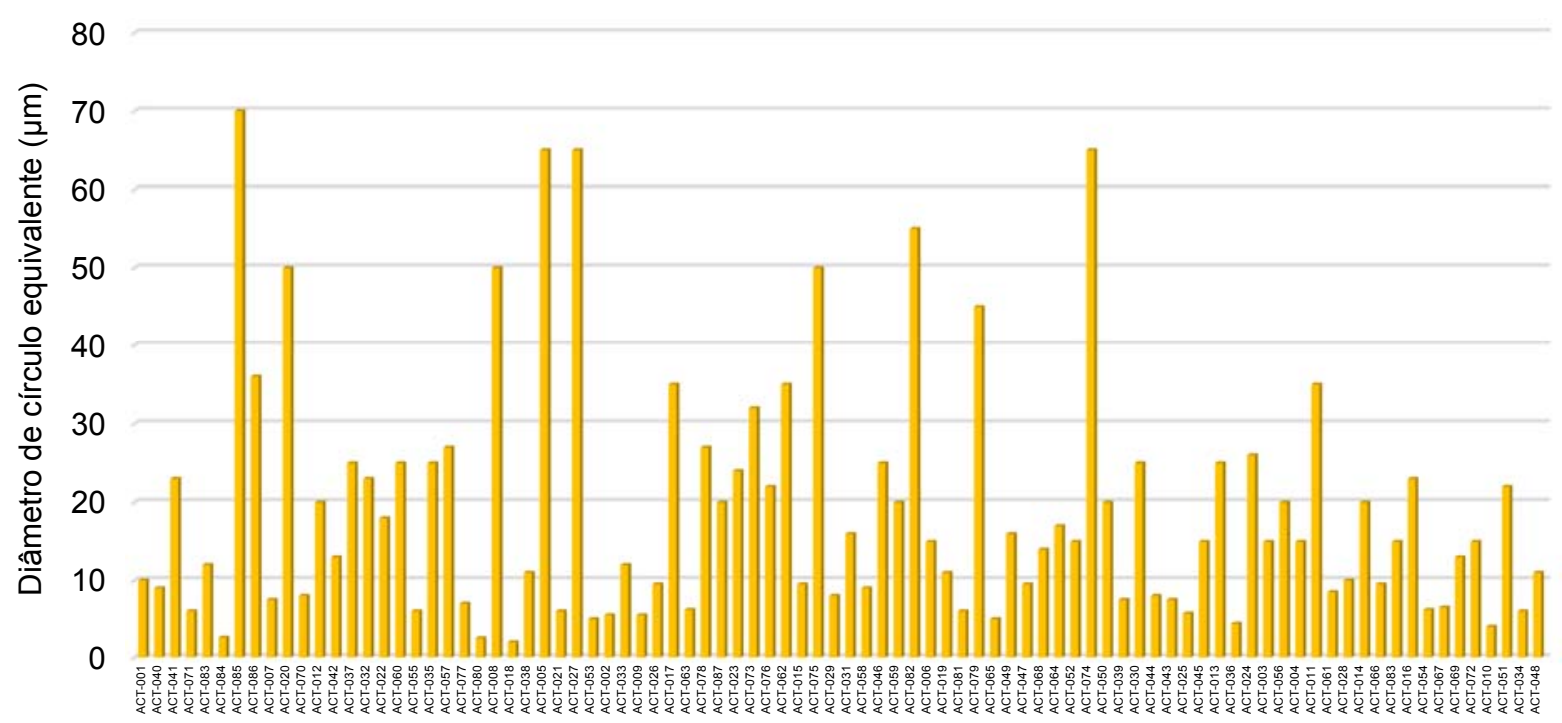

As medianas das distribuições apresentam um valor médio de $19 \mu \mathrm{m}$ com grande dispersão, não sendo possível relacionar com outras variáveis avaliadas (máximo de $70 \mu \mathrm{m}$ e mínimo de $2 \mu \mathrm{m}$ ). Pouco menos de $10 \%$ das amostras apresentam valores de $D_{50}$ dos grãos de ouro acima de 50 um (ACT-005, 027, 074, 082 e 085). 
Figura 4.18 - Medianas das distribuições de tamanho para clusters de sulfetos $\left(D_{50}\right.$; ECD)

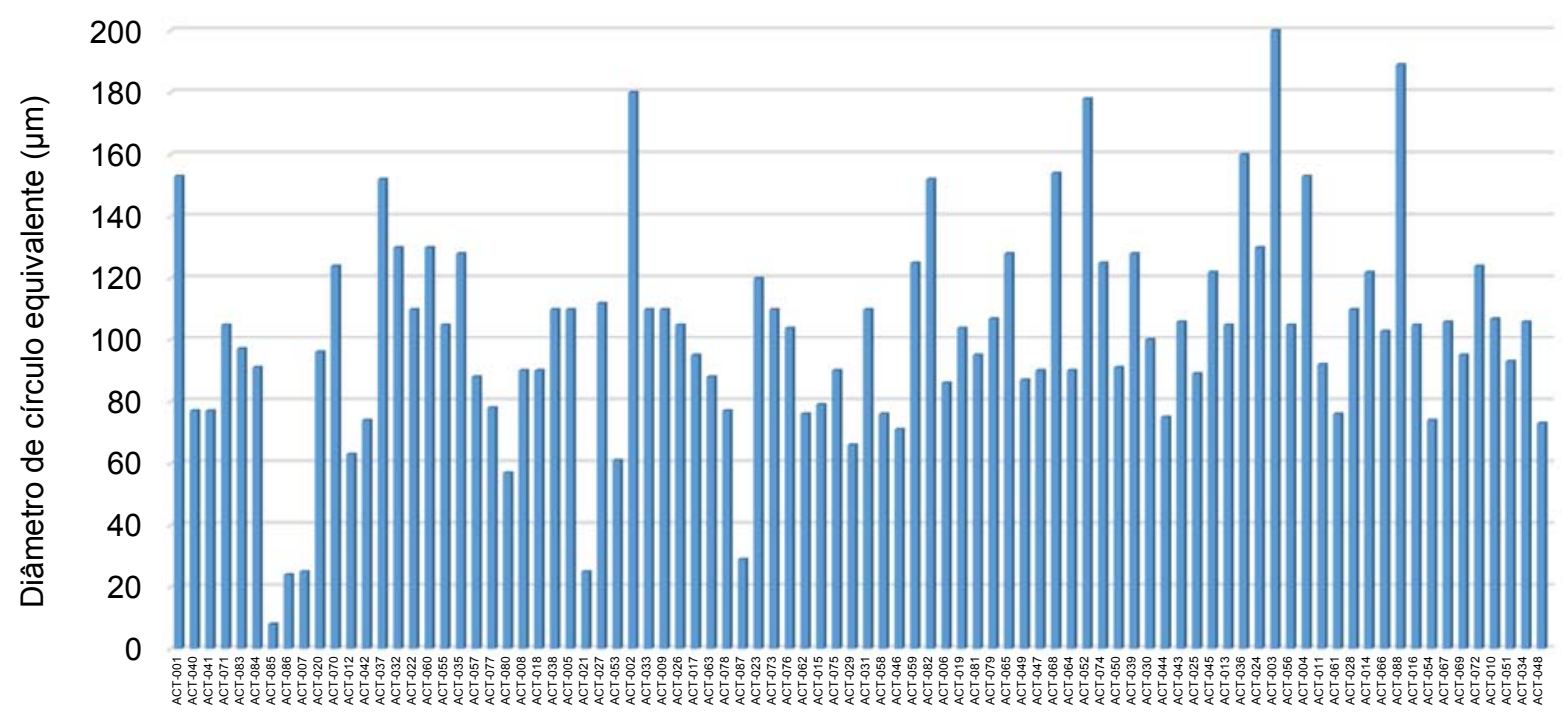

Os clusters de sulfetos apresentam uma mediana na distribuição dos tamanhos entre 80 e $100 \mu \mathrm{m}$, próximo ao diâmetro da alimentação da flotação ( $P_{80}$ de $106 \mu \mathrm{m}$ ). Algumas amostras apresentam mediana de distribuição de tamanho superior a 160 $\mu \mathrm{m}$ (ACT-002, 003, 052 e 083). Por outro lado, as amostras ACT-085 e 086 apresentam medianas abaixo de $20 \mu \mathrm{m}$.

4.2.8 Associações dos grãos de ouro por perímetro de contato

As associações dos grãos de ouro foram definidas por meios de seus perímetros de contato em termos de perímetro exposto, não encapsulado e incluso conforme discussões do item 3.4 "Cálculos das associações de perímetro de contato dos grãos de ouro".

Estes resultados são apresentados no Apêndice 8 e detalhados em termos de associações mineralógicas com sulfetos e demais minerais (ouro não encapsulado e incluso) no Apêndice 9. Comparativamente estes resultados são apresentados na Figura 4.19 e Figura 4.20; já a Tabela 4.2 apresenta os valores médios de associações de perímetro dos grãos de ouro com sulfetos e minerais de ganga para o conjunto de amostras estudados (ouro não encapsulado e ouro incluso). 
Figura 4.19 - Associação dos grãos de ouro por perímetro de contato - acessível, não encapsulado e incluso (produto afundado, fração $-0,50+0,020 \mathrm{~mm}$ )

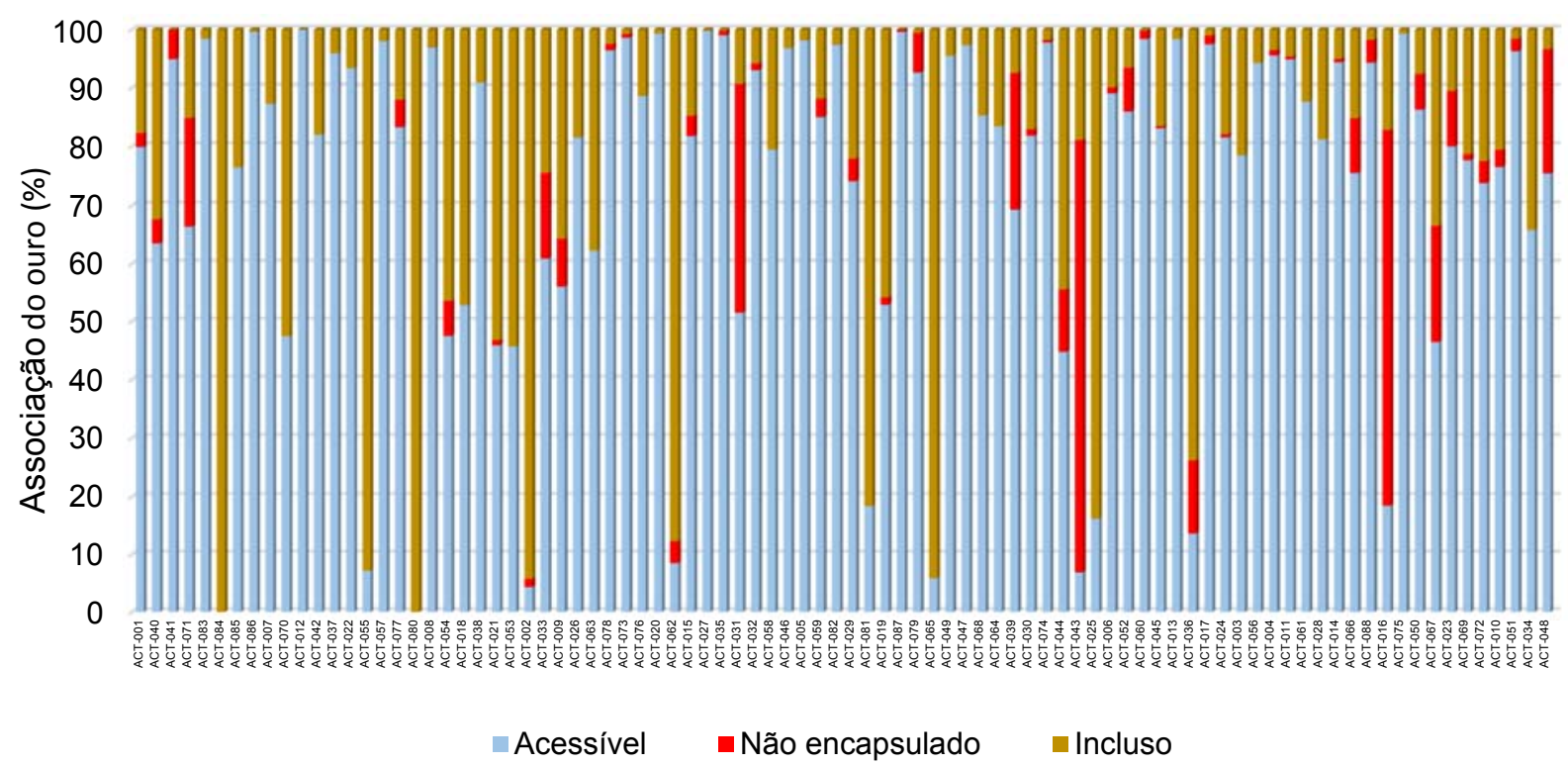

Figura 4.20 - Associação dos grãos de ouro por perímetro de contato (produto afundado, fração $-0,50+0,020 \mathrm{~mm}$ )

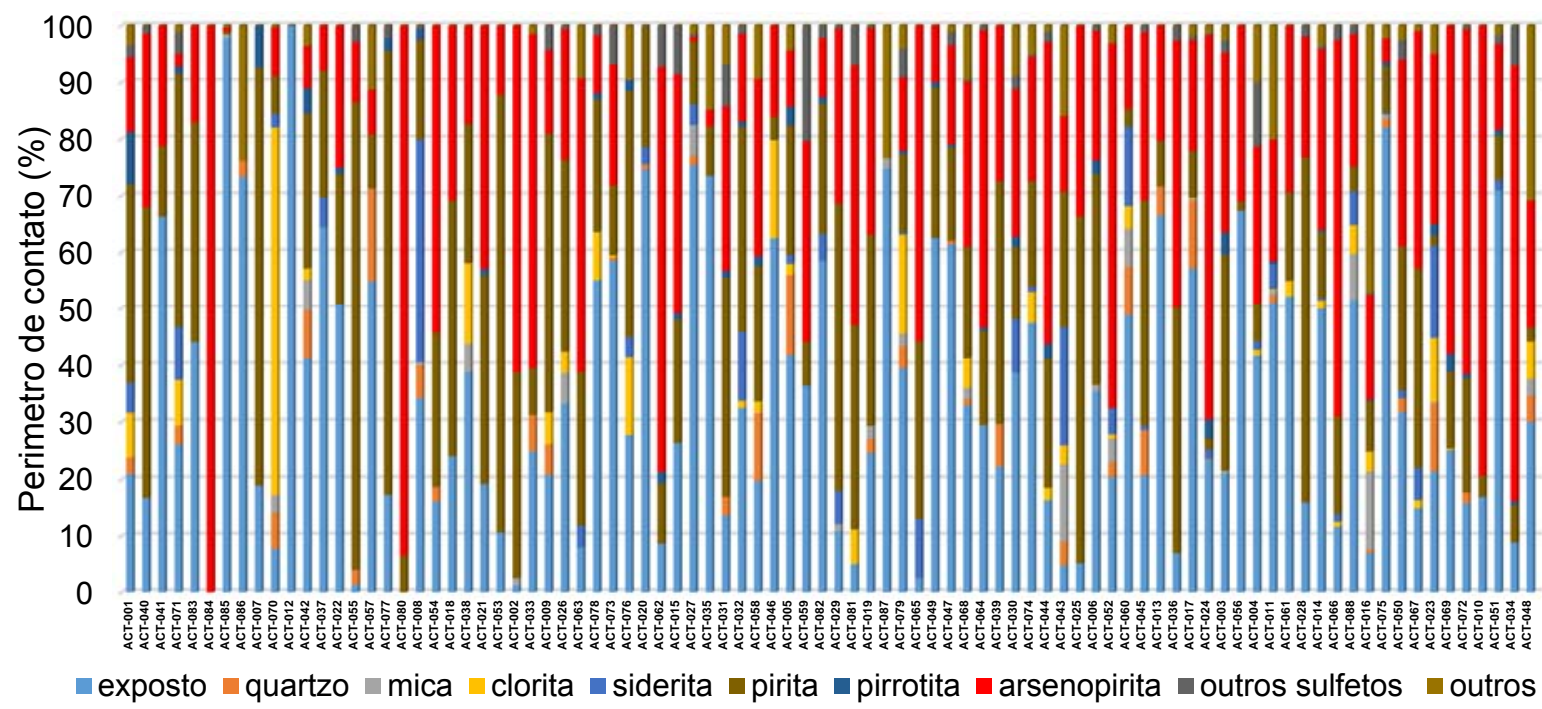

Outros: albita, anquerita, ilmenita, rutilo, goethita, zircão, cromita, monazita, $\mathrm{FeAsO}$, AlFe-PbAsO, apatita. 
Tabela 4.2 - Sumário das associações dos grãos de ouro por perímetro de contato (produto afundado, fração $-0,50+0,020 \mathrm{~mm}$ )

\begin{tabular}{|c|c|c|c|c|c|c|c|c|c|c|c|c|}
\hline & \multirow{2}{*}{$\begin{array}{c}\text { Exposto } \\
(\%)\end{array}$} & \multicolumn{7}{|c|}{ Não encapsulado (\%) } & \multicolumn{4}{|c|}{ Incluso (\%) } \\
\hline & & total & pirita & arsenopirita & quartzo & clorita & anq+sid & outros & total & pirita & arsenopirita & outros \\
\hline media & 73 & 5,6 & 0,4 & 0,4 & 1,3 & 1,1 & 0,3 & 2,2 & 21 & 11 & 10 & 0,5 \\
\hline $\max$ & 100 & 74 & 11 & 8 & 15 & 17 & 11 & 62 & 100 & 88 & 100 & 13 \\
\hline $\min$ & $<1$ & $<1$ & $<1$ & $<1$ & $<1$ & $<1$ & $<1$ & $<1$ & $<1$ & $<1$ & $<1$ & $<1$ \\
\hline
\end{tabular}

anq+sid: anquerita + siderita; max: máximo e min: mínimo

Outros: albita, anquerita, ilmenita, rutilo, goethita, zircão, cromita, monazita, $\mathrm{FeAsO}, \mathrm{Au}, \mathrm{AlFe}-\mathrm{PbAsO}$, apatita.

Para as condições de cominuição empregadas, verifica-se que parcela expressiva de ouro apresenta alguma exposição de perímetro de grãos (2D) - em média 73\%.

ouro incluso está essencialmente associado a pirita e arsenopirita e representa em média $21 \%$ do total dos grãos de ouro, sendo que apenas em 14 amostras o ouro incluso representa mais de $40 \%$, sete das quais com mais de $70 \%$ de ouro incluso (ACT-002, 025, 036, 055, 065, 080 e 084).

De maneira geral a parcela de ouro não encapsulado (intersticial - em contato com duas ou mais espécies minerais) é pouco relevante, em média 5,6\%; somente em 10 amostras esta forma de associação do ouro é superior a 15\%, destacando-se as amostras ACT-016 (64\% - outros: albita, anquerita, ilmenita, rutilo, goethita, zircão, monazita, FeAsO, AlFe-PbAsO, apatita), 031 (39\% - quartzo e clorita), 036, 043 (74\% - outros), 048, 065, 067,070, 072 e 081

\subsubsection{Formas de ocorrência e estimativa da composição de ouro}

Os aspectos texturais do ouro observados em relação à sua forma de ocorrência e associações com a ganga presente foram avaliados por microscopia eletrônica de varredura por meio de imagens de elétrons retroespalhados (contraste de número atômico) associadas a microanálises por EDS. A Fotomicrografia 4.1 ilustra as principais feições verificadas e a composição química das fases assim como os Anexos 10, 11 e 12. 
Fotomicrografia 4.1 - Detalhe de grãos de ouro observados no MEV/EDS - produto afundado, fração $-0,50+0,020 \mathrm{~mm}$
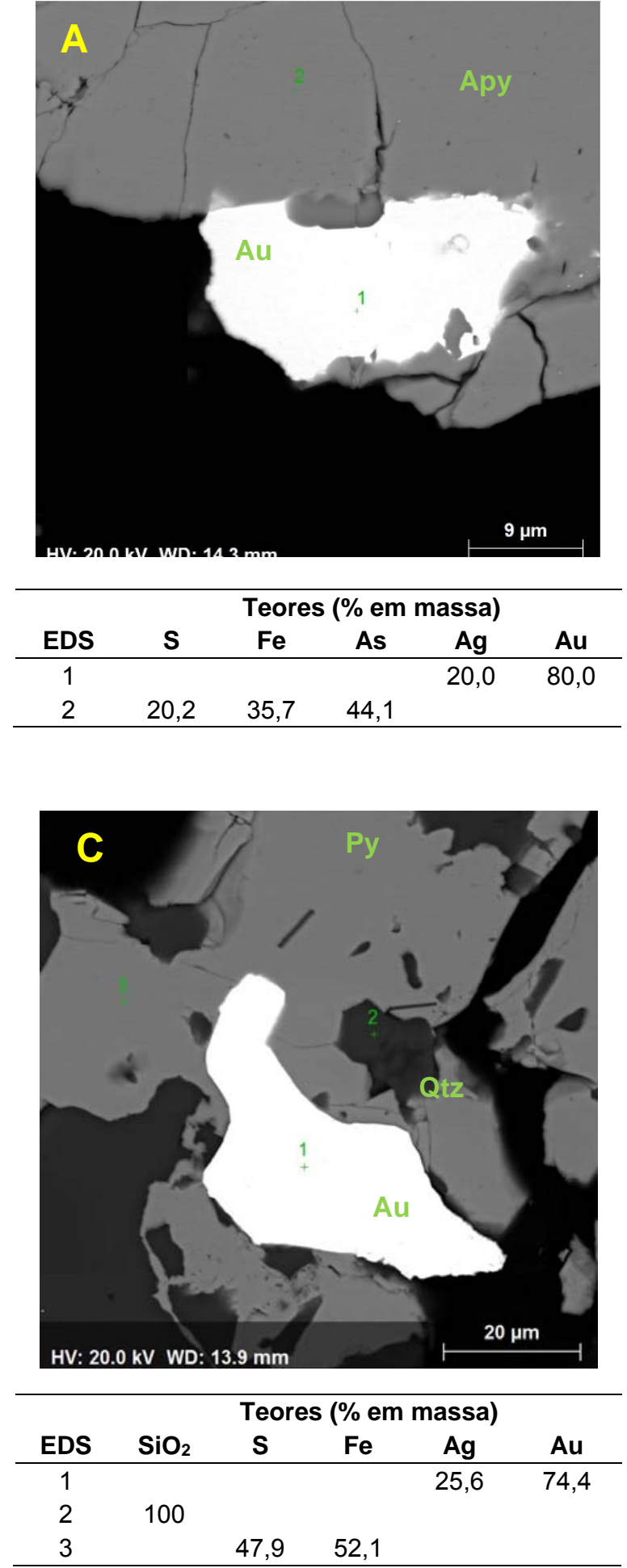

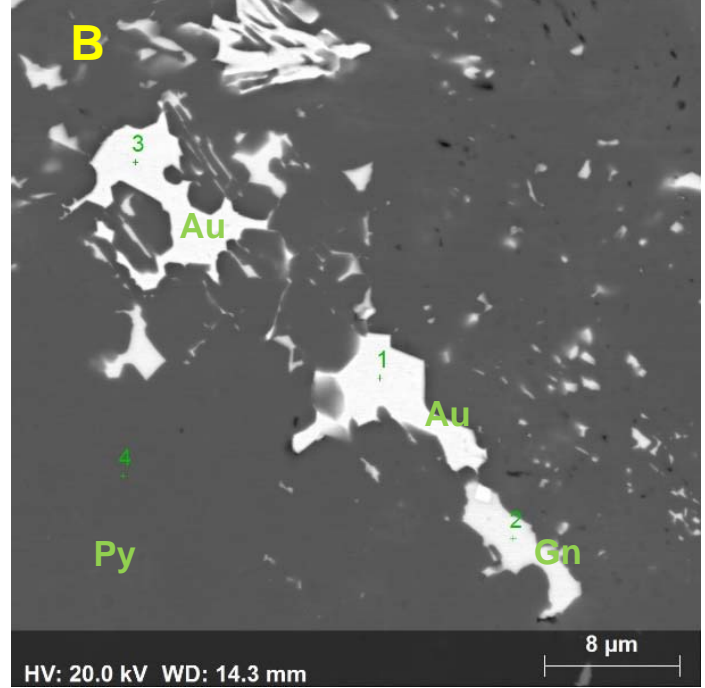

\begin{tabular}{cccccc}
\hline & \multicolumn{5}{c}{ Teores (\% em massa) } \\
EDS & $\mathbf{S}$ & $\mathbf{F e}$ & $\mathbf{A g}$ & $\mathbf{A u}$ & $\mathbf{P b}$ \\
\hline 1 & & & 23,4 & 76,6 & \\
2 & 11,2 & & & & 88,8 \\
3 & & & 24,5 & 75,5 & \\
4 & 49,9 & 50,1 & & & \\
\hline
\end{tabular}

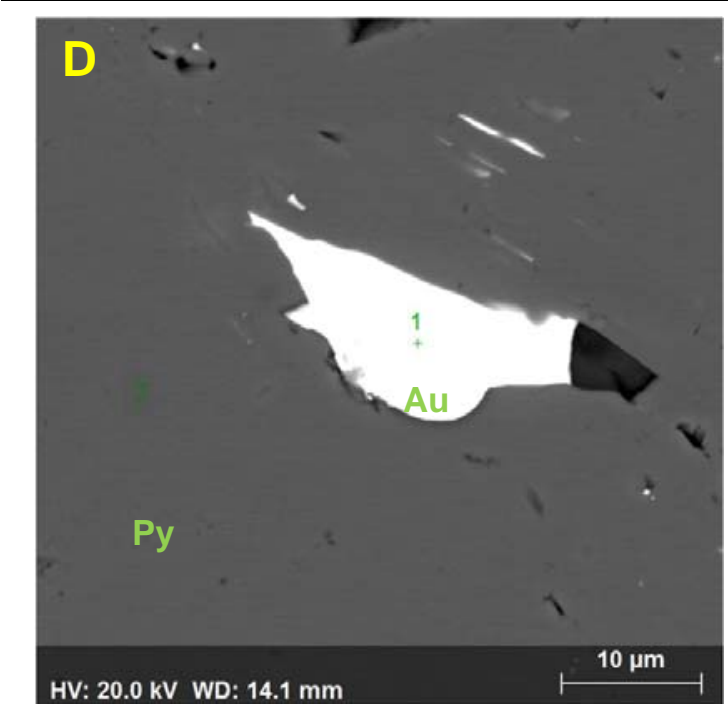

Teores (\% em massa)

\begin{tabular}{|c|c|c|c|c|c|c|}
\hline EDS & MgO & $\mathrm{Fe}_{2} \mathrm{O}_{3}$ & $\mathrm{~s}$ & $\mathrm{Fe}$ & $\mathrm{Ag}$ & $\mathrm{Au}$ \\
\hline 1 & & & & & 39,0 & 61,0 \\
\hline 2 & & & 47,7 & 52,3 & & \\
\hline
\end{tabular}

Obs: py: pirita; Au: ouro; qtz: quartzo; Gn: galena; Apy: arsenopirita

A Fotomicrografia 4.1-A mostra a associação do ouro com arsenopirita (ponto 2) na qual o ouro se apresenta como parcialmente exposto (aproximadamente $40 \%$ exposto 
e 60\% associado arsenopirita). A Fotomicrografia 4.1-B, os grãos de ouro (pontos 1 e 3) ocorrem totalmente inclusos na pirita; note que a galena (ponto 2) apresenta tom de cinza pouco inferior em relação ao ouro e que pequenos grãos de galena, inferiores a $8 \mu \mathrm{m}$ ocorrem dispersos na partícula de pirita. A Fotomicrografia 4.1-C apresenta grãos de ouro em contato com duas ou mais fases minerais de sulfetos e silicatos; pequenas lamelas inclusas podem ocorrer. Essa situação é classificada como ouro não encapsulado. Já a Fotomicrografia 4.1-D apresenta grãos de ouro incluso em pirita.

Por meio da análise pontual por MEV-EDS foi possível determinar a composição de ouro e prata; os grãos de ouro apresentam um teor médio de $76,9 \%$ de ouro e $23,1 \%$ de prata com um desvio padrão de 12,7\% (Figura 4.21; 742 grãos analisados).

Figura 4.21 - Composição média estimada dos grãos de ouro

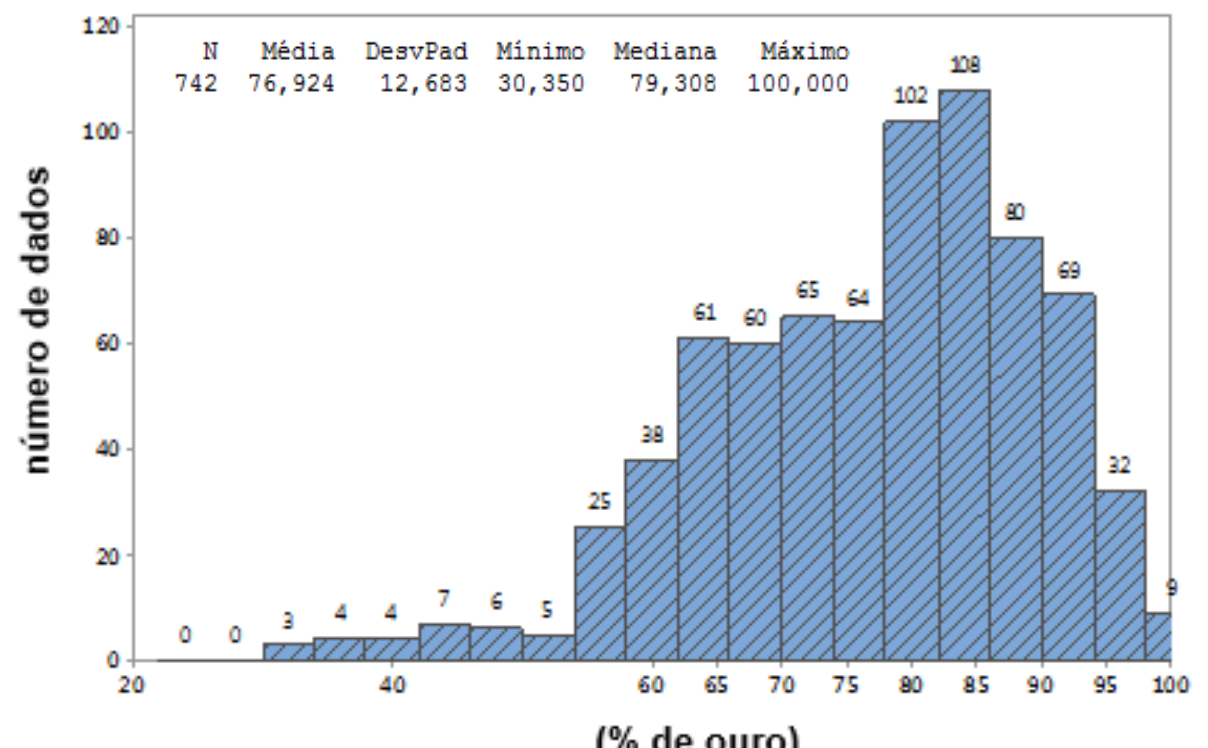

(\% de ouro)

Obs: N: numero de amostras; DesvPad: desvio padrão.

A Figura 4.22 apresenta a composição média dos grãos de ouro versus o seu diâmetro D50 e D90. A variância em torno da média para cada amostra aponta que não há uma relação direta entre composição e o diâmetro dos grãos de ouro. 
Figura 4.22 - Composição média estimada dos grãos de ouro e sua relação com o diâmetro de círculo equivalente do ouro

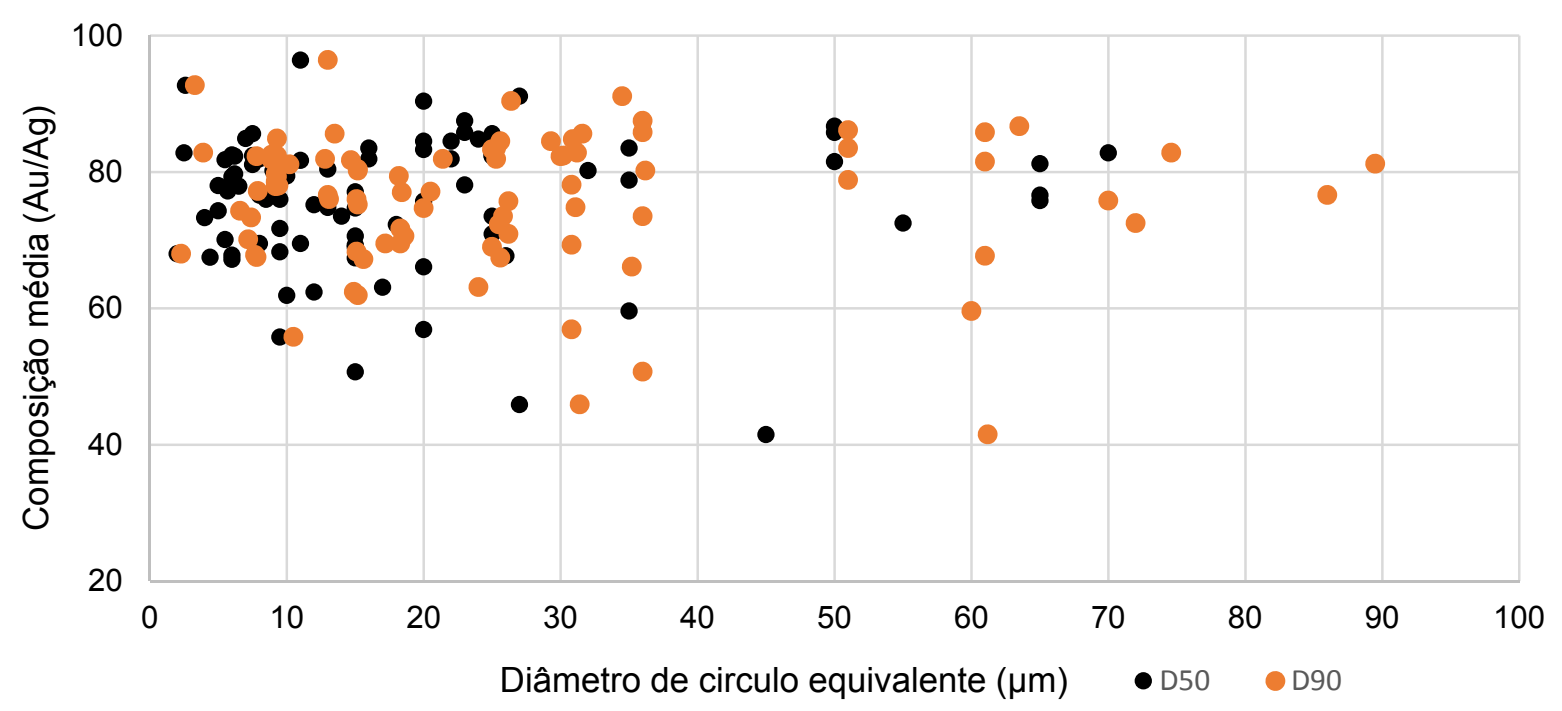




\section{DISCUSSÃO DOS RESULTADOS}

Neste capítulo são discutidos a análise granuloquímica, a relação de partículas analisadas e grãos de ouro e associação com sulfetos, tamanho de grãos de ouro e sulfetos, associação do ouro e estimativa da distribuição do ouro nas amostras.

\subsection{AGRUPAMENTO POR TEOR DE ARSÊNIO}

O agrupamento das amostras foi efetuado a partir das composições químicas em relação ao seu conteúdo de arsênio. A Figura 4.14, apresentada no capítulo anterior, mostra uma tendência de incremento no conteúdo de arsenopirita (ACT-007 ao 048) e diminuição de pirita com o crescimento dos teores de As nas amostras.

A relação das amostras por classe de minério definidas em relação ao seu conteúdo de arsênio em intervalos de 1000 em 1000 ppm é apresentada na Tabela 5.1. Foram classificadas ao todo 88 amostras de diferentes áreas do depósito em um total de seis grupos.

Excluindo-se a classe de material intemperizado verifica-se que menos de $15 \%$ das amostras apresentaram comportamento diverso, conforme já assinalado no capítulo anterior, devido principalmente à sua especificidade quanto ao local de coleta (zona cloritizada e/ou de baixo potencial econômico (abaixo de cut off). Dessa maneira, essas amostras foram consideradas dentro dos intervalos de arsênio acima citados, sendo agrupadas conforme as características químicas de cada classe de arsênio. 
Tabela 5.1 - Relação das amostras classificadas

\begin{tabular}{|c|c|c|c|c|}
\hline \multicolumn{5}{|c|}{ Arsênio abaixo de 1000 ppm } \\
\hline ACT-002 & ACT-012 & ACT-026 & ACT-042 & ACT-057 \\
\hline ACT-007 & ACT-018 & ACT-033 & ACT-053 & ACT-070 \\
\hline ACT-008 & ACT-021 & ACT-037 & ACT-054 & ACT-077 \\
\hline ACT-009 & ACT-022 & ACT-038 & ACT-055 & ACT-080 \\
\hline \multicolumn{5}{|c|}{ Arsênio entre 1000 e 2000 ppm } \\
\hline ACT-005 & ACT-031 & ACT-058 & ACT-073 & \\
\hline АCT-015 & ACT-032 & ACT-059 & ACT-076 & \\
\hline ACT-020 & ACT-035 & ACT-062 & ACT-078 & \\
\hline ACT-027 & ACT-046 & ACT-063 & & \\
\hline \multicolumn{5}{|c|}{ Arsênio entre 2000 e 3000 ppm } \\
\hline ACT-006 & ACT-030 & ACT-048 & ACT-065 & ACT-082 \\
\hline ACT-087 & ACT-039 & ACT-049 & ACT-068 & \\
\hline ACT-019 & ACT-043 & ACT-051 & ACT-079 & \\
\hline ACT-029 & ACT-047 & ACT-064 & ACT-081 & \\
\hline \multicolumn{5}{|c|}{ Arsênio entre 3000 e 4000 ppm } \\
\hline ACT-013 & ACT-052 & ACT-036 & & \\
\hline ACT-017 & ACT-060 & & & \\
\hline АCT-044 & АCT-074 & & & \\
\hline ACT-045 & ACT-025 & & & \\
\hline \multicolumn{5}{|c|}{ Arsênio acima de 4000 ppm } \\
\hline ACT-003 & ACT-014 & ACT-034 & ACT-066 & ACT-075 \\
\hline АCT-004 & ACT-023 & ACT-050 & ACT-067 & ACT-016 \\
\hline АCT-010 & АCT-024 & ACT-056 & АCT-069 & ACT-081 \\
\hline ACT-011 & ACT-028 & ACT-061 & ACT-072 & \\
\hline \multicolumn{5}{|l|}{ Intemperizada } \\
\hline ACT-083 & ACT-040 & & & \\
\hline ACT-084 & ACT-041 & & & \\
\hline ACT-085 & АCT-001 & & & \\
\hline ACT-086 & ACT-071 & & & \\
\hline
\end{tabular}

\subsection{CLASSIFICAÇÃO POR PENEIRAMENTO EM 0,020 MM}

5.2.1 Análise granulométrica e separações minerais

A distribuição de massa, teores e distribuições de $A u$, As e $S$ para produtos da classificação em $0,020 \mathrm{~mm}$ médios para as classes de amostras definidas no item 5.1 estão expostas Tabela 5.2 . 
Os resultados obtidos indicam que em cerca de $70-75 \%$ em massa, 95 a $98 \%$ do Au estão contidos acima de 0,020 mm para as condições de moagem empregadas. Para o material intemperizado, a distribuição em massa para a fração acima de 0,020 mm representa $47 \%$ da massa e $87 \%$ do $\mathrm{Au}$.

Os teores de ouro para a fração retida em 0,020 mm nas classes abaixo de 4000 ppm de arsênio estão entre 0,955 e 1,74 ppm, incluído as amostras intemperizadas. Para a classe acima de 4000 ppm tem-se um salto nos teores de ouro e arsênio (3,95 ppm de ouro e 9973 ppm de arsênio).

Tabela 5.2 - Análise granulométrica, teores e distribuição de ouro, arsênio e enxofre para as classes de minério

\begin{tabular}{|c|c|c|c|c|c|c|c|}
\hline \multirow{2}{*}{ Fração (mm) } & \multirow{2}{*}{$\begin{array}{c}\text { massa } \\
(\%)\end{array}$} & \multicolumn{3}{|c|}{ Teores } & \multicolumn{3}{|c|}{ Distribuição (\%) } \\
\hline & & $\mathrm{Au}(\mathrm{ppm})$ & As (ppm) & $\mathrm{S}(\%)$ & $\mathrm{Au}$ & As & $\mathbf{S}$ \\
\hline \multicolumn{8}{|l|}{ Intemperizada } \\
\hline$-0,50+0,020$ & 46,8 & 0,955 & 1856 & 1,64 & 87,3 & 85,4 & 86,1 \\
\hline$-0,020$ & 53,2 & 0,123 & 280 & 0,23 & 12,7 & 14,6 & 13,9 \\
\hline total calculado & 100,0 & 0,740 & 1313 & 1,11 & 100,0 & 100,0 & 100,0 \\
\hline \multicolumn{8}{|l|}{ Arsênio > 1000 ppm } \\
\hline$-0,50+0,020$ & 73,2 & 1,06 & 967 & 2,60 & 96,3 & 78,0 & 91,6 \\
\hline$-0,020$ & 26,8 & 0,112 & 746 & 0,65 & 3,73 & 22,0 & 8,36 \\
\hline total calculado & 100,0 & 0,808 & 908 & 2,07 & 100,0 & 100,0 & 100,0 \\
\hline \multicolumn{8}{|l|}{ Arsênio 1000 - 2000 ppm } \\
\hline$-0,50+0,020$ & 72,3 & 1,07 & 1236 & 2,63 & 95,0 & 79,1 & 91,8 \\
\hline$-0,020$ & 27,7 & 0,149 & 851 & 0,61 & 5,0 & 20,9 & 8,20 \\
\hline total calculado & 100,0 & 0,821 & 1129 & 2,07 & 100,0 & 100,0 & 100,0 \\
\hline \multicolumn{8}{|l|}{ Arsênio 2000 - 3000 ppm } \\
\hline$-0,50+0,020$ & 71,2 & 1,21 & 2237 & 1,88 & 93,2 & 77,5 & 91,3 \\
\hline$-0,020$ & 28,8 & 0,220 & 1601 & 0,44 & 6,84 & 22,5 & 8,69 \\
\hline total calculado & 100,0 & 0,925 & 2054 & 1,46 & 100,0 & 100,0 & 100,0 \\
\hline \multicolumn{8}{|l|}{ Arsênio 3000 - 4000 ppm } \\
\hline$-0,50+0,020$ & 73,2 & 1,74 & 2699 & 2,90 & 98,3 & 62,3 & 93,0 \\
\hline$-0,020$ & 26,8 & 0,084 & 4455 & 0,59 & 1,74 & 37,7 & 6,95 \\
\hline total calculado & 100,0 & 1,30 & 3170 & 2,28 & 100,0 & 100,0 & 100,0 \\
\hline \multicolumn{8}{|l|}{ Arsênio > 4000 ppm } \\
\hline$-0,50+0,020$ & 72,5 & 3,95 & 9973 & 2,42 & 95,4 & 86,6 & 81,2 \\
\hline$-0,020$ & 27,5 & 0,502 & 4054 & 1,48 & 4,60 & 13,4 & 18,8 \\
\hline total calculado & 100,0 & 3,00 & 8346 & 2,16 & 100,0 & 100,0 & 100,0 \\
\hline
\end{tabular}




\subsection{SEPARAÇÕES MINERAIS POR LÍQUIDOS DENSOS}

A distribuição de massa, teores e distribuições de $\mathrm{Au}$, As e $\mathrm{S}$ para produtos flutuados e afundados médios para as classes de amostras definidas no item 5.1 estão expostas na Tabela 5.3.

Tabela 5.3 - Sumário comparativo das separações minerais por liquido denso (TBE $2,95 \mathrm{~g} / \mathrm{cm}^{3}$ )

\begin{tabular}{|c|c|c|c|c|c|c|c|c|c|c|c|}
\hline \multirow{2}{*}{ Fração (mm) } & \multirow{2}{*}{ Produto } & \multirow{2}{*}{$\begin{array}{c}\text { massa } \\
\text { do } \\
\text { ensaio } \\
(\%)\end{array}$} & \multicolumn{3}{|c|}{ Teores } & \multicolumn{3}{|c|}{$\begin{array}{l}\text { Distribuição no } \\
\text { ensaio (\%) }\end{array}$} & \multicolumn{3}{|c|}{$\begin{array}{l}\text { Distribuição na } \\
\text { amostra (\%) }\end{array}$} \\
\hline & & & $\begin{array}{c}\mathrm{Au} \\
(\mathrm{ppm})\end{array}$ & $\begin{array}{c}\text { As } \\
(p p m)\end{array}$ & S (\%) & $\mathrm{Au}$ & As & $\mathbf{s}$ & $\mathrm{Au}$ & As & $\mathbf{S}$ \\
\hline \multicolumn{12}{|l|}{ Intemperizada } \\
\hline \multirow[t]{2}{*}{$-0,50+0,020$} & afundado & 14,3 & 5,36 & 9863 & 11,1 & 80,2 & 75,8 & 97,0 & 70,0 & 64,8 & 83,6 \\
\hline & flutuado & 85,7 & 0,221 & 523 & 0,06 & 19,8 & 24,2 & 2,98 & 17,3 & 20,6 & 2,57 \\
\hline total calculado & & 100,0 & 0,955 & 1856 & 1,64 & 100,0 & 100,0 & 100,0 & 87,3 & 85,4 & 86,1 \\
\hline \multicolumn{12}{|c|}{ Arsênio > 1000 ppm } \\
\hline \multirow[t]{2}{*}{$-0,50+0,020$} & afundado & 12,1 & 7,75 & 4369 & 20,7 & 88,3 & 54,7 & 96,6 & 85,0 & 42,6 & 88,5 \\
\hline & flutuado & 87,9 & 0,142 & 499 & 0,10 & 11,7 & 45,3 & 3,38 & 11,3 & 35,3 & 3,10 \\
\hline total calculado & & 100,0 & 1,063 & 967 & 2,60 & 100,0 & 100,0 & 100,0 & 96,3 & 78,0 & 91,6 \\
\hline \multicolumn{12}{|c|}{ Arsênio 1000 - 2000 ppm } \\
\hline \multirow[t]{2}{*}{$-0,50+0,020$} & afundado & 10,9 & 8,04 & 10179 & 23,4 & 81,1 & 89,6 & 96,8 & 77,1 & 70,9 & 88,8 \\
\hline & flutuado & 89,1 & 0,229 & 145 & 0,10 & 18,9 & 10,4 & 3,3 & 18,0 & 8,3 & 3,0 \\
\hline total calculado & & 100 & 1,078 & 1236 & 2,63 & 100,0 & 100,0 & 100,0 & 95,0 & 79,1 & 91,8 \\
\hline \multicolumn{12}{|c|}{ Arsênio 2000 - 3000 ppm } \\
\hline \multirow[t]{2}{*}{$-0,50+0,020$} & afundado & 13,1 & 7,96 & 13219 & 13,9 & 85,9 & 77,2 & 96,8 & 80,1 & 59,9 & 88,4 \\
\hline & flutuado & 86,9 & 0,196 & 585 & 0,07 & 14,0 & 22,7 & 3,21 & 13,1 & 17,6 & 2,93 \\
\hline total calculado & & 100,0 & 1,211 & 2237 & 1,88 & 100,0 & 100,0 & 100,0 & 93,2 & 77,5 & 91,3 \\
\hline \multicolumn{12}{|c|}{ Arsênio 3000 - 4000 ppm } \\
\hline \multirow[t]{2}{*}{$-0,50+0,020$} & afundado & 11,0 & 14,05 & 21682 & 25,7 & 88,7 & 88,3 & 97,4 & 87,1 & 55,0 & 90,7 \\
\hline & flutuado & 89,0 & 0,222 & 354 & 0,08 & 11,3 & 11,7 & 2,57 & 11,1 & 7,27 & 2,39 \\
\hline total calculado & & 100,0 & 1,742 & 2699 & 2,90 & 100,0 & 100,0 & 100,0 & 98,3 & 62,3 & 93,0 \\
\hline \multicolumn{12}{|c|}{ Arsênio > 4000 ppm } \\
\hline \multirow[t]{2}{*}{$-0,50+0,020$} & afundado & 10,9 & 33,60 & 71574 & 21,1 & 92,8 & 78,2 & 95,2 & 88,6 & 67,8 & 77,3 \\
\hline & flutuado & 89,1 & 0,317 & 2437 & 0,13 & 7,17 & 21,8 & 4,84 & 6,84 & 18,9 & 3,93 \\
\hline total calculado & & 100,0 & 3,94 & 9973 & 2,42 & 100,0 & 100,0 & 100,0 & 95,4 & 86,6 & 81,2 \\
\hline
\end{tabular}

Os teores médios de ouro nos produtos afundados variam entre 5,36 ppm e 33,6 ppm. Nas classes de material intemperizado e com teores inferiores a 3000 ppm de As os teores de Au junto ao afundado variam entre 5,6 e 8,4 ppm; acima deste teor de 
arsênio ocorre um salto passando para 14,1 ppm Au (3000-4000 ppm) e 33,6 ppm na classe acima de 4000 ppm.

As parcelas de ouro contido nos produtos afundados correspondem a 80,2 e 92,8\% no ensaio e, na amostra, cerca de $70 \%$ para o material intemperizado e de 77 a $89 \%$ para as demais, com os maiores valores para as classes acima 3000 ppm de As ( $>87 \%$ do Au no produto afundado).

\subsection{COMPOSIÇÃO MINERALÓGICA}

As identificações minerais efetuadas nas amostras (tal qual) pela discriminação entre as fases foi estabelecida através da análise em modo XBSE no sistema MLA. O conteúdo de sulfetos nas classes definidas é apresentado na Figura 5.1.

Figura 5.1 - Distribuição mineralógica dos sulfetos nas amostras - classes de teor de arsênio (\% massa; fração $-0,50+0,020 \mathrm{~mm}$ )

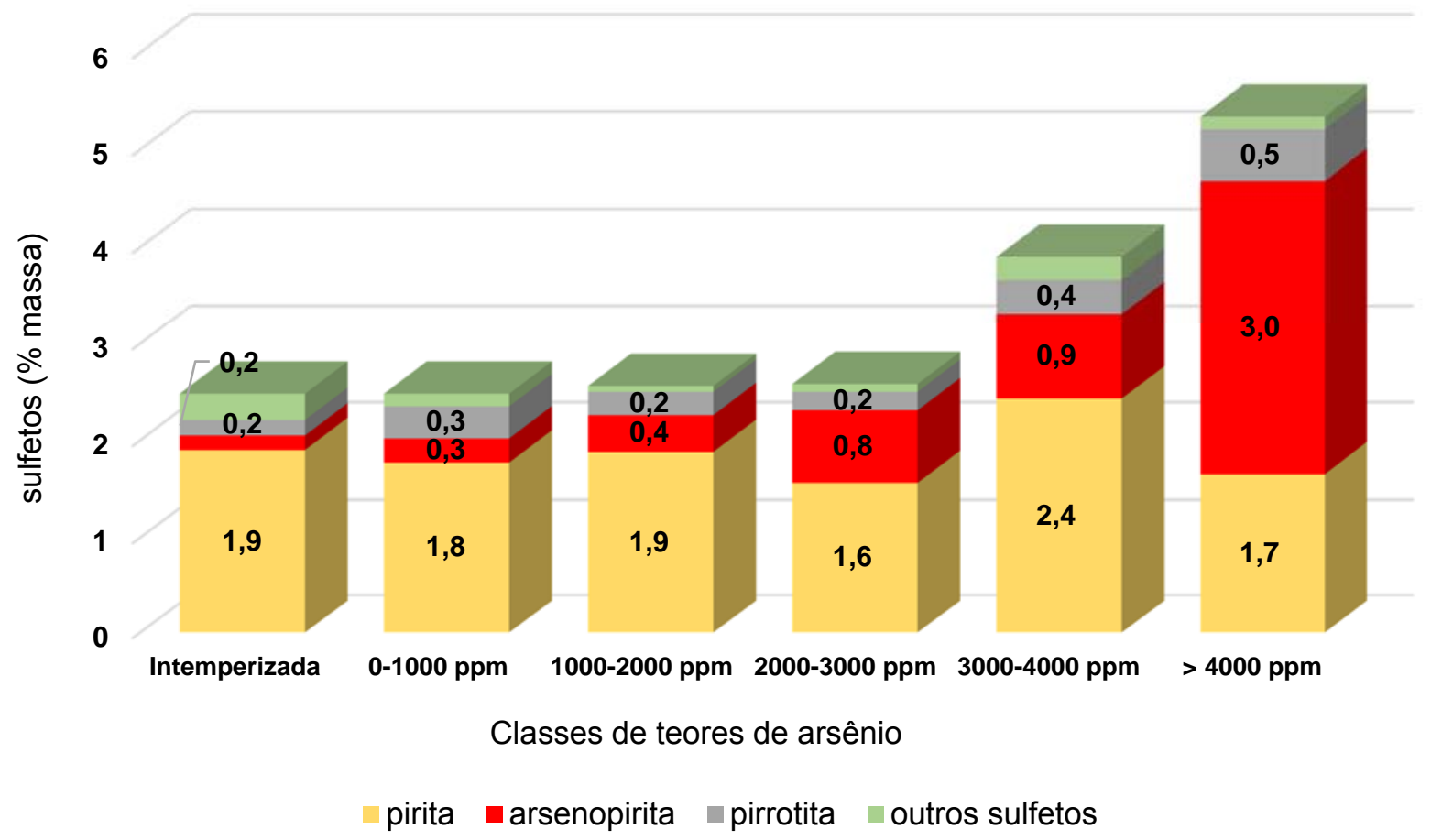

Outros sulfetos: calcopirita, esfalerita e galena.

O conteúdo médio total de sulfetos é praticamente o mesmo para o material intemperizado e para as classes com até 3000 ppm de As (cerca de 2,5\% em massa); a partir daí, os conteúdos de sulfetos aumentam expressivamente. Os outros sulfetos 
(calcopirita, esfalerita e galena) respondem por aproximadamente 0,2\% da massa total das massas.

Os conteúdos individuais dos principias sulfetos (pirita, pirrotita e arsenopirita) ao longo das várias classes mostram uma tendência de acréscimo no conteúdo de arsenopirita e pirrotita com ligeiro decréscimo na de pirita. Ocorre uma variação brusca no conteúdo de arsenopirita e da relação arsenopirita/pirita para a classe de arsênio acima de 4000 ppm; o teor médio de arsênio passa de 3170 (classe 3000-4000 ppm) para 8346 ppm.

\subsection{DISTRIBUIÇÃO DE ENXOFRE}

A estimativa da distribuição de enxofre dentre os minerais presentes para as classes definidas é sumariada na Figura 5.2.

Figura 5.2 - Distribuição de enxofre nos sulfetos - teores de arsênio por classe

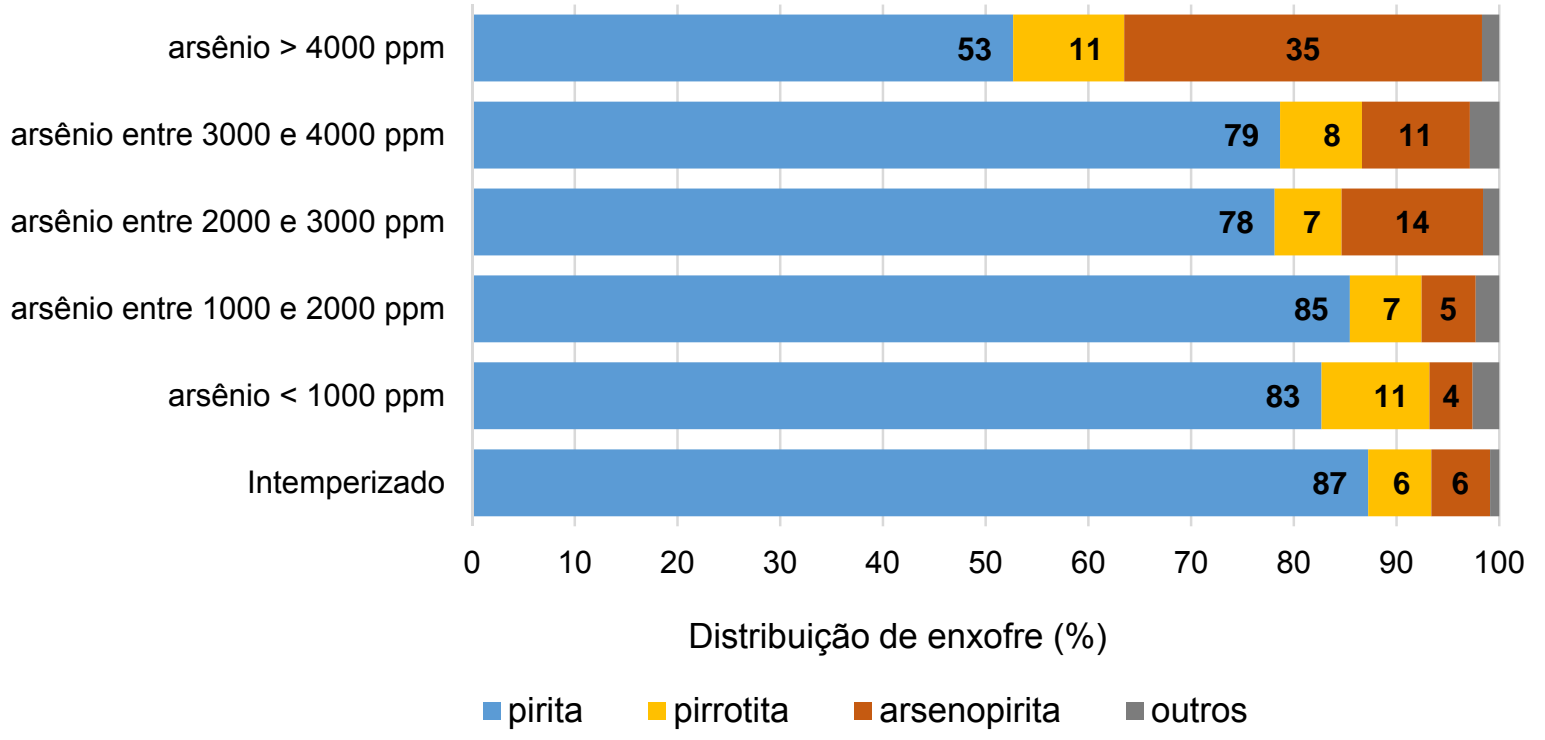

Outros: calcopirita, esfalerita e galena.

Cerca de 80 a $85 \%$ o enxofre está associado a pirita para as classes com teores de arsênio abaixo de 4000 ppm. A proporção relacionada à pirrotita é praticamente constante, à exceção da classe com As abaixo de 1000 ppm, em que este valor é um pouco mais elevado. Em relação ao enxofre associado à arsenopirita, nota-se valores 
bastante semelhantes para as classes abaixo de 2000 ppm de As com expressivo crescimento para aquelas com teores acima deste valor.

Para a faixa de arsênio $>4000$ ppm, a distribuição de enxofre é de $52 \%$ na pirita, $11 \%$ na pirrotita, $35 \%$ na arsenopirita e $2 \%$ em outros (calcopirita, esfalerita e galena). Esse aumento da distribuição de enxofre na arsenopirita é em decorrência do aumento do mineral na composição mineralógica, conforme observado na Figura 5.1, da seção anterior.

\subsection{TAMANHOS DOS GRÃOS DE OURO E DE SULFETOS}

A distribuição de tamanho dos grãos de ouro identificados pelo diâmetro de círculo equivalente das faixas de teor por arsênio é retratada na Figura 5.3.

Figura 5.3 - Distribuição acumulada abaixo - tamanho dos grãos de ouro por classe de teor de arsênio (\%)

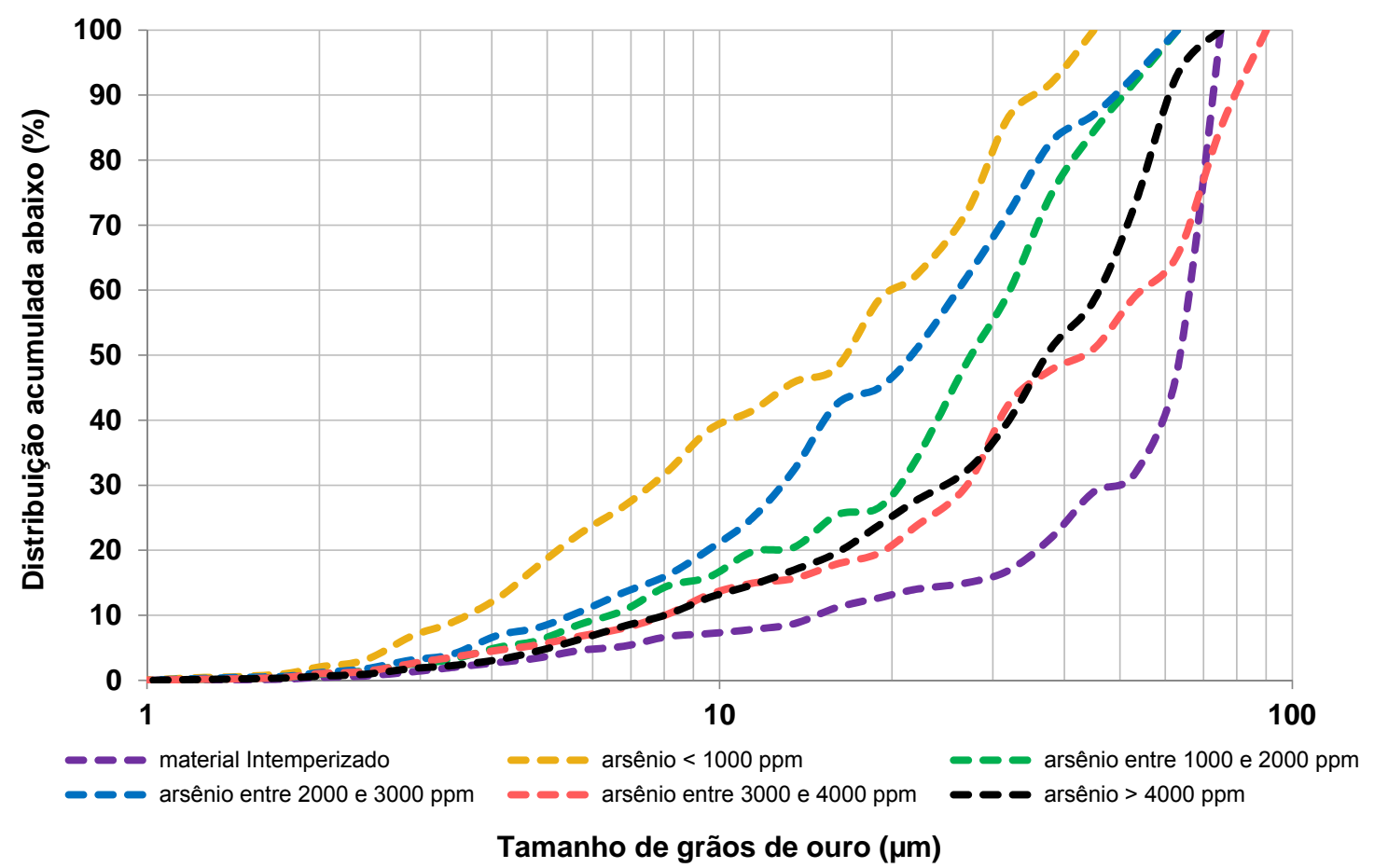

As distribuições acumuladas mostram que a classe de material intemperizado é aquela cujo grãos de ouro apresentam maior diâmetro médio (d50), $65 \mu \mathrm{m}$. No gráfico, é possível observar dois grupos com diâmetro médio semelhante; um grupo com d50 
variando de 17 a $29 \mu \mathrm{m}$ - amostras com teor de arsênio até 3000 ppm e um outro grupo com d $\mathrm{d}_{50}$ entre 39 a $42 \mu \mathrm{m}$ - amostras superiores a 3000 ppm de arsênio.

A distribuição granulométrica dos clusters de sulfetos e dos minerais portadores de enxofre minerais é apresentada na forma de curvas de distribuição acumulada na Figura 5.4, considerando o diâmetro de círculo equivalente.

Figura 5.4 - Distribuição granulométrica dos sulfetos por faixa de teor de arsênio fração $-0,5+0,020 \mathrm{~mm}$
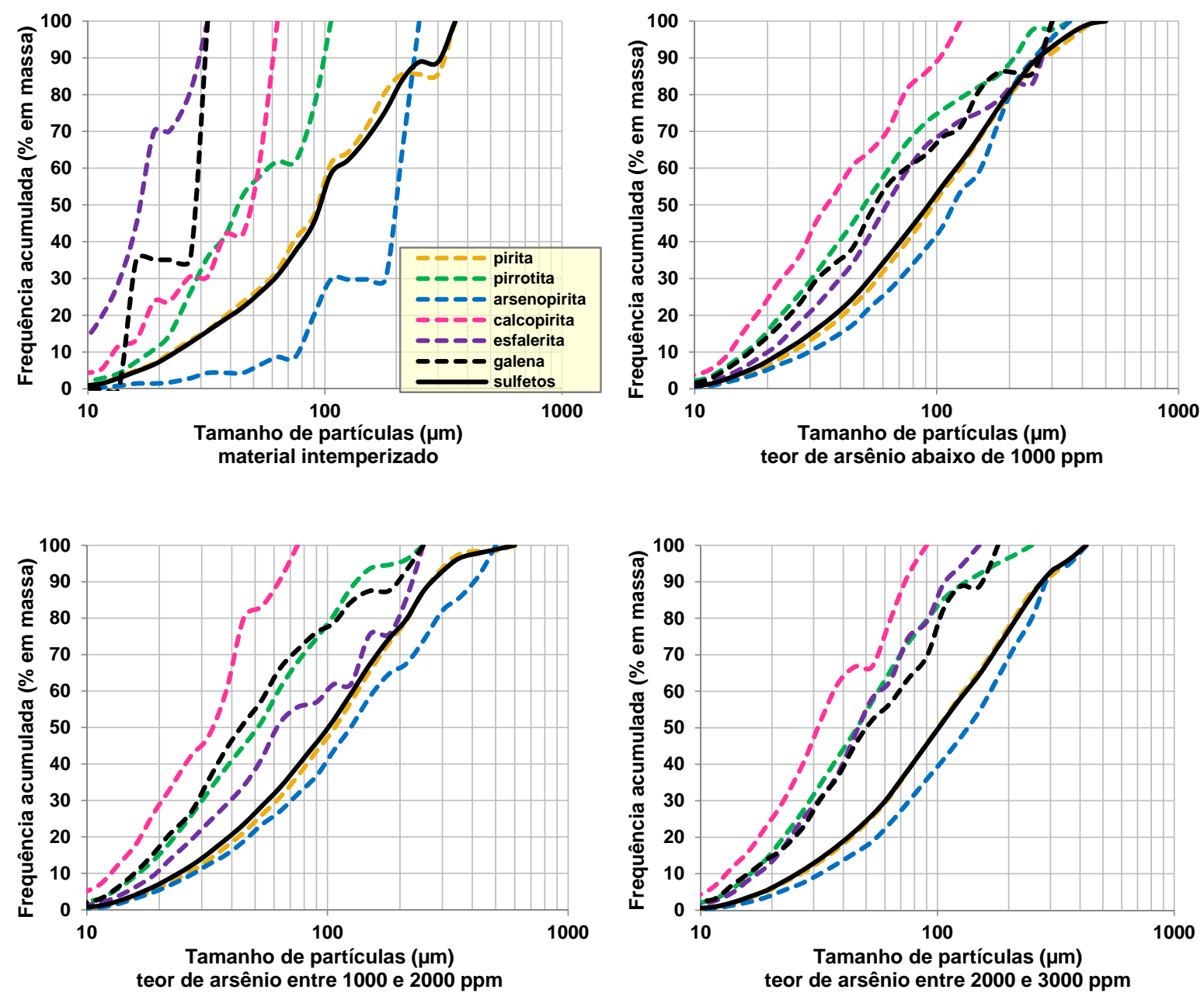

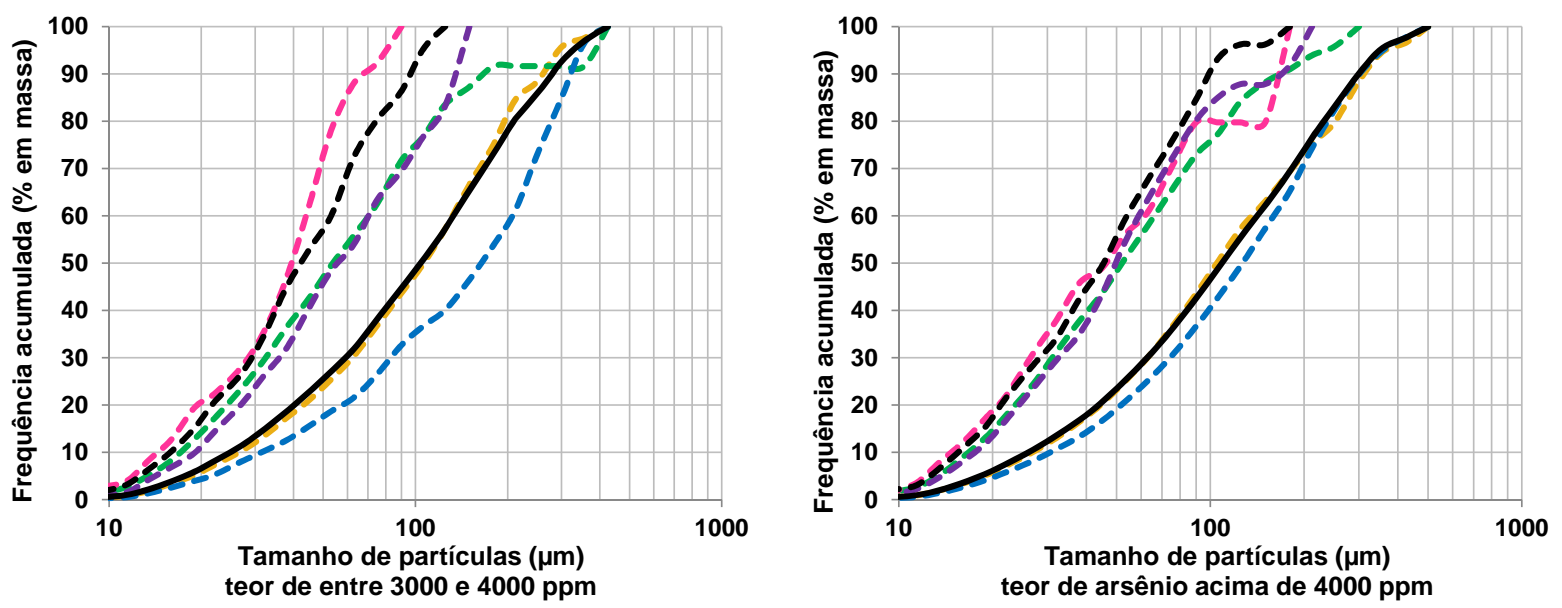

Verifica-se de modo recorrente em todas as classes, que a arsenopirita é o sulfeto que apresenta os maiores tamanhos de partículas, seguido pela pirita. Outro padrão a ser observado é a recorrência de finas partículas de calcopirita nas classes definidas por teores de arsênio.

A mediana da distribuição de tamanho dos sulfetos (global), da arsenopirita e da pirita

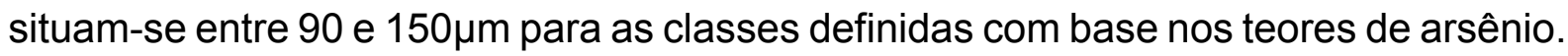
Para o material intemperizado, a menor quantidade de sulfetos responde por uma baixa estatística gerando curvas irregulares o que prejudica a análise das distribuições de tamanho.

\subsection{ASSOCIAÇÕES MINERAIS DE OURO E SULFETOS}

As associações dos grãos de ouro foram definidas através do perímetro de contato em:

- ouro exposto: parcela exposta do perímetro do grão;

- ouro associado: parcela do perímetro do grão associada a outro mineral (p. ex: arsenopirita, pirita e clorita).

Estes resultados são apresentados comparativamente para as classes definidas na Figura 5.5 e Tabela 5.4 .

As associações de perímetro de contato dos grãos de ouro nas classes definidas mostram que para teores mais elevados de As há um acréscimo na exposição dos 
grãos de ouro e maior associação com arsenopirita e, secundariamente, pirrotita; por outro lado, paralelamente tem-se um decréscimo na associação com pirita e clorita.

Figura 5.5 - Distribuição da associação mineral por perímetro de contato - associação do ouro com os principais minerais - fração $-0,50+0,020 \mathrm{~mm}$.

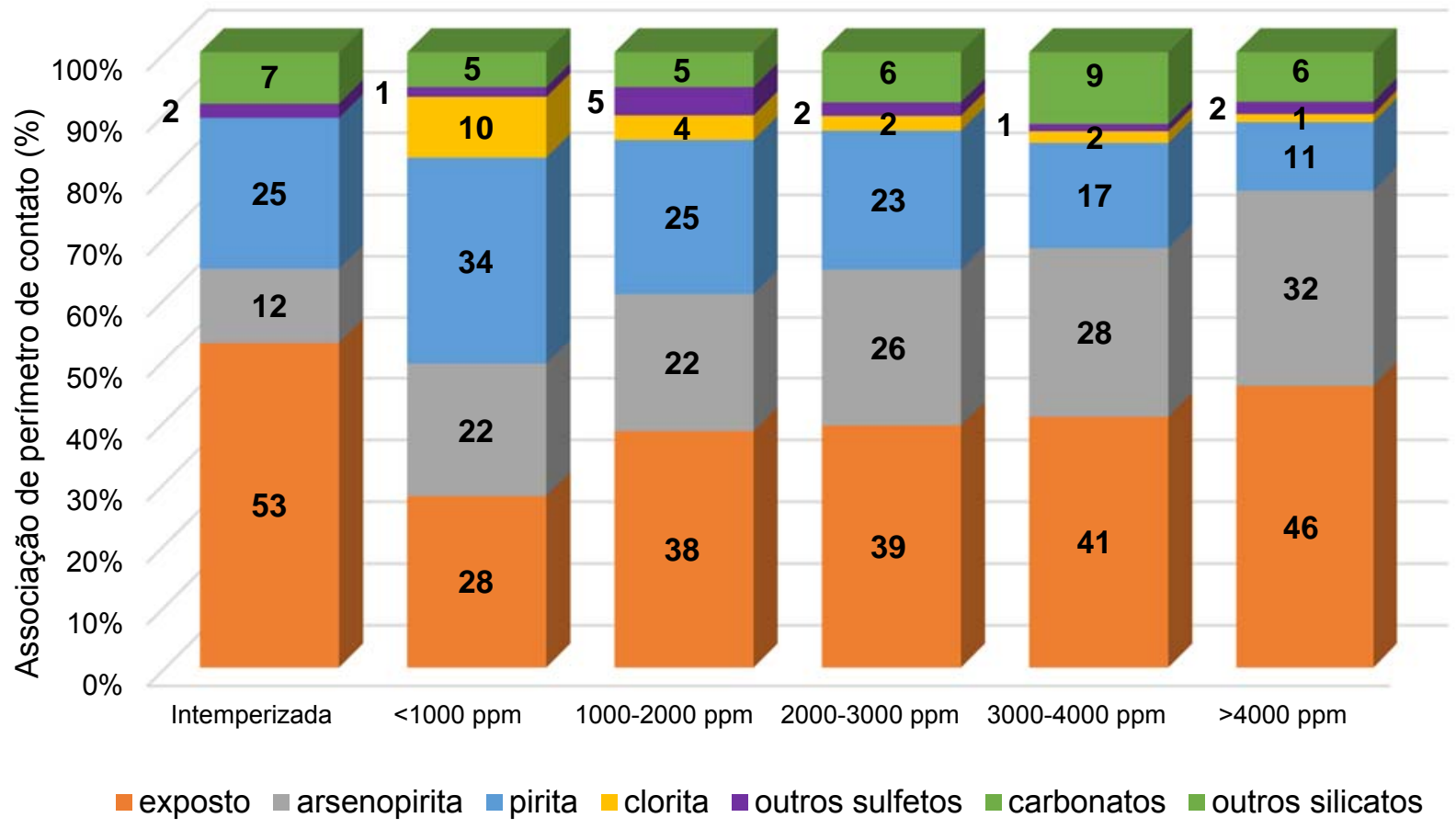

Legenda: outros sulfetos: pirrotita, calcopirita, esfalerita e galena; Carbonatos: anquerita e siderita; outros silicatos: quartzo, albita mica e outros (goethita foi incluída no grupo dos silicatos); outros: albita, anquerita, ilmenita, rutilo, goethita, zircão, cromita, monazita, $\mathrm{FeAsO}$, AlFe-PbAsO, apatita.

Tabela 5.4 - Associação mineral de grãos de ouro por perímetro de contato para as classes de minério (fração $-0,5+0,020 \mathrm{~mm}$ )

\begin{tabular}{|c|c|c|c|c|c|c|c|c|c|c|c|c|c|c|c|}
\hline & \multicolumn{15}{|c|}{ Associações (\% em perímetro de contato) } \\
\hline & $\exp$ & qtz & alb & mic & chl & gt & ank & sid & py & po & apy & cal & esf & gn & outros \\
\hline material Intemperizado & 52,7 & 1,1 & & 0,2 & & 4,3 & & 1,6 & 24,5 & 1,3 & 12,1 & 1,0 & & & 1,2 \\
\hline arsênio < 1000 ppm & 27,8 & 3,7 & & 1,2 & 9,9 & & & 0,5 & 33,6 & 0,9 & 21,5 & 0,6 & 0,1 & & 0,3 \\
\hline arsênio entre 1000 e 2000 ppm & 38,3 & 1,4 & 0,3 & 0,3 & 4,0 & 0,5 & & 1,0 & 25,0 & 1,3 & 22,4 & 1,8 & 1,5 & & 2,2 \\
\hline arsênio entre 2000 e 3000 ppm & 39,2 & 1,1 & & 1,0 & 2,4 & 3,4 & 0,1 & 1,8 & 22,5 & 0,9 & 25,5 & 0,7 & 0,4 & 0,2 & 0,8 \\
\hline arsênio entre 3000 e 4000 ppm & 40,6 & 6,2 & 0,4 & 1,0 & 1,9 & 0,4 & & 2,4 & 17,0 & 0,4 & 27,6 & 0,8 & & & 1,3 \\
\hline arsênio > 4000 ppm & 45,6 & 1,8 & 0,3 & 0,3 & 1,3 & 1,8 & & 2,2 & 11,1 & 1,1 & 31,9 & 0,2 & 0,4 & 0,3 & 1,7 \\
\hline
\end{tabular}

Legenda: exp: exposto; qtz: quartzo; alb: albita; mic: mica; chl: clorita; gt: goethita; ank: anquerita; sid: siderita; py: pirita; po: pirrotita; apy: arsenopirita; calc: calcopirita; esf: esfalerita e gn: galena.

Outros: albita, anquerita, ilmenita, rutilo, goethita, zircão, cromita, monazita, FeAsO, Au, AlFe-PbAsO, apatita. 
O ouro no material intemperizado apresenta particularidades em relação a sua exposição e associações de perímetro. Os grãos de ouro têm maiores dimensões e majoritariamente estão na forma exposta; verifica-se ainda menor associação com sulfetos $(38,9 \%)$, e maior parcela associada a goethita $(4,3 \%)$.

De forma semelhante ao apresentado para o ouro, a Figura 5.6 mostra o perímetro exposto dos sulfetos para a fração $-0,5+0,020 \mathrm{~mm}$. Observa-se uma tendência no aumento no grau de exposição das partículas de sulfetos conforme ocorre o aumento nos teores de arsênio.

Figura 5.6 - Perímetro exposto das partículas de sulfetos - fração -0,50+0,020 mm 100

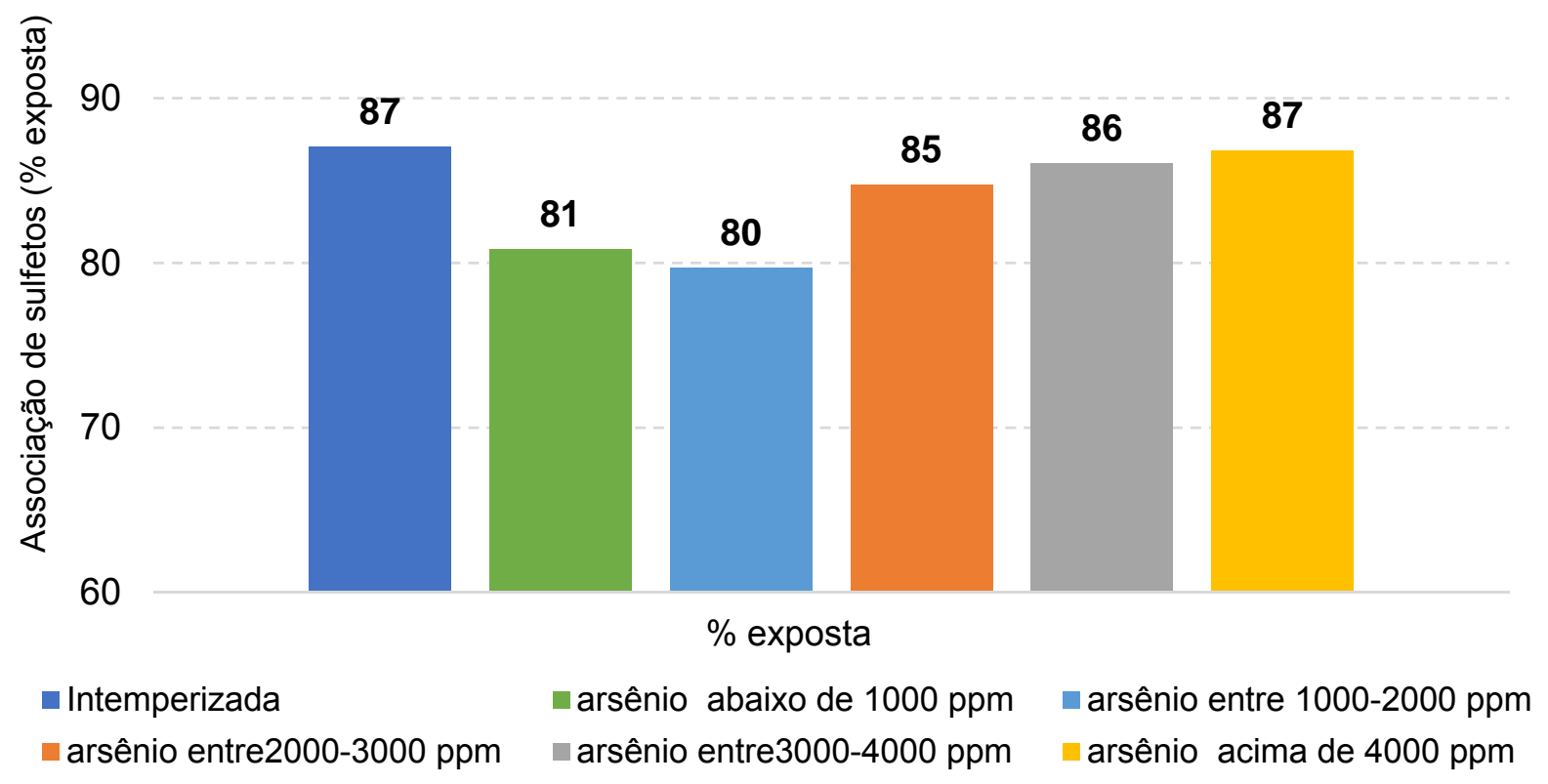

A Figura 5.7 ilustra as principais associações dos sulfetos determinadas pelo perímetro de contato destes com as demais fases presentes na amostra; quartzo, seguido por mica, e carbonatos são os principais minerais de ganga associados aos sulfetos. 
Figura 5.7 - Associação mineral por perímetro de contato - Sulfetos totais; fração $0,50+0,020 \mathrm{~mm}$

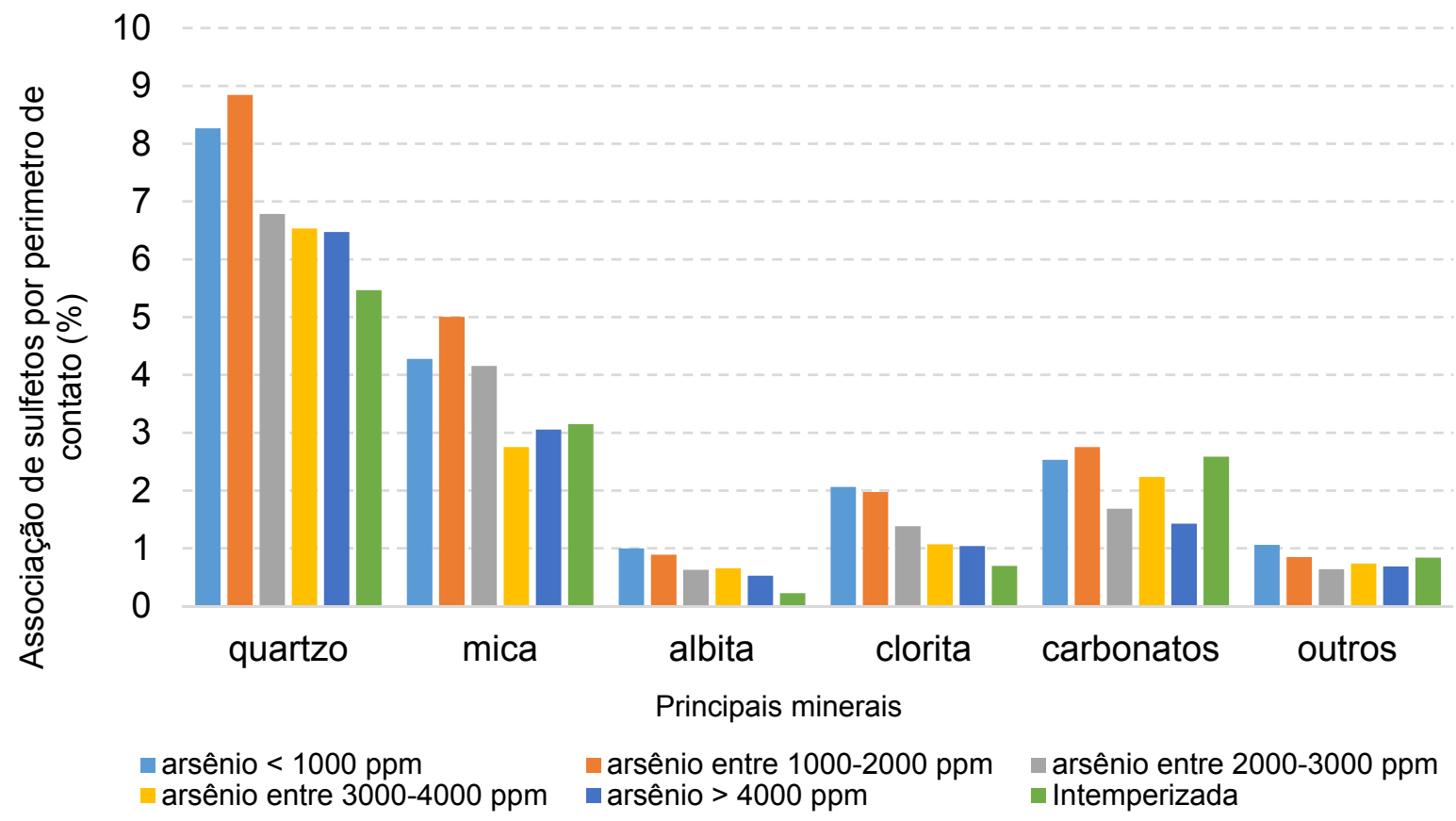

Outros: ilmenita, rutilo, zircão, apatita, monazita, AlFe-PbAsO, FeAsO

Carbonatos: siderita + anquerita

\subsection{ESTIMATIVA DA DISTRIBUIÇÃO DE OURO}

O conceito de liberação aplicada a minérios auríferos se difere de outros minérios, como por exemplo minério de ferro, porque uma parcela considerável dos processos empregados baseia-se na dissolução química deste elemento (lixiviação), bastando que o grão de ouro esteja susceptível à uma solução através de um meio (fratura, micro porosidade) não havendo a necessidade de liberação física deste em relação aos minerais de ganga (ouro acessível).

Conforme definido no item 2.4.4, um grão de ouro acessível significa que basta ele ter 1 pixel de seu perímetro exposto (2D).

A Figura 5.8 indica que a uma tendência no aumento da parcela de ouro acessível (2D) de forma gradativa com o aumento teor de arsênio. A inclusão e não encapsulamento dos grãos de ouro nos minerais ocorre de forma decrescente em relação ao grau de exposição de ouro 
Figura 5.8 - Ouro acessível, não encapsulado e incluso determinados a partir dos perímetros de contato dos grãos de ouro (produto afundado; fração -0,50+0,020 mm)

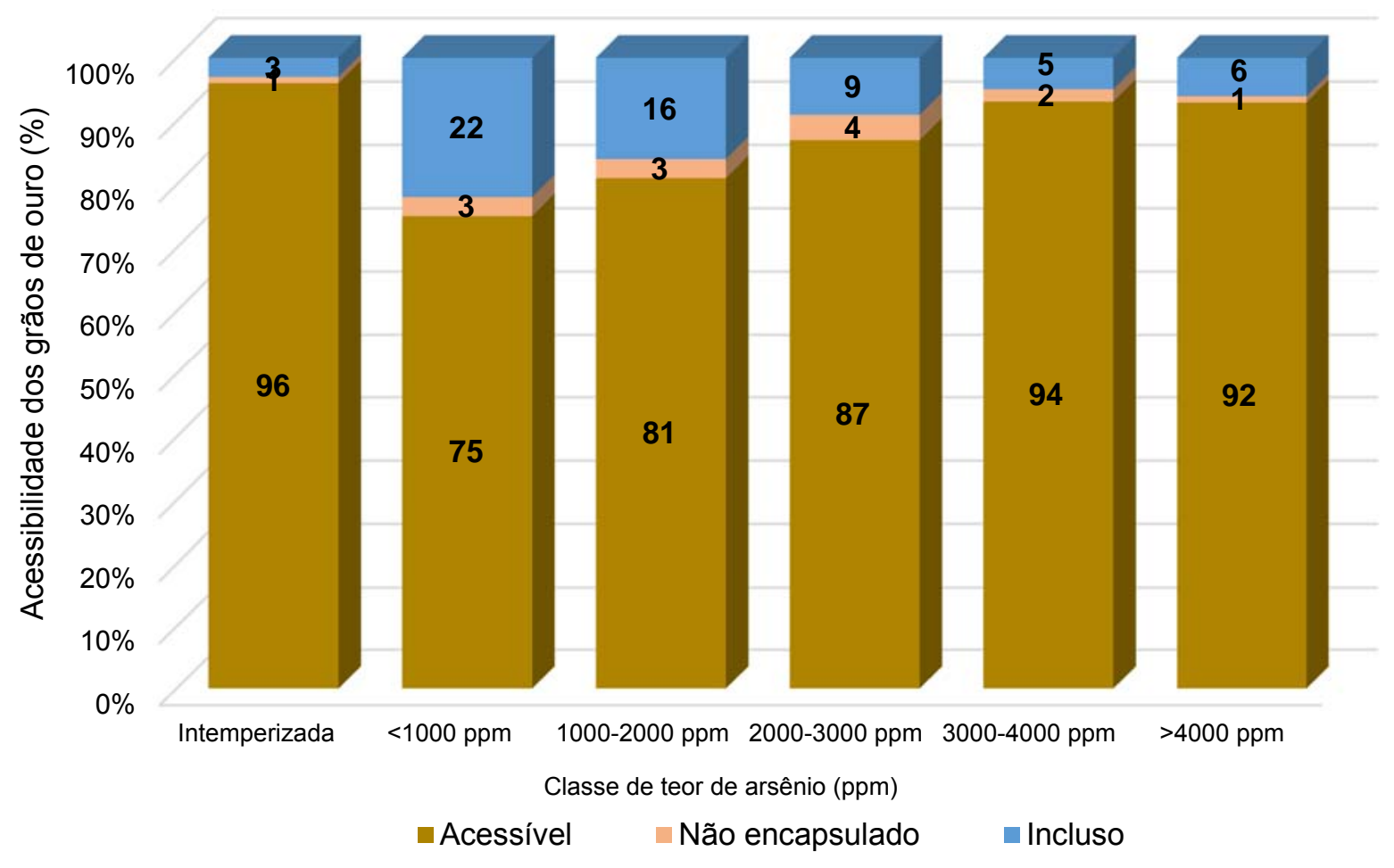




\section{CONCLUSÕES}

Nas amostras de minério de ouro da Mina Morro do Ouro, correspondentes aos materiais de frente de lavra e testemunho de sondagem, verifica-se uma forte relação entre os teores de ouro, enxofre e arsênio.

A composição química das amostras, determinadas por espectrometria de fluorescência de raios $X$ mostrou um elevado conteúdo de $\mathrm{SiO}_{2}$ relacionados principalmente a presença de boudins de quartzo. A mineralização de ouro ocorre principalmente associada a esses boudins, em concentrações sulfetadas na forma de clusters sulfetados. Conteúdo de $\mathrm{Al}_{2} \mathrm{O}_{3}, \mathrm{MgO}, \mathrm{Na}_{2} \mathrm{O}$ e $\mathrm{K}_{2} \mathrm{O}$ estão presentes devido a recorrência de mica, caulinita e albita nas amostras.

Para cominuição abaixo de $0,50 \mathrm{~mm}$ a distribuição em massas das amostras no peneiramento em $0,020 \mathrm{~mm}$ mostrou uma média de 20 a 30\% na fração passante. Algumas amostras apresentaram fora da média; com valores acima de $40 \%$ em massa abaixo da fração $0,020 \mathrm{~mm}$, o que sugere amostras mais intemperizadas.

O ouro ocorre majoritariamente acima da fração 0,020 mm com média de $93 \%$ contido. As amostras ACT-085, 086, 048 apresentaram, na fração abaixo de 0,020 mm, conteúdo acima de $20 \%$, o que pode ser explicado devido a maior proporção de sulfetos nessa fração.

Semelhante ao ouro, o enxofre está contido abaixo de $0,020 \mathrm{~mm}$ na ordem de $10 \%$, em média. Nas amostras ACT-085, 086 e 087 a parcela é superior a 30\%.

Nas separações minerais em líquido denso tem-se em média 88\% de massa na fração $-0,50+0,020 \mathrm{~mm}$ junto ao no produto flutuado (exceto nas amostras ACT-083 com $72 \%$ de massa no produto flutuado, ACT-084 com 73\%, ACT-057 com 66\% e ACT087 com $54 \%$ de massa no flutuado). No geral, o produto afundado representa $12 \%$ em massa e, em média, é responsável por $95 \%$ de todo enxofre na amostra, $85 \%$ do arsênio e $90 \%$ do ouro contido.

A difratometria de raios $X$ apresentou a recorrência de quartzo e muscovita em todas as amostras. Constituintes minerais em menores proporções tais como feldspato (albita), goethita, clorita (clinocloro), caulinita, sulfetos (arsenopirita, pirita, galena) e 
duas variedades de carbonatos: anquerita e siderita, ocorrem em proporções variadas nas amostras.

As composições mineralógicas nos materiais obtidas por MEV-MLA para a fração 0,50+0,020 mm confirmam a presença considerável de quartzo e mica, que somadas respresentam cerca de $80 \%$ da massa total das amostras

Em relação ao conteúdo de sulfetos nas amostras $(-0,50+0,020 \mathrm{~mm})$ se observa o predominio de pirita e arsenopirita em diferentes proporções nas amostras com algumas evidenciando comportamento distintos:

- pirrotita: em algumas amostras as proporções de pirrotita dentre os sulfetos pode atingir valores de 20 a 53\% relativos (ACT-042, 035, 080, 009, 063, 062, 014, 054, 086 e 048).

- outros sulfetos (calcopirita, esfalerita e galena): a amostra ACT-079 tem uma proporção de $44 \%$ de outros sulfetos, sendo que as amostras ACT- 001, 014, 022, ACT-078 e 087 também mostram conteúdos expressivos (15 a 25\% da distribuição total de sulfetos).

As medianas das distribuições de tamanho dos grãos de ouro apresentam um valor médio de $19 \mu \mathrm{m}$ com uma grande dispersão, não sendo possível relacionar com outras variáveis avaliadas (máximo de $70 \mu \mathrm{m}$ e mínimo de $2 \mu \mathrm{m}$ ). Pouco menos de $10 \%$ das amostras apresentam valores de $D_{50}$ dos grãos de ouro acima de $50 \mu \mathrm{m}$ (ACT-005, 027, 074, 082 e 085). Para os clusters de sulfetos a mediana da distribuição dos tamanhos ficou por volta de 80 a $100 \mu \mathrm{m}$, próximo ao diâmetro da alimentação da flotação ( $P_{80}$ de $\left.106 \mu \mathrm{m}\right)$.

Em termos de associações minerais verifica-se que de maneira geral, o ouro está em grande parte associado aos sulfetos com pouca contribuição nos silicatos, carbonatos e outros sulfetos (calcopirita, esfalerita e galena); com o aumento de teor de arsênio, cresce a parcela de ouro associado à arsenopirita.

As associações de perímetro dos grãos de ouro ocorrem principalmente na forma acessível (pelo menos 1 pixel no perímetro do grão - 75 a $96 \%$ do ouro no produto afundado acima de $0,020 \mathrm{~mm}$ ) e, secundariamente, associado a pirita, arsenopirita e, mais raramente, com siderita (ACT-008), clorita (ACT-070) e outros (ACT-016). Como 
exceção, tem-se 9 amostras com mais de $70 \%$ do ouro em grãos integralmente inclusos na pirita e na arsenopirita (ACT-084, 055, 080, 002, 062, 081, 065, 025 e 036). Em relação a sua composição, verifica-se uma diversidade composicional, com média de $77 \%$ de ouro e $23 \%$ de prata, com desvio padrão de $13 \%$ (valores mínimos de $30 \%$ e máximo $100 \%$ de ouro).

Para material cominuído abaixo de $0,50 \mathrm{~mm}$ tem-se expressiva parcela de ouro com exposição de perímetro de grãos (2D, média de 73\%); o ouro incluso está essencialmente associado a pirita e arsenopirita e representa em média $21 \%$ do total dos grãos de ouro, sendo que em 14 das 88 amostras este valor pode superar $40 \%$ do total de ouro contido.

A classificação das amostras quanto aos seus conteúdos finos $(-0,020 \mathrm{~mm})$ e de arsênio gerou 6 classes distintas de minério. O conteúdo médio total de sulfetos é praticamente o mesmo para o material intemperizado e as classes com até 3000 ppm de arsênio (cerca de 2,5\% em massa); a partir daí os conteúdos de sulfetos (pirita, arsenopirita e pirrotita) aumentam expressivamente mostrando uma tendência de acréscimo de arsenopirita e pirrotita com ligeiro decréscimo na pirita. Ocorre também uma variação brusca no conteúdo de arsenopirita e da relação arsenopirita/pirita para a classe de arsênio acima de 4000 ppm.

A distribuição acumulada do tamanho dos grãos de ouro mostra uma tendência em relação ao tamanho e conteúdo de arsênio. As classes com conteúdo de arsênio acima de 3000 ppm apresentam maiores diâmetro d50 dos grãos de ouro; no entanto, o maior diâmetro médio dos grãos de ouro é da classe de minério intemperizado. Em relação aos sulfetos, a arsenopirita mostrou-se d50 superior aos demais sulfetos em todas as 6 classes de minério.

O perímetro de contato do ouro (associação mineral) por classe de arsênio apresenta um aumento no grau de exposição (perímetro exposto) e associação com arsenopirita nas classes com maior teor de arsênio. Há uma diminuição progressiva na associação com a pirita e a clorita.

A estimativa da distribuição de associações de perímetro dos grãos de ouro mostra uma elevação do perímetro exposto (mínimo de $75 \%$ e máximo de $92 \%$ ) em direção 
aos maiores teores de arsênio, com diminuição tanto dos grãos não encapsulados como nos inclusos.

\subsection{SUGESTÕES DE TRABALHOS COMPLEMENTARES}

O presente estudo permitiu estabelecer as principais associações mineralógicas e características dos sulfetos e dos grãos de ouro para o depósito Morro do Ouro. No entanto, os resultados dos trabalhos realizados suscitaram algumas questões e sugestões para estudos complementares:

1. Análise crítica dos resultados gerados em função da distribuição espacial das amostras estudadas e outras eventuais informações georeferenciadas disponíveis;

2. Foi detectada uma variação expressiva da composição dos grãos de ouro $(\mathrm{Au} / \mathrm{Ag})$ que não foi objeto de detalhamento e pode ter implicações relevantes na etapa de cianetação (recuperação tende a diminuir com o incremento de prata nos grãos de ouro/electrum);

3. O minério, a exceção do material intemperizado (praticamente esgotado), mostra características distintas em função dos teores de arsênio: associações e granulação de ouro e sulfetos, além de acessibilidade do ouro. Para melhor compreensão destas variáveis no processo sugere-se a realização de amostragem volumétrica de amostras com distintos teores de arsênio, seguida de processamento das mesmas simulando as condições de operação industrial (ou mesmo processamento em usina para fins de benchmark) seguido de estudos detalhados de caracterização da alimentação e rejeitos de flotação e de cianetação;

4. Foram verificadas amostras com comportamentos distintos, com por exemplo, ouro de granulação mais fina essencialmente incluso em sulfetos. Como as amostras estudadas mostram baixa representatividade espacial deve se verificar se estas mesmas características são verificadas em escala de lavra e se podem ter implicações no processamento do minério. Em caso afirmativo, sugere-se a realização de estudos geometalúrgicos considerando emprego das 
mesmas ferramentas adotadas no presente estudo paralelamente a ensaios de flotação e/ou cianetação em escala de bancada. 


\section{REFERÊNCIAS BIBLIOGRÁFICAS}

ADAMS, M. D.; BURGER, A. M. Characterization and blinding of carbonaceous pregrobbers in gold ores. Minerals Engineering, v. 11, n. 10, p. 919-927, 1998.

ALMEIDA, F. F. M. Origem e evolução da plataforma brasileira. Rio de Janeiro, Bol. DNPM, v. 243, p. 36. 1967.

ALMEIDA, B.S. Gênese de depósitos dos filitos carbonosos do depósito Morro do Ouro. Dissertação de mestrado - UnB, p. 90, 2009.

AMTEL. Gold losses in the tails fines of the Paracatu sulphides leach circuit. Kinross Brasil Mineração. Relatório interno. 2010.

ARAÚJO, M. I. S. O ouro como valor de refúgio. 2013. 63p. Tese (Mestrado) Universidade do Minho. Portugal. 2013.

AYLING, B. QEMSCAN® - Quantitative evaluation of minerals by scanning electron microscopy: capability and application to fracture characterization in geothermal systems. In: AGU Fall Meeting Abstracts, 2011.

BADRI, R.; ZAMANKHAN, P. Sulphidic refractory gold ore pre treatment by selective and bulk flotation methods. Advanced powder technology , n. 24, p. 512-519, 2013.

BARBOSA, O. Geologia e recursos minerais do projeto Brasília. PROSPECDNPM, 225 p. (Relatório Interno). 1969.

BAUR, D. G.; MCDERMOTT, T. K. Is gold a safe haven? International evidence. Journal of Banking and Finance, v. 34, n. 8, p. 1886-1898, 2010.

BIERLEIN, F. P.; GROVES, D. I.; GOLDFARB, R. J.; DUBE, B. Lithospheric controls on the formation of provinces hosting giant orogenic gold deposits. Mineralium . Deposita. v. 40, p. 874-886. 2006.

BISH D. L.; POST, J. E. (Ed.). Modern powder diffraction. Washington: Mineralogy Society of America, Reviews in Mineralogy, v. 20 p. 73-99, 1989.

BLUE COAST METTALURGY. Mineralogical Review. Relatório interno. 2010.

CARMO, S. S. Preparação de amostras e rotinas de análise microscopia de imagem automatizada eletrônica por de varredura. 2015. 83 p. Dissertação (Mestrado) - Escola Politécnica, Universidade de São Paulo, São Paulo. 2015.

CARVALHO, M. C. A. M. Paracatu: Morro do Ouro. São Paulo, Ed. Abril S. A., 91p. 1992. 
CHAPADEIRO, E. Estudos hidrogeológicos na mina Morro do Ouro. XIV CBAS, 2006

CHAVES, A.P., CHAVES FILHO, R. C. Separação densitária. Teoria e prática do tratamento de minérios. São Paulo: Oficina de texto. 2013.

CHIEREGATI, A.C. Reconciliação pró-ativa em empreendimentos mineiros. 201 p. Tese de Doutorado - Escola Politécnica, Universidade de São Paulo, São Paulo, 2007.

CHRYSSOULIS, S. L.; CABRI, L. J. Significance of Gold Mineralogical Balances in Mineral Processing. Transactions of the Institution of Mining and Metallurgy, Section C, v. 99, p. C1-C10, 1990.

CIMINELLI, V.S.T.; GOMES, A.D. Princípios da cianetação. In: TRINDADE, R.B.E.; BARBOSA FILHO, O. Extração de Ouro - Princípios, Tecnologia e Meio Ambiente. Rio de Janeiro: CETEM/MCT, p. 59-94. 2002.

CLINE, J. S.; HOFSTRA, H. A.; MUNTEAN, L. J.; TOSDAL, R. M. Carlin Type Gold Deposits in Nevada: Critical Geologic Characteristics and viable Models. Society of Economic Geologists, Inc. Economic Geology 100th Anniversary. p. 451-484, 2005.

DAITX, E.C.; ZANARDO, A. Estudo petrográfico e minerográfico de rochas da Mina Morro do Ouro, Paracatu, MG. vol 2. Programa Parceria RPM/Fundunesp. Relatorio interno. 2000.

DARDENNE, M. The Brasilia Fold Belt. IN: 31st International Geological Congress, Rio de Janeiro, 2000. Tectonic Evolution of South America, pp 231 -263. 2000.

DNPM. Anuário Mineral Brasileiro. v. 35, p. 871, 2010.

DOBBE, R.; GOTTLIEB, P.; GU, Y.; BUTCHER A. R.; FANDRICH, R.; LEMMENS $\mathrm{H}$. Scanning electron beam-based automated mineralogy-outline of technology and selected applications in the natural resources industry. In: 11th European workshop on modern development and applications in microbeam analysis. Proceedings. Poland: p. 169-189. 2009.

ESPER, E.; RUGOLO, R.; MOLLER, J. C.; AKITI, Y.; PAINS, A. Morro do Ouro Geological model with a metallurgical view, The second AUSIMM International Geometallurgy Conference, Brisbane, pp 67-74. 2013.

FANDRICH, S.; SCHNEIDER C. L.; GAY, S. L. Two stereological correction methods: Allocation method and kernel transformation method. Minerals Engineering. vol. 11, no. 8, p. 707-715. 1998. 
FANDRICH, R.; GU, Y.; BURROWS, D.; MOELLER, K. Modern SEM-based mineral liberation analysis. International journal of Mineral Processing. v. 84, p. 310-320. 2007.

FORBES, E.; DAVEY, K. J.; SMITH, L. Decoupling rehology and slime coatings effect on the natural flotability of chalcopyrite in a clay-rich flotation pulp. Minerals Engineering. vol. 56, p. 136-144, 2014.

FORTEY, N. J. Image analysis in mineralogy and petrology. Mineralogical Magazine. vol. 59, p. 177-178, 1995.

FREITAS SILVA, F. H. Enquadramento litoestratigrafico e estrutural do depósito de ouro do Morro do Ouro, Paracatu, MG. Tese (Mestrado) - IG/UnB, Brasília, 151p. 1991.

FREITAS SILVA, F. H. Controles litoestruturais do depósito de ouro do Morro do Ouro, $6^{\circ}$ Simpósio de geologia de Minas Gerais, 1991.

FREITAS SILVA, F. H. Metalogênese do depósito do Morro do Ouro, Paracatu. Congresso Brasileiro de Geologia. Salvador, SBG. v. 7, p. 207-209. 1996.

FREITAS SILVA, F. H. Metalogênese do depósito do Morro do Ouro, Paracatu, MG. Tese (Doutorado) - IG/UnB, Brasília, 339p. 1996.

FREITAS, L. R.; COSTA, R. S. Recuperação do ouro dissolvido. In: TRINDADE, R.B.E.; BARBOSA FILHO, O. Extração de Ouro - Princípios, Tecnologia e Meio Ambiente. Rio de Janeiro: CETEM/MCT, p. 95-133. 2002.

FRIMMEL, H. E. Earth's continental crustal gold endowment. Earth and Planetary Science Letters, v. 267, n. 1-2, p. 45-55, 2008.

FUCK, R. A Faixa Brasilia e a Compartimentação Tectônica na Província Tocantins. IN: IV Simpósio da Geologia do Centro Oeste. Anais, SBG, p. 184-187, Brasília. 1994.

GALERY, R. Fragmentação de minérios: primeira parte. Belo Horizonte: Ed. da UFMG, 2011.

GALLEY, A. G.; HANNINGTON, M. D.; JONASSON, I. R. Volcanogenic Massive Sulfide Deposits. In Goodfellow, W D. ed., Mineral Deposits of Canada: A Synthesis of Major Deposit-Types, District Metallogeny the Evolution of Geological Provinces and Exploration Methods, n. 5, p. 141-161, 2007.

GAUDIN, A.M. Principles of mineral dressing. New Delhi: Tata McGraw Hill,. 554 p. 1939. 
GOMES, A. M. D. Lixiviação e adsorção em Fazenda Brasileiro - CVRD: uma questão de produtividade. 1999. 200 p. Tese (Doutorado) - Escola Politécnica, Universidade de São Paulo, São Paulo. 1999.

GOTTLIEB, P. et. al. Using quantitative electron microscopy for process mineralogy applications. Jom, v. 52, n. 4, p. 24-25, 2000.

GÖTZE, J. Potential of cathodoluminescence (cl) microscopy and spectroscopy for the analysis of minerals and materials. Analytical and Bioanalytical Chemistry, v. 374, n. 4, p. 703-708, 2002.

GRANT, G., HALL J.S., REID, A.F., ZUIDERWYK, M.A. Characterisation of particulate and composite mineral grains by on-line computer processing of SEM images. In: Proceedings 15th APCOM Symposium, Brisbane, Australia, pp. 159-169, 1977.

GROVES, D.J., GOLDFARB, R.J., GEBRE-MARIAM, M., HAGEMANN, S.G., AND ROBERT, F. Orogenic gold deposits: A proposed classification in the context of their crustal distribution and relationships to other gold deposit types: Ore Geology Reviews, vol. 13, 7-27 p. 1998.

GROVES, D. I. et al. 100th Anniversary special paper: Secular changes in global tectonic processes and their influence on the temporal distribution of gold-bearing mineral deposits. Economic Geology, v. 100, n. 2, p. 203-224, 2005.

GU, Y. Automated scanning electron microscope based mineral liberation analysis. An introduction to JKMRC/FEl Mineral Liberation Analyser. Journal of Minerals and Materials Characterization and Engineering, v. 2, n. 1, p. 33-41, 2003.

GY, P. Sampling for analytical purposes. Translated by A. G. Royle. John Wiley \& Sons, West Sussex, England, 1998.

HABERLAH, D. et al. SEM-EDS based protocol for subsurface drilling mineral identification and petrological classification. $10^{\text {th }}$ International Congress for applied mineralogy. v. 34, p. 265-273, 2011.

HARRIS, D. C. The Mineralogy of gold and its relevance to gold recoveries. Mineralium Deposita, v. 25, n. 1, p. 3-7, 1990.

HARTNADY, C. J. H. South Africa's gold production and reserves. South African Journal of Science, v. 105, n. 9-10, p. 328-329, 2009.

HEDENQUIST, J. W.; LZAWA, E.; ARRIBAS, A; WHITE, N. C. Epithermal Gold Deposits: Styles, characteristics, and exploration. Resource Geology Special Publication. Tokyo: Society of Resource Geology. n. 1, 16p, 1996.

HENLEY, R W. Epithermal gold deposits in volcanic terranes. In: Foster, R. P. (Ed.) Metaliogeny and Exploration. London: Blackie. p. 133-164, 1991. 
HENLEY, K. J. Ore-Dressing Mineralogy - a review of techniques, applications and recent developments, Geological Society of South Africa, vol 7(7), p. 175-200, 1983.

HENLEY, K. J. A combined mineralogical/metallurgial approach to determining the nature and locating of gold in ores and mill products. Minerals Engineering, v. 2, n. 4, p. 459-470, 1989.

HUYNH L.; FEILER A.; MICHELMORE A.; RALSTON J.; J. P. Control of slime coating by the use of anionic phosphates: A Fundamental study. Minerals Engeneering, $v$. 13, n. 10, p. 1059-1069, 2000.

IBRAM. Ouro. Anuário Brasileiro Mineral, v. 7, p. 55-57, 2012.

JENKINS, R. Instrumentation. In: BISH, D.L., POST, J.E. (Ed). Modern powder diffraction. Washington: Mineralogy society of America. Reviews in mineralogy. v. 20. p. 19-43.1989.

JOST, H.; OLIVEIRA, A. M. Stratigraphy of the greenstone belts, Crixás region, Goiás, central Brazil. Journal of South American Earth Sciences, v. 4, n. 3, p. 201-214, 1991.

JONES, M. P. Applied mineralogy - a quantitative approach. United States: Graham \& Trotman, 1987.

JUNIOR, G.G.O. Desenvolvimento de uma rota de processo de dessulfurização de rejeitos de um minério aurífero sulfetado. Dissertação de mestrado - UFMG. p. 71 2011.

KLEMM, D.; KLEMM, R.; MURR, A. Gold of the Pharaohs -6000 years of gold mining in Egypt and Nubia. Journal of African Earth Sciences, v. 33, n. 3-4, p. 643-659, 2001.

KOJONEN, K.; JOHANSON, B. Mineralogy and Petrology Determination of refractory gold distribution by microanalysis, diagnostic leaching and image analysis. Mineralogy and Petrology, v. 67, p. 1-19, 1999.

LATTI, D. An assessment of Au Distribution in a Suite of Samples from RPM. Rio Tinto Research and Technical Development. Melbourne, Australia, (Relatório Interno). 1999a.

LATTI, D. Particles in Four Ore Samples from the Morro do Ouro Mine, Brazil. Rio Tinto Technical Services Development. Bristol, Inglaterra. (Relatório Interno), 1999. 1999b.

LOBATO L.M., RIBEIRO RODRIGUES L.C., ZUCHETTI, M., NOCE, C.M., BALTAZAR O.F., DA SILVA L.C., PINTO, C.P.; Brazil's premier gold province: part I: the tectonic, 
magmatic and structural setting of gold deposits in the Archean Rio das Velhas greenstone belt, Quadrilátero Ferrífero. Mineralium Deposita v. 36: p.249-277 2001.

LOTTER, N. O. Modern Process Mineralogy: An integrated multi-disciplined approach to flowsheeting. Minerals Engineering, v. 24, n. 12, p. 1229-1237, 2011.

MADALLOSO A.; VALLE, C.R.O. Considerações sobre a estratigrafia e sedimentologia do Grupo Bambuí na região de Paracatu-Morro Agudo (MG). IN: Congresso Brasileiro de Geologia 30, pp. 622-631, 1978

MADALLOSO A. Considerações sobre a paleogeografia do Grupo Bambuí na região de Paracatu-Morro Agudo (MG). In: SBG, Congresso Brasileiro de Geologia 31, Recife, Anais, vol. 2, pp. 622-634, 1980.

MARINI, O. J. A evolução geotectónica da Faixa Brasilia e de seu embasamento. IN: Simpósio Sobre o Cráton de São Francisco e suas Faixas Marginais, CPM/SBG, p.100-115, 1981.

MARTINI, S. L. An overview of main auriferous regions of Brazil. Revista Brasileira de Geociências, Vol. 28(3) p.307-314 1998

MARSDEN, J., HOUSE, I. The chemistry of gold extraction. Colorado: Society for mining, metallurgy and exploration, Inc., 1992.

MARQUES, F. B. Geologia, mineralização e lavra do Morro do Ouro - Paracatu (MG). $3^{\circ}$ Congresso Brasileiro de Geologia, Salvador. 1993

MASCARENHAS, J. F.; LEDRU, P.; SAMUEL, L. S.; CONCEIÇÃO FILHO, V. M.; MELO, L. F. A.; LORENZO, C. L. \& MILÉSI, J. P. Geologia e recursos minerais do Grupo Jacobina e da parte sul do Greenstone Belt de Mundo Novo, v. 13, Salvador, CBPM, p. 58, 1998.

MONTE, M. B. M.; SAMPAIO, J. A.; GONTIJO, P. F.; TONDO, Luis Albano . Ouro Rio Paracatu Mineração. In: João Alves Sampaio; Adão Benvindo da Luz; Fernando Antônio Freitas Lins. (Org.). Usinas de Beneficiamento de Minérios do Brasil.: , 2001, v. 1 , p. $362-372$

MENESES , P. R.; FREITAS SILVA, F. H; PARADELA, W. R.; JUNIOR, L. G. F. O comportamento espectral e radiométrico portadores de mineralizações auriferasna Faixa Brasilia. Anais do VII SBSR, p 266-274, 1993

MILTZAREK, G. L. Estudo sobre reutilização dos cianetos empregados no tratamento de minério aurífero por meio de soluções sintéticas e efluentes da cianetação. Vasa, p. 86, 2000.

MOLLER, J C, BATELOCHI, M A, AKITI, Y, SHARRAT, BORGES, A L. Geologia e caracterização dos recursos minerais de Morro do Ouro, (Geology and mineral 
resource characterisation of Morro do Ouro Mine) Paracatu, Minas Gerais, in Bacia do São Francisco, Belo Horizonte, p. 199-234. 2001.

MOLLER, J. C. The Geology and Characterization of Mineral Resources of Morro do Ouro, Paracatu, MG; Relatório interno, p. 57. 2001.

MONTEIRO, L. V. S.; XAVIER. R. P.; HITZMAN, M. W.; JULIANI, C. FiLHO, C. R. S; CRAVALHO, E. R. Mineral chemistry of ore and hydrothermal alteration at the Sossego iron oxide-copper-gold deposit, Carajás Mineral Province, Brazil. Ore Geology Reviews, v. 34, p. 317-336, 2008.

MYASHITA, A. Mapeamento estrutural da Mina Morro do Ouro, Paracatu, MG. Relatório interno, p. 47. 2005.

O'CONNOR, C. T.; DUNNE, R. C. The flotation of gold bearing ores - a review. Minerals Engineering, v. 7, n. 7, p. 839-849, 1994.

OLIVER , N. H. S., et al,. Local and regional mass transfer during thrusting, veining, and boudinage in the genesis of giant shale-hosted Paracatu Gold Deposits, Minas Gerais, Brazil. Economic Geology, v. 110, p. 1803-1834, 2015.

PERES, A. E. C. Caracterização mineralógica e tecnológica. In: VALADÃO, G. E. S.; DE ARAÚJO, A. C. (Eds.). Introdução ao tratamento de minérios. 1. ed. Belo Horizonte: UFMG. 2007.

PERONI, R. L. Lavra a Céu Aberto - Teoria e prática. Porto Alegre: Universidade do Rio Grande do Sul, 172 p. 2008.

PETRUK, W. Short Course on Image Analysis Applied to Mineral and Earth Sciences. Ottawa: Mineral Association of Canada, 156 p. 1989.

PETRUK, W. General principles of applied mineralogy. 2000.

REES, K. L., VAN DEVENTER, J. S. J. Preg-robbing phenomena in the cyanidation of sulphide gold ores. Hydrometallurgy vol. 58, p. 61-80. 2000.

ROBB, L. J.; MEYER, F. M. The Witwatersrand Basin, South Africa: Geological framework and mineralization processes. Ore Geology Reviews, v. 10, n. 2, p. 6794, 1995.

ROBERT, F.; POULSEN, K. H.; DUBE, B. Gold Deposits and Their Geological Classification. Proceedings of Exploration 97: Fourth Decennial International Conference on Mineral Exploration, p. 209-220, 1997.

RUSS, J.C. Practical stereology. New York: Plenum press p. 185. 1986. 
SAMPAIO, C.H.; TAVARES, L.M.M. Beneficiamento gravimétrico: Uma introdução aos processos de concentração mineral e reciclagem de materiais por densidade. Porto Alegre: UFRGS Editora, 605 p. 2005.

SANT'AGOSTINO, L.M., KAHN, H. Metodologia para caracterização tecnológica de matérias primas minerais. Tese (Boletim técnico) - Escola politécnica, Universidade de São Paulo, São Paulo. 29 p, 1997.

SCHOBBENHAUS, C; DARDENNE, M.A. Metalogênese do Brasil. Brasília: Editora Universidade de Brasília, 392 p. 2001.

SCHORSCHER, H.D.; Komatiitos na estrutura Greenstone Belt Série Rio das Velhas, Quadrilátero Ferrífero, Minas Gerais, Brasil. In Congresso. Brasileiro de Geologia, 30. Recife, Resumo das Comunicações, p. 292-293, 1978.

SILLITOE, R. H. Erosion and collapse of volcanoes: Causes of telescoping in intrusioncentered ore deposits. Geology, v. 22, p. 945-948, 1994.

SILVA, A. H. M. Modelagem geológica e estocástica da porção NE da Mina de Morro do Ouro, Paracatu. Dissertação de mestrado - Unicamp, 2001.

SILVA, A. L. Moagem Semiautógena piloto do minério de ouro da Rio Paracatu Mineração. Dissertação de mestrado - Poli-USP, p. 125, 2012

SIMON, G.; KESLER, S. E.; CHRYSSOULIS, S. Geochemistry and textures of goldbearing arsenian pyrite, Twin Creeks, Nevada: Implications for deposition of gold in Carlin-type deposits. Economic Geology, v. 94, n. 3, p. 405-421, 1999.

SUN, W. et al. Porphyry deposits and oxidized magmas. Ore Geology Reviews, v. 65, p. 97-131, 2015.

SWALF, P.S. Modelo exploratório para depósitos auríferos do tipo Morro do Ouro com base em dados e técnicas de sensoriamento remoto. Dissertação de mestrado Unicamp, 2000

SWALF, P.S., CROSTA, A. P., FILHO, C. R. S. Remote sensing signature of the Morro do Ouro gold deposit, Minas Gerais, Brazil, using reflectance spectrometry: application to mineral exploration using spaceborne multispectral sensors. RBG, vol. 33(2Suplemento), p. 221-227.

TASSINARI, M. M. L., Caracterização tecnológica de minérios auríferos: um estudo de caso, o minério primário da jazida de Salamonge, AP. 1996. Dissertação (Mestrado) - Escola Politécnica, Universidade de São Paulo, São Paulo, 1996.

THORMAN, C. H. New ideias regarding the origin and tectonic settinh of mineral deposits (Morro agudo $\mathrm{Zn}-\mathrm{Pb}$ and Morro do Ouro) in Paracatu-Vazante fold belt, MInas Gerais. Congresso Brasileiro de Geologia, Camboriú, vol 3, p 39 - 42, 1996. 
USGS. Mineral commodity summaries. n. 703, p. 66-67, 2015.

WILLIAMS, P.; BARTON, M. Iron oxide copper-gold deposits: Geology, space-time distribution, and possible modes of origin. Economic Geology, v. Anniversar, p. 371405, 2005.

ZHOU, J.; JAGO, B.; MARTIN, C. Establishing the process mineralogy of gold ores. SGS Minerals - Technical Bulletin, 2004.

ZINI, A. Depósito de ouro do Morro do Ouro, Paracatu, Minas Gerais. In: Principais depósitos minerais do Brasil. Brasília, DNPM. v.3. p. 479-489. 1988. 


\section{APÊNCIDE 1 - Proveniência e composição química das amostras}

\begin{tabular}{|c|c|c|c|c|c|c|c|c|c|c|c|c|c|}
\hline \multirow{2}{*}{ Proveniência } & \multirow{2}{*}{ Amostra } & \multicolumn{10}{|c|}{ Teores (\%) } & \multicolumn{2}{|c|}{ Teores (ppm) } \\
\hline & & $\mathrm{SiO}_{2}$ & $\mathrm{I}_{2} \mathrm{O}_{3}$ & $\mathrm{Fe}_{2} \mathrm{O}_{3}$ & $\mathrm{Na}_{2} \mathrm{O}$ & $\mathrm{K}_{2} \mathrm{O}$ & $\mathrm{CaO}$ & MgO & $\mathrm{TiO}_{2}$ & PF & S & As & $\mathrm{Au}$ \\
\hline Son & & 60,4 & 13,8 & 8,52 & 0,19 & 5,48 & 06 & 93 & 0,75 & 6,18 & 1,85 & 367 & 966 \\
\hline Sond & ACT-002 &, 3 & 11 & 5,72 & 42 & 4,17 & 0,52 & 0,88 & 61 & 79 & 22 & 30 & 1,105 \\
\hline So & 3 & 6 & 12,7 & 6 & 2 & 4,64 & 0,81 & 3 & 8 & 33 & 24 & 35 & 331 \\
\hline So & 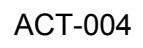 & 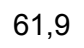 & 1 & 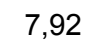 & 4 & 5,20 & 19 & 7 & 76 & 49 & 4 & 20 & 17 \\
\hline Sor & & 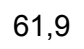 & 13,7 & 7,26 & 0,67 & 5,32 & 0,60 & 1,03 & 31 & 0 & 64 & 60 & 1,097 \\
\hline rente de lavr & & 72,1 & 11,7 & 4,82 & 0,15 & 4,59 & 0,21 & 0,75 &, 61 & 3,19 & 0,87 & 91 & 1,771 \\
\hline em & ACT-007 & 6 & רז & ד, & 4 & 9 & 1,16 & 1 & 3 & 4,15 & & 229 & 081 \\
\hline avra & ACT &, 0 & 13 & 8,84 & 1 & 6 & 0,44 & & & 2 & & & \\
\hline de lavra & $\mathrm{ACT}$ & 1,0 & 8,74 & 5,68 & 0,47 & 3,14 & 1,08 & 0,93 &, 46 & 4,47 & & 800 & 0,839 \\
\hline Frente de lavra & ACT-010 & 65,0 & 11,6 & 5,99 & 0,68 & 3,91 & 0,39 & $<0,01$ & 0,58 & 5,65 & 2,74 & 18515 & 0,486 \\
\hline Frente de lavra & ACT-011 & 74,8 & 10,6 & 3,63 & 0,32 & 4,22 & 0,13 & 0,72 & 0,60 & 2,84 & 0,73 & 4684 & 0,992 \\
\hline Frente $\mathrm{d}$ & ACT-012 & 66,6 & 11,4 & 6,34 & 0,57 & 3,95 & 1,34 & 1,06 & 0,59 & 5,18 & 1 & & 0,183 \\
\hline Frente & ACT-013 & 68,1 & 9,48 & 7,35 & 0,50 & 3,41 & 0,94 & 0,82 & 0,56 & 4,79 & 2,05 & 76 & 4,880 \\
\hline Frente de lavra & $A C T_{-}$ & 735 & 6,95 & 6,06 & 0,28 & 2,64 & 0,54 & 0,72 & 0,39 & 3,68 & 2 & 759 & 6,272 \\
\hline Erente de lavra & $\mathrm{ACT}$ & 65,4 & 12,7 & 6,27 & 0,53 & 4,59 & 0,65 & 0,90 & 2 & 5,02 & 7 & 9 & 0,525 \\
\hline ra & & 7 & 9 , & & 0 & 2,92 & 0 & & & 1 & & 6 & 53 \\
\hline & & & 1 & & 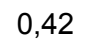 & 4 & & & & & & & \\
\hline & & & & & & & & & & & & & \\
\hline & & & & & & & & & & & & & \\
\hline & & & & & & & & & & & & & \\
\hline & & & & & 0,96 & & & 3 & & & & & \\
\hline avra & & 65,3 & 11 & 6 & 0,50 & 4,02 & 1,0 & & 58 & 5,33 & 2,04 & & 860 \\
\hline & & 64,2 & 10 & & 0 & 3,86 & 0,3 & & 57 & 5,79 & 2,46 & & 3,800 \\
\hline vra & & 71,5 & 8,4 & 6,26 & 0,28 & 3,21 & 0,47 & 6 & 0,42 & 3,97 & 3,2 & & 2,488 \\
\hline avra & 025 & 60,2 & 16,0 & 6,57 & 0,77 & 6,07 & 0,77 & 1,26 & 0,94 & 5,22 & 8 & 3272 & 0,252 \\
\hline rente de lavra & АCT-026 & 65,7 & 12,4 & 6,80 & 0,46 & 4,63 & 0,50 & 1,01 & 0,69 & 4,93 & 1. & 926 & 1,230 \\
\hline rente de lavra & АСТ-027 & 63,3 & 15,0 & 6,14 & 0,39 & 6,00 & 0,19 & 099 & 0,94 & 4,50 & 15 & 14 & 1,021 \\
\hline & ACT-02 & 69 & $11, \varsigma$ & 6,17 & 0,23 & 4,7 & 0,1 & 0,8 & . & 3,8 & & & 1,648 \\
\hline & ACT-029 & 63,0 & 14 & & 0,61 & 5,50 & 0, & 1 & 0,88 & 5,03 & & & 0,917 \\
\hline & & 69,4 & & & & & & & & 3,67 & & & 2,077 \\
\hline & & 62,9 & 14,2 & & & & & & & 5,04 & & & 0,494 \\
\hline Frente de lavra & & 62,1 & 14,9 & & & 4,77 & & & & 5,18 & & & 1,298 \\
\hline Frente de lavra & & 63,6 & & & & 5,53 & & & & & & & 0,927 \\
\hline & & 55,9 & 12,0 & & & 4,22 & & & & 7,63 & & & 1,362 \\
\hline Frente de lavra & & 63 & 15 & 6,24 & 0,67 & 5,98 & & & 0,92 & & & & 1,368 \\
\hline Frente de lavra & ACT-036 & 69,3 & 11,7 & 5,96 & 0,40 & 4,43 & 0,47 & 0,99 & 0,70 & 3,97 & 0,88 & 3848 & 0,292 \\
\hline Frente de lavra & ACT-037 & 62,1 & 14,7 & 6,93 & 0,95 & 4,93 & 0,70 & & 0,83 & 5,13 & 1,35 & 487 & 0,401 \\
\hline Frente de lavra & ACT-038 & 64,9 & 11,6 & $7,5 \mathrm{~s}$ & 0,33 & 4,46 & 0,47 & 1,06 & 0,65 & 5,30 & 1,92 & 660 & 0,704 \\
\hline & & 68,6 & 15 & & 0,20 & 5,68 & 0,11 & & 0,87 & 3,64 & & 2914 & 0,529 \\
\hline & & 56,8 & 15,5 & & & & & & 0,95 & 6,50 & & & 0,273 \\
\hline & & 70,9 & 12,0 & 5,71 & 0,18 & 3,98 & 0,19 & 0,77 & 0,57 & 4,48 & 0,53 & 3 & 0,668 \\
\hline & & 60,4 & 15,3 & 7,64 & 0,76 & 5,67 & 0,40 & & 0,88 & 5,98 & & 2386 & 0,541 \\
\hline de lavra & & 60,1 & 15,6 & 7,35 & 0,82 & 5,30 & 0,62 & 1,19 & 0,96 & 5,97 & 0,92 & 3156 & 0,324 \\
\hline Frente de lavra & АCT-044 & 61,7 & 15,4 & 7,50 & 0,61 & 5,38 & 0,26 & 1,13 & 0,88 & 4,98 & 1,04 & 3054 & 0,608 \\
\hline
\end{tabular}




\begin{tabular}{|c|c|c|c|c|c|c|c|c|c|c|c|c|c|}
\hline \multirow{2}{*}{ Proveniência } & \multirow{2}{*}{ Imostra } & \multicolumn{10}{|c|}{ Teores (\%) } & \multicolumn{2}{|c|}{ Teores (ppm) } \\
\hline & & $\mathrm{iO}_{2}$ & $\mathrm{I}_{2} \mathrm{O}_{3}$ & $\mathrm{Fe}_{2} \mathrm{O}_{3}$ & $\mathrm{Na}_{2} \mathrm{O}$ & $\mathrm{K}_{2} \mathrm{O}$ & $\mathrm{CaO}$ & MgO & $\mathrm{TiO}_{2}$ & PF & $\mathbf{S}$ & As & $\mathrm{Au}$ \\
\hline$a$ & & 2,6 & 12,9 & 756 & 0,43 & 4,81 & 0,67 & 1,09 & 0,77 & 5,55 & 2,19 & 3565 & 1,829 \\
\hline & 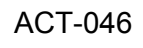 & & 11,4 & 6 & 9 & 97 & . & & 60 & 4,93 & & 3 & \\
\hline rente de lavra & 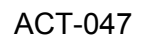 & ( & 10,2 & 3,69 & 0,19 & 3,71 & 0,03 & 5 & (1) & 3,69 & & & 42 \\
\hline Frente de lavra & АCT-048 & o, & 16,6 & 6,57 & 0,34 & 5,33 & 0,0 & 1,04 & ,98 & 4,65 & & 369 & 0,568 \\
\hline Frente de lavra & $\mathrm{ACT}$ & $00, r$ & 13,8 & 6,01 & 0,80 & 4,50 & 0,00 & & 7 & 4,69 & & 32 & 1,758 \\
\hline de lavra & ACT-050 & 7,0 & 11 & 6,39 & 37 & 4,40 & 0 , & 3 & 7 & 4,54 & & 88 & 1,465 \\
\hline Frente de lavra & ACT-051 & 67,3 & 11,5 & 6,34 & 0,57 & 4 & 0,92 & 1,00 & 0,65 & 5,15 & 8 & 122 & 0,486 \\
\hline de lavra & ACT-052 & 65,5 & 13,3 & 5,99 & 0,43 & 4,80 & 0,65 & 1,06 & 0,71 & 79 & 1,42 & 3537 & 0,314 \\
\hline Fren & ACT & 62,9 & 14 & 7,60 & 0,67 & 5,07 & 0,79 & 4 & 0,78 &, 70 & 3 & 9 & 19 \\
\hline de lavra & $A C$ & 62,3 & 14 & 7,56 & 0 & 5,30 & 0,64 & 1,09 & & 5,48 & 59 & 2 & 1,589 \\
\hline de lavra & $A C^{-}$ & 60,4 & 14,9 & 7,65 & 0,69 & 5,75 & 0,77 & & & 5,75 & & 551 & \\
\hline Fre & $A C$ & 7 & 13 & 3 & 3 & 4,67 & 0 , & 0,65 & & 5 & & 0 & 072 \\
\hline lavra & A & - & 15 & 14 & 6 & 5,74 & 0,2 & 8 & 7 & 3 & & 602 & ,711 \\
\hline lavra & $A C$ & 다. & 12 & 6 & 0,44 & 4,39 & 0 , & , & 11 & 4,92 & 1,32 & 39 & 0,604 \\
\hline vra & $\mathrm{AC}$ & 0 & 12,5 & $0,+1$ & 0,02 & 4,90 & 1,10 & 0,98 & & 4,09 & & 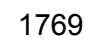 & 0,412 \\
\hline & & 65,2 & 13 & & 9 & 5 , & & & & 4,86 & & & \\
\hline & & 59,5 & & 8 & 2 & 5 & & & & 5,98 & & & \\
\hline & & 61,8 & 1 & 7, & 0 & 4 & 0,8 & 6 & 35 & 4 & & & \\
\hline Sonc & $A C$ & (01, & 14 & 7,7 & 1,12 & 4, & 0 & 1 & 0,85 & 6,18 & 0 & 0 & 587 \\
\hline Sonc & АCT-064 & 75,6 & 11,3 & 3,00 & 0,15 & 4,65 & 0,03 & 0,60 & 0,64 & 2,13 & 0 , & 2598 & 0,421 \\
\hline Sondagem & ACT-06 & 60,6 & 15 & 8,10 & 0,74 & 5,28 & 0,24 & 1,12 & 0,79 & 5,96 & 0,7 & 5 & 0,896 \\
\hline Son & $\mathrm{ACT}$ & 4 & 14 & 6,1 & 0,17 & 6,06 & 0 & 1,03 & 0,81 & 4,49 & 1, & 7 & 0 \\
\hline Son & ACT-067 & 61,8 & 14 & 7,3 & 0,19 & 6,20 & 0 & 0,98 & 0,89 & 5,04 & 1, & 1 & 4 \\
\hline Sondagem & АCT-068 & 59,3 & 14 & 7,7 & 0,51 & 5,70 & 0,7 & 1,15 & 0,87 & 5,74 & 2,2 & 2551 & 0,729 \\
\hline Sondagem & АCT-069 & 64,0 & 13,5 & 6,4 & 0,52 & 5,49 & 0,3 & 1 & 0,79 & 4,60 & 1, & 10858 & 1,892 \\
\hline Sond & АCT-070 & 60,6 & 15 & 7,1 & 0,0 & 5,81 & , & 1, & , & 5,54 & & & 1,2 \\
\hline & & . & & & & & & & & & & & \\
\hline Sondagem & & & 12,8 & & & 5,07 & & & & & & & \\
\hline Sondagem & & 64 & 13 & $r$ & 0 & 4,92 & & & & & & & 71 \\
\hline Frent & & 6 & 1 & 7,2 & s & 4 & 0 & & & $\angle$ & & & 3 \\
\hline Fre & & 73,7 & 11 & 3 & 0,16 & 4,55 & 0 , & 3 & 0,66 & 7 & & & 12,45 \\
\hline lavra & $A C$ & 69,1 & 11,2 & 5,92 & 0,53 & 4,01 & 0,54 & 0,88 & 0,60 & 4,13 & 2,36 & 1186 & 0,884 \\
\hline Frente de lavra & ACT-077 & 62,1 & 14,9 & 8,37 & 1,21 & 4,66 & 0,91 & 1,31 & 0,99 & 3,99 & 0,79 & 629 & 0,107 \\
\hline Frente de lavra & ACT-078 & 71,3 & 8,27 & 5,94 & 0,35 & 3,12 & 0,78 & 0,72 & 0,42 & 4,33 & 3,73 & 1074 & 0,593 \\
\hline Frente de lavra & ACT-079 & 65,8 & 11,1 & 6,99 & 0,45 & 4,21 & 0,97 & 1,17 & 0,64 & 5,50 & 1,27 & 2351 & 0,640 \\
\hline Frente de lavra & ACT-080 & 64,6 & 15,3 & 5,25 & 0,67 & 6,15 & 0,41 & 0,99 & 0,90 & 4,05 & 0,8 & 634 & 1,248 \\
\hline rente de lavra & ACT-081 & 64,4 & 12,0 & 8,21 & 0,58 & 3,94 & 1,1 & 1,16 & 0,70 & 4,97 & 1,1 & 2152 & 0,517 \\
\hline Frente de lavra & ACT-082 & 60,3 & 16,7 & 6,22 & 0,72 & 6,43 & 0,54 & 1,18 & 0,88 & 5,04 & 1,08 & 1831 & 0,579 \\
\hline Frente de lavra & ACT-083 & 61,5 & 15,4 & 7,98 & 0,23 & 5,59 & 0,05 & 0,96 & 0,84 & 5,87 & 0,7 & 517 & 0,852 \\
\hline Frente de lavra & ACT-084 & 62,7 & 16,4 & 6,55 & 0,26 & 5,34 & 0,04 & 0,87 & 0,88 & 5,98 & 0,43 & 381 & 0,274 \\
\hline Frente de lavra & ACT-085 & 68,7 & 17,3 & 2,60 & 0,24 & 6,85 & 0,02 & 0,77 & 1,04 & 2,11 & 0,01 & 852 & 0,197 \\
\hline Frente de lavra & ACT-086 & 72,4 & 14,3 & 2,63 & 0,20 & 5,54 & 0,03 & 0,66 & 0,89 & 3,04 & 0,01 & 921 & 0,427 \\
\hline Frente de lavra & ACT-087 & 53,1 & 13,7 & 20,8 & 0,18 & 4,93 & 0,02 & 0,68 & 0,75 & 5,00 & 0,06 & 3220 & 0,372 \\
\hline Frente de lavra & ACT-088 & 73,7 & 10,1 & 3,39 & 0,45 & 4,21 & 0,01 & 0,63 & 0,76 & 2,18 & 1,32 & 6134 & 1,483 \\
\hline
\end{tabular}




\section{APÊNCIDE 2 - Distribuições em massa e teores $(-0,50+0,020 \mathrm{~mm})$}

\begin{tabular}{|c|c|c|c|c|c|c|c|c|c|c|c|c|c|c|}
\hline \multirow{3}{*}{ Amostra } & & \multicolumn{6}{|c|}{ Teores } & \multicolumn{6}{|c|}{ Distribuições (\%) } \\
\hline & & & S (\% & & As ( & pm) & Au ppr & & s & & As & & $\mathrm{Au}$ & \\
\hline & $-0,5+0,02$ & $-0,02$ & $-0,5+0,02$ & $-0,02$ & $-0,5+0,02$ & $-0,02$ & $-0,5+0,02$ & $-0,02$ & $-0,5+0,02$ & $-0,02$ & $-0,5+0,02$ & $-0,02$ & $-0,5+0,02$ & $2-0,02$ \\
\hline CT-001 & 55,7 & 44,3 & 2,86 & 0,58 & 2163 & 367 & 1,64 & 0,12 & 86,0 & 14,0 & 88,1 & 11,9 & 94,5 & 5,45 \\
\hline CT-002 & 79,3 & 20,7 & & 0,60 & 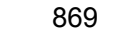 & 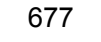 & & 0,19 & 9,8 & 10,2 & 83,1 & 16,9 & 96,5 & 3,52 \\
\hline 3 & 7 & 20,5 & 2,58 & 0,90 & 4936 & 1760 & 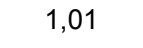 & 0,14 & ,7 & 8,3 & 1,6 & 8,4 & 8,7 & 3,33 \\
\hline ACT-004 & 59,3 & 40,7 & 2,25 & 0,50 & 6339 & 1372 & 62 & 0,14 & 5,7 & 13,3 & 87,1 & 12,9 & 4,4 & 5,60 \\
\hline ACT-005 & 74,2 & 25,8 & 2,02 & 0,56 & 834 & 190 & 1,41 & 0,20 & 1,2 & 8,8 & 92,7 & 7,3 & 95,4 & 4,64 \\
\hline ACT-006 & 64,0 & 36,0 & 1,17 & 0,34 & 2416 & 986 & 2,65 & 0,21 & 5,9 & 14,1 & 81,3 & 18,7 & 95,8 & 4,17 \\
\hline ACT-007 & 82,8 & 17,2 & 1,01 & 0,38 & 27 & 23 & 9 & 0,03 & 8 & 7,2 & 98,2 & 1,8 & 3,4 & 6,60 \\
\hline ACT-008 & 72,0 & 28,0 & 2,76 & 1,20 & 778 & 279 & 0,93 & 0,25 & 85,5 & 14,5 & 87,7 & 12,3 & 90,5 & 9,55 \\
\hline ACT-009 & 81,9 & 18,1 & 1,89 & 1,13 & 986 & 492 & 1,00 & 0,11 & 88,2 & 11,8 & 90,0 & 10,0 & 97,6 & 2,38 \\
\hline ACT-010 & 78,9 & 21,1 & 3,10 & 1,40 & 20078 & 12651 & 0,56 & 0,22 &, 2 & 10,8 & 85,6 & 14,4 & 90,6 & 9,36 \\
\hline ACT-011 & 72,8 & 27,2 & 0,80 & 0,52 & 5323 & 2974 & 1,29 & 0,20 & 7 & 1 & 82,7 & 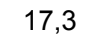 & 94,4 & 5,58 \\
\hline 12 & 72,4 & 27,6 & 1,69 & 1, & 000 & 389 & 0 & 0 & 80,4 & 6 & 4 & 6 & 93,4 & 6,58 \\
\hline 013 & 75,6 & 24,4 & -70 & 1,13 & 4 & 2704 & 2 & 0,42 & . & , & , & . & , & 2,12 \\
\hline 014 & 80,0 & 20,0 & 33 & 1,48 & 61 & 4054 & 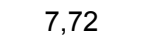 & 0,50 & 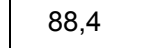 & 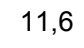 & 85,9 & 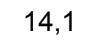 & 98,4 & 1,60 \\
\hline 015 & 75,3 & 24,7 & 9 & 1,10 & 1604 & 529 & 0,66 & 1 & 847 & 3 & 90,2 & 9,8 & 95,0 & ,98 \\
\hline ACT-016 & 76,6 & 23,4 & ,87 & 0,93 & 70 & 3246 & 12,39 & 0,68 & 2 & 1 & 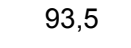 & 6,5 & 98,4 & 1,65 \\
\hline ACT-017 & 79,2 & 20,8 & 1,71 & 0,84 & 65 & 2129 & 1,00 & 0,25 & 88,6 & 11,4 & 53,8 & 46,2 & 93,9 & 6,09 \\
\hline ACT-018 & 70,0 & 30,0 & 1,83 & 0,56 & 789 & 31 & 0,68 & 0,07 & 88,5 & 11,5 & 85,4 & 14,6 & 96,0 & 4,04 \\
\hline ACT-019 & 79,4 & 20,6 & 1,98 & 0,79 & 2216 & 1149 & 1,41 & 0,27 & 6 & 9 & 88,1 & 9 & 95,3 & 4,72 \\
\hline ACT-020 & 73,3 & 26,7 & 1,15 & 0,37 & $3 \varepsilon$ & 24 & 0,81 & 0,11 & 89,5 & 10,5 & 80,9 & 1 & 95,3 & 4,66 \\
\hline ACT-021 & 76,2 & 23,8 & 1,99 & 0,69 & 736 & 587 & 60 & 0,17 & 0,2 & 9,8 & 80,0 & 0,0 & 1,9 & 8,13 \\
\hline ACT-022 & 78,4 & 21,6 & 2,32 & 1,00 & 622 & 4 & 06 & 0,14 & 9,4 & 10,6 & 98,2 & 1,8 & 6,4 & 3,58 \\
\hline ACT-023 & 8 & 18,9 & 8 & 1, & & 4 & & 6 & 8,6 & 4 & 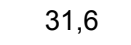 & + & 5,2 & 4,78 \\
\hline 024 & , & 2 & 3,72 & 1, & & & & 4 & 85,0 & & 86,9 & & 90,3 & 9,71 \\
\hline 025 & 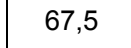 & 3 & 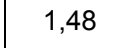 & 0 & & 8046 & & - & 85,0 & & . & & 90,3 & 9,71 \\
\hline CT-026 & 0,5 & 29,5 & 14 & 0,77 & 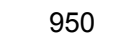 & 87 & 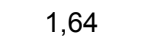 & 0,26 & 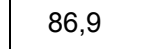 & 13 & - & 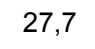 & . & 6,21 \\
\hline ACT-027 & 66,0 & 34,0 & 16 & 0,39 & 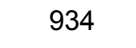 & 39 & 1,50 & 0,0 & & 8 & 8 & 0 & 97 & 2,80 \\
\hline 028 & 6,5 & 33,5 & 76 & 0,29 & & 16268 & 2 & 0,10 & 87,9 & 1 & 98 & 1 & 9 & 2,11 \\
\hline ACT-029 & 67,2 & 32,8 & 0,77 & 0,22 & 933 & 2923 & 1,32 & 0,09 & 87,7 & 12,3 & 39,5 & 60,5 & 96,9 & 3,06 \\
\hline ACT-030 & 72,5 & 27,5 & 2,19 & 0,60 & 3205 & 2161 & 2,79 & 0,20 & 90,5 & 9,5 & 79,6 & 20,4 & 97,4 & 2,62 \\
\hline ACT-031 & 72,5 & 27,5 & 1,84 & 0,58 & 2098 & 436 & 0,65 & 0,07 & 89,2 & 10,8 & 92,7 & 7,3 & 5,8 & 4,16 \\
\hline ACT-032 & 73,7 & 26,3 & ,20 & 0,62 & 42 & 908 & 70 & 0,18 & 0,9 & 1 & 51,3 & 48,7 & 6,4 & 3,62 \\
\hline ACT-033 & 72,7 & 27,3 & 1,86 & 0,7 & 802 & 000 & 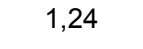 & 0,10 & , & 10 & 00 & 30,9 & 91,0 & 3,03 \\
\hline ACT-034 & 0,1 & 24,9 & 5,21 & 2,42 & 00010 & 14101 & 1,60 & 0,00 & 80 & 13 & 88,2 & 11,8 & 00,0 & 11,95 \\
\hline ACT-035 & 6,6 & 33 & 0 & 0,2 & & & & 0,1 & & $1 \varepsilon$ & 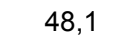 & 51,9 & 07 & 2,73 \\
\hline & 180 & 22,0 & & 0,40 & 4578 & 1258 & & 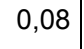 & & 00 & 928 & & 01 & 5,75 \\
\hline ACT-037 & 685 & 31,5 & 171 & 0,57 & 586 & 273 & 055 & 088 & 867 & 13,3 & 823 & 17,7 & 939 & 6,15 \\
\hline$A C$ & 75,6 & 24,4 & 8 & 0,79 & 777 & 29 & 9 & 0,12 & 89,9 & 10,1 & 89,0 & 11,0 & 5,8 & 4,20 \\
\hline ACT-039 & 72,4 & 27,6 & 2,10 & 0,57 & 3760 & 693 & 0,67 & 0,17 & 90,7 & 9,3 & 93,4 & 6,6 & 91,1 & 8,86 \\
\hline ACT-040 & 47,8 & 52,2 & 2,02 & 0,38 & 1934 & 0 & 50 & 0,06 & 82,9 & 17,1 & 100,0 & 0,0 & 88,3 & 11,66 \\
\hline ACT-041 & 54,1 & 45,9 & 0,80 & 0,21 & 1016 & 73 & 1,01 & 0,27 & 81,6 & 18,4 & 94,3 & 5,7 & 81,6 & 18,39 \\
\hline ACT-042 & 64,5 & 35,5 & 0,94 & 0,53 & 589 & 285 & 0,81 & 0,05 & 76,1 & 23,9 & 79,0 & 21,0 & 96,5 & 3,47 \\
\hline ACT-043 & 70,7 & 29,3 & 1,12 & 0,44 & 4093 & 892 & 0,41 & 0,10 & 86,1 & 13,9 & 91,7 & 8,3 & 90,7 & 9,33 \\
\hline ACT-044 & 61,3 & 38,7 & 1,52 & 0,29 & 4539 & 698 & 0,92 & 0,11 & 89,2 & 10,8 & 91,2 & 8,8 & 93,2 & 6,83 \\
\hline
\end{tabular}




\begin{tabular}{|c|c|c|c|c|c|c|c|c|c|c|c|c|c|c|}
\hline \multirow{3}{*}{ Amostra } & \multirow{2}{*}{\multicolumn{2}{|c|}{$\%$ massa }} & \multicolumn{6}{|c|}{ Teores } & \multicolumn{6}{|c|}{ Distribuições (\%) } \\
\hline & & & S (\%) & & As (pp & om) & Au pp & & s & & As & & $\mathrm{Au}$ & \\
\hline & $-0,5+0,02$ & $-0,02$ & $-0,5+0,02$ & $-0,02$ & $-0,5+0,02$ & $-0,02$ & $-0,5+0,02$ & $-0,02$ & $-0,5+0,02$ & $-0,02$ & $-0,5+0,02$ & $-0,02$ & $-0,5+0,02$ & $-0,02$ \\
\hline ACT-045 & 77,3 & 22,7 & 2,56 & 0,97 & 3820 & 2698 & 2,32 & 0,16 & 90,0 & 10,0 & 82,8 & 17,2 & 98,0 & 1,99 \\
\hline АСТ-046 & 74,4 & 25,6 & 2 & 0,79 & 2207 & 396 & 6 & 0,17 & 8 & 17,2 & 4,2 & 5,8 & 7,3 & 2,71 \\
\hline ACT-047 & 77,9 & 22,1 & 2,24 & 1,09 & 2483 & 2622 & 0,76 & 0,22 & 87,9 & 12,1 & 7,0 & 23,0 & 92,5 & 7,46 \\
\hline ACT-048 & 60,0 & 40,0 & 24 & 0,07 & 96395 & 98828 &, 67 & 0,41 & 3,8 & 16,2 & 9,4 & 40,6 & 1,3 & 28,68 \\
\hline ACT-049 & 81,1 & 18,9 & ,15 & 0,49 & 2536 & 2146 & 1 & 0,24 &, 0 & 9,0 & 3,5 & 16,5 & 97,4 & 2,57 \\
\hline ACT -050 & 74,2 & 25,8 & 1,75 & 0,75 & 2401 & 4083 & 1,91 & 0,19 & 87,0 & 13,0 & 62,8 & 37,2 & 96,7 & 3,28 \\
\hline ACT-051 & 77,2 & 22,8 & 1,36 & 0,56 & 25672 & 45 & 0,52 & 0,38 & 89,2 & 10,8 & 9 & 0 & 82,0 & 17,97 \\
\hline ACT-052 & 77,7 & 22,3 & 1,66 & 0,59 & 2184 & 4455 & 0,38 & 0,08 & 90,7 & 9,3 & 63,0 & 37,0 & 94,0 & 5,98 \\
\hline ACT-053 & 71,7 & 28,3 & 6 & 0,3 & 1 & 705 & 0,29 & 0,03 & 3 & 13,7 & 74,1 & 25,9 & 96,0 & 4,01 \\
\hline АCT-054 & 74,9 & 25,1 & 8 & 0,0 & $62 s$ & 705 & 2,12 & 0,02 & 98,5 & 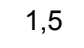 & 72,7 & 2 & 7 & 0,27 \\
\hline 055 & 76,0 & 24,0 & & 0,34 & & 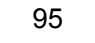 & & 0,12 & & 8,5 & & & 1,9 & 8,14 \\
\hline СТ-056 & 64,2 & 35,8 & 0,0 & 0,37 & 5643 & 1865 & S & 0,09 & . & 17,4 & 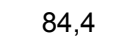 & & 7,1 & 2,87 \\
\hline ACT & 64,6 & 35,4 & 0 & 0,37 & 818 & 8 & 9 & 0,11 & 89,4 & 10,6 & 87,8 & $?$ & 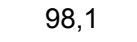 & 1,87 \\
\hline CT-058 & 71,1 & 28,9 & 1,50 & 0,88 & 182 & 1 & 0,79 & 0,15 & 80,7 & 19,3 & 74.6 & $t$ & 7 & 7,31 \\
\hline ACT-059 & 66,6 & 33,4 & 0,81 & 0,05 & 2019 & 1272 & 0,53 & 0,17 & 0 & 3,0 & 76,0 & 2 & 86,1 & 13,88 \\
\hline ACT-060 & 67,7 & 32,3 & 56 & 0,41 & 348 & 929 & 0,89 & 0,11 & 88,8 & 11,2 & 44,0 & 56, & 94,2 & 5,79 \\
\hline ACT-061 & 65,3 & 34,7 & 1,59 & 0,59 & 7778 & 814 & 1,18 & 0,25 & 83,6 & 16,4 & 94,7 & 5 , & 89,9 & 10,10 \\
\hline ACT-062 & 74,1 & 25,9 & 1,45 & 0,71 & 1517 & 311 & 5 & 0,19 & 85,3 & 14,7 & 3 & 6 , & 94,4 & 5,56 \\
\hline ACT-063 & 68,7 & 31,3 & 3 & 0,36 & 129 & 548 & 3 & 0,06 & 4 & 16,6 & 8 & 16,2 & 96,5 & 3,47 \\
\hline ACT-064 & 74,5 & 25,5 & 1,16 & 0,40 & 284 & 1872 &, 54 & 0,08 & 9,3 & 10,7 & 0 & 18,4 & 5,2 & 4,75 \\
\hline ACT-065 & 67,2 & 32,8 & 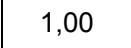 & 0,23 & 308 & 1 & 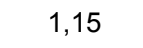 & 0,37 & 9,9 & 10,1 & 85,9 & 14,1 & , & 13,48 \\
\hline ACT-066 & , 4 & 34,6 & & 0 & & 1 & ,72 & 3 & & 1 & & & & 81 \\
\hline ACT-067 & 1 & 39,9 & & 0,42 & & & 7,66 & & & & & & & 3 \\
\hline ACT & 736 & 26,4 & 2,78 & 0,85 & - & 20 & 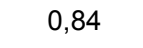 & 0,42 & 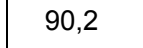 & 9,8 & 78,9 & 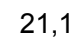 & 84,8 & 15,23 \\
\hline АСТ-069 & 77,7 & 22,3 & 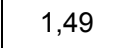 & 0,77 & 12727 & 4344 & 2,38 & 0,18 & 87,1 & 12,9 & 911 & 8,9 & 97,9 & 2,08 \\
\hline АСТ-070 & 66,2 & 33,8 & 4 & 1,08 & 18 & 85 & . & 0,20 & 6 & 20,4 & 70 & 2 & 6 & 5,37 \\
\hline АСТ-071 & 58,0 & 42,0 & 56 & 0,58 & 4760 & 766 & 0,88 & 0,19 & 8 & 14,1 & 5 & 10,5 & 86,2 & 13,77 \\
\hline ACT-072 & 76,9 & 23,1 & 2,31 & 1,13 & 17476 & 6679 & 2,69 & 0,21 & 87,2 & 12,8 & 89,7 & 10,3 & 97,7 & 2,30 \\
\hline ACT-073 & 69,8 & 30,2 & 2,32 & 0,59 & 287 & 3190 & 0,60 & 0,17 & 90,0 & 10,0 & 82,8 & 17,2 & 88,9 & 11,07 \\
\hline ACT-074 & 73,4 & 26,6 & 2,28 & 0,59 & 3230 & 1242 & 0,37 & 0,15 & 1,4 & 6 & 87,8 & 12,2 & 87,3 & 12,75 \\
\hline ACT-075 & 70,1 & 29,9 & 68 & 0,94 & 288 & 4168 & 17,12 & 1,50 & 0,8 & 19,2 & 6,1 & 13,9 & 96,4 & 3,59 \\
\hline ACT-076 & $T, 0$ & 22,4 & , 10 & 0,9 & 130 & 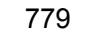 & 1,04 & 0, & & 8,5 & 00,0 & $\mathrm{~T}$ & 91,6 & 8,44 \\
\hline АСТ-077 & 6,9 & 23,1 & & 0,4 & & 48 & & 0,0 & & 11,8 & . & & 91,0 & 9,00 \\
\hline CT-078 & 0,8 & 19,2 & & 1,7 & 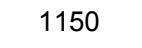 & & & 0,1 & & & & & 93,7 & 6,29 \\
\hline АСТ-079 & 159 & 24,2 & & 0,6 & 2657 & 130 & 076 & 0,27 & & 12,7 & & 1 & 89,8 & 10,17 \\
\hline CT-080 & 691 & 30,9 & 100 & 0,40 & 780 & 286 & 177 & 0,09 & 810 & 15,1 & 800 & 14,0 & 97,7 & 2,31 \\
\hline 81 & 79,0 & 21,0 & 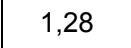 & 0,64 & 2499 & 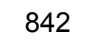 & 1 & 0,17 & ,2 & 11,8 & 8 & 8,2 & 93,0 & 6,99 \\
\hline$A C^{-}$ & 65,4 & 34,6 & 2 & 0,43 & 2401 & 54 & 87 & 0,04 & 86,3 & 13,7 & 85,8 & 14,2 & 97,8 & 2,23 \\
\hline ACT-083 & 71,3 & 28,7 & 29 & 0,39 & 7813 & 1970 & 2,03 & 0,13 & 89,1 & 10,9 & 90,8 & 9,2 & 97,4 & 2,59 \\
\hline ACT-084 & 40,3 & 59,7 & 90 & 0,12 & 726 & 149 & 0,64 & 0,03 & 83,4 & 16,6 & 76,7 & 23,3 & 93,6 & 6,42 \\
\hline ACT-085 & 31,0 & 69,0 & 0,03 & 0,01 & 2322 & 192 & 0,47 & 0,08 & 64,2 & 35,8 & 84,4 & 15,6 & 73,4 & 26,56 \\
\hline ACT-086 & 42,3 & 57,7 & 0,02 & 0,01 & 63404 & 669 & 0,67 & 0,25 & 60,6 & 39,4 & 98,6 & 1,4 & 66,2 & 33,80 \\
\hline ACT-087 & 59,9 & 40,1 & 0,0 & 0,06 & 57 & 1939 & 0,54 & 0,13 & 53,6 & 46,4 & 30,6 & 69,4 & 86,3 & 13,70 \\
\hline АCT-088 & 45,4 & 54,6 & , & 0,17 & 1024 & 96 & 1,84 & 0,03 & 86,8 & 13,2 & 89,8 & 10,2 & 97,9 & 2,11 \\
\hline
\end{tabular}




\section{APÊNCIDE 3 - Separações em líquido denso $\left(3,30 \mathrm{~g} / \mathrm{cm}^{3} ;-0,50+0,020 \mathrm{~mm}\right)$}

FL: Flutuado; AF: Afundado

\begin{tabular}{|c|c|c|c|c|c|c|c|c|c|c|c|c|c|c|}
\hline \multirow{3}{*}{ Amostra } & \multirow{2}{*}{\multicolumn{2}{|c|}{$\%$ massa }} & \multicolumn{6}{|c|}{ Teores } & \multicolumn{6}{|c|}{ Distribuições (\%) } \\
\hline & & & \multicolumn{2}{|c|}{ S (\%) } & \multicolumn{2}{|c|}{ As (ppm) } & \multicolumn{2}{|c|}{ Au ppm } & \multicolumn{2}{|c|}{$\mathbf{s}$} & \multicolumn{2}{|c|}{ As } & \multicolumn{2}{|c|}{$\mathrm{Au}$} \\
\hline & FL & AF & FL & AF & FL & AF & FL & AF & FL & AF & FL & AF & FL & AF \\
\hline ACT-001 & 78,1 & 21,9 & 0,08 & 16,1 & 41 & 9731 & 0,19 & 6,82 & 2,2 & 97,8 & 1,5 & 98,5 & 8,9 & 91,1 \\
\hline ACT-002 & 90,6 & 9,4 & 0,06 & 14,2 & 114 & 8174 & 0,19 & 12,6 & 3,8 & 96,2 & 11,9 & 88,1 & 12,5 & 87,5 \\
\hline ACT-003 & 87,8 & 12,2 & 0,18 & 29,6 & 82 & 39758 & 0,03 & 8,02 & 6,0 & 94,0 & 1,5 & 98,5 & 2,8 & 97,2 \\
\hline ACT-004 & 80,8 & 19,2 & 0,08 & 18,9 & 168 & 32344 & 0,24 & 7,42 & 2,9 & 97,1 & 2,1 & 97,9 & 12,0 & 88,0 \\
\hline ACT-005 & 88,7 & 11,3 & 0,16 & 25,2 & 124 & 6417 & 0,43 & 9,09 & 6,8 & 93,2 & 13,2 & 86,8 & 27,2 & 72,8 \\
\hline ACT-006 & 91,5 & 8,5 & 0,05 & 18,2 & 105 & 27440 & 0,24 & 28,8 & 3,6 & 96,4 & 4,0 & 96,0 & 8,1 & 91,9 \\
\hline ACT-007 & 92,9 & 7,1 & 0,16 & 12,0 & 144 & 1926 & 0,02 & 1,01 & 14,8 & 85,2 & 49,4 & 50,6 & 21,4 & 78,6 \\
\hline ACT-008 & 80,9 & 19,1 & 0,06 & 18,5 & 71 & 3767 & 0,17 & 4,18 & 1,7 & 98,3 & 7,3 & 92,7 & 14,5 & 85,5 \\
\hline ACT-009 & 90,1 & 9,9 & 0,07 & 28,5 & 150 & 8556 & 0,10 & 9,16 & 3,5 & 96,5 & 13,7 & 86,3 & 8,9 & 91,1 \\
\hline ACT-010 & 84,6 & 15,4 & 0,15 & 22,6 & 1333 & 143742 & 0,04 & 3,99 & 4,2 & 95,8 & 5,8 & 94,2 & 5,7 & 94,3 \\
\hline ACT-011 & 96,0 & 4,0 & 0,10 & 24,1 & 806 & 154653 & 0,27 & 35,0 & 12,0 & 88,0 & 14,7 & 85,3 & 20,1 & 79,9 \\
\hline ACT-012 & 91,7 & 8,3 & 0,13 & 32,9 & 402 & 1688 & 0,06 & 2,16 & 7,3 & 92,7 & 27,6 & 72,4 & 24,22 & 75,78 \\
\hline АСТ-013 & 87,1 & 12,9 & 0,09 & 25,9 & 308 & 29775 & 0,44 & 45,9 & 3 & 96 & 6,5 & 93,5 & 6,0 & 94,0 \\
\hline АСТ-014 & 88,3 & 11,7 & 0,19 & 32,6 & 508 & 70084 & 0, & 86,5 & 6 , & 93 & 7,5 & 5 & 8,5 & 91,5 \\
\hline ACT-015 & 87,2 & 12,8 & 0,07 & 24,3 & 422 & 9649 & 0,10 & 4,48 & 3 & 96,7 & 22,9 & 77,1 & 13,3 & 86,7 \\
\hline ACT-016 & 88,1 & 11,9 & 0,09 & 20,6 & 308 & 56969 & 1,06 & 163,1 & 4,2 & 95,8 & 3,8 & 96,2 & 7,5 & 92,5 \\
\hline ACT-017 & 92,5 & 7,5 & 0,08 & 29,7 & 78 & 7744 & 0,09 & 12,3 & 4,1 & 95,9 & 11,1 & 88,9 & 8,0 & 92,0 \\
\hline ACT-018 & 84,0 & 16,0 & 0,14 & 23,6 & 39 & 4726 & 0,07 & 3,92 & 6,2 & 93,8 & 4,1 & 95,9 & 8,2 & 91,8 \\
\hline ACT-019 & 89,5 & 10,5 & 0,12 & 21,8 & 303 & 18539 & 0,28 & 11,0 & 5,5 & 94,5 & 12,2 & 87,8 & 17,9 & 82,1 \\
\hline ACT-020 & 91,7 & 8,3 & 0,05 & 21,0 & 27 & 4293 & 0,26 & 6,92 & 3,9 & 96,1 & 6,6 & 93,4 & 28,9 & 71,1 \\
\hline ACT-021 & 90,2 & 9,8 & 0,09 & 27,3 & 213 & 5544 & 0,09 & 5,45 & 4,1 & 95,9 & 26,1 & 73,9 & 11,4 & 88,6 \\
\hline ACT-022 & 86,6 & 13,4 & 0,14 & 25,3 & 34 & 4423 & 0,27 & 6,20 & 5,1 & 94,9 & 4,7 & 95,3 & 21,7 & 78,3 \\
\hline ACT-023 & 88,2 & 11,8 & 0,14 & 21,7 & 30043 & 337 & 0,46 & 34,4 & 4, & 05 & 32,4 & 67,6 & 9,1 & 90,9 \\
\hline ACT-024 & 83 & 16,7 & 0,22 & 21,2 & 556 & 1713 & 0,2 & 16,9 & 4 & 9 & 61,8 & 382 & 6,7 & 93,3 \\
\hline ACT-025 & 91, & 8 & 0 & 16,3 & 1006 & 5 & 0 & 3,32 & 8 & 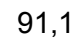 & 5,0 & 0 & 18,7 & 81,3 \\
\hline ACT-026 & 88, & 11,7 & 0,12 & 30 , & 217 & 6486 & 0,29 & S & 4 & Ju & 20,2 & 79,8 & 15,8 & 84,2 \\
\hline ACT-027 & 90,0 & 10,0 & 0,08 & 29,7 & 96 & 8499 & 0,22 & 13,0 & 3 & 96,7 & 9,2 & 90,8 & 13,5 & 86,5 \\
\hline ACT-028 & 90,0 & 10,0 & 0,08 & 15,7 & 71 & 404 & 0,34 & 33,3 & 6 & 93,1 & 27,7 & 72,3 & 13,3 & 86,7 \\
\hline ACT-029 & 90,3 & 9,7 & 0,07 & 7,2 & 1009 & 217 & 0,29 & 11,0 & 8,7 & प्रा,3 & 2,3 & 97,7 & 19,8 & 80,2 \\
\hline ACT-030 & 90,2 & 9,8 & 0,09 & 27,6 & 138 & 2315 & 0,16 & 26,9 & 3,7 & 96,3 & 3,9 & 96,1 & 5,1 & 94,9 \\
\hline ACT-031 & 87,5 & 12,5 & 0,08 & 21,5 & 18 & 16684 & 0,09 & 4,63 & 4,0 & 96,0 & 0,7 & 99,3 & 11,6 & 88,4 \\
\hline ACT-032 & 87,6 & 12,4 & 0,11 & 16,9 & 228 & 1150 & 0,41 & 10,7 & 4,5 & 95,5 & 58,3 & 41,7 & 21,4 & 78,6 \\
\hline ACT-033 & 91,3 & 8,7 & 0,12 & 33,7 & 344 & 5631 & 0,14 & 12,9 & 5,7 & 94,3 & 39,2 & 60,8 & 10,0 & 90,0 \\
\hline ACT-034 & 76,5 & 23,5 & 0,38 & 25,6 & 1057 & 178845 & 0,13 & 7,80 & 5,9 & 94,1 & 2,4 & 97,6 & 6,6 & 93,4 \\
\hline ACT-035 & 92,0 & 8,0 & 0,10 & 6,3 & 410 & 355 & 0,27 & 21,8 & 14,8 & 85,2 & 7,0 & 93,0 & 12,6 & 87,4 \\
\hline ACT-036 & 91,8 & 8,2 & 0,10 & 23,7 & 72 & 121463 & 0,04 & 8,01 & 8,6 & 91,4 & 1,4 & 98,6 & 11,3 & 88,7 \\
\hline ACT-037 & 89,5 & 10,5 & 0,10 & 27,3 & 142 & 4378 & 0,18 & 3,73 & 5,2 & 94,8 & 21,7 & 78,3 & 28,8 & 71,2 \\
\hline ACT-038 & 88,8 & 11,2 & 0,12 & 33,7 & 61 & 5631 & 0,28 & 5,78 & 4,6 & 95,4 & 7,0 & 93,0 & 27,7 & 72,3 \\
\hline ACT-039 & 85,9 & 14,1 & 0,07 & 18,9 & 1 & 26744 & 0,15 & 3,79 & 2,8 & 97,2 & 0,0 & 100,0 & 20,0 & 80,0 \\
\hline ACT-040 & 93,8 & 6,2 & 0,07 & 27,4 & 32 & 30756 & 0,05 & 7,31 & 3,0 & 97,0 & 1,5 & 98,5 & 10,2 & 89,8 \\
\hline ACT-041 & 89,7 & 10,3 & 0,04 & 9,2 & 109 & 8921 & 0,17 & 8,34 & 4,5 & 95,5 & 9,6 & 90,4 & 14,8 & 85,2 \\
\hline ACT-042 & 88,7 & 11,3 & 0,12 & 21,7 & 81 & 4567 & 0,09 & 6,40 & 10,9 & 89,1 & 12,2 & 87,8 & 10,4 & 89,6 \\
\hline ACT-043 & 86,0 & 14,0 & 0,04 & 18,6 & 137 & 1233 & 0,09 & 2,45 & 3,3 & 96,7 & 2,9 & 97,1 & 17,6 & 82,4 \\
\hline
\end{tabular}




\begin{tabular}{|c|c|c|c|c|c|c|c|c|c|c|c|c|c|c|}
\hline \multirow{3}{*}{ Amostra } & \multirow{2}{*}{\multicolumn{2}{|c|}{$\%$ massa }} & \multicolumn{6}{|c|}{ Teores } & \multicolumn{6}{|c|}{ Distribuições (\% } \\
\hline & & & \multicolumn{2}{|c|}{ S (\%) } & \multicolumn{2}{|c|}{ As (ppm) } & \multicolumn{2}{|c|}{ Au ppm } & \multicolumn{2}{|c|}{ S } & \multicolumn{2}{|c|}{ As } & \multicolumn{2}{|c|}{$\mathrm{Au}$} \\
\hline & FL & $\mathrm{AF}$ & FL & AF & FL & $A F$ & FL & & FL & $\mathrm{AF}$ & FL & $\mathrm{AF}$ & FL & AF \\
\hline ACT-044 & 88,1 & 11,9 & 0,10 & 23,2 & 12 & 38145 & 0,24 & 6,00 & 5,9 & 94,1 & 0,2 & 99,8 & 22,9 & 77,1 \\
\hline ACT-045 & 88,3 & 11,7 & 0,12 & 34,0 & 288 & 30384 & 0,58 & 15,4 & 4,2 & 95,8 & 6,7 & 93,3 & 22,2 & 77,8 \\
\hline АСТ-046 & 90,5 & 9,5 & 0,20 & 26,6 & 80 & 22408 & 0,56 & 16,3 & 14,0 & 86,0 & 3,3 & 96,7 & 24,7 & 75,3 \\
\hline ACT-047 & 94,2 & 5,8 & 0,09 & 32,7 & 621 & 32936 & 0,15 & 10,8 & 3,8 & 96,2 & 23,6 & 76,4 & 18,6 & 81,4 \\
\hline ACT-048 & 95,4 & 4,6 & 0,07 & 3,7 & 2639 & 98828 & 0,41 & 6,16 & 27,7 & 72,3 & 2,2 & 97,8 & 57,6 & 42,4 \\
\hline ACT-049 & 89,0 & 11,0 & 0,11 & 12,8 & 328 & 20326 & 0,25 & 17,1 & 8,4 & 91,6 & 11,5 & 88,5 & 10,6 & 89,4 \\
\hline ACT-050 & 88,8 & 11,2 & 0,11 & 22,3 & 1506 & 9493 & 0,17 & 15,7 & 5,7 & 94,3 & 55,7 & 44,3 & 8,1 & 91,9 \\
\hline ACT-051 & 90,9 & 9,1 & 0,08 & 14,2 & 2670 & 2670 & 0,42 & 1,45 & 5,6 & 94,4 & 0,9 & 99,1 & 74,5 & 25,5 \\
\hline ACT-052 & 87,7 & 12,3 & 0,05 & 21,6 & 1387 & 7843 & 0,01 & 3,00 & 2,6 & 97,4 & 55,7 & 44,3 & 2,4 & 97,6 \\
\hline ACT-053 & 86,6 & 13,4 & 0,07 & 14,7 & 413 & 3264 & 0,06 & 1,80 & 8,4 & 91,6 & 45,0 & 55,0 & 17,8 & 82,2 \\
\hline ACT-054 & 88,0 & 12,0 & 0,03 & 6,2 & 7054 & 771 & 0,02 & 17,5 & 3,9 & 96,1 & 1,5 & 98,5 & 0,7 & 99,3 \\
\hline ACT-055 & 86,9 & 13,1 & 0,06 & 22,1 & 30 & 5093 & 0,11 & 2,40 & 4,7 & 95,3 & 3,7 & 96,3 & 23,5 & 76,5 \\
\hline ACT-056 & 94,1 & 5,9 & 0,09 & 21,7 & 242 & 132376 & 0,21 & 34,6 & 9,2 & 90,8 & 4,1 & 95,9 & 12,7 & 87,3 \\
\hline ACT-057 & 65,5 & 34,5 & 0,09 & 7,5 & 30 & 2318 & 0,44 & 13,7 & 3,7 & 96,3 & 2,4 & 97,6 & 9,4 & 90,6 \\
\hline ACT-058 & 87,8 & 12,2 & 0,09 & 22,3 & 68 & 14437 & 0,44 & 8,13 & 5,4 & 94,6 & 3,3 & 96,7 & 23,3 & 76,7 \\
\hline ACT-059 & 93,7 & 6,3 & 0,06 & 21,3 & 163 & 29703 & 0,21 & 4,94 & 6,7 & 93,3 & 7,6 & 92,4 & 11,5 & 88,5 \\
\hline ACT-060 & 88,9 & 11,1 & 0,06 & 21,9 & 250 & 1137 & 0,07 & 7,50 & 3,4 & 96,6 & 63,7 & 36,3 & 10,0 & 90,0 \\
\hline ACT-061 & 86,6 & 13,4 & 0,15 & 11,0 & 6678 & 14913 & 0,10 & 7,19 & 8,0 & 92,0 & 25,6 & 74,4 & 10,8 & 89,2 \\
\hline ACT-062 & 88,8 & 11,2 & 0,15 & 22,3 & 89 & 14437 & 0,15 & 7,92 & 9,3 & 90,7 & 5,2 & 94,8 & 26,0 & 74,0 \\
\hline ACT-063 & 85,0 & 15,0 & 0,07 & 17,6 & 91 & 8084 & 0,34 & 7,56 & 7,2 & 92,8 & 6,0 & 94,0 & 10,7 & 89,3 \\
\hline ACT-064 & 95,4 & 4,6 & 0,06 & 12,8 & 107 & 20326 & 0,10 & 4,90 & 5,2 & 94,8 & 3,6 & 96,4 & 4,5 & 95,5 \\
\hline ACT-065 & 82,9 & 17,1 & 0,04 & 13,0 & 162 & 1304 & 0,03 & 11,2 & 3,1 & 96,9 & 4,4 & 95,6 & 7,4 & 92,6 \\
\hline ACT-066 & 90,4 & 9,6 & 0,02 & 14,3 & 31 & 87477 & 0,10 & 6,26 & 1,5 & 98,5 & 0,3 & 99,7 & 6,7 & 93,3 \\
\hline ACT-067| & 87,8 & 12,2 & 0,02 & 14,2 & 31 & 107143 & 0,05 & 6,99 & 4,4 & 95,6 & 2,2 & 97,8 & 1,7 & 98,3 \\
\hline ACT-068 & 86,8 & 13,2 & 0,04 & 24,4 & 192 & 19471 & 0,15 & 61,8 & 1,2 & 98,8 & 6,1 & 93,9 & 16,2 & 83,8 \\
\hline ACT-069 & 90,6 & 9,4 & 0,12 & 21,0 & 327 & 132892 & 0,16 & 5,33 & 7,3 & 92,7 & 2,3 & 97,7 & 6,3 & 93,7 \\
\hline ACT-070 & 89,0 & 11,0 & 0,13 & 30,5 & 82 & 1051 & 0,17 & 23,9 & 5,5 & 94,5 & 39,2 & 60,8 & 14,8 & 85,2 \\
\hline ACT-071 & 84,7 & 15,3 & 0,16 & 21,2 & 104 & 30540 & 0,30 & 14,1 & 5,2 & 94,8 & 1,9 & 98,1 & 22,2 & 77,8 \\
\hline ACT-072 & 89,0 & 11,0 & 0,24 & 19,1 & 455 & 155535 & 0,23 & 4,47 & 9,1 & 90,9 & 2,3 & 97,7 & 4,2 & 95,8 \\
\hline ACT-073 & 88,1 & 11,9 & 0,08 & 26,5 & 132 & 1436 & 0,13 & 23,5 & 3,0 & 97,0 & 40,6 & 59,4 & 17,9 & 82,1 \\
\hline ACT-074 & 90,5 & 9,5 & 0,09 & 24,8 & 178 & 32341 & 0,12 & 4,15 & 3,4 & 96,6 & 5,0 & 95,0 & 26,3 & 73,7 \\
\hline ACT-075 & 95,2 & 4,8 & 0,05 & 34,2 & 266 & 725 & 0,11 & 2,89 & 2,8 & 97,2 & 12,1 & 87,9 & 6,4 & 93,6 \\
\hline ACT-076 & 91,3 & 8,7 & 0,07 & 32,2 & 158 & 13283 & 1,16 & 333,6 & 2,3 & 97,7 & 11,1 & 88,9 & 12,1 & 87,9 \\
\hline АCT-077 & 93,4 & 6,6 & 0,12 & 12,1 & 208 & 7232 & 0,14 & 10,5 & 12,1 & 87,9 & 28,9 & 71,1 & 20,6 & 79,4 \\
\hline ACT-078 & 88,2 & 11,8 & 0,08 & 35,6 & 57 & 9325 & 0,03 & 1,52 & 1,8 & 98,2 & 4,4 & 95,6 & 12,8 & 87,2 \\
\hline АCT-079 & 86,9 & 13,1 & 0,03 & 21,2 & 106 & 19505 & 0,10 & 5,09 & 1,9 & 98,1 & 3,5 & 96,5 & 10,3 & 89,7 \\
\hline ACT-080 & 93,7 & 6,3 & 0,06 & 27,0 & 75 & 11331 & 0,09 & 5,18 & 6,0 & 94,0 & 8,9 & 91,1 & 2,6 & 97,4 \\
\hline ACT-081 & 86,3 & 13,7 & 0,05 & 17,1 & 69 & 34708 & 0,05 & 27,1 & 3,3 & 96,7 & 2,4 & 97,6 & 12,2 & 87,8 \\
\hline ACT-082 & 88,3 & 11,7 & 0,09 & 18,2 & 41 & 20256 & 0,03 & 7,19 & 5,5 & 94,5 & 1,5 & 98,5 & 3,0 & 97,0 \\
\hline ACT-083 & 72,9 & 27,1 & 0,05 & 6,6 & 272 & 3042 & 0,30 & 5,96 & 2,9 & 97,1 & 19,4 & 80,6 & 12,0 & 88,0 \\
\hline ACT-084 & 75,5 & 24,5 & 0,06 & 6,1 & 102 & 2647 & 0,16 & 2,09 & 5,5 & 94,5 & 10,6 & 89,4 & 19,5 & 80,5 \\
\hline ACT-085 & 94,1 & 5,9 & 0,00 & 0,4 & 2304 & 2599 & 0,19 & 4,93 & 9,5 & 90,5 & 6,6 & 93,4 & 38,0 & 62,0 \\
\hline ACT-086 & 97,0 & 3,0 & 0,01 & 0,5 & 921 & 294 & 0,46 & 7,37 & 25,6 & 74,4 & 1,0 & 99,0 & 67,2 & 32,8 \\
\hline ACT-087| & 54,0 & 46,0 & 0,02 & 0,1 & 567 & 578 & 0,31 & 0,80 & 26,9 & 73,1 & 53,5 & 46,5 & 31,1 & 68,9 \\
\hline ACT-088 & 89,9 & 10,1 & 0,11 & 16,9 & 449 & 104637 & 0,18 & 26,5 & 7,4 & 92,6 & 5,2 & 94,8 & 7,8 & 92,2 \\
\hline
\end{tabular}




\section{APÊNCIDE 4 - Composições mineralógicas das amostras estudadas} (fração $-0,50+0,020 \mathrm{~mm}$ )

sid: siderita, anq: anquerita; arsenop: arsenopirita; pirrot: pirrotita. outros; albita, mica, goethita, ilmenita, rutilo, zircão, cromita, monazita, FeAsO, AlFe-PbAsO, apatita.

outros sulfetos: calcopirita, esfalerita e galena.

\begin{tabular}{|c|c|c|c|c|c|c|c|c|c|c|c|c|}
\hline \multirow{2}{*}{ Amostra } & \multicolumn{8}{|c|}{$\%$ Massa } & \multicolumn{4}{|c|}{ Sulfetos normalizados (\%) } \\
\hline & quartzo & mica & sid/anq & clorita & $\begin{array}{c}\text { goet+ } \\
\text { ilm+rt| }\end{array}$ & albita & outros & $\sum$ sulf. & pirita & arsenop & pirrot & $\begin{array}{c}\text { outros } \\
\text { sulf }\end{array}$ \\
\hline ACT-001 & 42,3 & 39,2 & 8,7 & 0,8 & 2,5 & 1,9 & 0,2 & 4,5 & 78,1 & 3,8 & 3,6 & 14,5 \\
\hline ACT-002 & 60,8 & 25,6 & 4,8 & 1,3 & 0,9 & 3,0 & 0,1 & 3,4 & 69,8 & 17,7 & 6,3 & 6,2 \\
\hline АCT-003 & 48,2 & 34,4 & 4,5 & 1,4 & 1,0 & 3,8 & 0,2 & 6,4 & 48,1 & 37,3 & 12,8 & 1,9 \\
\hline ACT-004 & 41,8 & 37,2 & 7,7 & 1,6 & 2,0 & 3,1 & 1,8 & 4,7 & 51,8 & 40,6 & 3,0 & 4,6 \\
\hline АCT-005 & 41,4 & 38,3 & 4,5 & 2,2 & 1,4 & 6,9 & 1,6 & 3,6 & 74,4 & 17,5 & 5,9 & 2,2 \\
\hline ACT-006 & 68,4 & 20,9 & 3,0 & 2,1 & 1,7 & 1,2 & 0,3 & 2,4 & 41,6 & 48,3 & 2,2 & 7,8 \\
\hline ACT-007 & 44,7 & 36,8 & 1,5 & 6,6 & 0,8 & 8,9 & 0,4 & 0,2 & 73,6 & 2,9 & 20,1 & 3,5 \\
\hline ACT-008 & 40,6 & 36,5 & 9,8 & 2,4 & 2,0 & 4,5 & 0,4 & 3,9 & 84,9 & 4,0 & 10,1 & 1,0 \\
\hline АСТ-009 & 60,9 & 24,1 & 5,7 & 0,8 & 0,9 & 3,2 & 0,3 & 4,0 & 52,5 & 3,6 & 35,0 & 8,9 \\
\hline ACT-010 & 56,9 & 24,8 & 2,5 & 1,4 & 1,1 & 4,2 & 0,7 & 8,4 & 7,4 & 89,8 & 1,5 & 1,3 \\
\hline ACT-011 & 59,2 & 31,4 & 0,9 & 0,3 & 1,6 & 4,1 & 0,3 & 2,1 & 20,1 & 66,8 & 11,9 & 1,1 \\
\hline ACT-012 & 55,0 & 26,5 & 5,9 & 2,6 & 0,7 & 6,3 & 0,3 & 2,6 & 83,7 & 1,3 & 13,6 & 1,4 \\
\hline ACT-013 & 60,0 & 21,9 & 6,6 & 1,0 & 1,3 & 3,7 & 0,1 & 5,3 & 57,7 & 34,4 & 7,4 & 0,5 \\
\hline ACT-014 & 66,7 & 16,6 & 4,3 & 0,6 & 0,8 & 2,1 & 0,1 & 8,8 & 37,5 & 20,4 & 25,8 & 16,3 \\
\hline ACT-015 & 50,0 & 33,5 & 5,7 & 1,2 & 1,5 & 4,3 & 0,2 & 3,6 & 72,2 & 5,6 & 9,0 & 13,2 \\
\hline ACT-016 & 60,6 & 24,0 & 4,3 & 1,1 & 1,6 & 3,8 & 0,3 & 4,2 & 34,0 & 51,6 & 6,6 & 7,8 \\
\hline ACT-017 & 59,5 & 25,3 & 4,4 & 0,8 & 1,3 & 4,0 & 0,3 & 4,5 & 34,9 & 45,6 & 11,0 & 8,5 \\
\hline ACT-018 & 43,8 & 37,8 & 5,8 & 1,9 & 1,6 & 6,0 & 0,5 & 2,7 & 73,7 & 7,5 & 16,0 & 2,9 \\
\hline АCT-019 & 55,4 & 28,0 & 5,1 & 2,1 & 1,0 & 4,2 & 1,0 & 3,2 & 76,8 & 14,3 & 6,5 & 2,4 \\
\hline ACT-020 & 38,7 & 40,4 & 2,7 & 4,7 & 1,7 & 10,0 & 0,3 & 1,5 & 68,9 & 15,9 & 14,5 & 0,8 \\
\hline ACT-021 & 48 & 40 & 4,4 & 0,7 & 1,7 & 2,9 & 0,0 & 2,6 & 65,4 & 30,8 & 3,8 & 0,0 \\
\hline АCT-022 & 49,5 & 33,8 & 5,8 & 1,7 & 1,1 & 4,0 & 0,2 & 4,0 & 59,4 & 7,8 & 8,1 & 24,7 \\
\hline ACT-023 & 61,4 & 23,7 & 3,5 & 0,9 & 0,7 & 2,5 & 1,0 & 6,4 & 35,2 & 51,4 & 10,1 & 3,3 \\
\hline ACT-024 & 50,0 & 30,8 & 3,7 & 0,6 & 1,0 & 3,0 & 0,2 & 10,7 & 17,7 & 63,6 & 14,3 & 4,4 \\
\hline ACT-025 & 31,9 & 49,9 & 4,2 & 1,4 & 2,1 & 7,8 & 0,3 & 2,4 & 45,8 & 36,0 & 17,7 & 0,5 \\
\hline АСТ-026 & 50,2 & 32,2 & 6,0 & 0,9 & 1,5 & 5,3 & 0,2 & 3,7 & 68,9 & 13,9 & 10,9 & 6,3 \\
\hline ACT-027 & 38,4 & 48,5 & 3,8 & 1,2 & 1,6 & 3,8 & 0,2 & 2,4 & 86,8 & 8,0 & 3,8 & 1,4 \\
\hline ACT-028 & 55,3 & 32,3 & 4,6 & 0,9 & 1,4 & 3,1 & 0,2 & 2,2 & 64,9 & 27,7 & 4,7 & 2,7 \\
\hline ACT-029 & 42,8 & 37,4 & 6,5 & 1,8 & 1,8 & 7,4 & 1,2 & 1,0 & 50,4 & 28,0 & 20,0 & 1,6 \\
\hline АСТ-030 & 51,5 & 33,9 & 3,3 & 0,9 & 1,1 & 5,2 & 0,3 & 3,8 & 65,4 & 26,3 & 2,7 & 5,6 \\
\hline ACT-031 & 40,0 & 42,4 & 4,8 & 1,8 & 1,4 & 6,6 & 0,2 & 2,8 & 81,3 & 10,4 & 7,0 & 1,4 \\
\hline АCT-032 & 40,4 & 39,8 & 4,9 & 2,8 & 1,4 & 6,7 & 1,0 & 3,1 & 84,1 & 7,4 & 8,1 & 0,4 \\
\hline ACT-033 & 42,9 & 40,1 & 4,6 & 1,2 & 1,4 & 5,4 & 1,0 & 3,3 & 60,7 & 17,0 & 15,7 & 6,6 \\
\hline АCT-034 & 38,6 & 34,8 & 5,6 & 1,5 & 1,1 & 3,8 & 0,6 & 14,0 & 25,5 & 72,0 & 2,1 & 0,4 \\
\hline ACT-035 & 36,2 & 48,9 & 4,5 & 0,8 & 1,8 & 6,6 & 0,4 & 0,8 & 53,4 & 9,7 & 35,8 & 1,1 \\
\hline АCT-036 & 52,5 & 34,3 & 3,7 & 1,3 & 1,1 & 3,7 & 0,3 & 3,2 & 46,1 & 49,0 & 4,3 & 0,6 \\
\hline ACT-037 & 40,2 & 39,0 & 4,5 & 2,7 & 1,7 & 9,1 & 0,2 & 2,5 & 89,6 & 2,5 & 7,2 & 0,7 \\
\hline АCT-038 & 49,1 & 34,0 & 5,9 & 2,0 & 1,3 & 3,9 & 0,3 & 3,5 & 82,3 & 4,3 & 11,2 & 2,2 \\
\hline АCT-039 & 34,8 & 44,7 & 8,0 & 2,8 & 1,8 & 3,8 & 0,3 & 3,7 & 74,4 & 21,8 & 3,1 & 0,8 \\
\hline ACT-040 & 63,3 & 28,8 & 0,5 & 0,1 & 1,3 & 2,9 & 0,2 & 3,1 & 84,8 & 4,1 & 10,7 & 0,4 \\
\hline
\end{tabular}




\begin{tabular}{|c|c|c|c|c|c|c|c|c|c|c|c|c|}
\hline \multirow[b]{2}{*}{ Amostra } & \multicolumn{8}{|c|}{$\%$ Massa } & \multicolumn{4}{|c|}{ Sulfetos normalizados (\%) } \\
\hline & quartzo & mica & sid/anq & clorita & $\begin{array}{c}\text { goet+ } \\
\text { ilm+rtl }\end{array}$ & albita & outros & ¿sulf. & pirita & arsenop & pirrot & $\begin{array}{c}\text { outros } \\
\text { sulf }\end{array}$ \\
\hline ACT-041 & 60,1 & 27,6 & 6,5 & 0,6 & 1,6 & 2,1 & 0,3 & 1,1 & 73,1 & 19,5 & 3,3 & 4,2 \\
\hline ACT-042 & 33,9 & 45,3 & 6,5 & 1,8 & 1,5 & 9,1 & 0,3 & 1,6 & 67,7 & 4,5 & 27,5 & 0,4 \\
\hline ACT-043 & 34,1 & 43,2 & 7,9 & 1,6 & 1,5 & 9,2 & 0,4 & 2,0 & 53,9 & 32,1 & 13,4 & 0,6 \\
\hline ACT-044 & 40,7 & 39,2 & 4,8 & 4,4 & 1,3 & 7,4 & 0,3 & 1,9 & 49,8 & 28,3 & 19,8 & 2,1 \\
\hline ACT-045 & 46,1 & 35,2 & 5,3 & 3,2 & 1,1 & 3,5 & 0,2 & 5,3 & 63,0 & 21,8 & 14,3 & 1,0 \\
\hline АCT-046 & 51 & 38 & 1,9 & 0,5 & 1,2 & 3,3 & 0,9 & 3,2 & 66,7 & 27,8 & 1,8 & 3,7 \\
\hline ACT-047 & 62,4 & 30,3 & 0,1 & 0,2 & 0,8 & 1,9 & 0,2 & 4,3 & 66,9 & 24,8 & 4,5 & 3,8 \\
\hline ACT-048 & 44,3 & 35,0 & 8,4 & 1,2 & 2,1 & 7,3 & 0,3 & 1,3 & 58,2 & 13,0 & 27,9 & 0,9 \\
\hline ACT-049 & 46,0 & 34,4 & 7,5 & 0,9 & 1,3 & 7,0 & 0,2 & 2,7 & 43,4 & 37,8 & 18,4 & 0,5 \\
\hline ACT-050 & 54,4 & 28,9 & 6,1 & 0,9 & 1,3 & 3,5 & 0,2 & 4,5 & 27,9 & 56,1 & 10,2 & 5,8 \\
\hline ACT-051 & 51,5 & 30,5 & 6,8 & 0,7 & 1,1 & 6,7 & 0,4 & 2,4 & 62,5 & 14,6 & 15,9 & 6,9 \\
\hline ACT-052 & 48,5 & 33,9 & 5,9 & 0,9 & 1,3 & 3,6 & 0,3 & 5,7 & 60,4 & 25,9 & 10,3 & 3,4 \\
\hline ACT-053 & 48,7 & 38,0 & 0,1 & 5,5 & 3,0 & 4,2 & 0,3 & 0,2 & 32,7 & 59,6 & 7,4 & 0,2 \\
\hline ACT-054 & 37,4 & 41,5 & 7,1 & 1,0 & 2,0 & 9,7 & 0,6 & 0,7 & 40,9 & 21,0 & 36,9 & 1,3 \\
\hline ACT-055 & 33,6 & 46,7 & 5,6 & 1,7 & 1,6 & 9,0 & 0,3 & 1,4 & 89,8 & 2,6 & 6,9 & 0,7 \\
\hline ACT-056 & 51,9 & 35,9 & 1,2 & 0,3 & 1,4 & 7,0 & 0,1 & 2,1 & 23,6 & 62,5 & 10,4 & 3,5 \\
\hline ACT-057 & 51,4 & 32,8 & 4,8 & 0,8 & 1,4 & 7,2 & 0,2 & 1,5 & 43,7 & 43,9 & 9,5 & 2,9 \\
\hline ACT-058 & 50,3 & 32,5 & 7,2 & 1,5 & 1,6 & 4,5 & 0,2 & 2,3 & 76,3 & 19,1 & 3,8 & 0,8 \\
\hline АCT-059 & 28,6 & 47,2 & 14,6 & 1,3 & 2,7 & 3,5 & 0,2 & 1,9 & 91,9 & 1,7 & 5,6 & 0,8 \\
\hline ACT-060 & 47,7 & 35,8 & 5,8 & 0,9 & 1,6 & 5,1 & 0,2 & 2,9 & 62,0 & 29,0 & 6,7 & 2,3 \\
\hline ACT-061 & 36,1 & 42,9 & 7,6 & 1,6 & 1,9 & 7,2 & 0,4 & 2,3 & 66,4 & 13,4 & 19,4 & 0,9 \\
\hline ACT-062 & 38,8 & 32,6 & 6,4 & 3,4 & 2,0 & 13,8 & 0,3 & 2,5 & 60,0 & 4,3 & 35,5 & 0,2 \\
\hline ACT-063 & 35,6 & 36,2 & 10,5 & 1,9 & 1,7 & 12,3 & 0,2 & 1,7 & 54,2 & 15,9 & 28,9 & 0,9 \\
\hline ACT-064 & 64,1 & 30,8 & 0,2 & 0,1 & 1,1 & 1,5 & 0,1 & 2,1 & 47,7 & 45,3 & 3,1 & 3,9 \\
\hline ACT-065 & 35,5 & 40,8 & 9,8 & 1,5 & 2,4 & 7,2 & 0,3 & 2,5 & 50,8 & 45,6 & 3,5 & 0,1 \\
\hline ACT-066 & 45,5 & 42,1 & 5,0 & 0,8 & 1,4 & 2,6 & 0,2 & 2,4 & 58,6 & 35,4 & 5,1 & 0,9 \\
\hline ACT-067 & 44,8 & 37,2 & 7,0 & 0,9 & 2,2 & 4,0 & 0,3 & 3,5 & 46,7 & 49,0 & 3,9 & 0,4 \\
\hline ACT-068 & 49 & 37 & 4,4 & 0,7 & 2,0 & 3,0 & 0,3 & 3,6 & 54,0 & 43,1 & 1,6 & 1,4 \\
\hline ACT-069 & 63,1 & 32,0 & 0,3 & 0,2 & 1,0 & 1,3 & 0,1 & 2,0 & 45,7 & 47,3 & 3,9 & 3,1 \\
\hline ACT-070 & 38,1 & 41,3 & 6,0 & 1,4 & 1,8 & 7,5 & 0,4 & 3,6 & 80,8 & 11,6 & 5,5 & 2,1 \\
\hline ACT-071 & 41,3 & 39,9 & 6,4 & 1,6 & 2,0 & 4,8 & 0,4 & 3,6 & 85,6 & 7,6 & 4,0 & 2,8 \\
\hline ACT-072 & 44,6 & 34,0 & 6,5 & 1,0 & 1,1 & 5,6 & 0,4 & 6,9 & 15,2 & 54,7 & 27,4 & 2,8 \\
\hline ACT-073 & 42,2 & 37,6 & 5,2 & 3,4 & 1,6 & 7,2 & 0,4 & 2,4 & 83,6 & 8,8 & 6,6 & 0,9 \\
\hline ACT-075 & 45,2 & 34,3 & 5,9 & 5,0 & 1,4 & 4,5 & 0,8 & 3,0 & 71,3 & 22,0 & 6,3 & 0,5 \\
\hline ACT-076 & 55,3 & 29,8 & 3,7 & 2,5 & 1,0 & 4,8 & 0,3 & 2,7 & 84,1 & 6,3 & 8,6 & 0,9 \\
\hline ACT-077 & 39,5 & 36,0 & 1,6 & 6,7 & 2,0 & 12,7 & 0,2 & 1,3 & 84,8 & 9,4 & 5,0 & 0,8 \\
\hline ACT-078 & 64,8 & 21,7 & 4,5 & 0,7 & 1,0 & 2,3 & 0,2 & 4,8 & 73,2 & 3,9 & 6,9 & 15,9 \\
\hline ACT-079 & 51,8 & 30,7 & 7,5 & 1,3 & 1,2 & 3,4 & 0,4 & 3,8 & 32,6 & 19,6 & 3,7 & 44,2 \\
\hline ACT-080 & 44,4 & 39,8 & 3,3 & 0,9 & 1,3 & 8,9 & 0,2 & 1,2 & 69,7 & 5,7 & 20,6 & 4,0 \\
\hline ACT-081 & 45,4 & 34,2 & 6,1 & 5,0 & 1,4 & 4,3 & 0,7 & 2,9 & 73,1 & 20,9 & 5,3 & 0,7 \\
\hline ACT-082 & 43 & 41 & 6,3 & 1,7 & 1,7 & 4,0 & 0,3 & 2,7 & 63,9 & 31,3 & 4,2 & 0,5 \\
\hline ACT-083 & 49,3 & 26,9 & 13,9 & 1,1 & 3,6 & 3,1 & 0,2 & 1,9 & 76,5 & 11,4 & 10,6 & 1,6 \\
\hline ACT-084 & 49,6 & 31,7 & 10,8 & 0,8 & 3,2 & 2,7 & 0,2 & 1,1 & 79,8 & 17,7 & 1,6 & 0,9 \\
\hline ACT-085 & 47,0 & 45,8 & 0,0 & 0,3 & 2,9 & 3,9 & 0,1 & 0,0 & 44,0 & 47,1 & 2,3 & 6,6 \\
\hline ACT-086 & 78,3 & 16,7 & 0,1 & 0,6 & 2,1 & 2,1 & 0,1 & 0,0 & 31,0 & 16,1 & 52,9 & 0,0 \\
\hline ACT-087 & 31 & 36 & 0,0 & 14,2 & 14,9 & 1,7 & 2,1 & 0,0 & 52,8 & 19,6 & 4,0 & 23,5 \\
\hline ACT-088 & 49 & 37 & 4,5 & 0,7 & 2 & 3 & 0,3 & 3,5 & 54,3 & 42,9 & 2,9 & 0,0 \\
\hline
\end{tabular}


APÊNCIDE 5 - Estimativa da distribuição de enxofre estudadas (fração $0,50+0,020 \mathrm{~mm}$ )

\begin{tabular}{|c|c|c|c|c|c|c|}
\hline Amostra & pirita & arsenopirita & pirrotita & calcopirita & esfalerita & galena \\
\hline ACT-001 & 89,6 & 1,6 & 2,9 & 0,2 & 2,7 & 3,0 \\
\hline ACT-002 & 84,6 & 7,9 & 5,4 & 0,1 & 0,2 & 1,8 \\
\hline ACT-003 & 67,1 & 19,2 & 12,6 & 0,1 & 0,6 & 0,4 \\
\hline ACT-004 & 72,9 & 21,1 & 2,9 & 0,1 & 2,3 & 0,7 \\
\hline ACT-005 & 86,3 & 7,5 & 4,8 & 0,1 & 1,3 & 0,1 \\
\hline ACT-006 & 64,1 & 27,4 & 2,4 & 0,1 & 5,0 & 0,9 \\
\hline ACT-007 & 81,2 & 1,2 & 15,6 & 1,5 & 0,1 & 0,3 \\
\hline ACT-008 & 90,2 & 1,5 & 7,5 & 0,7 & $<0,1$ & $<0,1$ \\
\hline ACT-009 & 63,4 & 1,6 & 29,8 & 0,2 & 4,0 & 1,0 \\
\hline ACT-010 & 17,7 & 78,5 & 2,5 & $<0,1$ & 0,8 & 0,4 \\
\hline ACT-011 & 37,6 & 46,0 & 15,7 & 0,1 & 0,3 & 0,4 \\
\hline ACT-012 & 88,4 & 0,5 & 10,2 & 0,6 & 0,3 & $<0,1$ \\
\hline ACT-013 & 76,0 & 16,7 & 6,8 & 0,4 & $<0,1$ & $<0,1$ \\
\hline ACT-014 & 54,7 & 11,0 & 26,5 & 0,1 & 3,2 & 4,6 \\
\hline ACT-015 & 85,8 & 2,4 & 7,6 & 0,3 & 0,1 & 3,8 \\
\hline ACT-016 & 56,7 & 31,7 & 7,7 & 0,3 & 0,9 & 2,8 \\
\hline АCТ-017 & 55,6 & 26,8 & 12,4 & 0,1 & 3,1 & 2,1 \\
\hline ACT-018 & 82,6 & 3,1 & 12,6 & 0,1 & 1,3 & 0,2 \\
\hline ACT-019 & 87,5 & 6,0 & 5,2 & 0,6 & 0,4 & 0,3 \\
\hline ACT -020 & 80,7 & 6,8 & 11,9 & 0,3 & 0,2 & $<0,1$ \\
\hline АCT-021 & 47,7 & 18,7 & 33,6 & $<0,1$ & $<0,1$ & $<0,1$ \\
\hline ACT-022 & 75,8 & 3,7 & 7,2 & 0,2 & 8,9 & 4,2 \\
\hline ACT-023 & 56,4 & 30,4 & 11,4 & 0,2 & 0,8 & 0,9 \\
\hline ACT-024 & 33,4 & 44,2 & 19,1 & 0,7 & 1,2 & 1,3 \\
\hline ACT-025 & 63,8 & 18,5 & 17,4 & 0,2 & 0,2 & $<0,1$ \\
\hline АСТ-026 & 81,7 & 6,1 & 9,1 & 0,6 & 1,5 & 1,0 \\
\hline АСТ-027 & 93,1 & 3,1 & 2,9 & 0,4 & 0,5 & 0,1 \\
\hline ACT-028 & 81,6 & 12,9 & 4,1 & 0,4 & 0,5 & 0,5 \\
\hline ACT-029 & 66,7 & 13,7 & 18,7 & $<0,1$ & 0,7 & 0,2 \\
\hline ACT -030 & 83,1 & 12,3 & 2,5 & 0,1 & 0,5 & 1,5 \\
\hline ACT-031 & 89,7 & 4,2 & 5,4 & 0,3 & 0,1 & 0,2 \\
\hline ACT-032 & 90,7 & 2,9 & 6,2 & 0,1 & $<0,1$ & 0,1 \\
\hline ACT-033 & 75,9 & 7,8 & 13,8 & 0,3 & 0,4 & 1,8 \\
\hline ACT-034 & 47,5 & 49,4 & 2,8 & 0,1 & 0,1 & 0,1 \\
\hline ACT-035 & 64,5 & 4,3 & 30,5 & 0,3 & 0,3 & 0,1 \\
\hline ACT-036 & 68,3 & 26,8 & 4,5 & $<0,1$ & 0,3 & 0,1 \\
\hline АСТ-037 & 93,3 & 1,0 & 5,3 & 0,4 & 0,1 & $<0,1$ \\
\hline ACT-038 & 88,5 & 1,7 & 8,5 & 0,5 & 0,6 & 0,1 \\
\hline АCT-039 & 87,5 & 9,4 & 2,5 & 0,4 & 0,1 & $<0,1$ \\
\hline ACT -040 & 90,1 & 1,6 & 8,0 & 0,1 & 0,1 & 0,0 \\
\hline ACT-041 & 86,3 & 8,5 & 2,7 & 1,5 & 0,6 & 0,4 \\
\hline ACT-042 & 76,1 & 1,8 & 21,8 & 0,2 & 0,1 & \\
\hline ACT-043 & 71,4 & 15,7 & 12,5 & 0,5 & $<0,1$ & \\
\hline
\end{tabular}




\begin{tabular}{|c|c|c|c|c|c|c|}
\hline Amostra & pirita & arsenopirita & pirrotita & calcopirita & esfalerita & galena \\
\hline ACT-044 & 66,0 & 13,8 & 18,5 & 0,1 & 1,5 & $<0,1$ \\
\hline ACT-045 & 77,2 & 9,8 & 12,3 & 0,2 & 0,5 & 0,1 \\
\hline ACT-046 & 83,1 & 12,8 & 1,6 & 0,1 & 2,2 & 0,2 \\
\hline ACT-047 & 83,3 & 11,4 & 4,0 & 0,2 & 0,2 & 1,0 \\
\hline ACT-048 & 69,9 & 5,8 & 23,7 & 0,4 & 0,3 & $<0,1$ \\
\hline ACT-049 & 61,7 & 19,7 & 18,4 & $<0,1$ & $<0,1$ & 0,1 \\
\hline ACT-050 & 48,1 & 35,6 & 12,3 & 0,4 & 2,0 & 1,6 \\
\hline ACT-051 & 75,2 & 6,5 & 13,5 & 0,3 & 4,4 & 0,2 \\
\hline ACT-052 & 76,6 & 12,1 & 9,2 & 0,1 & 1,5 & 0,4 \\
\hline ACT-053 & 54,5 & 36,6 & 8,7 & 0,2 & & \\
\hline ACT-054 & 54,3 & 10,3 & 34,5 & 0,6 & 0,3 & 0,1 \\
\hline ACT-055 & 93,6 & 1,0 & 5,0 & 0,1 & 0,2 & 0,1 \\
\hline ACT-056 & 42,3 & 41,4 & 13,1 & 0,1 & 2,6 & 0,5 \\
\hline ACT-057 & 64,0 & 23,7 & 9,8 & 0,2 & 2,2 & 0,1 \\
\hline ACT-058 & 88,3 & 8,2 & 3,1 & 0,3 & $<0,1$ & 0,1 \\
\hline ACT-059 & 94,8 & 0,6 & 4,1 & 0,5 & 0,1 & $<0,1$ \\
\hline АCT-060 & 79,1 & 13,6 & 6,0 & 0,5 & 0,2 & 0,4 \\
\hline ACT-061 & 77,7 & 5,8 & 16,0 & 0,4 & 0,2 & $<0,1$ \\
\hline ACT-062 & 69,2 & 1,8 & 28,8 & 0,2 & $<0,1$ & $<0,1$ \\
\hline ACT-063 & 66,9 & 7,2 & 25,1 & 0,7 & $<0,1$ & $<0,1$ \\
\hline ACT-064 & 70,2 & 24,6 & 3,2 & 0,2 & 0,9 & 1,0 \\
\hline ACT-065 & 72,4 & 23,9 & 3,5 & $<0,1$ & 0,1 & \\
\hline ACT-066 & 77,4 & 17,2 & 4,8 & 0,3 & 0,2 & 0,1 \\
\hline АCT-067 & 69,0 & 26,6 & 4,1 & 0,1 & 0,2 & $<0,1$ \\
\hline ACT-068 & 75,5 & 22,2 & 1,6 & 0,1 & 0,4 & 0,3 \\
\hline ACT-069 & 67,7 & 25,8 & 4,1 & 0,7 & 1,4 & 0,3 \\
\hline ACT-070 & 89,8 & 4,7 & 4,3 & 0,1 & 0,7 & 0,2 \\
\hline ACT-071 & 92,4 & 3,0 & 3,1 & 0,3 & 0,9 & 0,3 \\
\hline ACT-072 & 27,4 & 36,3 & 34,8 & 0,1 & 0,5 & 1,0 \\
\hline ACT-073 & 90,8 & 3,5 & 5,1 & 0,4 & 0,2 & $<0,1$ \\
\hline ACT-074 & 79,9 & 12,5 & 4,8 & 0,3 & 1,4 & 1,0 \\
\hline АCT-075 & 84,8 & 9,6 & 5,2 & 0,3 & 0,1 & $<0,1$ \\
\hline ACT-076 & 90,6 & 2,5 & 6,5 & 0,1 & $<0,1$ & 0,2 \\
\hline АCT-077 & 92,0 & 3,8 & 3,8 & 0,3 & 0,1 & 0,1 \\
\hline ACT-078 & 86,1 & 1,7 & 5,7 & 0,4 & 2,6 & 3,5 \\
\hline АCT-079 & 50,1 & 11,1 & 4,0 & 0,1 & 29,9 & 4,8 \\
\hline ACT-080 & 78,7 & 2,4 & 16,4 & 1,5 & 0,9 & 0,2 \\
\hline АCT-081 & 86,0 & 9,1 & 4,4 & 0,3 & 0,2 & $<0,1$ \\
\hline ACT-082 & 81,3 & 14,7 & 3,8 & 0,1 & 0,2 & 0,1 \\
\hline АСТ-083 & 75,0 & 22,0 & 2,0 & $<0,1$ & $<0,1$ & $<0,1$ \\
\hline ACT-084 & 90,7 & 7,4 & 1,3 & 0,4 & 0,2 & $<0,1$ \\
\hline ACT-085 & 65,5 & 25,8 & 2,4 & 4,1 & 2,2 & \\
\hline ACT-086 & 41,8 & 8,0 & 50,2 & & & \\
\hline ACT-087 & 75,9 & 10,4 & 4,1 & & 2,0 & 7,7 \\
\hline ACT-088 & 85,9 & 4,7 & 8,4 & 0,6 & 0,3 & 0,1 \\
\hline
\end{tabular}




\section{APÊNCIDE 6 - Granulação média dos sulfetos (fração -0,50+0,020 mm)}

\begin{tabular}{|c|c|c|c|c|c|c|c|}
\hline Amostra & global & pirita & pirrotita & arsenopirita & calcopirita & esfalerita & galena \\
\hline ACT-001 & 153 & 150 & 39 & 58 & 37 & 69 & 126 \\
\hline ACT-002 & 180 & 162 & 64 & 220 & 33 & 34 & 270 \\
\hline ACT-003 & 200 & 192 & 74 & 183 & 28 & 55 & 39 \\
\hline ACT-004 & 153 & 152 & 48 & 210 & 20 & 44 & 79 \\
\hline ACT-005 & 110 & 104 & 68 & 460 & 17 & 190 & 21 \\
\hline ACT-006 & 86 & 76 & 46 & 95 & 34 & 65 & 48 \\
\hline ACT-007 & 25 & 23 & 35 & 20 & 25 & 8 & 14 \\
\hline ACT-008 & 90 & 88 & 53 & 73 & 77 & 29 & 12 \\
\hline ACT-009 & 110 & 106 & 74 & 64 & 25 & 76 & 74 \\
\hline ACT-010 & 107 & 72 & 106 & 110 & 14 & 48 & 39 \\
\hline ACT-011 & 92 & 87 & 52 & 174 & 17 & 30 & 23 \\
\hline ACT-012 & 63 & 62 & 63 & 27 & 34 & 84 & 17 \\
\hline ACT-013 & 105 & 104 & 48 & 150 & 34 & 20 & 20 \\
\hline ACT-014 & 122 & 92 & 110 & 123 & 22 & 75 & 176 \\
\hline ACT-015 & 79 & 90 & 43 & 132 & 29 & 39 & 42 \\
\hline ACT-016 & 105 & 103 & 45 & 220 & 20 & 36 & 88 \\
\hline ACT-017 & 95 & 88 & 87 & 250 & 29 & 92 & 40 \\
\hline ACT-018 & 90 & 87 & 74 & 110 & 17 & 200 & 25 \\
\hline АCT-019 & 104 & 103 & 45 & 107 & 34 & 35 & 41 \\
\hline ACT-020 & 96 & 88 & 61 & 340 & 28 & 49 & 17 \\
\hline ACT-021 & 25 & 20 & 24 & 33 & & & \\
\hline ACT-022 & 110 & 104 & 39 & 111 & 29 & 74 & 48 \\
\hline ACT-023 & 120 & 88 & 76 & 153 & 25 & 51 & 44 \\
\hline ACT-024 & 130 & 125 & 62 & 120 & 155 & 80 & 48 \\
\hline ACT-025 & 89 & 87 & 36 & 125 & 40 & 25 & 14 \\
\hline ACT-026 & 105 & 122 & 36 & 123 & 68 & 53 & 45 \\
\hline ACT-027 & 112 & 110 & 34 & 77 & 47 & 33 & 15 \\
\hline ACT-028 & 110 & 106 & 40 & 165 & 34 & 31 & 30 \\
\hline АCT-029 & 66 & 64 & 36 & 220 & 10 & 37 & 36 \\
\hline АСТ-030 & 100 & 98 & 29 & 120 & 17 & 32 & 53 \\
\hline ACT-031 & 110 & 108 & 36 & 78 & 69 & 32 & 14 \\
\hline ACT-032 & 130 & 127 & 48 & 218 & 15 & 4 & 28 \\
\hline ACT-033 & 110 & 106 & 48 & 106 & 40 & 38 & 57 \\
\hline АCT-034 & 106 & 104 & 37 & 106 & 28 & 49 & 64 \\
\hline АСТ-035 & 128 & 125 & 52 & 54 & 27 & 19 & 12 \\
\hline ACT-036 & 160 & 128 & 43 & 212 & 12 & 21 & 20 \\
\hline АCT-037 & 152 & 148 & 31 & 54 & 32 & 20 & 24 \\
\hline ACT-038 & 110 & 106 & 61 & 86 & 40 & 48 & 29 \\
\hline АCT-039 & 128 & 121 & 65 & 165 & 30 & 36 & 34 \\
\hline ACT-040 & 77 & 79 & 62 & 51 & 25 & 40 & 7 \\
\hline ACT-041 & 77 & 68 & 39 & 270 & 93 & 47 & 34 \\
\hline ACT-042 & 74 & 92 & 33 & 55 & 12 & 14 & \\
\hline
\end{tabular}




\begin{tabular}{|c|c|c|c|c|c|c|c|}
\hline Amostra & global & pirita & pirrotita & arsenopirita & calcopirita & esfalerita & galena \\
\hline ACT-043 & 106 & 91 & 46 & 180 & 42 & 12 & \\
\hline ACT-044 & 75 & 93 & 38 & 76 & 24 & 39 & 15 \\
\hline ACT-045 & 122 & 120 & 65 & 148 & 44 & 48 & 21 \\
\hline АСТ-046 & 71 & 74 & 23 & 60 & 24 & 57 & 16 \\
\hline ACT-047 & 90 & 76 & 55 & 180 & 28 & 33 & 65 \\
\hline АCТ-048 & 73 & 106 & 42 & 60 & 29 & 27 & 13 \\
\hline АСТ-049 & 87 & 130 & 52 & 88 & 17 & 13 & 41 \\
\hline ACT-050 & 91 & 65 & 46 & 180 & 78 & 42 & 33 \\
\hline ACT-051 & 93 & 104 & 55 & 185 & 40 & 68 & 29 \\
\hline ACT-052 & 178 & 152 & 79 & 189 & 57 & 38 & 30 \\
\hline АCT-053 & 61 & 46 & 20 & 94 & 8 & & \\
\hline ACT-054 & 74 & 64 & 45 & 210 & 25 & 18 & 17 \\
\hline АCT-055 & 105 & 106 & 73 & 33 & 14 & 48 & 18 \\
\hline ACT-056 & 105 & 63 & 44 & 152 & 33 & 160 & 38 \\
\hline ACT-057 & 88 & 75 & 33 & 112 & 24 & 58 & 22 \\
\hline ACT-058 & 76 & 75 & 29 & 165 & 20 & 8 & 20 \\
\hline ACT-060 & 130 & 120 & 62 & 210 & 37 & 33 & 93 \\
\hline АСТ-061 & 76 & 89 & 33 & 93 & 34 & 28 & 8 \\
\hline ACT-062 & 76 & 121 & 54 & 57 & 20 & 14 & 6 \\
\hline АCТ-063 & 88 & 107 & 44 & 91 & 37 & 7 & 6 \\
\hline ACT-064 & 90 & 88 & 45 & 107 & 30 & 39 & 109 \\
\hline ACT-065 & 128 & 110 & 34 & 150 & 8 & 14 & \\
\hline ACT-066 & 103 & 104 & 42 & 90 & 43 & 20 & 19 \\
\hline ACT-067 & 106 & 105 & 64 & 91 & 20 & 28 & 10 \\
\hline АCТ-068 & 154 & 117 & 55 & 153 & 18 & 40 & 49 \\
\hline АCT-069 & 95 & 88 & 48 & 110 & 68 & 54 & 47 \\
\hline ACT-070 & 124 & 123 & 62 & 158 & 25 & 51 & 45 \\
\hline ACT-071 & 105 & 107 & 39 & 74 & 34 & 72 & 38 \\
\hline АCT-072 & 124 & 181 & 51 & 180 & 68 & 41 & 70 \\
\hline АCТ-073 & 110 & 106 & 32 & 107 & 29 & 65 & 12 \\
\hline ACT-074 & 125 & 126 & 36 & 186 & 36 & 42 & 36 \\
\hline ACT-075 & 90 & 88 & 220 & 308 & 32 & 29 & 17 \\
\hline ACT-076 & 104 & 90 & 73 & 120 & 19 & 36 & 35 \\
\hline ACT-077 & 78 & 75 & 44 & 118 & 24 & 34 & 15 \\
\hline АСТ-078 & 77 & 90 & 64 & 91 & 40 & 51 & 38 \\
\hline АСТ-079 & 107 & 91 & 58 & 122 & 43 & 206 & 65 \\
\hline ACT-080 & 57 & 63 & 32 & 68 & 94 & 33 & 24 \\
\hline ACT-081 & 95 & 92 & 68 & 215 & 36 & 68 & 12 \\
\hline АCT-082 & 152 & 151 & 39 & 176 & 20 & 24 & 20 \\
\hline ACT-083 & 97 & 95 & 52 & 195 & 54 & 17 & 30 \\
\hline ACT-084 & 91 & 78 & 20 & 220 & 48 & 17 & 8 \\
\hline ACT-085 & 8 & 14 & 4 & 29 & 7 & 4 & \\
\hline ACT-086 & 24 & 17 & 28 & 14 & & & \\
\hline ACT-087 & 29 & 28 & 17 & 120 & & & \\
\hline АCT-083 & 189 & 160 & 55 & 150 & 18 & 42 & 50 \\
\hline
\end{tabular}


APÊNCIDE 7 - Caracterização dos grãos de ouro (fração -0,50+0,020 mm)

\begin{tabular}{|c|c|c|c|c|c|c|c|c|c|}
\hline \multirow{2}{*}{ Amostra } & \multicolumn{5}{|c|}{ Microscopia eletrônica - MEV/EDS/MLA } & \multicolumn{4}{|c|}{ Diâmetros estatísticos $(\mu \mathrm{m}) \mathrm{ECD}$} \\
\hline & seções & horas & campos & $\begin{array}{c}\text { partículas cl } \\
\mathrm{Au}\end{array}$ & $\begin{array}{c}\text { Grãos de } \\
\text { ouro }\end{array}$ & $\mathrm{D}_{05}$ & $D_{10}$ & $\mathrm{D}_{50}$ & $D_{90}$ \\
\hline ACT-001 & 2 & 5,0 & 946 & 10 & 15 & 3,3 & 5,2 & 10 & 15,2 \\
\hline АСТ-002 & 2 & 5,0 & 946 & 8 & 13 & 2,3 & 2,7 & 5,5 & 8,9 \\
\hline АCT-003 & 2 & 5,0 & 946 & 23 & 31 & 3,1 & 3,8 & 15 & 20,5 \\
\hline АСТ-004 & 2 & 5,0 & 946 & 14 & 15 & 3,6 & 6 & 15 & 20 \\
\hline АСТ-005 & 2 & 5,0 & 946 & 13 & 19 & 2,2 & 17 & 65 & 70 \\
\hline АСТ-006 & 2 & 5,0 & 946 & 39 & 54 & 3,8 & 5,6 & 15 & 25,6 \\
\hline АСТ-007 & 4 & 10,0 & 1892 & 5 & 6 & 2,6 & 3,8 & 7,5 & 10,2 \\
\hline АСТ-008 & 5 & 12,5 & 2365 & 18 & 21 & 6,5 & 17,8 & 50 & 61 \\
\hline АСТ-009 & 2 & 5,0 & 946 & 14 & 15 & 1,9 & 2,3 & 5,5 & 7,2 \\
\hline АСТ-010 & 2 & 5,0 & 946 & 14 & 17 & 1,7 & 2,1 & 4 & 7,4 \\
\hline АСТ-011 & 2 & 5,0 & 946 & 19 & 24 & 6,7 & 16,8 & 35 & 51 \\
\hline АСТ-012 & 4 & 10,0 & 1892 & 2 & 2 & 12,0 & 13,2 & 20 & 25 \\
\hline АСТ-013 & 2 & 5,0 & 946 & 8 & 10 & 4,0 & 9,2 & 25 & 30,2 \\
\hline АСТ-014 & 2 & 5,0 & 946 & 49 & 72 & 4,7 & 5,7 & 20 & 35,2 \\
\hline АСТ-015 & 2 & 5,0 & 946 & 15 & 18 & 2,3 & 3,1 & 9,5 & 10,5 \\
\hline АСТ-016 & 2 & 5,0 & 946 & 25 & 49 & 3,1 & 4,8 & 23 & 36 \\
\hline АСТ-017 & 2 & 5,0 & 946 & 16 & 33 & 9,6 & 13,7 & 35 & 60 \\
\hline АCT-018 & 5 & 12,5 & 2365 & 2 & 3 & 0,4 & 0,9 & 2 & 2,3 \\
\hline АСТ-019 & 2 & 5,0 & 946 & 14 & 20 & 3,6 & 4,2 & 11 & 14,7 \\
\hline АСТ-020 & 5 & 12,5 & 2365 & 15 & 15 & 9,4 & 18 & 50 & 61 \\
\hline ACT-021 & 5 & 12,5 & 2365 & 12 & 23 & 1,8 & 2,8 & 6 & 9,2 \\
\hline ACT-022 & 2 & 5,0 & 946 & 12 & 14 & 3,0 & 4,2 & 18 & 25,5 \\
\hline АCT-023 & 4 & 10,0 & 1892 & 31 & 51 & 5,2 & 6,2 & 24 & 30,9 \\
\hline АCT-024 & 4 & 10,0 & 1892 & 39 & 68 & 4,8 & 6,2 & 26 & 61 \\
\hline АCT-025 & 4 & 10,0 & 1892 & 14 & 21 & 1,8 & 2 & 5,7 & 7,9 \\
\hline АCT-026 & 2 & 5,0 & 946 & 23 & 24 & 2,7 & 2,8 & 9,5 & 18,3 \\
\hline АCT-027 & 2 & 5,00 & 946 & 9 & 12 & 31,0 & 36 & 65 & 86 \\
\hline АCT-028 & 5 & 12,5 & 2365 & 13 & 20 & 2,1 & 2,7 & 10 & 18,2 \\
\hline АСТ-029 & 4 & 10,0 & 1892 & 10 & 23 & 2,3 & 2,7 & 8 & 12,8 \\
\hline АСТ-030 & 2 & 5,0 & 946 & 28 & 35 & 6,2 & 9,2 & 25 & 36 \\
\hline АCT-031 & 5 & 12,5 & 2365 & 15 & 23 & 3,2 & 4,8 & 16 & 21,4 \\
\hline ACT-032 & 11 & 27,5 & 5203 & 20 & 20 & 3,7 & 5,2 & 23 & 36 \\
\hline АСТ-033 & 2 & 5,0 & 946 & 12 & 13 & 5,2 & 7,6 & 12 & 14,9 \\
\hline АCТ-034 & 2 & 5,0 & 946 & 42 & 47 & 1,7 & 1,9 & 6 & 15,6 \\
\hline АCТ-035 & 4 & 10,0 & 1892 & 9 & 10 & 6,0 & 7,2 & 25 & 31,6 \\
\hline ACT-036 & 2 & 5,0 & 946 & 11 & 14 & 2,5 & 2,9 & 4,4 & 7,8 \\
\hline АСТ-037 & 4 & 10,0 & 1892 & 12 & 12 & 3,6 & 6,8 & 25 & 31,2 \\
\hline АСТ-038 & 3 & 7,5 & 1419 & 6 & 14 & 2,6 & 2,9 & 11 & 18,3 \\
\hline АСТ-039 & 2 & 5,0 & 946 & 12 & 18 & 2,2 & 2,5 & 7,5 & 9,3 \\
\hline АСТ-040 & 2 & 5,0 & 946 & 22 & 46 & 2,4 & 2,7 & 9 & 18,4 \\
\hline АСТ-041 & 5 & 12,5 & 2365 & 4 & 4 & 5,6 & 6,8 & 23 & 30,8 \\
\hline АСТ-042 & 2 & 5,0 & 946 & 8 & 9 & 4,3 & 5,2 & 13 & 15,2 \\
\hline ACT-043 & 2 & 5,0 & 946 & 11 & 29 & 1,9 & 2,6 & 7,5 & 13,5 \\
\hline
\end{tabular}




\begin{tabular}{|c|c|c|c|c|c|c|c|c|c|}
\hline \multirow[b]{2}{*}{ Amostra } & \multicolumn{5}{|c|}{ Microscopia eletrônica - MEV/EDS/MLA } & \multicolumn{4}{|c|}{ Diâmetros estatísticos $(\mu \mathrm{m}) \mathrm{ECD}$} \\
\hline & seções & horas & campos & $\begin{array}{c}\text { partículas cl } \\
\mathrm{Au}\end{array}$ & $\begin{array}{c}\text { Grãos de } \\
\text { ouro }\end{array}$ & $\mathrm{D}_{05}$ & $\mathrm{D}_{10}$ & $\mathrm{D}_{50}$ & $\mathrm{D}_{90}$ \\
\hline ACT-044 & 2 & 5,0 & 946 & 19 & 27 & 2,6 & 3,1 & 8 & 13 \\
\hline ACT-045 & 2 & 5,0 & 946 & 57 & 70 & 2,2 & 2,9 & 15 & 30,8 \\
\hline ACT-046 & 2 & 5,0 & 946 & 13 & 18 & 5,2 & 10,2 & 25 & 26,2 \\
\hline ACT-047 & 2 & 5,0 & 946 & 24 & 31 & 2,5 & 3,1 & 9,5 & 15,1 \\
\hline ACT-048 & 11 & 27,5 & 5203 & 7 & 18 & 3,6 & 5,2 & 11 & 13 \\
\hline АCT-049 & 2 & 5,0 & 946 & 9 & 19 & 3,1 & 5,2 & 16 & 25,3 \\
\hline ACT-050 & 2 & 5,0 & 946 & 24 & 39 & 2,6 & 3,9 & 20 & 30,8 \\
\hline ACT-051 & 4 & 10,0 & 1892 & 17 & 23 & 6,1 & 8,3 & 22 & 25,3 \\
\hline ACT-052 & 2 & 5,0 & 946 & 16 & 17 & 4,3 & 5,7 & 15 & 25 \\
\hline ACT-053 & 5 & 12,5 & 2365 & 4 & 4 & 2,3 & 3,1 & 5 & 6,6 \\
\hline ACT-054 & 11 & 27,5 & 5203 & 10 & 11 & 3,4 & 3,9 & 6,2 & 9,2 \\
\hline ACT-055 & 5 & 12,5 & 2365 & 8 & 11 & 2,1 & 2,6 & 6 & 9,3 \\
\hline ACT-056 & 2 & 5,0 & 946 & 8 & 9 & 4,6 & 9,4 & 20 & 25,6 \\
\hline ACT-057 & 4 & 10,0 & 1892 & 5 & 6 & 14,0 & 22 & 27 & 34,5 \\
\hline ACT-058 & 2 & 5,0 & 946 & 17 & 26 & 2,5 & 3,8 & 9 & 15,2 \\
\hline ACT-059 & 2 & 5,0 & 946 & 8 & 9 & 5,2 & 8,7 & 20 & 26 \\
\hline ACT-060 & 2 & 5,0 & 946 & 9 & 15 & 7,9 & 17 & 25 & 30 \\
\hline ACT-061 & 4 & 10,0 & 1892 & 9 & 11 & 1,8 & 2,6 & 8,5 & 15,1 \\
\hline ACT-062 & 2 & 5,00 & 946 & 15 & 26 & 5,7 & 7 & 35 & 51 \\
\hline ACT-063 & 2 & 5,0 & 946 & 7 & 11 & 1,9 & 3,6 & 6,2 & 7,8 \\
\hline ACT-064 & 2 & 5,0 & 946 & 24 & 56 & 2,9 & 3,3 & 17 & 24 \\
\hline ACT-065 & 2 & 5,0 & 946 & 5 & 10 & 1,9 & 2,6 & 5 & 9,4 \\
\hline ACT-066 & 4 & 10,0 & 1892 & 15 & 18 & 3,6 & 4,5 & 9,5 & 13,1 \\
\hline ACT-067 & 4 & 10,0 & 1892 & 17 & 23 & 2,1 & 3,1 & 6,5 & 9,2 \\
\hline ACT-068 & 2 & 5,0 & 946 & 32 & 43 & 3,6 & 3,7 & 14 & 25,8 \\
\hline АCT-069 & 2 & 5,0 & 946 & 36 & 48 & 3,5 & 5,2 & 13 & 31,1 \\
\hline ACT-070 & 2 & 5,0 & 946 & 8 & 51 & 2,6 & 2,8 & 8 & 17,2 \\
\hline ACT-071 & 2 & 5,0 & 946 & 13 & 18 & 1,9 & 2,5 & 6 & 7,7 \\
\hline ACT-072 & 4 & 10,0 & 1892 & 25 & 46 & 2,6 & 3,5 & 15 & 36 \\
\hline ACT-073 & 2 & 5,0 & 946 & 16 & 20 & 10,2 & 11 & 32 & 36,2 \\
\hline ACT-074 & 4 & 10,0 & 1892 & 21 & 29 & 21,0 & 32 & 65 & 89,5 \\
\hline ACT-075 & 2 & 5,0 & 946 & 69 & 80 & 15,2 & 29 & 50 & 63,5 \\
\hline ACT-076 & 2 & 5,0 & 946 & 23 & 39 & 3,1 & 3,9 & 22 & 29,3 \\
\hline АCT-077 & 4 & 10,0 & 1892 & 12 & 14 & 1,9 & 2,6 & 7 & 9,3 \\
\hline ACT-078 & 4 & 10,0 & 1892 & 15 & 19 & 4,6 & 7,6 & 27 & 31,4 \\
\hline ACT-079 & 4 & 10,0 & 1892 & 13 & 18 & 8,0 & 16,5 & 45 & 61,2 \\
\hline ACT-080 & 2 & 5,0 & 946 & 7 & 14 & 0,8 & 1,3 & 2,5 & 3,9 \\
\hline ACT-081 & 2 & 5,0 & 946 & 13 & 14 & 2,2 & 2,7 & 6 & 8,9 \\
\hline ACT-082 & 4 & 10,0 & 1892 & 14 & 15 & 9,7 & 17 & 55 & 72 \\
\hline ACT-083 & 5 & 12,5 & 2365 & 4 & 5 & 3,6 & 6,8 & 12 & 15,2 \\
\hline ACT-084 & 4 & 10,0 & 1892 & 3 & 5 & 1,1 & 1,9 & 2,6 & 3,3 \\
\hline ACT-085 & 11 & 27,5 & 5203 & 5 & 5 & 61,0 & 68 & 70 & 74,6 \\
\hline ACT-086 & 4 & 10,0 & 1892 & 7 & 18 & 8,1 & 12 & 36 & 51 \\
\hline ACT-087 & 4 & 10,0 & 1892 & 2 & 4 & 8,1 & 15 & 20 & 26,4 \\
\hline ACT-088 & 2 & 5,0 & 946 & 11 & 16 & 3,1 & 3,8 & 15 & 18,6 \\
\hline
\end{tabular}




\section{APÊNCIDE 8 - Características dos grãos de ouro (fração -0,50+0,020 mm)}

\begin{tabular}{|c|c|c|c|c|c|}
\hline \multirow[t]{2}{*}{ Amostra } & \multicolumn{2}{|c|}{$\begin{array}{c}\text { Composição média dos grãos } \\
(\%)\end{array}$} & \multicolumn{3}{|c|}{ Distribuição de ouro (2D - \%) } \\
\hline & $\mathrm{Au}$ & $\mathrm{Ag}$ & Exposto & Não encapsulado & Incluso \\
\hline ACT-001 & 61,9 & 38,1 & 79,9 & 2,4 & 17,7 \\
\hline ACT-002 & 81,8 & 18,2 & 4,3 & 1,4 & 94,2 \\
\hline ACT-003 & 77,1 & 22,9 & 78,4 & & 21,6 \\
\hline ACT-004 & 74,7 & 25,3 & 95,6 & 0,9 & 3,5 \\
\hline ACT-005 & 75,8 & 24,2 & 98,1 & 0,0 & 1,9 \\
\hline ACT-006 & 67,4 & 32,6 & 89,1 & 1,1 & 9,9 \\
\hline ACT-007 & 81,1 & 18,9 & 87,3 & & 12,7 \\
\hline ACT-008 & 81,5 & 18,5 & 97,0 & 0,1 & 2,9 \\
\hline ACT-009 & 70,1 & 29,9 & 56,1 & 8,2 & 35,7 \\
\hline ACT-010 & 73,3 & 26,7 & 76,5 & 2,9 & 20,6 \\
\hline ACT-011 & 78,8 & 21,2 & 94,9 & 0,5 & 4,6 \\
\hline ACT-012 & 83,3 & 16,7 & 100,0 & & \\
\hline АCT-013 & 82,4 & 17,6 & 98,4 & & 1,6 \\
\hline ACT-014 & 66,1 & 33,9 & 94,4 & 0,5 & 5,0 \\
\hline ACT-015 & 55,8 & 44,2 & 81,7 & 3,5 & 14,8 \\
\hline ACT-016 & 87,5 & 12,5 & 18,5 & 64,4 & 17,2 \\
\hline ACT-017 & 59,6 & 40,4 & 97,5 & 1,5 & 1,0 \\
\hline ACT-018 & 68 & 32 & 52,9 & & 47,1 \\
\hline ACT-019 & 81,7 & 18,3 & 53,0 & 1,3 & 45,7 \\
\hline ACT-020 & 85,8 & 14,2 & 99,3 & 0,1 & 0,6 \\
\hline ACT-021 & 78,6 & 21,4 & 45,9 & 0,9 & 53,2 \\
\hline ACT-022 & 72,3 & 27,7 & 93,4 & & 6,6 \\
\hline АCT-023 & 84,8 & 15,2 & 80,0 & 9,5 & 10,5 \\
\hline ACT-024 & 67,7 & 32,3 & 81,5 & 0,5 & 17,9 \\
\hline ACT-025 & 77,2 & 22,8 & 16,2 & & 83,8 \\
\hline ACT-026 & 71,7 & 28,3 & 81,5 & & 18,5 \\
\hline ACT-027 & 76,6 & 23,4 & 99,8 & & 0,2 \\
\hline ACT-028 & 79,4 & 20,6 & 81,2 & & 18,8 \\
\hline ACT-029 & 81,9 & 18,1 & 74,2 & 3,7 & 22,1 \\
\hline ACT-030 & 73,5 & 26,5 & 81,8 & 1,1 & 17,1 \\
\hline ACT-031 & 81,9 & 18,1 & 51,7 & 39,0 & 9,3 \\
\hline ACT-032 & 85,8 & 14,2 & 93,0 & 1,2 & 5,8 \\
\hline ACT-033 & 62,4 & 37,6 & 60,9 & 14,7 & 24,4 \\
\hline ACT-034 & 67,2 & 32,4 & 65,8 & & 34,2 \\
\hline ACT-035 & 85,6 & 14,4 & 99,0 & 0,7 & 0,2 \\
\hline ACT-036 & 67,5 & 32,5 & 13,7 & 12,5 & 73,8 \\
\hline ACT-037 & 82,8 & 17,2 & 95,9 & & 4,1 \\
\hline ACT-038 & 69,5 & 30,5 & 90,9 & & 9,1 \\
\hline АСТ-039 & 82,4 & 17,6 & 69,3 & 23,3 & 7,4 \\
\hline ACT-040 & 77 & 23 & 63,5 & 4,1 & 32,4 \\
\hline ACT-041 & 78,1 & 22,1 & 94,9 & 5,1 & \\
\hline ACT-042 & 80,4 & 19,6 & 82,0 & & 18,0 \\
\hline ACT-043 & 85,6 & 14,4 & 6,9 & 74,2 & 18,9 \\
\hline
\end{tabular}




\begin{tabular}{|c|c|c|c|c|c|}
\hline \multirow[t]{2}{*}{ Amostra } & \multicolumn{2}{|c|}{$\begin{array}{c}\text { Composição média dos grãos } \\
(\%)\end{array}$} & \multicolumn{3}{|c|}{ Distribuição de ouro (2D - \%) } \\
\hline & $\mathrm{Au}$ & $\mathbf{A g}$ & Exposto & Não encapsulado & Incluso \\
\hline ACT-044 & 76,6 & 23,4 & 44,8 & 10,9 & 44,4 \\
\hline ACT-045 & 69,3 & 30,7 & 83,1 & 0,4 & 16,5 \\
\hline ACT-046 & 70,9 & 29,1 & 96,8 & & 3,2 \\
\hline ACT-047 & 68,3 & 31,7 & 97,3 & & 2,7 \\
\hline ACT-048 & 96,4 & 3,6 & 75,5 & 21,2 & 3,3 \\
\hline АCT-049 & 83,5 & 16,5 & 95,5 & & 4,5 \\
\hline ACT-050 & 56,9 & 43,1 & 86,3 & 6,1 & 7,6 \\
\hline ACT-051 & 81,9 & 18,1 & 96,3 & 2,2 & 1,6 \\
\hline ACT-052 & 69 & 31 & 86,0 & 7,5 & 6,6 \\
\hline АCT-053 & 74,3 & 25,7 & 45,7 & & 54,3 \\
\hline ACT-054 & 79,7 & 20,3 & 47,5 & 6,2 & 46,3 \\
\hline АCT-055 & 79,3 & 24,9 & 7,2 & & 92,8 \\
\hline АCT-056 & 84,5 & 15,5 & 94,3 & & 5,7 \\
\hline ACT-057 & 91,1 & 8,9 & 98,0 & & 2,0 \\
\hline АCT-058 & 80,2 & 19,8 & 79,4 & & 20,6 \\
\hline ACT-059 & 75,7 & 24,3 & 85,0 & 3,2 & 11,9 \\
\hline АCT-060 & 82,3 & 17,7 & 98,4 & 1,4 & 0,2 \\
\hline ACT-061 & 76 & 24 & 87,7 & & 12,3 \\
\hline ACT-062 & 83,5 & 16,5 & 8,5 & 3,9 & 87,6 \\
\hline ACT-063 & 82,3 & 17,7 & 62,3 & & 37,7 \\
\hline АCT-064 & 63,1 & 36,9 & 83,4 & & 16,6 \\
\hline ACT-065 & 78 & 22 & 5,9 & & 94,1 \\
\hline ACT-066 & 76 & 24 & 75,6 & 9,2 & 15,2 \\
\hline ACT-067 & 77,9 & 22,1 & 46,5 & 20,1 & 33,5 \\
\hline ACT-068 & 73,5 & 26,5 & 85,3 & & 14,7 \\
\hline ACT-069 & 74,8 & 25,2 & 77,6 & 1,0 & 21,4 \\
\hline ACT-070 & 69,5 & 30,5 & 47,4 & & 52,6 \\
\hline ACT-071 & 67,8 & 32,2 & 66,4 & 18,5 & 15,1 \\
\hline ACT-072 & 50,7 & 49,3 & 73,8 & 3,7 & 22,5 \\
\hline АCT-073 & 80,2 & 19,8 & 98,6 & 0,6 & 0,8 \\
\hline ACT-074 & 81,2 & 18,8 & 97,8 & 0,4 & 1,8 \\
\hline ACT-075 & 86,7 & 13,3 & 99,3 & & 0,7 \\
\hline ACT-076 & 84,5 & 15,5 & 88,6 & & 11,4 \\
\hline ACT-077 & 84,9 & 15,1 & 83,3 & 4,7 & 12,0 \\
\hline АСТ-078 & 45,9 & 54,1 & 96,4 & 1,1 & 2,5 \\
\hline АСТ-079 & 41,5 & 58,5 & 92,6 & 6,8 & 0,5 \\
\hline ACT-080 & 82,8 & 17,2 & & & 100,0 \\
\hline АCT-081 & 82,5 & 17,5 & 18,4 & & 81,6 \\
\hline ACT-082 & 72,5 & 27,5 & 97,4 & 0,1 & 2,5 \\
\hline АСТ-083 & 75,2 & 24,8 & 98,4 & & 1,6 \\
\hline АCT-084 & 92,7 & 7,3 & & & 100,0 \\
\hline ACT-085 & 82,8 & 17,2 & 76,4 & & 23,6 \\
\hline ACT-086 & 86,1 & 13,9 & 99,6 & & 0,4 \\
\hline ACT-087 & 90,4 & 9,61 & 99,6 & 0,4 & 0,0 \\
\hline ACT-088 & 70,6 & 29,4 & 94,3 & 3,9 & 1,7 \\
\hline
\end{tabular}




\section{APÊNCIDE 9 - Associações dos grãos de ouro por perímetro de contato}

(2D)

Não encapsulado: sid: siderita, anq: anquerita. Outros: albita, mica, goethita, ilmenita, rutilo, zircão, cromita, monazita, FeAsO, AIFe-PbAsO, apatita. Incluso outros: pirrotita, calcopirita, esfalerita e galena.

\begin{tabular}{|c|c|c|c|c|c|c|c|c|c|c|}
\hline \multirow{2}{*}{ Amostra } & \multirow{2}{*}{$\begin{array}{c}\text { exposto } \\
\text { (\%) }\end{array}$} & \multicolumn{6}{|c|}{ Não encapsulado (\%) } & \multicolumn{3}{|c|}{ Incluso (\%) } \\
\hline & & pirita & arsenopirita & quartzo & clorita & anq+sid & outros & pirita & arsenopirita & outros \\
\hline ACT-001 & 80,1 & 1,7 & & & & 0,7 & & 6,7 & 10,8 & \\
\hline ACT-002 & 4,3 & & & & 0,5 & & 0,4 & 47,5 & 47,2 & \\
\hline ACT-003 & 78,4 & & & & & & & 16,4 & 5,2 & \\
\hline ACT-004 & 95,4 & & & & 0,4 & 0,3 & 0,3 & 2,3 & 1,3 & \\
\hline ACT-005 & 98,2 & & & & & & & 1,2 & 0,7 & \\
\hline ACT-006 & 88,5 & & & 0,6 & 0,4 & & $<0,1$ & 9,4 & 1,0 & \\
\hline ACT-007 & 87,4 & & & & & & & 12,6 & & \\
\hline ACT-008 & 96,9 & & & 0,1 & & & 0,1 & 2,0 & & 1,0 \\
\hline ACT-009 & 55,9 & & & 5,9 & & & 2,2 & 30,3 & 5,7 & \\
\hline ACT-010 & 74,1 & & & 2,3 & 1,2 & & & & 22,4 & \\
\hline ACT-011 & 94,9 & & & & 0,4 & & 0,1 & & 4,3 & 0,3 \\
\hline ACT-012 & 100,0 & & & & & & & & & \\
\hline ACT-013 & 98,5 & & & & & & & 0,9 & 0,7 & \\
\hline ACT-014 & 94,1 & & & 0,2 & 0,1 & & 0,2 & 2,4 & 3,0 & \\
\hline ACT-015 & 82,0 & & & 2,0 & & & 1,3 & 2,6 & 12,0 & \\
\hline ACT-016 & 18,5 & & 2,1 & 0,6 & & & 61,7 & 1,9 & 2,2 & 13,1 \\
\hline ACT-017 & 97,5 & & 0,0 & 0,7 & 0,4 & & 0,4 & 0,4 & 0,7 & \\
\hline ACT-018 & 52,9 & & & & & & & 47,1 & & \\
\hline ACT-019 & 53,0 & & & 1,1 & & & 0,2 & 19,6 & 26,1 & \\
\hline ACT-020 & 99,3 & & & $<0,1$ & & & $<0,1$ & 0,6 & & \\
\hline ACT-021 & 45,9 & & & 0,6 & & & 0,3 & 25,8 & 27,4 & \\
\hline ACT-022 & 92,9 & & & 0,3 & & & 0,2 & 0,9 & 5,7 & \\
\hline ACT-023 & 80,0 & 5,1 & & & & 4,2 & 0,2 & 0,4 & 6,4 & 3,8 \\
\hline ACT-024 & 81,5 & 0,1 & & & 0,4 & & 0,1 & 0,9 & 17,0 & \\
\hline ACT-025 & 16,2 & & & & & & & 71,0 & 12,8 & \\
\hline ACT-026 & 81,5 & & & & & & & 14,8 & 3,7 & \\
\hline ACT-027 & 99,8 & & & & & & & 0,2 & & \\
\hline ACT-028 & 81,2 & & & & & & & 11,1 & 7,7 & \\
\hline АСТ-029 & 74,2 & & & & 2,9 & 0,8 & & 20,6 & 1,5 & \\
\hline ACT-030 & 81,8 & & & 0,3 & 0,1 & 0,5 & 0,3 & 1,9 & 6,2 & 9,0 \\
\hline ACT-031 & 51,7 & & & 14,6 & 16,8 & & 7,7 & 7,5 & 1,8 & \\
\hline ACT-032 & 93,0 & & & 0,9 & & & 0,3 & 5,5 & 0,3 & \\
\hline ACT-033 & 60,9 & & & & 13,1 & 1,6 & & 2,4 & 22,0 & \\
\hline ACT-034 & 65,8 & & & 6,4 & 0,7 & & 2,8 & 1,7 & 22,5 & \\
\hline ACT-035 & 99,0 & & & & & & 0,7 & & 0,2 & \\
\hline ACT-036 & 13,7 & & & 10,0 & & & 2,5 & 25,1 & 48,7 & \\
\hline ACT-037 & 95,9 & & & & & & & 2,4 & 0,7 & 0,9 \\
\hline ACT-038 & 90,9 & & & & & & & 7,3 & 1,8 & \\
\hline ACT-039 & 69,3 & 10,7 & & 12,6 & & & & 5,4 & 2,0 & \\
\hline ACT-040 & 63,5 & & & 2,6 & 0,2 & & 1,3 & 20,4 & 12,0 & \\
\hline ACT-041 & 94,9 & & & & & & & & 5,1 & \\
\hline ACT-042 & 82,0 & & & & & & & 16,6 & 1,4 & \\
\hline
\end{tabular}




\begin{tabular}{|c|c|c|c|c|c|c|c|c|c|c|}
\hline \multirow{2}{*}{ Amostra } & \multirow{2}{*}{$\begin{array}{c}\text { exposto } \\
\text { (\%) }\end{array}$} & \multicolumn{6}{|c|}{ Não encapsulado (\%) } & \multicolumn{3}{|c|}{ Incluso (\%) } \\
\hline & & pirita & arsenopirita & quartzo & clorita & anq+sid & outros & pirita & arsenopirita & outros \\
\hline ACT-043 & 6,9 & 0,9 & 2,6 & & & 10,5 & 60,4 & 6,8 & 4,6 & 7,3 \\
\hline ACT-044 & 44,8 & & & 2,6 & 5,3 & & 3,0 & 4,8 & 39,6 & \\
\hline ACT-045 & 83,1 & & & 0,3 & & & 0,1 & 8,5 & 8,0 & \\
\hline ACT-046 & 96,8 & & & & & & & 1,4 & 1,4 & 0,3 \\
\hline ACT-047 & 97,3 & & & & & & & 0,6 & 2,0 & \\
\hline ACT-048 & 75,5 & & 7,5 & & 10,3 & & 3,4 & & & 3,3 \\
\hline ACT-049 & 95,5 & & & & & & & 3,6 & 0,8 & \\
\hline ACT-050 & 84,4 & & & 3,4 & & & 2,7 & 6,1 & 1,5 & 1,9 \\
\hline ACT-051 & 96,3 & & & 0,3 & 1,5 & & 0,4 & 1,0 & 0,6 & \\
\hline ACT-052 & 86,0 & 1,3 & 0,2 & & 2,2 & 2,0 & 1,7 & & 6,6 & \\
\hline ACT-053 & 45,7 & & & & & & & 48,3 & 6,0 & \\
\hline ACT-054 & 47,5 & 3,5 & & & 2,7 & & & 11,2 & 35,1 & \\
\hline ACT-055 & 7,2 & & & & & & & 83,5 & 9,3 & \\
\hline ACT-056 & 94,3 & & & & & & & & 5,7 & \\
\hline ACT-057 & 98,0 & & & & & & & 1,2 & 0,8 & \\
\hline ACT-058 & 79,4 & & & & & & & 5,5 & 15,1 & \\
\hline ACT-059 & 85,0 & & & & 2,3 & & 0,9 & 0,7 & 11,2 & \\
\hline ACT-060 & 98,4 & 0,6 & 0,5 & & 0,2 & 0,1 & & & 0,2 & \\
\hline ACT-061 & 87,7 & & & & & & & 5,5 & 6,8 & \\
\hline ACT-062 & 8,5 & & & 2,9 & 0,2 & & 0,8 & 87,6 & & \\
\hline ACT-063 & 62,8 & & & & & & & 14,9 & 22,3 & \\
\hline ACT-064 & 83,4 & & & 0,7 & 0,2 & & 0,7 & 4,2 & 10,7 & \\
\hline ACT-065 & 5,9 & & & & 9,8 & 6,3 & & 64,4 & 13,7 & \\
\hline ACT-066 & 75,6 & & 0,3 & 6,8 & 0,2 & & 2,0 & & 15,2 & \\
\hline ACT-067 & 46,5 & & 0,9 & 5,5 & 11,5 & 1,5 & 0,6 & 31,5 & 2,0 & \\
\hline ACT-068 & 85,3 & & 0,7 & 2,6 & 1,3 & & 0,7 & 4,0 & 5,6 & \\
\hline ACT-069 & 77,6 & & $<0,1$ & & 0,4 & & 0,6 & 1,3 & 20,0 & \\
\hline ACT-070 & 30,3 & 6,0 & 7,1 & & 0,9 & & 3,1 & 2,8 & 49,8 & \\
\hline ACT-071 & 73,8 & 1,7 & & & 0,3 & & 1,6 & 7,7 & 14,8 & \\
\hline ACT-072 & 66,4 & 0,2 & 0,7 & 10,4 & & 0,7 & 6,5 & 9,6 & 0,7 & 4,9 \\
\hline АCT-073 & 98,6 & & $<0,1$ & 0,4 & 0,2 & & $<0,1$ & 0,2 & 0,5 & \\
\hline ACT-074 & 97,8 & & & 0,1 & 0,2 & 0,1 & $<0,1$ & 0,7 & 1,0 & 0,1 \\
\hline ACT-075 & 99,3 & & & & & & & 0,4 & 0,1 & 0,2 \\
\hline ACT-076 & 88,6 & & & & & & & 10,9 & 0,5 & \\
\hline ACT-077 & 83,3 & & & 2,9 & & & 1,8 & 12,0 & & \\
\hline ACT-078 & 96,4 & & & 0,8 & & & 0,3 & 2,3 & & 0,1 \\
\hline ACT-079 & 92,6 & & & 2,6 & 1,8 & & 2,5 & 0,4 & 0,1 & \\
\hline ACT -080 & & & & & & & & 5,5 & 94,5 & \\
\hline ACT-081 & 18,4 & & 6,7 & 6,3 & 7,9 & & 9,9 & 35,1 & 15,8 & \\
\hline ACT-082 & 97,4 & & & $<0,1$ & & & $<0,1$ & 2,2 & 0,3 & \\
\hline ACT-083 & 98,4 & & & & & & & & 1,6 & \\
\hline ACT-084 & & & & & & & & & 100,0 & \\
\hline ACT-085 & 100,0 & & & & & & & & $<0,1$ & \\
\hline ACT-086 & 99,6 & & & & & & & 0,4 & & \\
\hline ACT-087 & 99,6 & & & & & & 0,4 & & & \\
\hline ACT-088 & 94,3 & & 1,6 & & 2,4 & & & & 1,7 & \\
\hline
\end{tabular}


APÊNCIDE 10 - Imagens de elétrons retroespalhados - Grãos de ouro acessível

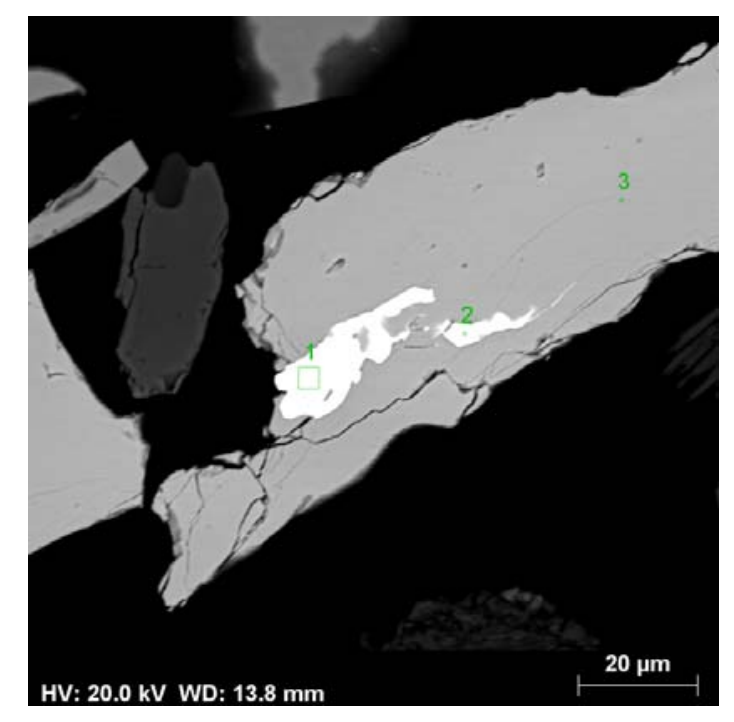

\begin{tabular}{cccccc}
\hline \multicolumn{7}{c}{ Teores (\% em massa) } \\
EDS & $\mathbf{S}$ & Fe & As & Ag & Au \\
\hline 1 & & & & 26,3 & 73,7 \\
2 & & & & 28,4 & 71,6 \\
3 & 19,2 & 40,3 & 40,4 & & \\
\hline
\end{tabular}

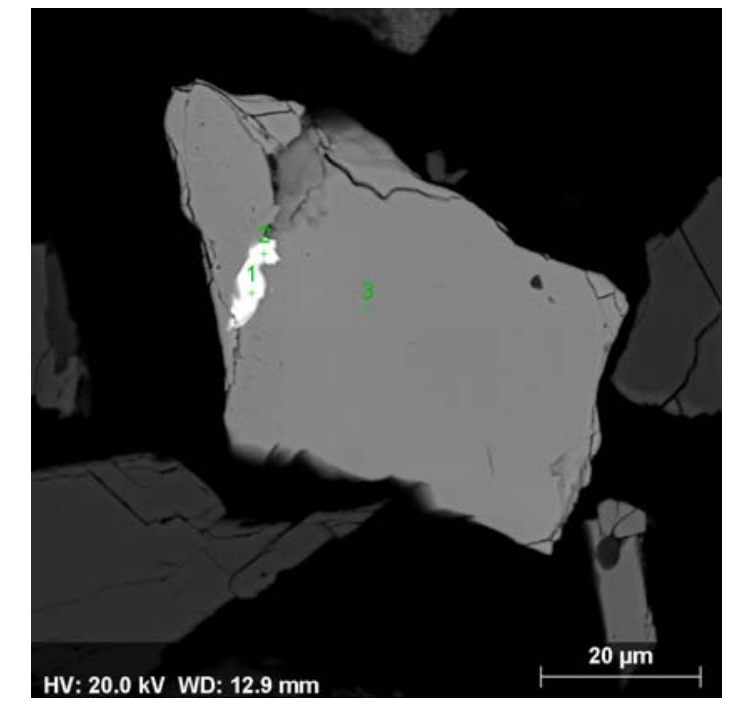

\begin{tabular}{cccccc}
\hline & \multicolumn{5}{c}{ Teores (\% em massa) } \\
EDS & $\mathbf{S}$ & Fe & As & Ag & Au \\
\hline 1 & & & & 25,1 & 74,9 \\
2 & & & & 28,3 & 71,7 \\
3 & 18,0 & 38,9 & 43,1 & & \\
\hline
\end{tabular}

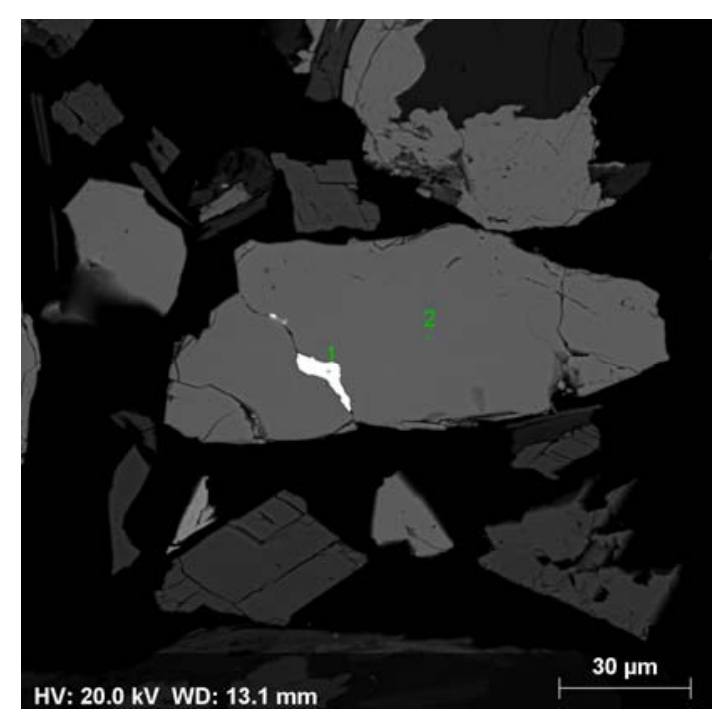

\begin{tabular}{ccccc}
\hline & \multicolumn{4}{c}{ Teores (\% em massa) } \\
EDS & S & Fe & Ag & Au \\
\hline 1 & & & 19,6 & 80,4 \\
2 & 46,5 & 53,5 & & \\
\hline
\end{tabular}

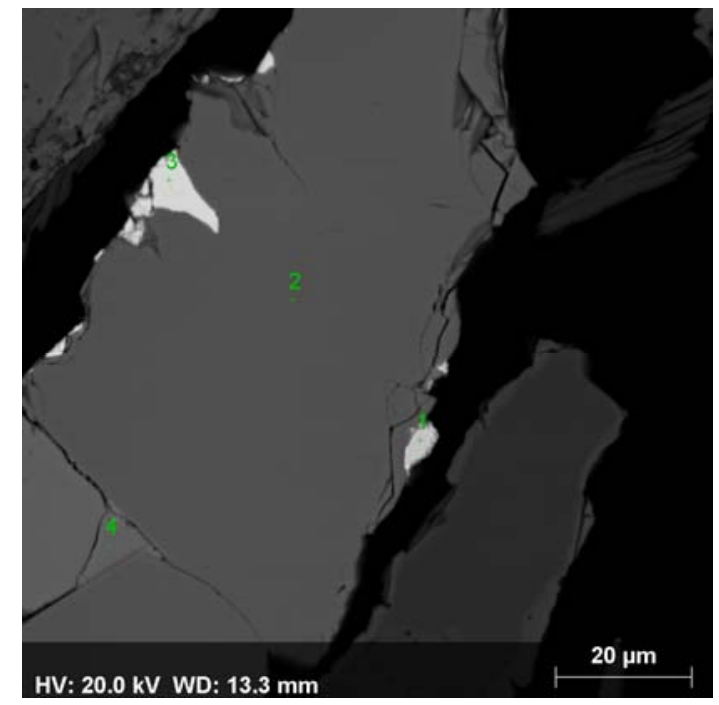

\begin{tabular}{ccccccc}
\hline \multicolumn{7}{c}{ Teores (\% em massa) } \\
EDS & $\mathbf{S}$ & $\mathrm{Fe}$ & $\mathbf{C u}$ & $\mathbf{A g}$ & $\mathbf{A u}$ & $\mathbf{P b}$ \\
\hline 1 & & & & 72,7 & 27,3 & \\
2 & 45,5 & 54,5 & & & & \\
3 & 14,8 & & & & & 85,2 \\
4 & 32,3 & 36,9 & 30,8 & & & \\
\hline
\end{tabular}


APÊNCIDE 11 - Imagens de elétrons retroespalhados - Grãos de ouro não encapsulado
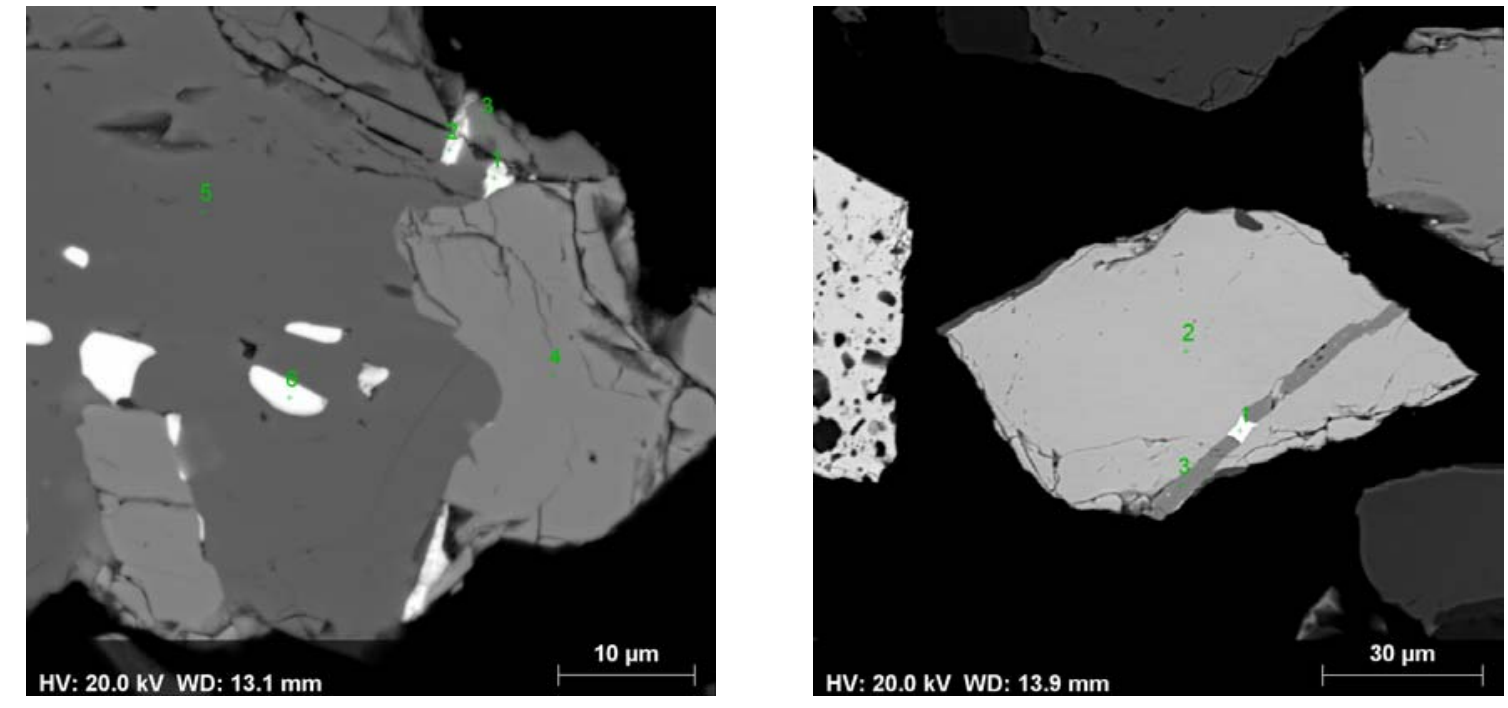

\begin{tabular}{cccccccc}
\hline \multicolumn{7}{c}{ Teores (\% em massa) } \\
EDS & $\mathbf{S}$ & Fe & Cu & As & Ag & Au & Pb \\
\hline 1 & & & & & 37,7 & 62,3 & \\
2 & 15,4 & & & & & & 84,6 \\
3 & 32,7 & 35,8 & 31,6 & & & & \\
4 & 18,9 & 39,0 & & 42,1 & & & \\
5 & 45,2 & 54,8 & & & & & \\
6 & 11,1 & & & & & & 88,9 \\
\hline
\end{tabular}

\begin{tabular}{cccccc}
\hline \multicolumn{6}{c}{ Teores (\% em massa) } \\
EDS & S & Fe & As & Ag & Au \\
\hline 1 & & & & 10,5 & 89,5 \\
2 & 19,2 & 38,9 & 41,9 & & \\
3 & 44,8 & 55,2 & & & \\
\hline
\end{tabular}
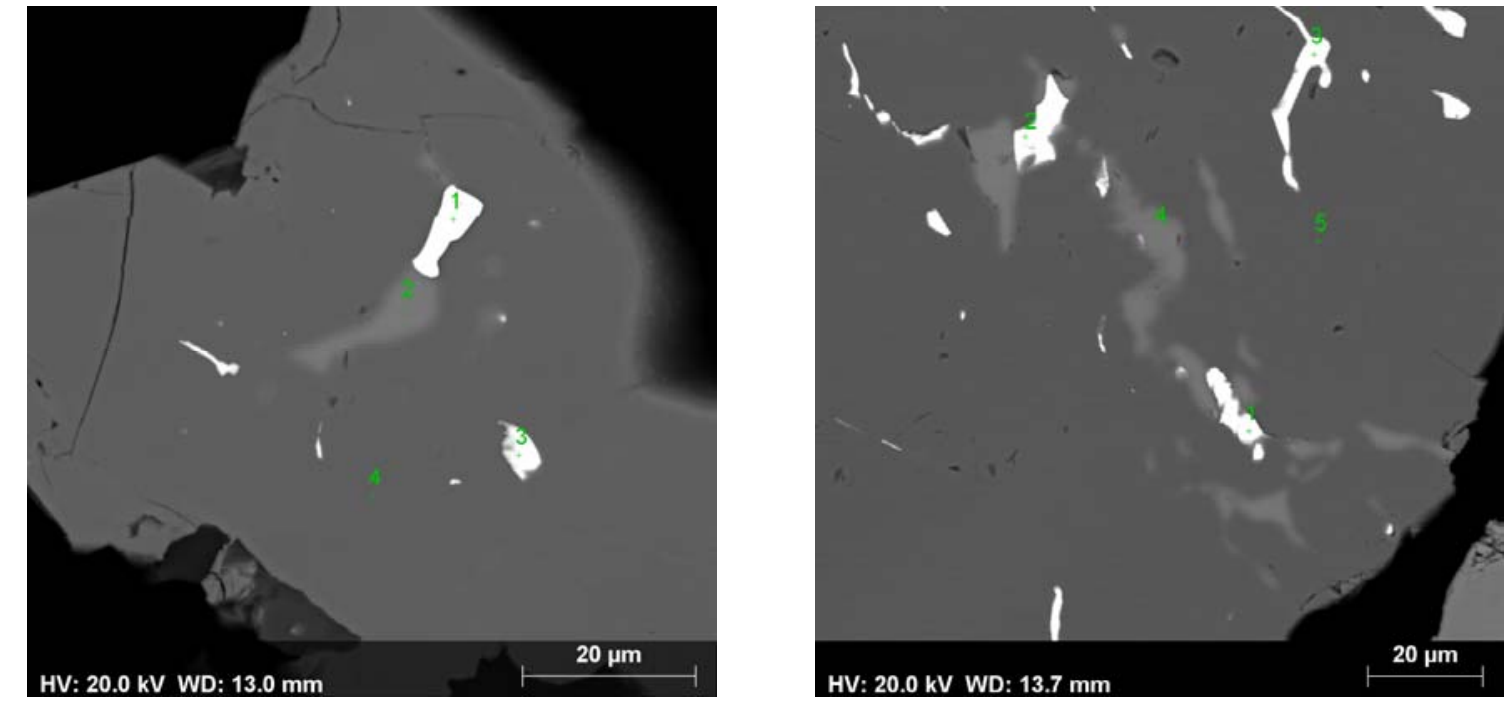

\begin{tabular}{ccccccc}
\hline & \multicolumn{6}{c}{ Teores (\% em massa) } \\
EDS & S & Fe & Zn & Ag & Au & Pb \\
\hline 1 & & & & 23,7 & 76,3 & \\
2 & 26,7 & 8,07 & 65,2 & & & \\
3 & 22,6 & & & & & 77,4 \\
4 & 47,3 & 52,7 & & & & \\
\hline
\end{tabular}

\begin{tabular}{crccccc}
\hline \multicolumn{7}{c}{ Teores (\% em massa) } \\
EDS & $\mathrm{S}$ & $\mathrm{Fe}$ & $\mathrm{Zn}$ & $\mathrm{Ag}$ & $\mathrm{Au}$ & $\mathrm{Pb}$ \\
\hline 1 & & & & 63,8 & 36,2 & \\
2 & 14,6 & & & & & 85,4 \\
3 & 13,3 & & & & & 86,7 \\
4 & 26,1 & 14,4 & 59,5 & & & \\
5 & 45,0 & 55,0 & & & & \\
\hline
\end{tabular}


APÊNCIDE 12 - Imagens de elétrons retroespalhados - Grãos de ouro inclusos
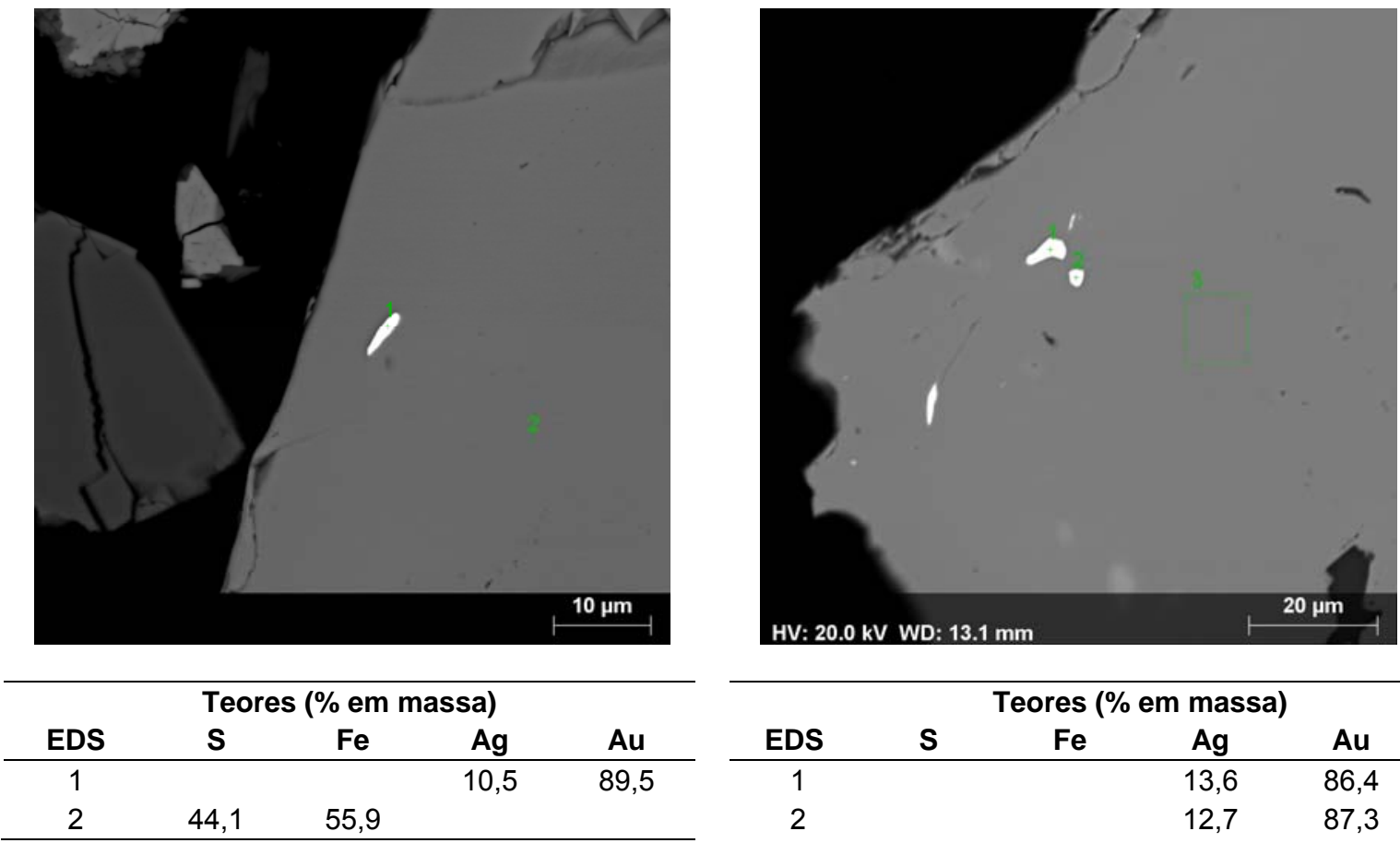

\begin{tabular}{ccccc}
\hline & & \multicolumn{3}{c}{ Teores (\% em massa) } \\
EDS & $\mathbf{S}$ & $\mathrm{Fe}$ & $\mathrm{Ag}$ & $\mathrm{Au}$ \\
\hline 1 & & & 13,6 & 86,4 \\
2 & & & 12,7 & 87,3 \\
3 & 44,1 & 55,9 & & \\
\hline
\end{tabular}
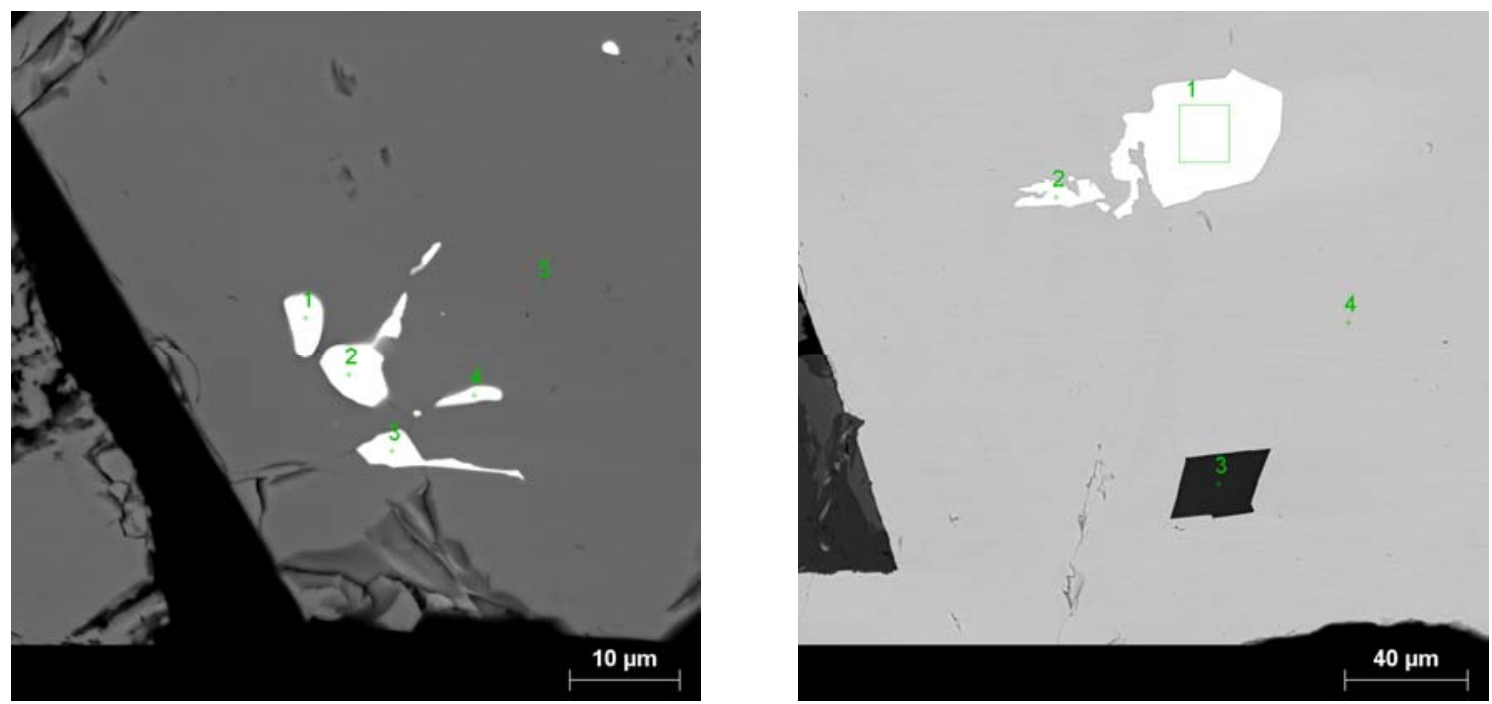

\begin{tabular}{cccccc}
\hline \multicolumn{6}{c}{ Teores (\% em massa) } \\
EDS & $\mathbf{S}$ & Fe & Ag & Au & Pb \\
\hline 1 & & & 11,1 & 88,9 & \\
2 & & & 8,23 & 91,8 & \\
3 & 13,5 & & & & 86,5 \\
4 & 20,3 & & & & 79,7 \\
5 & 46,6 & 53,4 & & & \\
\hline
\end{tabular}

\begin{tabular}{ccccccc}
\hline \multicolumn{7}{c}{ Teores (\% em massa) } \\
EDS & $\mathrm{SiO}_{2}$ & $\mathrm{~S}$ & $\mathrm{Fe}$ & $\mathrm{As}$ & $\mathrm{Ag}$ & $\mathrm{Au}$ \\
\hline 1 & & & & & 14,8 & 85,2 \\
2 & & & & & 13,7 & 86,3 \\
3 & 100,0 & & & & & \\
4 & & 18,7 & 40,2 & 41,1 & & \\
\hline
\end{tabular}

